IZA DP No. 5825

The Effect of Public Sector Employment on Women's Labour Market Outcomes

Brindusa Anghel

Sara de la Rica

Juan J. Dolado

June 2011 


\title{
The Effect of Public Sector Employment on Women's Labour Market Outcomes
}

\author{
Brindusa Anghel \\ FEDEA
}

\author{
Sara de la Rica \\ University of the Basque Country, \\ FEDEA and IZA \\ Juan J. Dolado \\ Universidad Carlos III, \\ CEPR and IZA
}

\section{Discussion Paper No. 5825 \\ June 2011}

IZA
P.O. Box 7240
53072 Bonn
Germany

Phone: +49-228-3894-0

Fax: +49-228-3894-180

E-mail: iza@iza.org

\begin{abstract}
Any opinions expressed here are those of the author(s) and not those of IZA. Research published in this series may include views on policy, but the institute itself takes no institutional policy positions.

The Institute for the Study of Labor (IZA) in Bonn is a local and virtual international research center and a place of communication between science, politics and business. IZA is an independent nonprofit organization supported by Deutsche Post Foundation. The center is associated with the University of Bonn and offers a stimulating research environment through its international network, workshops and conferences, data service, project support, research visits and doctoral program. IZA engages in (i) original and internationally competitive research in all fields of labor economics, (ii) development of policy concepts, and (iii) dissemination of research results and concepts to the interested public.
\end{abstract}

IZA Discussion Papers often represent preliminary work and are circulated to encourage discussion. Citation of such a paper should account for its provisional character. A revised version may be available directly from the author. 
IZA Discussion Paper No. 5825

June 2011

\section{ABSTRACT}

\section{The Effect of Public Sector Employment on Women's Labour Market Outcomes}

This paper addresses the role played by Public Sector (PS) employment across different OECD labour markets in explaining: (i) gender differences regarding choices to work in either PS or private sector, and (ii) subsequent changes in female labour market outcomes. To do so, we provide some empirical evidence about cross-country gender differences in choice of employment in the PS vs. the private sector, using the European Community Household Panel (ECHP), in the light of different theories on gender behaviour in the labour market. We also analyze the main determinants of the hourly wage gaps across these two sectors for males and females separately. Finally, we document the main stylized facts about labour market transitions by male and female workers among inactivity, unemployment, working in the PS and working in the private sector.

JEL Classification: J45, J16, J31

Keywords: $\quad$ public sector employment, gender gaps, labour market transitions

Corresponding author:

Sara de la Rica

University of the Basque Country

Facultad de Ciencias Económicas y Empresariales

Avenida Lehendakari Aguirre, 83

48015 Bilbao

Spain

E-mail: sara.delarica@ehu.es

\footnotetext{
* We are very grateful to Carolina Sánchez-Páramo (World Bank) and Angelica Salvidelpero (OECD) for very helpful comments and suggestions. Brindusa Anghel gratefully acknowledges the financial support provided by the Ministry of Science and Innovation (ECO2009-07530). Sara de la Rica acknowledges the financial support provided by the Ministry of Education (ECO2009-10818) and by the Basque Government (IT-241-07). Juan J. Dolado acknowledges the financial support from MCINN (Consolider-Ingenio 2010), Consejería de Educación de la Comunidad de Madrid (Excelecon) and Banco de España (Programa de Excelencia 2011).
} 


\section{INTRODUCTION}

Public Sector (PS, henceforth) employment accounts for about $20 \%$ of total employment on average in most OECD economies with this share being higher in Scandinavia (well above 30\%) and lower in Chile and Turkey (below 15\%). As shown in Figure 1, the PS employment share has declined over the last decade or so especially in those countries where it was initially larger, like in Scandinavia or Eastern Europe. The remaining economies exhibit more stable shares and it is only in Chile, Greece and The Netherlands that there has been a slight increase over time.

Figure 1. PS Employment as \% of Total Employment - Selected OECD Countries

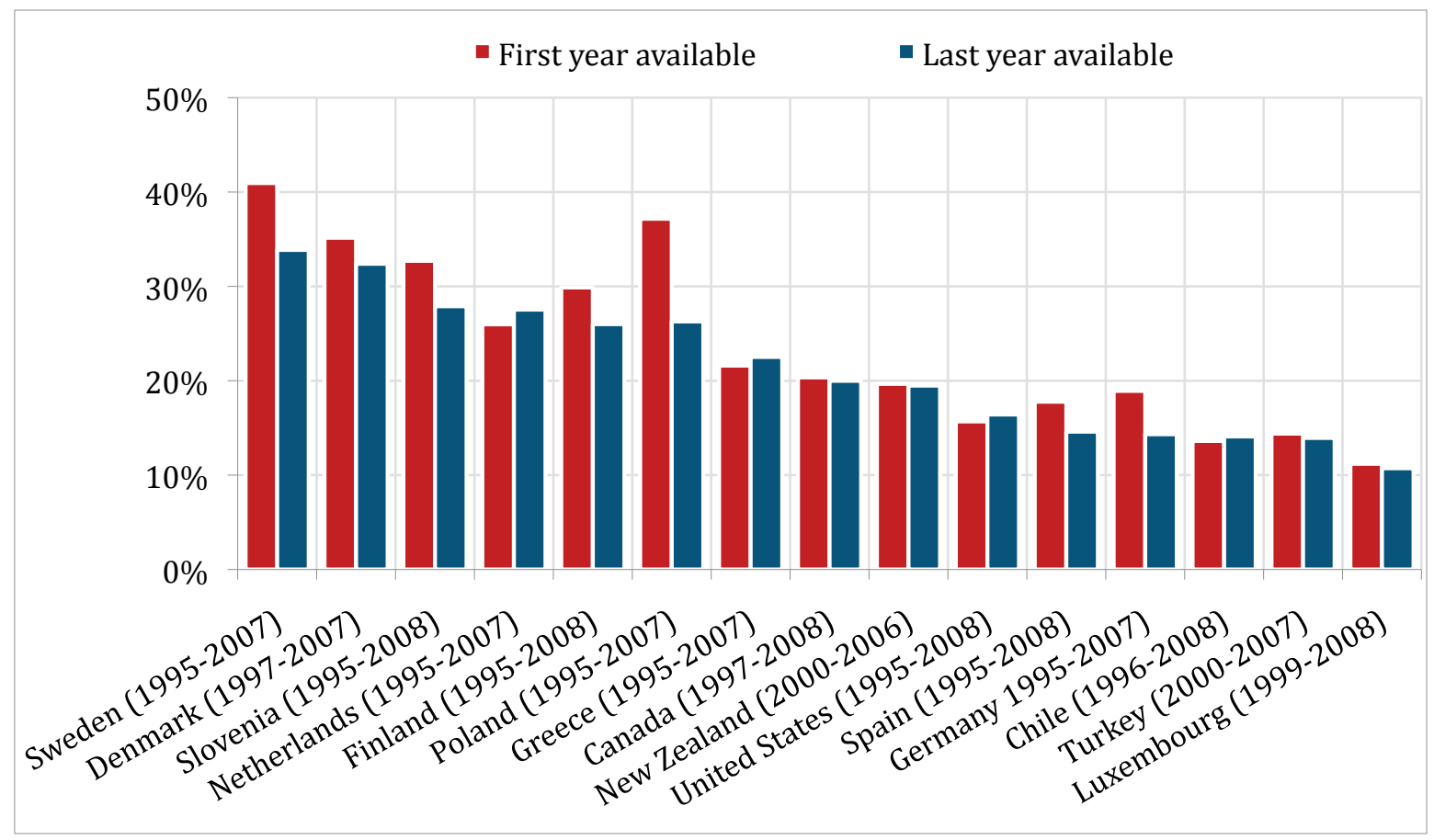

Source: ILO Laborsta

PS employment has been the subject of a wide range of studies starting from the eighties and early nineties (see, inter alia, Ehrenberg and Schwartz, 1986, Freeman, 1986, Freeman and Ichniowski, 1988, and Gunderson 1995) which have focused mainly on analyzing either earnings differentials between the public and private sectors or the impact of unionization on wages and employment in the PS. More recently, this focus has switched to examining differences in income mobility and income volatility between the two sectors in the UK (Postel-Vinay and Turon, 2007), as well as lifetime income differences, accounting for pensions and in-kind benefits (Danzer and Dolton, 2011). 
However, with the exceptions of Rosen (1996) and Gornick and Jacobs (1998), not much attention has been paid to study the relationship between PS employment and women's labour market outcomes. This is somewhat surprising since women tend to be clearly over-represented in PS jobs in a large majority of OECD countries. This is illustrated in Figure 2 where the female share in PS employment (first bar) is compared to the corresponding share in total employment (second bar) at the earliest and latest available dates in our dataset. As can be observed, in all countries but Turkey, the former share is quite higher that the latter. Interestingly, in those countries - like Canada, New Zealand and the Nordic ones - where the overall female share is close to $50 \%$, the overrepresentation of females in the PS is also largest - over 65\% in most cases. Further, this feature seems to be quite persistent over the analyzed period despite a general increase in female labour market participation in most countries. Thus, the first stylized fact to highlight is the positive correlation between the size of the PS and its female share in employment.

Figure 2. Female Share in Total Employment and in PS Employment - Selected OECD Countries

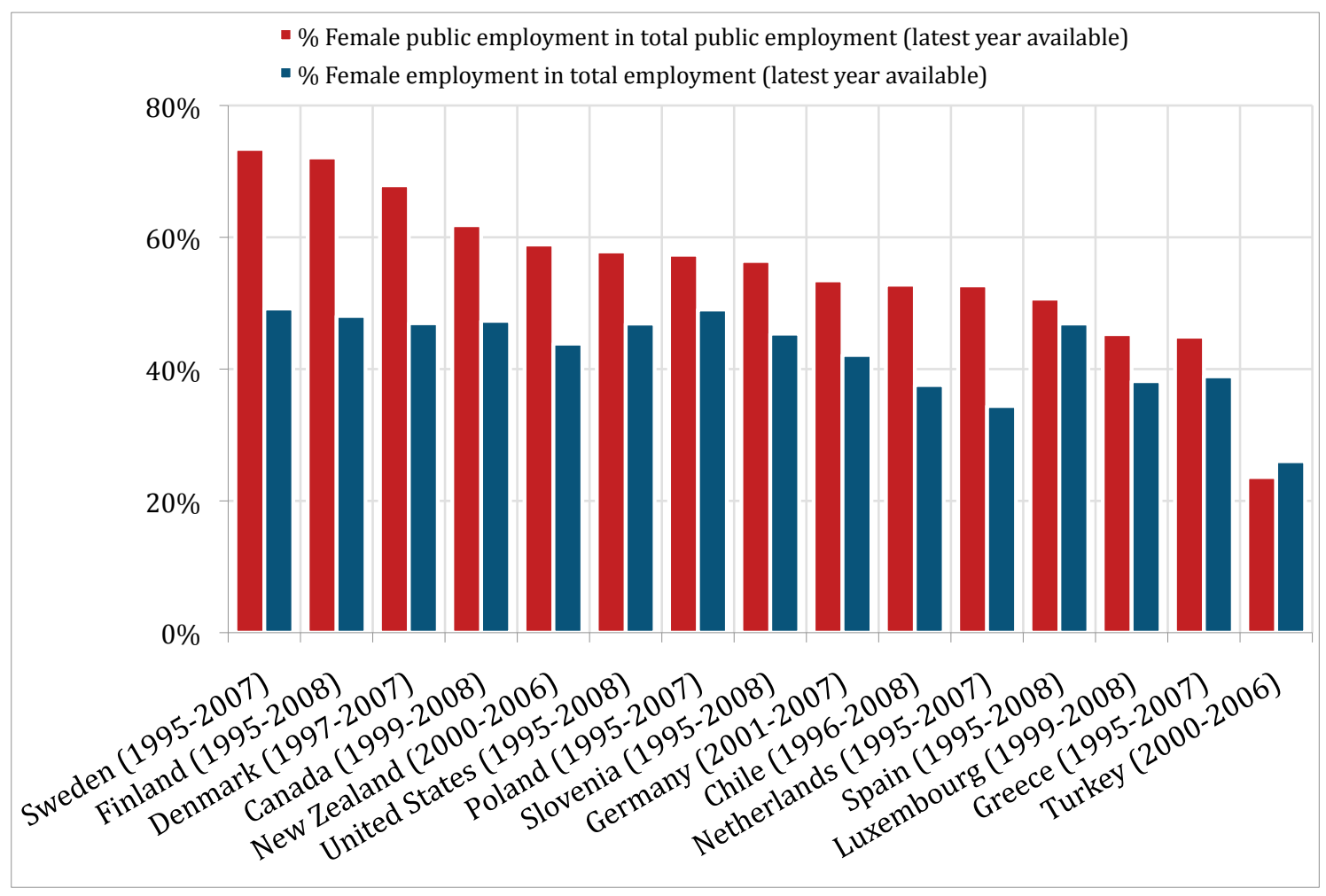

Source: ILO Laborsta

Although there have been many studies devoted to PS employment in specific countries, we are not aware of any research work that specifically addresses, across different OECD labour markets, the role played by PS employment in explaining, on the one hand, gender differences in preferences to work in either sector and, on the other, the subsequent changes in the female labour market outcomes. 
Our goal in this paper is to fill this gap. To do so, in Section 2 we lay out the main implications of some relevant theories characterizing the decision to work in the PS $v$ s. private sector which may result in: (i) different incidence of men and women in PS jobs, and (ii) different outcomes, in terms of wages, for men and women who work in either sector. Section 3 provides some aggregate evidence on time trends in female PS employment, as well as some motivation for further analysis based on the observed cross-country correlations among this type of employment and other related variables, such as educational attainment, gender wage gaps, fertility, etc. In Section 4 we provide some empirical evidence about gender differences in the choice of working in the PS vs. the private sector, once sample selection bias is controlled for. The first part of this section provides a descriptive analysis of the main demographic and labour market characteristics of men and women working in these two sectors based on the European Community Household Panel (ECHP), which is the more appropriate database for our cross-country comparisons. ${ }^{1}$ More precisely, we start reporting descriptive statistics about the incidence by gender of PS employment across industries, occupations and educational levels for each of the countries included in ECHP. Next, we discuss the estimated effects of the determinants of the relative probability of working in the PS vs. the private sector controlling for sample selection bias in labour market participation. This exercise is performed separately by gender in order to achieve a more precise understanding of the more relevant factors explaining men's and women's job choices. In Section 5, we estimate wage gaps across sectors (public vs. private) for males and females separately to analyze which factors help explain these gaps. Section 6 documents the labour market transitions by male and female workers between inactivity, unemployment, working in the PS and working in the private sector. Finally, Section 7 draws some conclusions.

\section{A MENU OF THEORIES OF SELECTION INTO PUBLIC SECTOR JOBS - GENDER DIFFERENCES AND ITS IMPLICATIONS}

\section{A. Statistical discrimination}

It is quite plausible that, in those countries where female labour force participation (FLFP) rates are lower, information among employers about female labour productivity is more imprecise. This would lead to statistical discrimination against women. In this respect, fostering female PS employment, often through open competitions, may offset this (asymmetric information) induced-

\footnotetext{
${ }^{1}$ Unfortunately, the EU-SILC, which is the follow up to the ECHP, does not provide separate information about public and private sectors.
} 
market failure by providing a relevant signalling device on female productivity, facilitating in this way women's efforts in making greater inroads into private sector jobs.

\section{B. Pecuniary conditions}

If women were to earn higher wages in the PS than in the private sector at all (or most of) stages of their professional careers - which seems to be the case in some countries possibly because of lower statistical or other forms of discrimination in the PS - this would provide a simple economic rationalization of why women are prevalent in the PS as well as to explain low female transitions from PS into the private sector.

\section{Compensating Differentials}

Even if private sector jobs were to pay higher wages, jobs in the PS may entail other nonpecuniary labour market conditions - like shorter hours of work, flexibility at the workplace, etc. which would lead women (more often than men) to prefer PS jobs. These conditions would facilitate conciliation of work and family lives. Further, if there were to be gender differences in attitudes toward risk (see, e.g., Nierderle and Vesterlund, 2007) women might prefer PS jobs because they often enjoy higher employment protection. Accordingly, even if women's earnings and promotion prospects in the PS were to be lower than in the private sector, the former may still provide higher overall utility than private sector jobs.

\section{Path dependence and Occupational Segregation}

If PS jobs tend to be female dominated, then younger women may end up working in the PS just because they prefer to work where older female cohorts did or because men dislike these jobs because of stigmatization. Two theories may explain the existence of this sort of path dependence: (i) men may avoid female jobs because they believe that they are stigmatised (in line with social exclusion theories á la Schelling, 1971) or, (ii) alternatively, women may avoid male-dominated jobs because they dislike (or perceive discrimination) competing with men (in line with theories on gender differences in the propensity to compete á la Gneezy et al., 2003). 


\section{STYLIZED FACTS - CORRELATIONS BETWEEN PUBLIC SECTOR EMPLOYMENT AND OTHER POSSIBLY RELATED VARIABLES ACROSS COUNTRIES.}

Unfortunately, PS data at the country level is relatively scarce. For example, the well-known OECD employment database only provides information related to jobs in "Public administration and defence" (PAD hereafter). However, this only accounts for a relatively small share of female PS employment, since women tend to be much more prevalent in some other (not reported) industries, such as public education or public health. Due to this limitation, our descriptive cross-country analysis will instead rely on data drawn from Laborsta which is a database compiled by the International Labour Organization (ILO) that provides much wider information on total PS employment, including those sectors omitted from the OECD dataset, yet for a shorter period (at most 14 years). ${ }^{2}$ Table 1 illustrates the gender distribution of PS employment by sectors of activity, highlighting those industries which are more representative in the PS (PAD, Education and Health and Social Work). PAD represents between $15 \%$ and $47 \%$ of the PS employment while Education and Health and Social Work account for 40-60\%. In almost all countries, between $20 \%$ and 55\% of women who are employed in the PS work in Education and a similar proportion do in Health and Social Work (except Luxembourg and US). Regarding men, the proportion of those employed in the PS who work in Education is similar to the female one, but they represent a much lower proportion than women, between $11 \%$ and $23 \%$, in Health and Social Work.

Table 1. Distribution of PS employment by main sectors of activity (latest available year)

\begin{tabular}{|c|c|c|c|c|c|c|c|c|c|c|c|c|}
\hline & \multicolumn{3}{|c|}{$\begin{array}{c}\text { Public Administration and } \\
\text { Defence }\end{array}$} & \multicolumn{3}{|c|}{ Education } & \multicolumn{3}{|c|}{ Health and Social Work } & \multicolumn{3}{|c|}{ Other sectors } \\
\hline & All & Women & Men & All & Women & Men & All & Women & Men & All & Women & Men \\
\hline Canada & $26.97 \%$ & $22.21 \%$ & $34.71 \%$ & $30.56 \%$ & $32.65 \%$ & $27.16 \%$ & $27.04 \%$ & $36.03 \%$ & $12.45 \%$ & $15.43 \%$ & $9.11 \%$ & $25.68 \%$ \\
\hline Denmark & $15.14 \%$ & $11.63 \%$ & $22.56 \%$ & $21.62 \%$ & $19.43 \%$ & $26.25 \%$ & $47.58 \%$ & $59.15 \%$ & $23.12 \%$ & $15.66 \%$ & $9.79 \%$ & $28.07 \%$ \\
\hline Finland & $16.97 \%$ & $13.15 \%$ & $26.74 \%$ & $20.72 \%$ & $19.42 \%$ & $24.06 \%$ & $42.79 \%$ & $54.49 \%$ & $12.83 \%$ & $19.52 \%$ & $12.94 \%$ & $36.36 \%$ \\
\hline Greece & $38.40 \%$ & $31.04 \%$ & $44.38 \%$ & $23.34 \%$ & $31.70 \%$ & $16.68 \%$ & $15.16 \%$ & $22.25 \%$ & $9.38 \%$ & $23.11 \%$ & $15.01 \%$ & $29.56 \%$ \\
\hline Luxembourg & $47.47 \%$ & $47.37 \%$ & $47.06 \%$ & $36.00 \%$ & $39.18 \%$ & $33.33 \%$ & $2.13 \%$ & $2.92 \%$ & $1.47 \%$ & $14.40 \%$ & $10.53 \%$ & $18.14 \%$ \\
\hline Netherlands & $23.65 \%$ & $13.63 \%$ & $34.88 \%$ & $21.82 \%$ & $21.85 \%$ & $21.80 \%$ & $40.12 \%$ & $57.47 \%$ & $20.72 \%$ & $14.40 \%$ & $7.06 \%$ & $22.60 \%$ \\
\hline New Zealand & $28.41 \%$ & $24.78 \%$ & $33.39 \%$ & $30.47 \%$ & $34.16 \%$ & $25.39 \%$ & $18.64 \%$ & $25.12 \%$ & $9.66 \%$ & $22.48 \%$ & $15.94 \%$ & $31.55 \%$ \\
\hline Poland & $24.71 \%$ & $20.55 \%$ & $30.09 \%$ & $26.47 \%$ & $36.29 \%$ & $13.78 \%$ & $15.16 \%$ & $22.01 \%$ & $6.30 \%$ & $33.66 \%$ & $21.15 \%$ & $49.84 \%$ \\
\hline Slovenia & $21.36 \%$ & $18.82 \%$ & $25.00 \%$ & $24.37 \%$ & $33.12 \%$ & $11.83 \%$ & $18.53 \%$ & $26.01 \%$ & $7.82 \%$ & $35.74 \%$ & $22.05 \%$ & $55.35 \%$ \\
\hline Spain & $42.00 \%$ & $32.09 \%$ & $53.39 \%$ & $24.58 \%$ & $28.75 \%$ & $19.78 \%$ & $22.41 \%$ & $31.74 \%$ & $11.68 \%$ & $11.01 \%$ & $7.41 \%$ & $15.16 \%$ \\
\hline Turkey & $40.58 \%$ & $20.76 \%$ & $46.70 \%$ & $24.15 \%$ & $39.41 \%$ & $19.38 \%$ & $13.65 \%$ & $27.63 \%$ & $9.32 \%$ & $21.63 \%$ & $12.20 \%$ & $24.59 \%$ \\
\hline United States & $42.23 \%$ & $33.49 \%$ & $53.98 \%$ & $46.38 \%$ & $55.53 \%$ & $34.06 \%$ & $5.78 \%$ & $7.39 \%$ & $3.63 \%$ & $5.61 \%$ & $3.59 \%$ & $8.33 \%$ \\
\hline
\end{tabular}

Source: ILO Laborsta

\footnotetext{
2 At any rate, we have checked (available upon request) that the trends followed by PS employment according to both the OECD and the definition adopted in this paper are quite similar in spite of being different in absolute magnitudes given the different definitions of PS in each database.
} 
As a motivation device, we start by presenting some stylized facts regarding cross-country correlations between female share in PS employment (FPSE) and a variety of labour market outcomes, admittedly endogenously determined, which include overall labour market participation, size of PS, educational attainment and occupational segregation. Later, the use of micro data will allow us to address some of the serious shortcomings that arise in providing causal interpretations of these correlations. Additionally, we provide some information about the degree of gender segregation in each of the two sectors.

\section{Labour Force Participation and Public Sector Employment Share: Differences by}

\section{Gender}

Figure 3 displays a very strong positive correlation between female LFP (FLFP) and FPSE. This merely descriptive evidence clearly confirms that those countries where the presence of women in the labour market is higher are those where the incidence of females in PS employment is also higher. Interestingly, such positive correlation is much weaker for men, basically because male labour force participation (MLFP) seems to be very stable in almost all countries (between 80 and 90\%) irrespectively of the male share in PS employment. Although we avoid making causal interpretations from these correlations, one could conjecture that this preliminary evidence might be consistent with Hypothesis (a), whereby higher FPSE decreases statistical discrimination against women through a better signalling of their true labour productivity. This in turn may help them to improve subsequently their access to jobs in the private sector. 
Figure 3. Labour force participation and PS employment share (males and females)

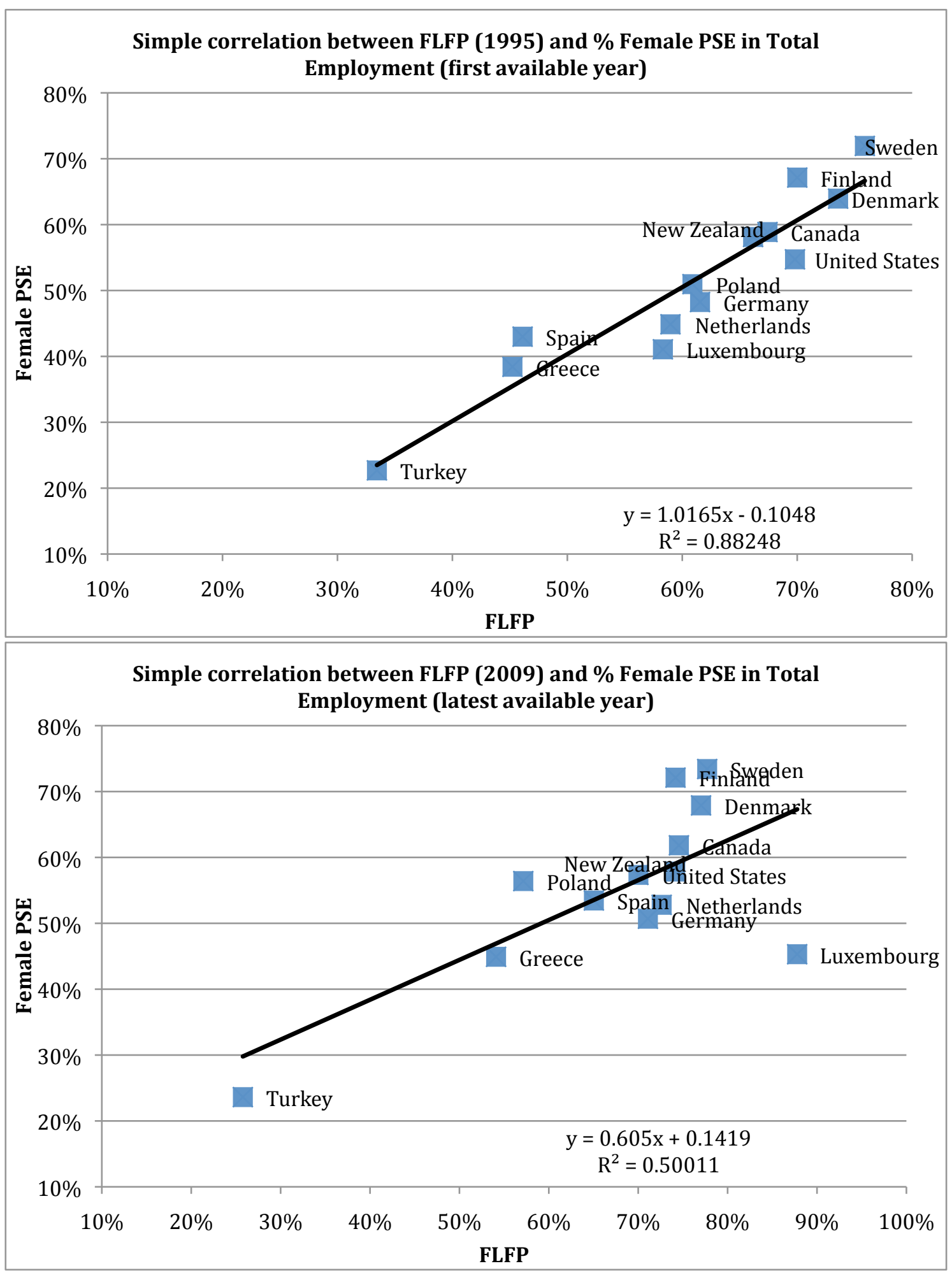



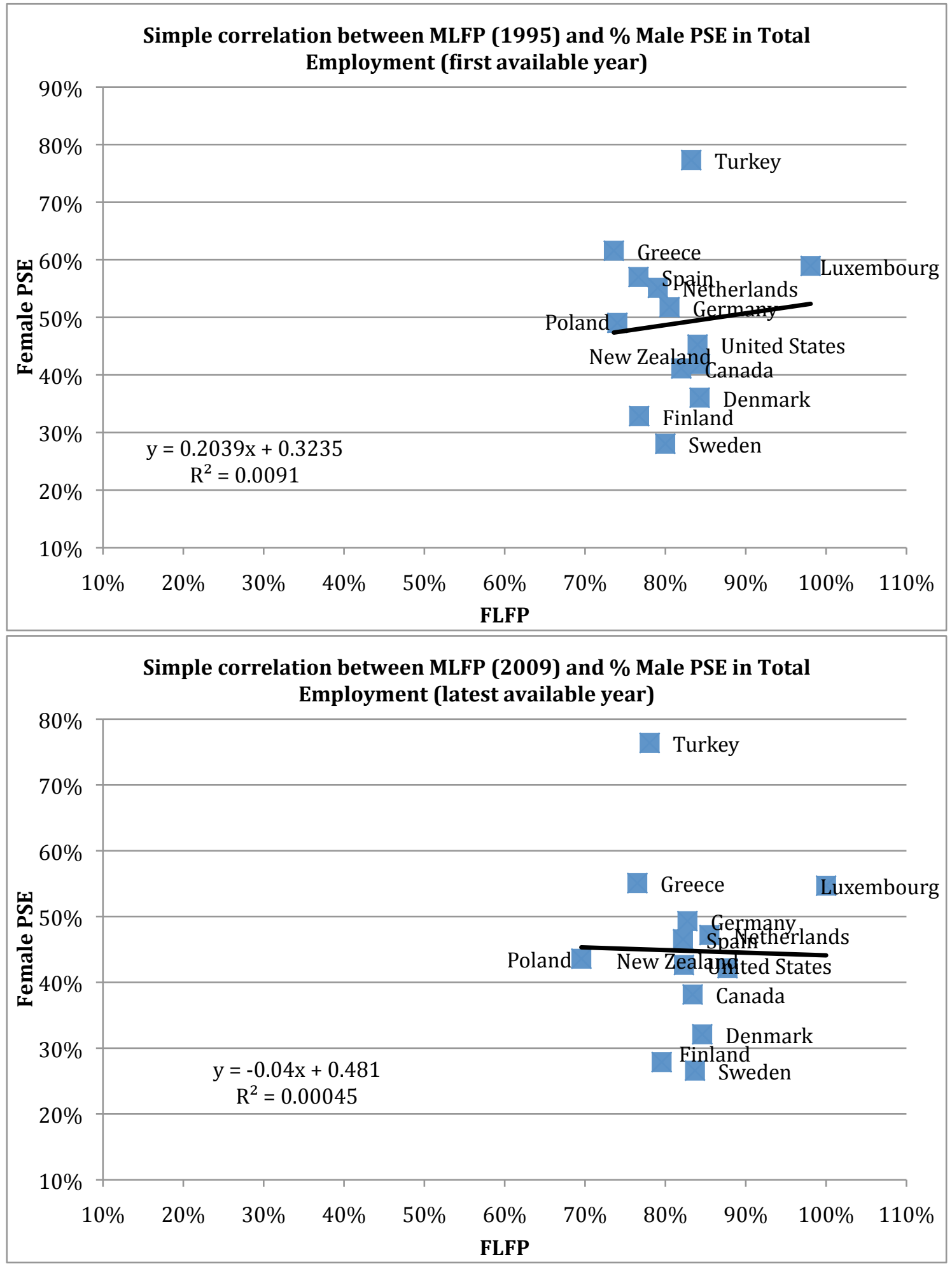

Source: OECD and ILO-Laborsta

\section{Female Public Sector Employment and Public Sector Employment Size}

Do countries with higher FPSE have larger PS employment (relative to the private sector)? According to Figure 4, the answer is definitely yes: women are disproportionately concentrated in the PS in countries where PS employment is high. However, this correlation (not reported) barely 
exists for males. In principle, this preliminary evidence could be interpreted as being consistent with Hypotheses (b), (c) and (d) if either women choose PS jobs for pecuniary or non-pecuniary reasons or, alternatively, because they prefer to work in female-dominated occupations as those provided by the PS.

Figure 4. Correlation between FPSE and total incidence of PS employment

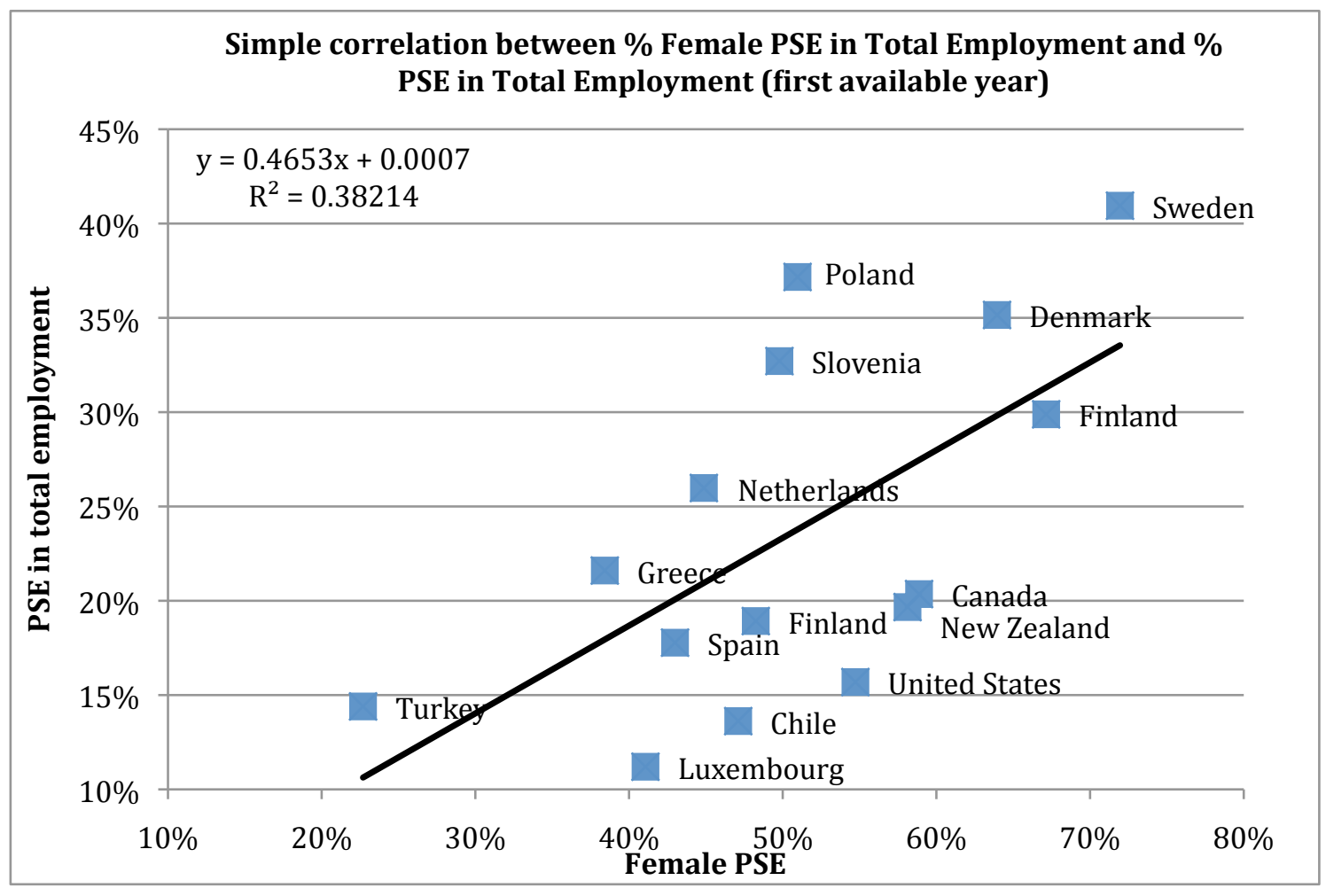




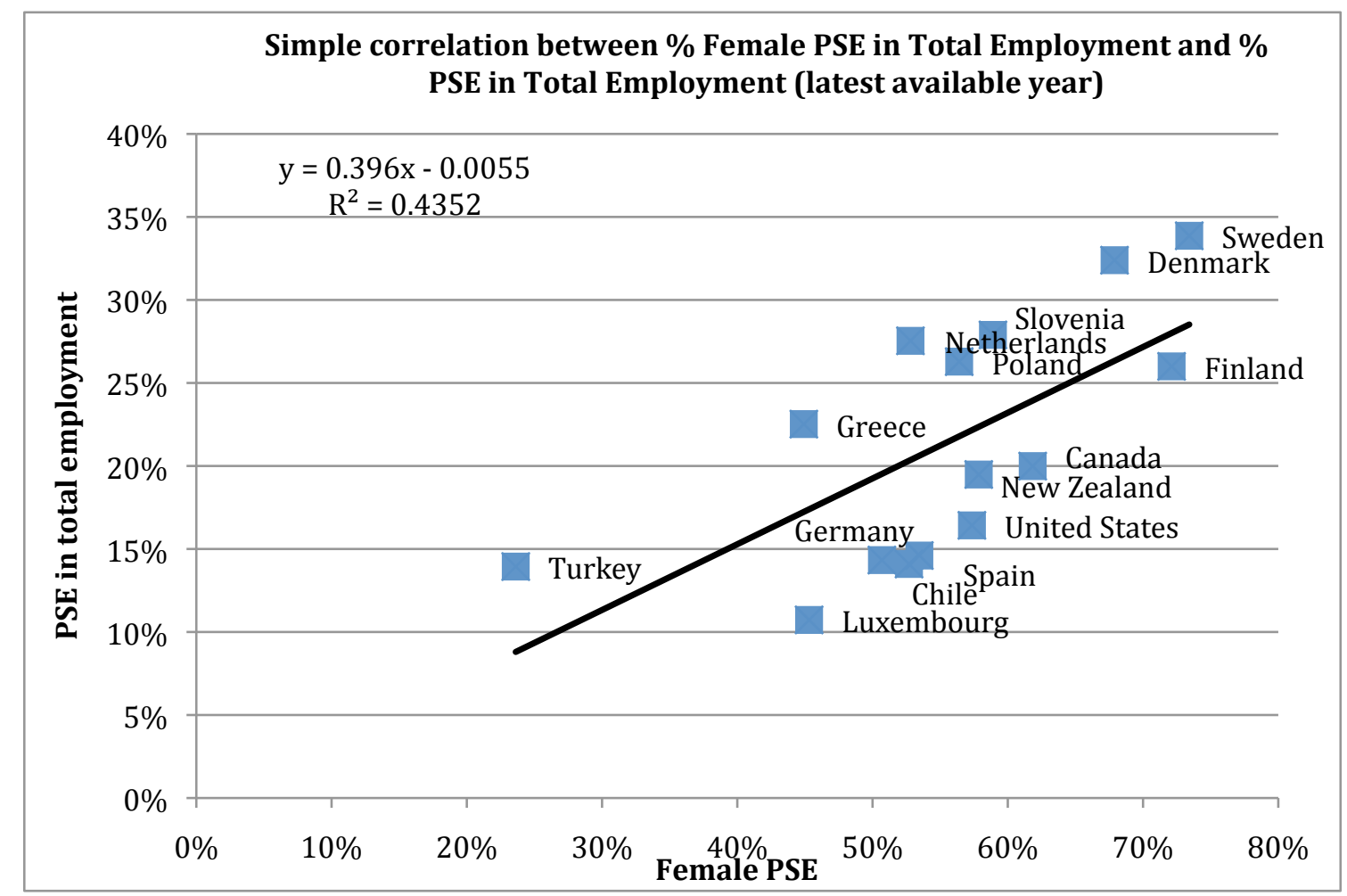

Source: Laborsta (ILO)

\section{Female Public Sector Employment and Educational Attainment}

Figure 5 documents an interesting finding: whereas, for women, the higher their educational attainment the higher their share in PS employment (which seems to suggest that this sector attracts higher-educated females), we observe the opposite correlation for males, namely, that the private sector is the one that attracts the higher-educated men. We will try later on to address potential explanations for both stylized facts by analyzing the determinants of the decision to work in the PS, relative to working in the private sector, and how they differ by gender. 
Figure 5. Correlations between FPSE and Educational Attainment - Females and Males (Latest year available)
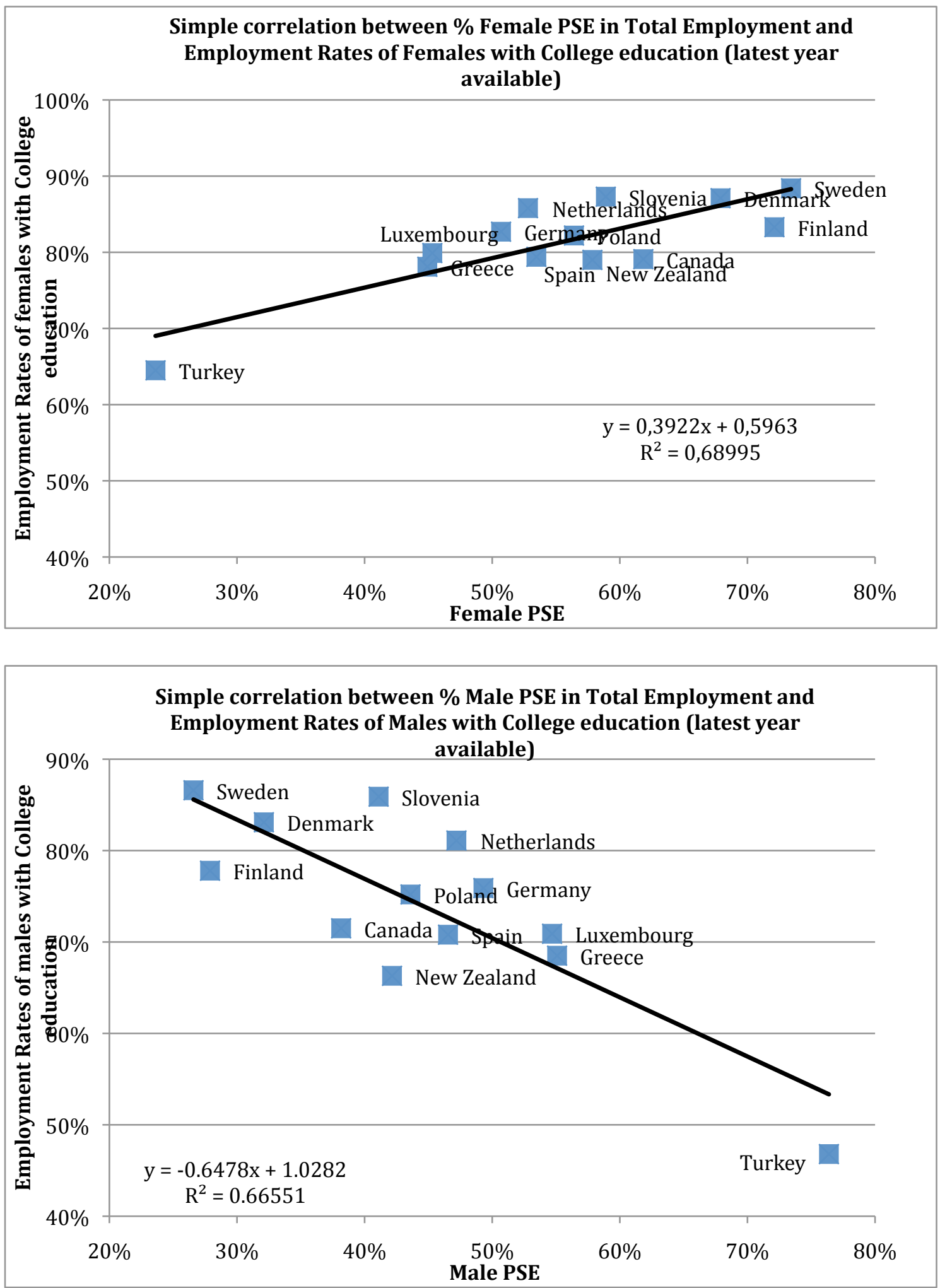

Source: Laborsta (ILO) and OECD Family Database. Notes: 1. For employment rates of females with college education, the latest available year is 2008. 2. For FPSE, latest available year is: 2008 for Canada, Finland, Spain and United States, 2007 for Denmark, Germany, Netherlands, Poland and Sweden and 2006 for New Zealand. 


\section{Female Public Sector Employment and Flexibility at the Workplace}

It is often argued that one of the main reasons behind women's preferences (relative to men) for PS jobs is to better reconcile family and work lives, particularly in those countries where the private sector does not provide enough flexibility to do so. To our knowledge, there are no indicators of flexibility at the workplace by country, which allow distinguishing between both sectors. As a result, we will only be able to use overall measures of flexibility. Figure 6 shows the correlations between two indicators of flexibility at the workplace and FPSE. The first one, which represents the share of women that report to be able to adjust their working schedules, exhibits a clear positive correlation with FPSE that would be consistent with Hypothesis (c). Yet, the second indicator, the share of part-time in total employment, reveals no correlation with FPSE possibly because in those countries where part-time jobs are more prevalent, like in the Netherlands, they tend be equally important in both sectors.

Figure 6. Correlation between FPSE and Work Time Schedule

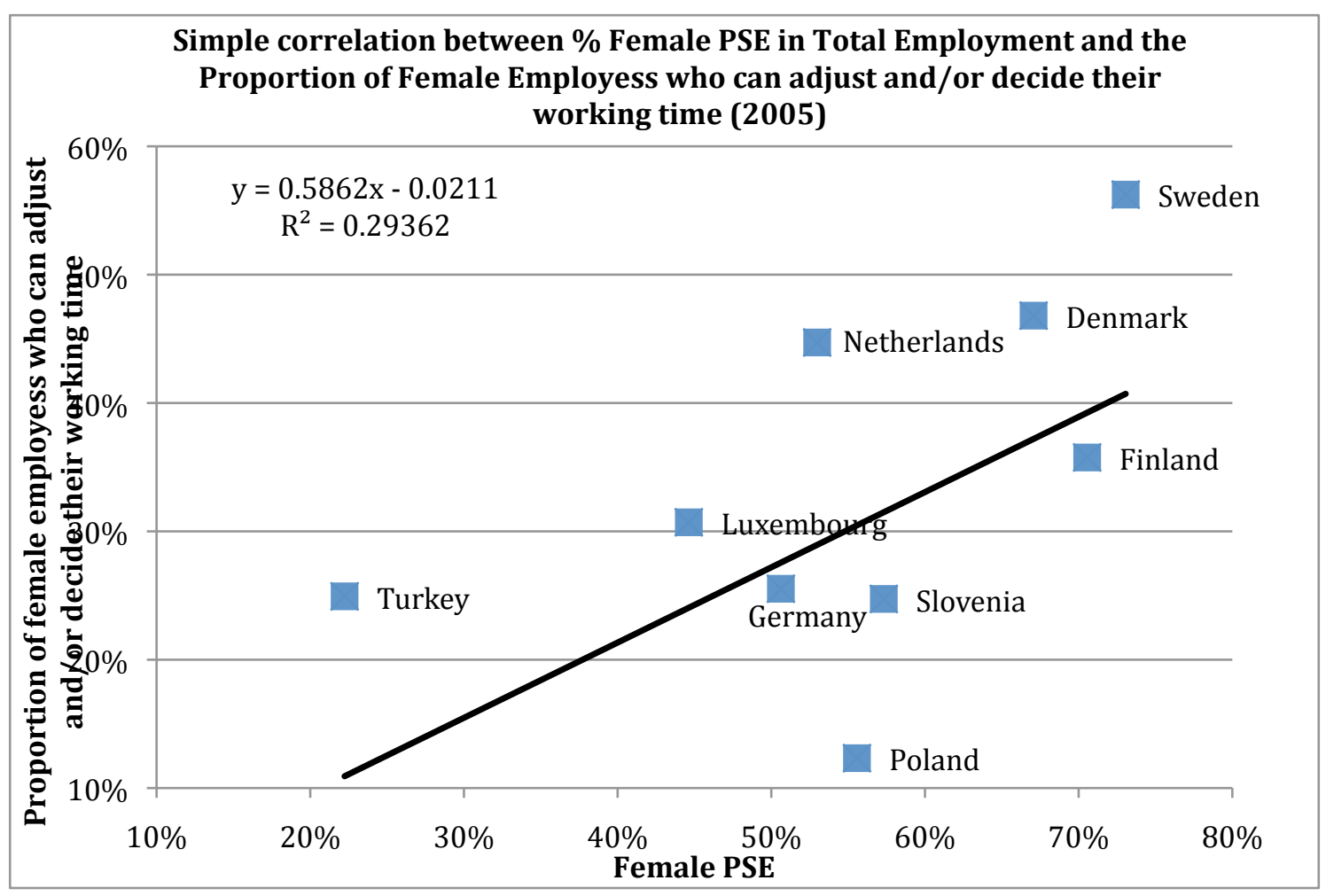




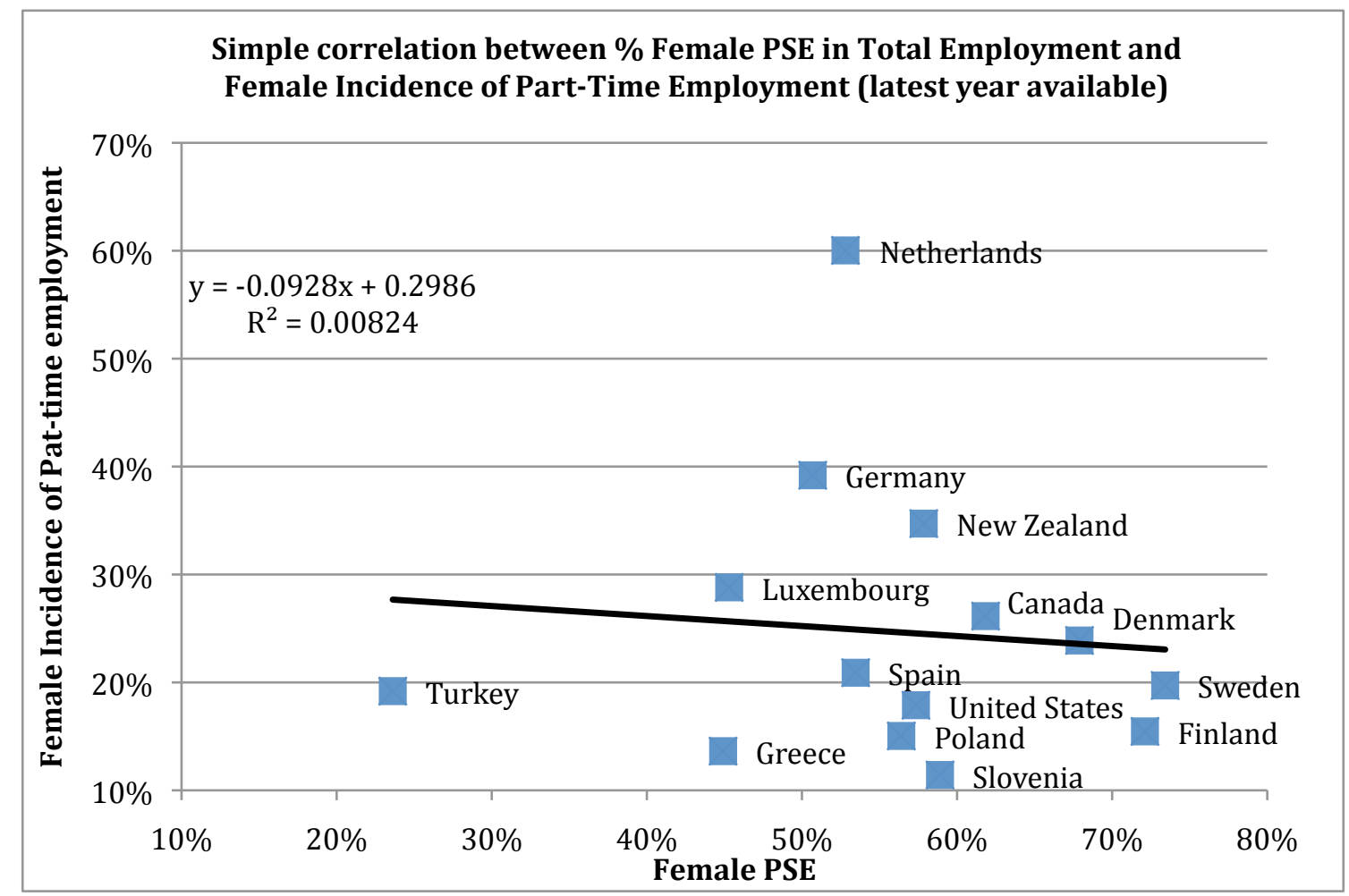

Source: Laborsta (ILO) and OECD Family Database. Notes: 1. For female incidence of part-time employment, the latest year available is 2008. 2. For FPSE, latest year available is: 2008 for Canada, Finland, Spain and United States, 2007 for Denmark, Germany, Netherlands, Poland and Sweden and 2006 for New Zealand

\section{Female Public Sector Employment and Fertility}

We next examine the issue of whether those countries with higher FPSE are also the ones where women can afford, from a labor market perspective, to have more kids. Childcare is very time intensive and one may think that PS jobs provide more flexibility that may be used to improve childcare. However, despite this belief, we do not observe any significant cross-country correlation between fertility rates and FPSE in Figure 7. 
Figure 7. Correlation between FPSE and Fertility Rates
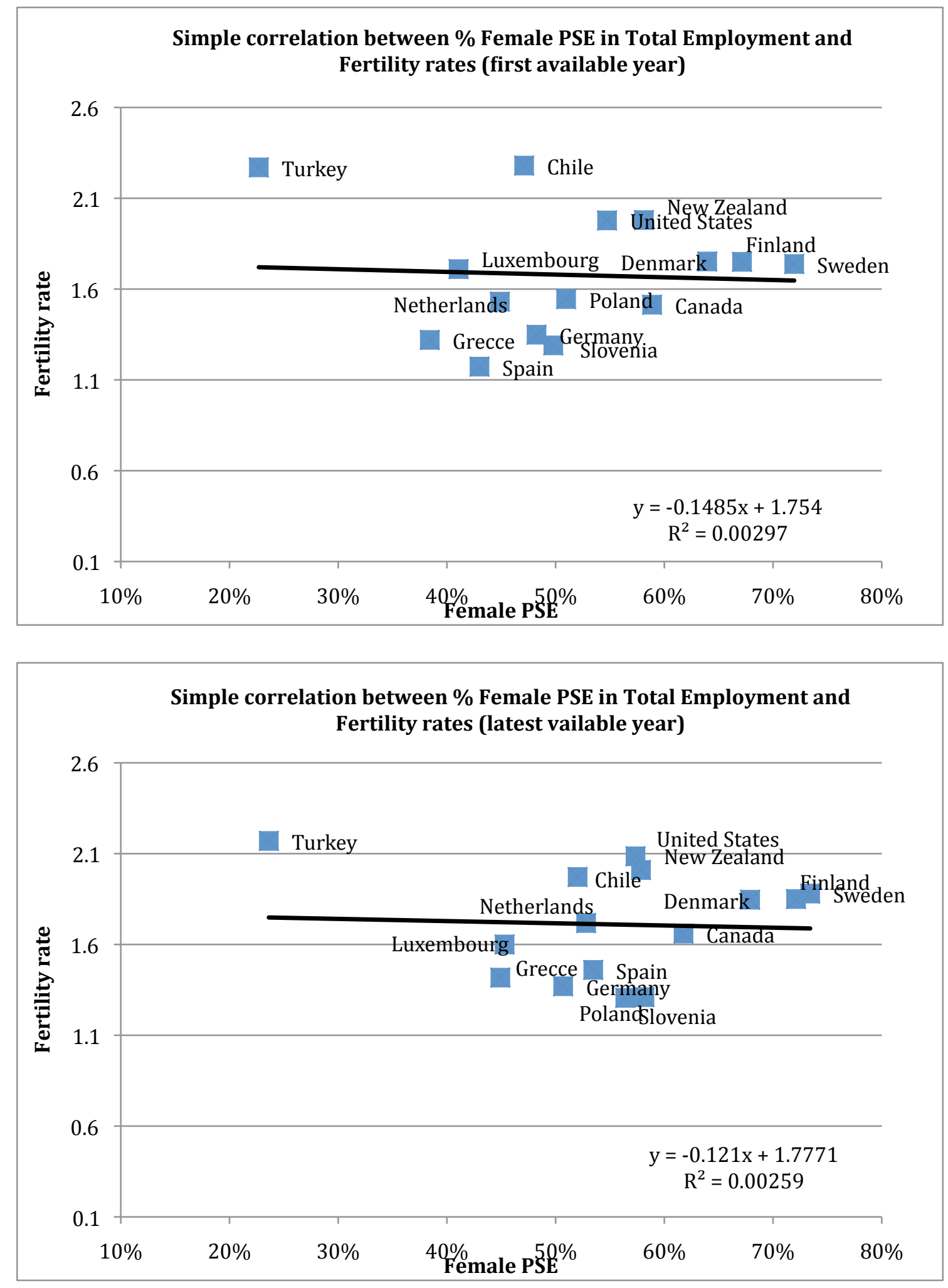

Source: Laborsta (ILO) and OECD Family Database 


\section{Female Public Sector Employment and Gender Wage Gaps}

Here, we address the issue of whether FPSE is related to the existing gender wage gaps in the two sectors. Figure 8 shows a positive correlation between the FPSE and the (raw) gender wage gap in the PS. The latter is taken from Eurostat Structure of Earnings Survey for 2008. This positive correlation may point out to the presence of glass ceilings in the public administration whereby the top and best-paid jobs are generally allocated to men. By contrast, we find a negative correlation between FPSE and the corresponding gender gap in the private sector. This last piece of evidence would again be consistent with Hypothesis (a) in the sense that a FPSE should help reducing statistical discrimination in the private sector and therefore in the gender wage gap.

Figure 8. Correlation between FPSE and Gender Pay Gaps

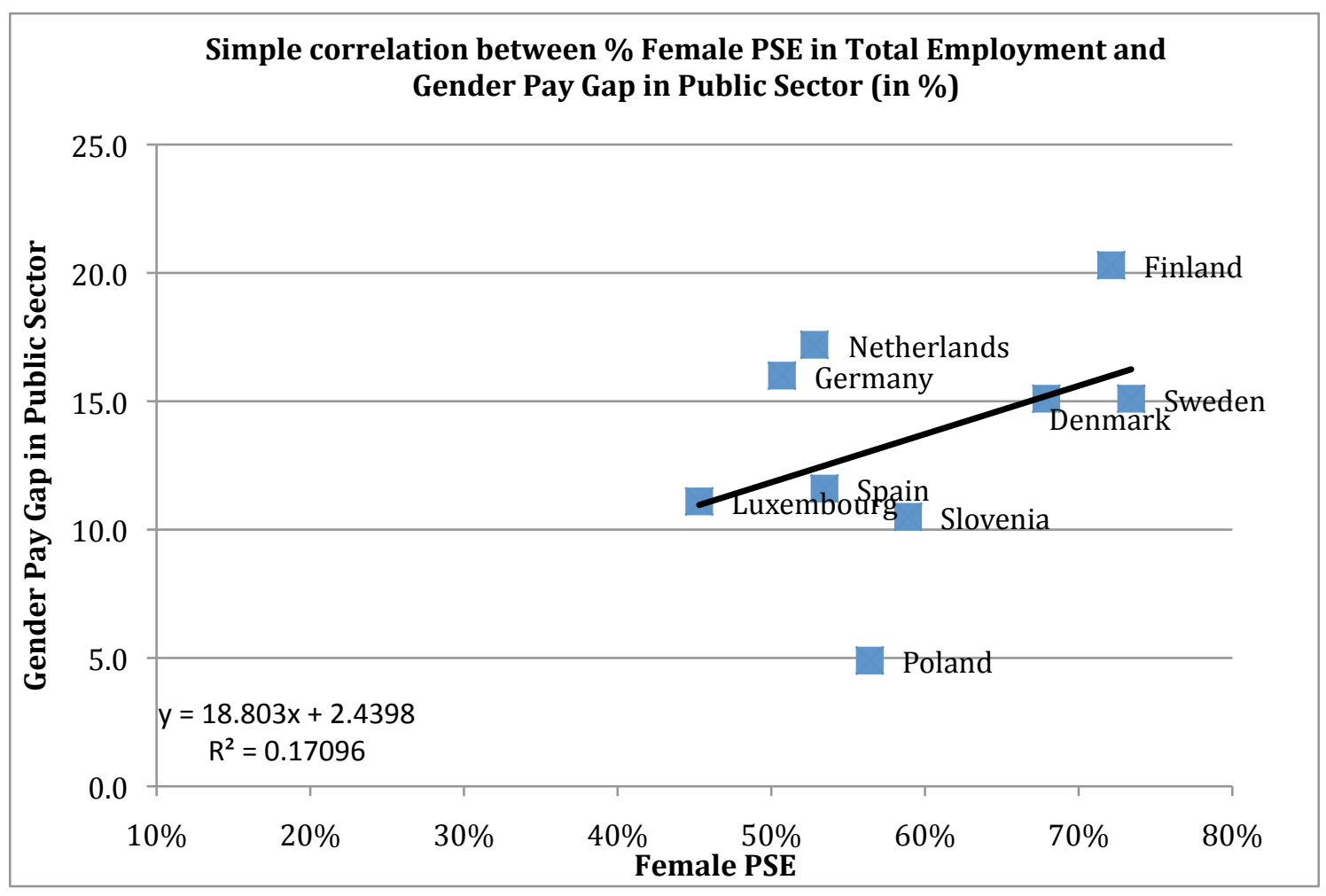




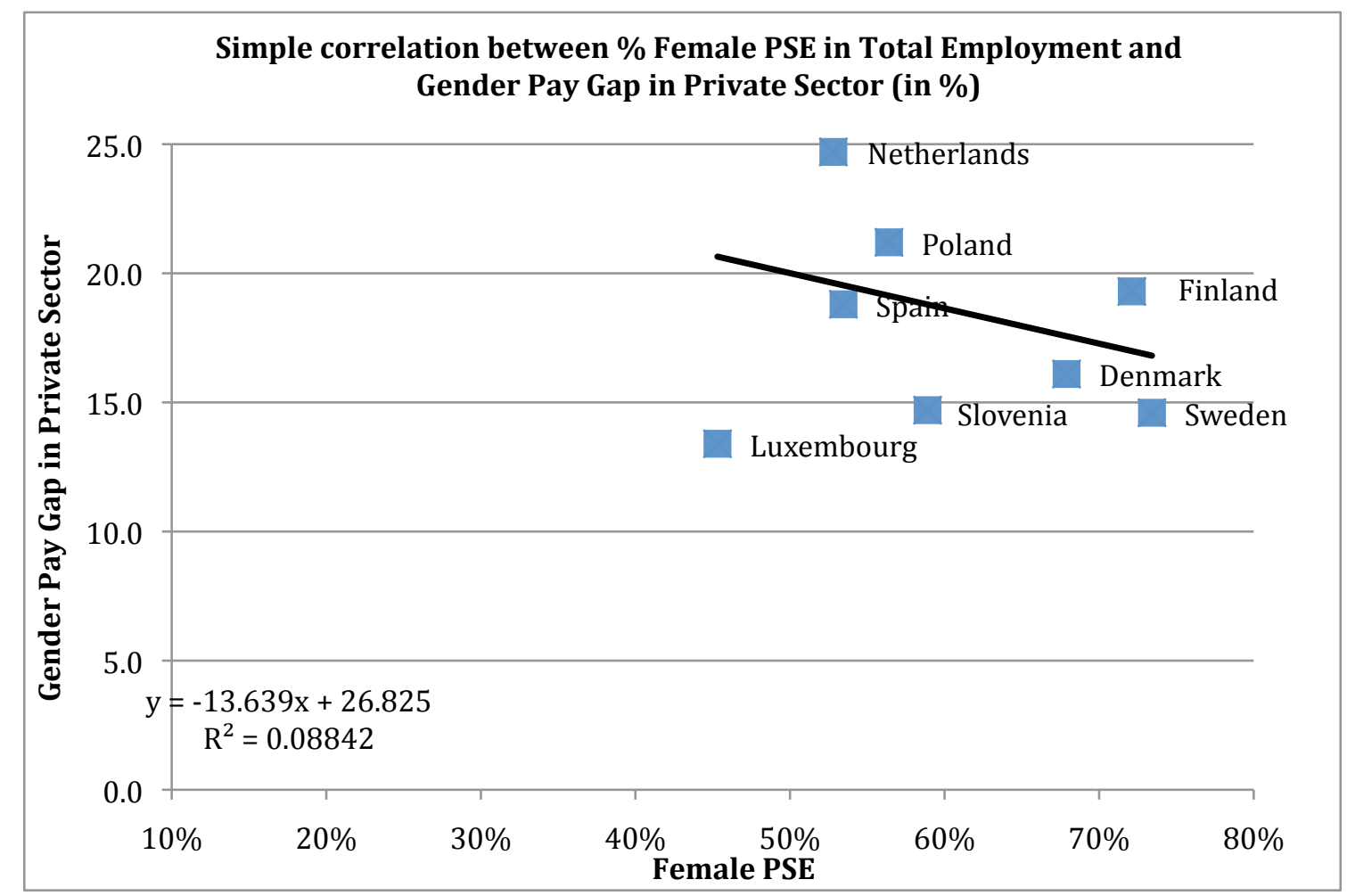

Source: Laborsta (ILO) and Eurostat

\section{Gender Segregation in the Public and Private Sectors}

Finally, we address the issue of whether gender occupational segregation differs across both sectors. To do so, we compute the well-known Duncan and Duncan (DD) segregation index for each of the 1-digit occupations available in the ECHP (see Section 4 for details). The results are for 1997 - a representative year in this sample. The DD index is defined as: $D D=0,5 \sum_{i}\left|m_{i}-f_{i}\right|$ where $m_{i}$ and $f_{i}$ are the average proportions of male (female) workers in occupation $i$. This index, expressed as a percent, can be loosely interpreted as the proportion of women (men) who have to "trade" occupations with a man (woman) for both sexes to be represented in all occupations in proportion to their representation in the whole sample. A value of $0 \%$ indicates that the distribution of men and women across occupations is the same, while a value of $100 \%$ indicates that women and men work in completely different occupations. The results are presented in Table 2 below and the main finding is that occupational segregation is much lower in the PS than in the private sector in most countries but Denmark, Greece, Italy and Portugal where the differences are smaller. All in all, this preliminary evidence seems to point out that PS employment tends to help women in getting the same jobs as men and, therefore, it goes against Hypothesis (d) in the PS. 
Table 2. Duncan \& Duncan Occupation Segregation Index (\%)

\begin{tabular}{|l|c|c|}
\hline & Public sector & Private sector \\
\hline Belgium & 17.89 & 33.06 \\
Denmark & 33.79 & 37.78 \\
France & 28.54 & 46.36 \\
Germany & 30.76 & 46.92 \\
Greece & 29.13 & 32.70 \\
Ireland & 28.62 & 40.23 \\
Italy & 30.58 & 32.81 \\
Netherlands & 29.70 & 37.10 \\
Portugal & 28.93 & 30.63 \\
Spain & 19.81 & 35.21 \\
UK & 17.60 & 40.57 \\
\hline \multicolumn{2}{|c|}{ Source: ECHP, own calculations }
\end{tabular}

\section{MICRO-LEVEL DESCRIPTIVE EVIDENCE ON GENDER DIFFERENCES IN PUBLIC VS. PRIVATE SECTOR EMPLOYMENT}

Given the data limitations of more recent cross-country databases (e.g. EU-SILC) for the purpose of our study, we use the ECHP for the micro-level analysis regarding gender differences in the relative choice between PS and private sector jobs. The ECHP is a survey based on a standardised questionnaire that involves annual interviewing of a representative panel of households and individuals in each country, covering a wide range of topics: income, health, education, housing, demographics and employment characteristics, etc. Its available time span is 8 years, running from 1994 to 2001. In the first wave (1994), a sample of some 60,500 nationally represented households i.e. approximately 130,000 adults aged 16 years and over - were interviewed in the then 12 member states. Hence, panel information at individual and country level is available for 8 years, 1994-2001, for the following 11 countries: Belgium, Denmark, France, Germany, Greece, Ireland, Italy, The Netherlands, Portugal, Spain and the UK, while in Sweden it is available only from 1997 onwards.

In the first part of this section, we present descriptive statistics for demographics such as average age, children, marital status and educational attainment that help us describe the individual characteristics of men and women that either work in the PS or in the private sector for each of the 12 countries in our sample. In addition, we present similar descriptive evidence on job characteristics - such as industry and occupational distribution of public and private sector jobs - and other labour-market related variables, such as weekly working hours, degree of satisfaction with 
labour conditions and wages, which may help us understand why women take jobs in different sectors than men in order to reconcile family duties and work life.

\subsection{Differences in workers' and job characteristics by gender - Public Sector vs. Private Sector}

Table 3 presents these demographic and job characteristics of individuals working in PS vs. private sector. For this description, we consider the central year of the panel (1997) as a representative one since very similar patterns hold for any other year in the sample.

\section{Demographics:}

Age: A very consistent result across all countries is that men and women who work in the PS are 2-3 years older on average than those working in the private sector.

Civil status (Married vs. Not married): Another common feature in our sample is that marriage rates among both men and women are higher in the PS than in the private sector (in Belgium and Netherlands, there are more married women in the private sector than in the PS, but the difference is very small). These differences in favour of the PS are particularly striking in the South-Mediterranean countries (Greece, Italy and Spain) as well as in Ireland.

Number of children: In general, women in the PS have more kids on average than those in the private sector. However, this result does not show up so clearly for males. For example, differences in this respect are negligible in Denmark, France, Greece, Sweden, the Netherlands, and UK.

\section{Educational Attainment:}

There are several interesting findings to be highlighted in this respect:

Educational attainment in the PS: Quite remarkable differences arise across countries regarding the proportion of individuals with tertiary education who work in either of the two sectors. For instance, less than 19\% of male and female workers in the PS have attained this educational attainment in Italy and Portugal. This starkly contrasts with other countries - such as Belgium, Denmark, Greece, Spain and UK - where more than $50 \%$ of women and more than $40 \%$ of men working in the PS have attained tertiary education. 
Gender differences in educational attainment of workers in PS: It can be observed that women in the PS are more educated than their male counterparts in countries like in Belgium, France, Italy, Portugal and Spain. However, the opposite result holds in Denmark, Sweden, The Netherlands and UK.

Differences in the educational attainment of workers in PS vs. Private Sector: For males, differences are very high in favour of the PS (more than $20 \%$ in countries like Denmark, Spain, Sweden UK, and The Netherlands, while they are smaller in Belgium, France, Italy and Portugal. For females, differences are very high in favour of PS (more than $20 \%$ ) in all countries, except in Italy and Portugal.

\section{Job Characteristics - Public vs. Private Jobs:}

Sector of activity: In most countries, the vast majority of PS employment is almost exclusively devoted to two Services sectors: (i) Education, health, social work and other community services and (ii) Public administration and defence. Yet, Transportation has also important PS coverage in some countries. By contrast, jobs in Trade, Hotels and Restaurants and Financial intermediation belong to the private sector in all countries.

Hours of work (weekly): We observe remarkable differences in the hours of work in the PS vs. private sector jobs across countries. For instance, for males, average weekly working time is around 7 hours longer in the private sector in Greece, and between 3-4 hours longer in Belgium, Ireland, Italy, Portugal, Spain and The Netherlands. These working time gaps are reduced to about 2 hours in Denmark, France and Germany while there is no difference in Sweden. Regarding women, average weekly working time is about 3-4 hours longer in the private sector in Italy, Portugal, Spain, while it is shorter (being negligible or at most one hour difference) in Belgium, Denmark, France, Sweden and UK.

Full-time/part-time: A common feature in most countries is that part-time is a female phenomenon. If we compare the part-time rates for females in PS vs. private sector, part-time is negligible in the PS in Portugal, Spain and UK, whereas it employs around $10-20 \%$ of females in Denmark, and France, Italy and Sweden. A well known outlier is the Netherlands, where about $45 \%$ of females work part-time, both in the PS and the private sector. 
Occupational Distribution of PS jobs: Given that we have documented that educational levels are in general higher in the PS than in the private sector, we should observe that PS Sector jobs are in general concentrated in the most qualified occupations. Indeed, this is the case. In all countries, but Italy and Portugal, the share of PS workers in occupational categories such as Professionals, Technicians and Clerks is much higher (in some cases twice) than the corresponding shares in the private sector.

Satisfaction with working conditions and environment: Although there is no data for all countries included in the ECHP on this issue, we can observe important disparities across those countries where that information is available. For instance, average satisfaction in PS is higher than in the private sector in France, Italy, Portugal and Spain. However, the opposite holds for other countries such as Belgium, Denmark and The Netherlands. These disparities might reveal important institutional differences across countries with regard to public and private sector working conditions.

Hourly Wages: Given that wages were still defined in 1997 in each country's own domestic currency (no euro yet), we report the ratio of public/private average hourly wages (both gross and net). Two important findings stand out from this comparison: (i) roughly speaking, all countries exhibit higher hourly wages in PS than in the private sector which at least can be partially attributed to the higher educational attainment of workers in PS, and (ii) there are large differences in the ratio public/private across countries. In this respect, there is a first group of countries (Greece, Ireland, Italy, Portugal and Spain) where hourly wages in the PS are at least twice higher than in the private sector. A second group of countries (France, Germany, The Netherlands and UK) exhibit ratios around between 1.3 and 1.5. Finally, average hourly wages in Denmark are very similar in both sectors. 
Table 3. Descriptive statistics of ECHP by country

\begin{tabular}{|c|c|c|c|c|c|c|c|c|c|c|c|c|c|c|c|c|c|c|c|c|c|c|c|c|}
\hline \multirow{4}{*}{ Demographics } & \multicolumn{8}{|c|}{ BELGIUM } & \multicolumn{8}{|c|}{ DENMARK } & \multicolumn{8}{|c|}{ FRANCE } \\
\hline & \multicolumn{4}{|c|}{$\begin{array}{l}\text { Public sector } \\
\end{array}$} & \multicolumn{4}{|c|}{ Private sector } & \multicolumn{4}{|c|}{ Public sector } & \multicolumn{4}{|c|}{ Private sector } & \multicolumn{4}{|c|}{ Public sector } & \multicolumn{4}{|c|}{ Private sector } \\
\hline & \multicolumn{2}{|c|}{ Men } & \multicolumn{2}{|c|}{ Women } & \multicolumn{2}{|c|}{ Men } & \multicolumn{2}{|c|}{ Women } & \multicolumn{2}{|c|}{ Men } & \multicolumn{2}{|c|}{ Women } & \multicolumn{2}{|c|}{ Men } & \multicolumn{2}{|c|}{ Women } & M & & Won & & $\mathrm{M}$ & & Won & nen \\
\hline & mean & sd & mean & sd & mean & sd & & sd & mean & & mean & sd & mean & sd & mean & & mean & & $\begin{array}{l}\text { mean } \\
\end{array}$ & & mean & $\mathrm{sd}$ & mean & sd \\
\hline Age & 40.81 & 8.62 & 39.19 & 8.77 & 38.68 & 9.05 & 36.78 & 8.70 & 41.19 & 10.23 & 40.37 & 9.53 & 38.45 & 10.27 & 38.12 & 10.56 & 40.65 & 9.16 & 40.85 & 9.42 & 38.29 & 9.97 & 37.33 & 9.73 \\
\hline Married & 0.71 & 0.45 & 0.65 & 0.48 & 0.71 & 0.46 & 0.66 & 0.47 & 0.58 & 0.49 & 0.60 & 0.49 & 0.55 & 0.50 & 0.56 & 0.50 & 0.67 & 0.47 & 0.58 & 0.49 & 0.60 & 0.49 & 0.57 & 0.50 \\
\hline No. of Children & 1.98 & 0.85 & 1.88 & 0.80 & 1.92 & 0.87 & 1.87 & 0.82 & 1.78 & 0.81 & 1.81 & 0.85 & 1.81 & 0.82 & 1.71 & 0.78 & 1.92 & 0.86 & 1.79 & 0.79 & 1.98 & 0.98 & 1.77 & 0.83 \\
\hline Sector of activity & & & & & & & & & & & & & & & & & & & & & & & & \\
\hline Industry $(\mathrm{E}+\mathrm{D}+\mathrm{F})$ & 0.07 & 0.25 & 0.01 & 0.09 & 0.50 & 0.50 & 0.21 & 0.41 & 0.06 & 0.23 & 0.01 & 0.07 & 0.50 & 0.50 & 0.29 & 0.45 & 0.09 & 0.28 & 0.02 & 0.14 & 0.52 & 0.50 & 0.26 & 0.44 \\
\hline Trade (G) & 0.00 & 0.05 & 0.01 & 0.09 & 0.12 & 0.32 & 0.15 & 0.36 & 0.00 & 0.00 & 0.01 & 0.07 & 0.17 & 0.37 & 0.23 & 0.42 & 0.01 & 0.11 & 0.00 & 0.06 & 0.18 & 0.38 & 0.22 & 0.42 \\
\hline Hotel and restaurants $(\mathrm{H})$ & 0.00 & 0.07 & 0.00 & 0.05 & 0.03 & 0.16 & 0.04 & 0.20 & 0.00 & 0.06 & 0.00 & 0.06 & 0.02 & 0.13 & 0.02 & 0.15 & 0.01 & 0.09 & 0.01 & 0.07 & 0.02 & 0.15 & 0.04 & 0.19 \\
\hline Transportation (I) & 0.18 & 0.39 & 0.03 & 0.16 & 0.06 & 0.24 & 0.01 & 0.10 & 0.11 & 0.32 & 0.04 & 0.19 & 0.07 & 0.26 & 0.04 & 0.21 & 0.15 & 0.36 & 0.05 & 0.22 & 0.07 & 0.26 & 0.02 & 0.15 \\
\hline $\begin{array}{l}\text { Financial intermediation, real estate and business } \\
(J+K)\end{array}$ & 0.03 & 0.17 & 0.03 & 0.17 & 0.14 & 0.35 & 0.15 & 0.36 & 0.06 & 0.23 & 0.03 & 0.18 & 0.16 & 0.37 & 0.20 & 0.40 & 0.06 & 0.23 & 0.04 & 0.20 & 0.15 & 0.35 & 0.18 & 0.38 \\
\hline $\begin{array}{l}\text { Education, health and social work and other } \\
\text { community services }(\mathrm{M}+\mathrm{N}+\mathrm{O}-\mathrm{Q})\end{array}$ & 0.39 & 0.49 & 0.77 & 0.42 & 0.14 & 0.35 & 0.42 & 0.49 & 0.47 & 0.50 & 0.73 & 0.45 & 0.07 & 0.26 & 0.20 & 0.40 & 0.31 & 0.46 & 0.63 & 0.48 & 0.06 & 0.24 & 0.26 & 0.44 \\
\hline Public administration and defense (L) & 0.32 & 0.47 & 0.16 & 0.37 & 0.01 & 0.10 & 0.02 & 0.14 & 0.30 & 0.46 & 0.19 & 0.39 & 0.01 & 0.09 & 0.01 & 0.09 & 0.38 & 0.48 & 0.25 & 0.43 & 0.00 & 0.06 & 0.02 & 0.14 \\
\hline Education & & & & & & & & & & & & & & & & & & & & & & & & \\
\hline Recognised third level education (ISCED 5-7) & 0.46 & 0.50 & 0.64 & 0.48 & 0.37 & 0.48 & 0.44 & 0.50 & 0.53 & 0.50 & 0.51 & 0.50 & 0.30 & 0.46 & 0.32 & 0.47 & 0.32 & 0.47 & 0.43 & 0.50 & 0.23 & 0.42 & 0.24 & 0.43 \\
\hline Second stage of secondary level education (ISCED 3) & 0.35 & 0.48 & 0.25 & 0.43 & 0.37 & 0.48 & 0.36 & 0.48 & 0.31 & 0.46 & 0.33 & 0.47 & 0.49 & 0.50 & 0.47 & 0.50 & 0.43 & 0.50 & 0.35 & 0.48 & 0.48 & 0.50 & 0.44 & 0.50 \\
\hline $\begin{array}{l}\text { Less than second stage of secondary education } \\
\text { (ISCED 0-2) }\end{array}$ & 0.20 & 0.40 & 0.12 & 0.32 & 0.26 & 0.44 & 0.21 & 0.40 & 0.16 & 0.37 & 0.16 & 0.37 & 0.21 & 0.41 & 0.21 & 0.41 & 0.25 & 0.43 & 0.22 & 0.41 & 0.30 & 0.46 & 0.31 & 0.46 \\
\hline Labour market & & & & & & & & & & & & & & & & & & & & & & & & \\
\hline Working hours & 41.58 & 8.99 & 34.88 & 9.59 & 45.76 & 11.17 & 36.53 & 11.89 & 39.92 & 7.62 & 35.10 & 6.82 & 41.84 & 9.55 & 36.03 & 8.61 & 39.56 & 9.87 & 34.80 & 9.77 & 42.73 & 8.64 & 35.82 & 9.21 \\
\hline Part-time & 0.03 & 0.17 & 0.23 & 0.42 & 0.01 & 0.11 & 0.23 & 0.42 & 0.02 & 0.15 & 0.14 & 0.35 & 0.02 & 0.13 & 0.15 & 0.36 & 0.04 & 0.19 & 0.15 & 0.36 & 0.02 & 0.14 & 0.19 & 0.40 \\
\hline Full time & 0.97 & 0.17 & 0.77 & 0.42 & 0.99 & 0.11 & 0.77 & 0.42 & 0.98 & 0.15 & 0.86 & 0.35 & 0.98 & 0.13 & 0.85 & 0.36 & 0.96 & 0.19 & 0.85 & 0.36 & 0.98 & 0.14 & 0.81 & 0.40 \\
\hline Satisfaction in terms of (1-minimum; 6-maximum): & & & & & & & & & & & & & & & & & & & & & & & & \\
\hline Working conditions/environment & 4.21 & 1.59 & 4.32 & 1.57 & 4.49 & 1.36 & 4.54 & 1.57 & 4.71 & 1.40 & 4.61 & 1.29 & 4.83 & 1.12 & 4.84 & 1.43 & 4.18 & 1.67 & 4.31 & 1.23 & 3.96 & 2.00 & 4.19 & 1.51 \\
\hline Occupation & & & & & & & & & & & & & & & & & & & & & & & & \\
\hline Legislators, senior officials and managers & 0.08 & 0.28 & 0.02 & 0.13 & 0.10 & 0.30 & 0.03 & 0.18 & 0.09 & 0.29 & 0.02 & 0.13 & 0.09 & 0.29 & 0.06 & 0.23 & 0.03 & 0.16 & 0.01 & 0.11 & 0.08 & 0.26 & 0.03 & 0.18 \\
\hline Professionals & 0.30 & 0.46 & 0.42 & 0.49 & 0.13 & 0.33 & 0.16 & 0.37 & 0.24 & 0.43 & 0.16 & 0.37 & 0.14 & 0.35 & 0.11 & 0.31 & 0.22 & 0.41 & 0.17 & 0.38 & 0.07 & 0.26 & 0.04 & 0.20 \\
\hline Technicians and associate professionals & 0.20 & 0.40 & 0.21 & 0.41 & 0.14 & 0.35 & 0.17 & 0.37 & 0.19 & 0.39 & 0.24 & 0.43 & 0.15 & 0.36 & 0.22 & 0.42 & 0.21 & 0.41 & 0.31 & 0.46 & 0.19 & 0.40 & 0.18 & 0.38 \\
\hline Clerks & 0.18 & 0.38 & 0.21 & 0.41 & 0.14 & 0.34 & 0.29 & 0.45 & 0.10 & 0.31 & 0.13 & 0.34 & 0.08 & 0.27 & 0.24 & 0.43 & 0.12 & 0.32 & 0.23 & 0.42 & 0.06 & 0.24 & 0.29 & 0.46 \\
\hline Service workers and shop and market sales workers & 0.05 & 0.23 & 0.07 & 0.26 & 0.10 & 0.30 & 0.20 & 0.40 & 0.15 & 0.36 & 0.38 & 0.49 & 0.04 & 0.19 & 0.13 & 0.34 & 0.10 & 0.30 & 0.16 & 0.37 & 0.05 & 0.22 & 0.24 & 0.42 \\
\hline Craft and related trade workers + skilled workers & 0.07 & 0.26 & 0.01 & 0.11 & 0.21 & 0.41 & 0.04 & 0.19 & 0.03 & 0.18 & 0.00 & 0.06 & 0.26 & 0.44 & 0.04 & 0.19 & 0.18 & 0.38 & 0.01 & 0.09 & 0.27 & 0.44 & 0.03 & 0.16 \\
\hline Plant and machine of & 0.05 & 0.21 & 0.00 & 0.06 & 0.10 & 0.30 & 0.02 & 0.13 & 0.06 & 0.24 & 0.00 & 0.06 & 0.15 & 0.35 & 0.08 & 0.28 & 0.07 & 0.26 & 0.00 & 0.07 & 0.22 & 0.42 & 0.09 & 0.29 \\
\hline Elementary occupations & 0.06 & 0.24 & 0.06 & 0.23 & 0.09 & 0.28 & 0.10 & 0.30 & 0.13 & 0.34 & 0.06 & 0.23 & 0.10 & 0.30 & 0.13 & 0.33 & 0.09 & 0.28 & 0.10 & 0.29 & 0.06 & 0.23 & 0.10 & 0.30 \\
\hline Hourly wages (ratio Public/Private) & Public/1 & rivate & Public/1 & ivate & & & & & Public// & rivate & Public/I & rivate & & & & & Public/1 & rivate & Public/P & 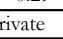 & & & & \\
\hline Gross & 1.30 & & 1.44 & & & & & & 1.02 & & 1.07 & & & & & & 1.26 & & 1.42 & & & & & \\
\hline Net & 1.36 & & 1.42 & & & & & & 1.05 & & 1.10 & & & & & & 1.25 & & 1.42 & & & & & \\
\hline Observations & 427 & & 493 & & 1032 & & 729 & & 145 & & 305 & & 497 & & 253 & & 715 & & 933 & & 1944 & & 1297 & \\
\hline
\end{tabular}




\section{Table 3 (cont.)}

\begin{tabular}{|c|c|c|c|c|c|c|c|c|c|c|c|c|c|c|c|c|c|c|c|c|c|c|c|c|}
\hline & \multicolumn{8}{|c|}{ GERMANY } & \multicolumn{8}{|c|}{ GREECE } & \multicolumn{8}{|c|}{ IRELAND } \\
\hline & \multicolumn{4}{|c|}{$\begin{array}{l}\text { Public sector } \\
\end{array}$} & \multicolumn{4}{|c|}{\begin{tabular}{|l|l} 
Private sector \\
\end{tabular}} & \multicolumn{4}{|c|}{$\begin{array}{l}\text { Public sector } \\
\end{array}$} & \multicolumn{4}{|c|}{\begin{tabular}{|l} 
Private sector \\
\end{tabular}} & \multicolumn{4}{|c|}{$\begin{array}{l}\text { Public sector } \\
\end{array}$} & \multicolumn{4}{|c|}{ Private sector } \\
\hline & \multicolumn{2}{|c|}{ Men } & \multicolumn{2}{|c|}{ Women } & \multicolumn{2}{|c|}{ Men } & \multicolumn{2}{|c|}{ Women } & \multicolumn{2}{|c|}{ Men } & \multicolumn{2}{|c|}{ Women } & \multicolumn{2}{|c|}{ Men } & \multicolumn{2}{|c|}{ Women } & \multicolumn{2}{|c|}{ Men } & & & M & & Won & men \\
\hline Demographics & mean & $\mathrm{sd}$ & mean & & mean & sd & mean & sd & mean & & mean & sd & mean & sd & mean & & mean & sd & mean & & mean & sd & mean & sd \\
\hline Age & 40.41 & 10.35 & 38.41 & 10.16 & 38.37 & 10.30 & 37.58 & 10.44 & 41.92 & 8.84 & 39.28 & 8.31 & 38.17 & 10.53 & 35.30 & 9.98 & 42.11 & 9.54 & 36.97 & 9.96 & 35.80 & 11.22 & 33.93 & 10.53 \\
\hline Married & 0.67 & 0.47 & 0.66 & 0.48 & 0.68 & 0.47 & 0.61 & 0.49 & 0.83 & 0.38 & 0.74 & 0.44 & 0.69 & 0.46 & 0.64 & 0.48 & 0.78 & 0.42 & 0.63 & 0.48 & 0.57 & 0.49 & 0.51 & 0.50 \\
\hline No. of Children & 1.83 & 1.00 & 1.66 & 0.70 & 1.77 & 0.82 & 1.62 & 0.70 & 1.86 & 0.72 & 1.79 & 0.71 & 1.87 & 0.75 & 1.78 & 0.74 & 2.65 & 1.31 & 2.32 & 1.10 & 2.52 & 1.28 & 2.21 & 1.13 \\
\hline Sector of activity & & & & & & & & & & & & & & & & & & & & & & & & \\
\hline Industry $(\mathrm{E}+\mathrm{D}+\mathrm{F})$ & 0.08 & 0.28 & 0.01 & 0.11 & 0.67 & 0.47 & 0.32 & 0.47 & 0.13 & 0.33 & 0.03 & 0.18 & 0.45 & 0.50 & 0.24 & 0.43 & 0.08 & 0.28 & 0.01 & 0.09 & 0.54 & 0.50 & 0.27 & 0.44 \\
\hline Trade (G) & 0.00 & 0.07 & 0.00 & 0.06 & 0.13 & 0.33 & 0.27 & 0.44 & 0.01 & 0.09 & 0.01 & 0.07 & 0.25 & 0.44 & 0.32 & 0.47 & 0.00 & 0.00 & 0.00 & 0.00 & 0.16 & 0.37 & 0.19 & 0.39 \\
\hline Hotel and restaurants $(\mathrm{H})$ & 0.00 & 0.00 & 0.00 & 0.00 & 0.02 & 0.14 & 0.04 & 0.20 & 0.00 & 0.00 & 0.00 & 0.05 & 0.08 & 0.27 & 0.10 & 0.31 & 0.00 & 0.00 & 0.00 & 0.05 & 0.04 & 0.19 & 0.10 & 0.31 \\
\hline Transportation (I) & 0.14 & 0.35 & 0.05 & 0.21 & 0.05 & 0.22 & 0.03 & 0.17 & 0.14 & 0.35 & 0.04 & 0.19 & 0.08 & 0.28 & 0.02 & 0.16 & 0.22 & 0.41 & 0.04 & 0.19 & 0.06 & 0.23 & 0.03 & 0.18 \\
\hline $\begin{array}{l}\text { Financial intermediation, real estate and business } \\
(1+K)\end{array}$ & 0.06 & 0.24 & 0.06 & 0.24 & 0.09 & 0.29 & 0.17 & 0.37 & 0.07 & 0.26 & 0.09 & 0.29 & 0.07 & 0.25 & 0.11 & 0.32 & 0.03 & 0.17 & 0.03 & 0.18 & 0.12 & 0.33 & 0.16 & 0.37 \\
\hline $\begin{array}{l}\text { Education, health and social work and other } \\
\text { community services }(M+N+O-Q)\end{array}$ & 0.32 & 0.47 & 0.62 & 0.49 & 0.04 & 0.20 & 0.17 & 0.37 & 0.27 & 0.44 & 0.60 & 0.49 & 0.06 & 0.23 & 0.19 & 0.39 & 0.31 & 0.46 & 0.74 & 0.44 & 0.08 & 0.27 & 0.24 & 0.43 \\
\hline Public administration and defense $(\mathrm{L})$ & 0.39 & 0.49 & 0.26 & 0.44 & 0.00 & 0.05 & 0.00 & 0.00 & 0.39 & 0.49 & 0.23 & 0.42 & 0.01 & 0.08 & 0.00 & 0.06 & 0.36 & 0.48 & 0.18 & 0.39 & 0.00 & 0.03 & 0.01 & 0.09 \\
\hline Education & & & & & & & & & & & & & & & & & & & & & & & & \\
\hline Recognised third level education (ISCED 5-7) & 0.34 & 0.48 & 0.32 & 0.47 & 0.23 & 0.42 & 0.15 & 0.36 & 0.42 & 0.49 & 0.59 & 0.49 & 0.20 & 0.40 & 0.25 & 0.43 & 0.31 & 0.46 & 0.45 & 0.50 & 0.19 & 0.39 & 0.16 & 0.37 \\
\hline Second stage of secondary level education (ISCED 3) & 0.56 & 0.50 & 0.53 & 0.50 & 0.56 & 0.50 & 0.60 & 0.49 & 0.36 & 0.48 & 0.26 & 0.44 & 0.35 & 0.48 & 0.37 & 0.48 & 0.35 & 0.48 & 0.41 & 0.49 & 0.42 & 0.49 & 0.51 & 0.50 \\
\hline $\begin{array}{l}\text { Less than second stage of secondary education } \\
\text { (ISCED 0-2) }\end{array}$ & 0.09 & 0.29 & 0.15 & 0.36 & 0.21 & 0.40 & 0.25 & 0.43 & 0.22 & 0.41 & 0.15 & 0.36 & 0.45 & 0.50 & 0.38 & 0.49 & 0.33 & 0.47 & 0.14 & 0.35 & 0.40 & 0.49 & 0.33 & 0.47 \\
\hline Labour market & & & & & & & & & & & & & & & & & & & & & & & & \\
\hline Working hours & 43.53 & 8.21 & 36.85 & 9.46 & 45.49 & 10.17 & 37.83 & 11.03 & 40.17 & 8.70 & 34.67 & 8.62 & 47.37 & 11.49 & 40.84 & 11.02 & 40.53 & 10.49 & 32.24 & 9.49 & 45.13 & 11.88 & 34.97 & 11.59 \\
\hline Part-time & 0.01 & 0.09 & 0.16 & 0.36 & 0.01 & 0.08 & 0.16 & 0.37 & 0.02 & 0.15 & 0.08 & 0.27 & 0.02 & 0.14 & 0.09 & 0.29 & 0.03 & 0.18 & 0.21 & 0.41 & 0.05 & 0.21 & 0.25 & 0.44 \\
\hline Full time & 0.99 & 0.09 & 0.84 & 0.36 & 0.99 & 0.08 & 0.84 & 0.37 & 0.98 & 0.15 & 0.92 & 0.27 & 0.98 & 0.14 & 0.91 & 0.29 & 0.97 & 0.18 & 0.79 & 0.41 & 0.95 & 0.21 & 0.75 & 0.44 \\
\hline Satisfaction in terms of (1-minimum; 6-maximum): & & & & & & & & & & & & & & & & & & & & & & & & \\
\hline $\begin{array}{l}\text { Working conditions/environment } \\
\end{array}$ & & & & & & & & & 4.06 & 1.22 & 4.37 & 1.19 & 3.66 & 1.32 & 4.11 & 1.20 & 2.34 & 5.30 & 3.60 & 4.03 & 1.79 & 5.79 & 3.42 & 4.44 \\
\hline Occupation & & & & & & & & & & & & & & & & & & & & & & & & \\
\hline Legislators, senior officials and managers & 0.03 & 0.17 & 0.01 & 0.09 & 0.07 & 0.26 & 0.05 & 0.22 & 0.06 & 0.24 & 0.02 & 0.13 & 0.17 & 0.38 & 0.14 & 0.35 & 0.08 & 0.26 & 0.02 & 0.13 & 0.14 & 0.35 & 0.07 & 0.25 \\
\hline Professionals & 0.31 & 0.46 & 0.21 & 0.41 & 0.10 & 0.30 & 0.06 & 0.23 & 0.26 & 0.44 & 0.41 & 0.49 & 0.10 & 0.30 & 0.12 & 0.33 & 0.23 & 0.42 & 0.46 & 0.50 & 0.09 & 0.29 & 0.09 & 0.28 \\
\hline Technicians and associate professionals & 0.20 & 0.40 & 0.43 & 0.50 & 0.14 & 0.34 & 0.24 & 0.43 & 0.07 & 0.26 & 0.12 & 0.33 & 0.04 & 0.20 & 0.06 & 0.23 & 0.17 & 0.37 & 0.11 & 0.32 & 0.10 & 0.30 & 0.11 & 0.31 \\
\hline Clerks & 0.08 & 0.27 & 0.15 & 0.35 & 0.06 & 0.24 & 0.21 & 0.41 & 0.23 & 0.42 & 0.31 & 0.46 & 0.05 & 0.23 & 0.17 & 0.38 & 0.12 & 0.32 & 0.23 & 0.42 & 0.04 & 0.20 & 0.24 & 0.42 \\
\hline Service workers and shop and market sales workers & 0.11 & 0.31 & 0.12 & 0.32 & 0.03 & 0.18 & 0.21 & 0.41 & 0.10 & 0.30 & 0.03 & 0.18 & 0.11 & 0.31 & 0.27 & 0.44 & 0.12 & 0.32 & 0.12 & 0.33 & 0.06 & 0.25 & 0.29 & 0.45 \\
\hline Craft and related & 0.11 & 0.31 & 0.01 & 0.09 & 0.39 & 0.49 & 0.09 & 0.28 & 0.09 & 0.29 & 0.01 & 0.07 & 0.31 & 0.46 & 0.13 & 0.34 & 0.10 & 0.30 & 0.00 & 0.05 & 0.27 & 0.44 & 0.02 & 0.15 \\
\hline Plant an & 0.09 & 0.29 & 0.01 & 0.12 & 0.15 & 0.36 & 0.06 & 0.23 & 0.09 & 0.29 & 0.01 & 0.07 & 0.15 & 0.36 & 0.03 & 0.17 & 0.08 & 0.26 & 0.01 & 0.09 & 0.20 & 0.40 & 0.12 & 0.33 \\
\hline Elementary occupations & 0.07 & 0.26 & 0.06 & 0.23 & 0.06 & 0.23 & 0.09 & 0.28 & 0.08 & 0.27 & 0.10 & 0.30 & 0.06 & 0.23 & 0.08 & 0.28 & 0.12 & 0.33 & 0.05 & 0.23 & 0.08 & 0.27 & 0.07 & 0.26 \\
\hline Hourly wages (ratio Public/Private) & Public/P & tivate & Public/1 & ivate & & & & & $\overline{\text { Public/1 }}$ & ivate & $\begin{array}{l}\text { Public/1 } \\
\text { un }\end{array}$ & ivate & & & & & Public/1 & tivate & Public/1 & & & & & \\
\hline Gross & 1.18 & & 1.34 & & & & & & 2.75 & & 3.03 & & & & & & 1.89 & & 2.01 & & & & & \\
\hline Net & 1.25 & & 1.37 & & & & & & 2.74 & & 3.01 & & & & & & 1.88 & & 1.88 & & & & & \\
\hline Observations & 675 & & 939 & & 2793 & & 1740 & & 551 & & 375 & & 1724 & & 921 & & 413 & & 366 & & 1216 & & 782 & \\
\hline
\end{tabular}




\section{Table 3 (cont.)}

\begin{tabular}{|c|c|c|c|c|c|c|c|c|c|c|c|c|c|c|c|c|c|c|c|c|c|c|c|c|}
\hline & \multicolumn{8}{|c|}{ ITALY } & \multicolumn{8}{|c|}{ NETHERLANDS } & \multicolumn{8}{|c|}{ PORTUGAL } \\
\hline & \multicolumn{4}{|c|}{$\begin{array}{l}\text { Public sector } \\
\end{array}$} & \multicolumn{4}{|c|}{$\begin{array}{l}\text { Private sector } \\
\end{array}$} & \multicolumn{4}{|c|}{ Public sector } & \multicolumn{4}{|c|}{ Private sector } & \multicolumn{4}{|c|}{ Public sector } & \multicolumn{4}{|c|}{ Private sector } \\
\hline & \multicolumn{2}{|c|}{ Men } & \multicolumn{2}{|c|}{ Women } & \multicolumn{2}{|c|}{ Men } & \multicolumn{2}{|c|}{ Women } & \multicolumn{2}{|c|}{ Men } & \multicolumn{2}{|c|}{ Women } & \multicolumn{2}{|c|}{ Men } & \multicolumn{2}{|c|}{ Women } & & & Wot & & M & & Won & nen \\
\hline & mean & sd & mean & & mean & sd & mean & & mean & sd & mean & sd & mean & sd & mean & & mean & sd & mean & sd & mean & sd & mean & sd \\
\hline Demographics & & & & & & & & & & & & & & & & & & & & & & & & \\
\hline Age & 42.07 & 9.41 & 40.69 & 8.81 & 38.16 & 10.14 & 36.15 & 9.91 & 42.89 & 8.73 & 38.52 & 9.03 & 39.17 & 9.46 & 36.58 & 9.60 & 40.08 & 10.16 & 38.69 & 9.53 & 36.67 & 11.04 & 35.96 & 10.71 \\
\hline Married & 0.80 & 0.40 & 0.73 & 0.44 & 0.68 & 0.47 & 0.61 & 0.49 & 0.76 & 0.43 & 0.55 & 0.50 & 0.69 & 0.46 & 0.57 & 0.49 & 0.76 & 0.43 & 0.69 & 0.46 & 0.68 & 0.47 & 0.67 & 0.47 \\
\hline No. of Children & 1.91 & 0.82 & 1.80 & 0.73 & 1.79 & 0.80 & 1.60 & 0.71 & 1.97 & 0.85 & 1.92 & 0.74 & 2.00 & 0.82 & 1.78 & 0.74 & 1.90 & 0.91 & 1.82 & 0.82 & 1.82 & 0.98 & 1.70 & 0.85 \\
\hline Sector of activity & & & & & & & & & & & & & & & & & & & & & & & & \\
\hline Industry $(\mathrm{E}+\mathrm{D}+\mathrm{F})$ & 0.09 & 0.28 & 0.03 & 0.17 & 0.52 & 0.50 & 0.31 & 0.46 & 0.07 & 0.25 & 0.02 & 0.14 & 0.40 & 0.49 & 0.16 & 0.37 & 0.09 & 0.29 & 0.02 & 0.14 & 0.54 & 0.50 & 0.31 & 0.46 \\
\hline Trade (G) & 0.01 & 0.10 & 0.02 & 0.12 & 0.19 & 0.39 & 0.25 & 0.43 & 0.00 & 0.04 & 0.00 & 0.00 & 0.18 & 0.38 & 0.21 & 0.40 & 0.01 & 0.12 & 0.01 & 0.07 & 0.22 & 0.41 & 0.22 & 0.41 \\
\hline Hotel and restaurants $(\mathrm{H})$ & 0.01 & 0.08 & 0.00 & 0.07 & 0.03 & 0.18 & 0.07 & 0.25 & 0.00 & 0.00 & 0.00 & 0.04 & 0.02 & 0.15 & 0.04 & 0.19 & 0.02 & 0.12 & 0.01 & 0.09 & 0.06 & 0.24 & 0.11 & 0.31 \\
\hline Transportation (I) & 0.12 & 0.33 & 0.04 & 0.19 & 0.06 & 0.25 & 0.02 & 0.15 & 0.02 & 0.15 & 0.01 & 0.11 & 0.10 & 0.30 & 0.05 & 0.22 & 0.10 & 0.30 & 0.03 & 0.18 & 0.05 & 0.21 & 0.02 & 0.16 \\
\hline $\begin{array}{l}\text { Financial intermediation, real estate and business } \\
(1+K)\end{array}$ & 0.03 & 0.18 & 0.02 & 0.13 & 0.11 & 0.31 & 0.14 & 0.34 & 0.04 & 0.20 & 0.03 & 0.16 & 0.20 & 0.40 & 0.23 & 0.42 & 0.02 & 0.14 & 0.02 & 0.15 & 0.08 & 0.28 & 0.07 & 0.25 \\
\hline $\begin{array}{l}\text { Education, health and social work and other } \\
\text { community services }(\mathrm{M}+\mathrm{N}+\mathrm{O}-\mathrm{Q})\end{array}$ & 0.34 & 0.47 & 0.68 & 0.47 & 0.08 & 0.27 & 0.21 & 0.41 & 0.43 & 0.50 & 0.71 & 0.45 & 0.09 & 0.28 & 0.31 & 0.46 & 0.22 & 0.41 & 0.67 & 0.47 & 0.04 & 0.19 & 0.26 & 0.44 \\
\hline Public administration and defense $(\mathrm{L})$ & 0.41 & 0.49 & 0.22 & 0.41 & 0.01 & 0.09 & 0.01 & 0.07 & 0.44 & 0.50 & 0.23 & 0.42 & 0.01 & 0.12 & 0.00 & 0.06 & 0.54 & 0.50 & 0.24 & 0.43 & 0.01 & 0.10 & 0.01 & 0.08 \\
\hline Education & & & & & & & & & & & & & & & & & & & & & & & & \\
\hline Recognised third level education (ISCED 5-7) & 0.19 & 0.39 & 0.24 & 0.43 & 0.08 & 0.26 & 0.06 & 0.24 & 0.43 & 0.50 & 0.38 & 0.48 & 0.19 & 0.39 & 0.18 & 0.39 & 0.13 & 0.33 & 0.25 & 0.43 & 0.04 & 0.20 & 0.04 & 0.20 \\
\hline Second stage of secondary level education (ISCED 3) & 0.45 & 0.50 & 0.59 & 0.49 & 0.39 & 0.49 & 0.47 & 0.50 & 0.43 & 0.50 & 0.46 & 0.50 & 0.59 & 0.49 & 0.53 & 0.50 & 0.19 & 0.39 & 0.26 & 0.44 & 0.11 & 0.31 & 0.15 & 0.35 \\
\hline $\begin{array}{l}\text { Less than second stage of secondary education } \\
\text { (ISCED 0-2) }\end{array}$ & 0.36 & 0.48 & 0.17 & 0.37 & 0.53 & 0.50 & 0.47 & 0.50 & 0.14 & 0.35 & 0.16 & 0.37 & 0.22 & 0.42 & 0.28 & 0.45 & 0.68 & 0.47 & 0.49 & 0.50 & 0.85 & 0.36 & 0.81 & 0.39 \\
\hline Labour market & & & & & & & & & & & & & & & & & & & & & & & & \\
\hline Working hours & 38.47 & 7.84 & 33.31 & 7.65 & 44.19 & 8.78 & 38.35 & 10.33 & 38.76 & 7.10 & 30.44 & 8.94 & 42.50 & 9.74 & 31.00 & 10.48 & 40.87 & 9.23 & 36.11 & 6.23 & 44.71 & 9.08 & 40.89 & 10.30 \\
\hline Part-time & 0.02 & 0.15 & 0.13 & 0.33 & 0.02 & 0.13 & 0.16 & 0.36 & 0.07 & 0.25 & 0.44 & 0.50 & 0.04 & 0.20 & 0.45 & 0.50 & 0.03 & 0.17 & 0.05 & 0.23 & 0.01 & 0.11 & 0.10 & 0.29 \\
\hline Full time & 0.98 & 0.15 & 0.87 & 0.33 & 0.98 & 0.13 & 0.84 & 0.36 & 0.93 & 0.25 & 0.56 & 0.50 & 0.96 & 0.20 & 0.55 & 0.50 & 0.97 & 0.17 & 0.95 & 0.23 & 0.99 & 0.11 & 0.90 & 0.29 \\
\hline Satisfaction in terms of (1-minimum; 6-maximum): & & & & & & & & & & & & & & & & & & & & & & & & \\
\hline Working conditions/environment & 4.10 & 1.56 & 4.26 & 1.41 & 3.88 & 1.38 & 4.24 & 1.29 & 4.21 & 1.22 & 4.31 & 1.17 & 4.35 & 1.33 & 4.41 & 1.26 & 4.22 & 1.20 & 4.22 & 0.90 & 4.12 & 1.21 & 4.15 & 1.05 \\
\hline Occupation & & & & & & & & & & & & & & & & & & & & & & & & \\
\hline Legislators, senior officials and managers & 0.03 & 0.18 & 0.00 & 0.05 & 0.04 & 0.19 & 0.02 & 0.13 & 0.10 & 0.30 & 0.05 & 0.22 & 0.17 & 0.37 & 0.08 & 0.27 & 0.02 & 0.13 & 0.00 & 0.04 & 0.09 & 0.29 & 0.08 & 0.26 \\
\hline Professionals & 0.15 & 0.36 & 0.38 & 0.49 & 0.05 & 0.22 & 0.05 & 0.22 & 0.43 & 0.49 & 0.33 & 0.47 & 0.14 & 0.35 & 0.11 & 0.32 & 0.14 & 0.35 & 0.20 & 0.40 & 0.04 & 0.19 & 0.03 & 0.18 \\
\hline Technicians and associate professionals & 0.13 & 0.34 & 0.19 & 0.39 & 0.12 & 0.33 & 0.08 & 0.26 & 0.20 & 0.40 & 0.30 & 0.46 & 0.19 & 0.40 & 0.23 & 0.42 & 0.12 & 0.33 & 0.32 & 0.47 & 0.06 & 0.24 & 0.07 & 0.25 \\
\hline Clerks & 0.27 & 0.45 & 0.30 & 0.46 & 0.10 & 0.30 & 0.26 & 0.44 & 0.06 & 0.25 & 0.18 & 0.39 & 0.08 & 0.27 & 0.26 & 0.44 & 0.12 & 0.32 & 0.19 & 0.39 & 0.07 & 0.26 & 0.13 & 0.33 \\
\hline Service workers and shop and market sales workers & 0.11 & 0.31 & 0.06 & 0.24 & 0.14 & 0.34 & 0.28 & 0.45 & 0.07 & 0.25 & 0.10 & 0.31 & 0.06 & 0.23 & 0.20 & 0.40 & 0.15 & 0.35 & 0.11 & 0.32 & 0.12 & 0.32 & 0.31 & 0.46 \\
\hline Craft and related trade workers + skilled workers & 0.10 & 0.30 & 0.01 & 0.08 & 0.35 & 0.48 & 0.13 & 0.34 & 0.06 & 0.25 & 0.00 & 0.06 & 0.21 & 0.40 & 0.02 & 0.15 & 0.17 & 0.38 & 0.01 & 0.09 & 0.40 & 0.49 & 0.16 & 0.37 \\
\hline Plant an & 0 . & 0.3 & 0. & & 0.1 & & 0.07 & & 0.0 & 0.16 & & 0. & 0.11 & 0.31 & & & 0.13 & 0.33 & 0.0 & 0. & 0.13 & 0.34 & 0.06 & 0.25 \\
\hline Elementary occupations & & 0.30 & 0.05 & 0.22 & 0.06 & 0.24 & 0.11 & 0.31 & 0.05 & 0.22 & 0.02 & 0.13 & 0.04 & 0.21 & 0.06 & 0.24 & 0.16 & 0.37 & 0.16 & 0.37 & 0.09 & 0.29 & 0.17 & 0.37 \\
\hline Hourly wages (ratio Public/Private) & Public/P & & Public/1 & & & & & & Public/r & & Public/1 & & & & & & Public/1 & & $\frac{\text { Public/P }}{\mathrm{P}}$ & & & & & \\
\hline Gross & 1.88 & & 1.95 & & & & & & 1.33 & & 1.23 & & & & & & 1.97 & & 2.74 & & & & & \\
\hline Net & 1.90 & & 1.96 & & & & & & 1.34 & & 1.21 & & & & & & 1.87 & & 2.53 & & & & & \\
\hline Observations & 947 & & 854 & & 2978 & & 1515 & & 560 & & 572 & & 2024 & & $\begin{array}{ll}1171 \\
\end{array}$ & & 492 & & 586 & & 2125 & & 1376 & \\
\hline
\end{tabular}




\section{Table 3 (cont.)}

\begin{tabular}{|c|c|c|c|c|c|c|c|c|c|c|c|c|c|c|c|c|c|c|c|c|c|c|c|c|}
\hline & \multicolumn{8}{|c|}{ SPAIN } & \multicolumn{8}{|c|}{$\begin{array}{l}\text { SWEDEN }^{1} \\
\end{array}$} & \multicolumn{8}{|c|}{ UNITED KINGDOM } \\
\hline & \multicolumn{4}{|c|}{ Public sector } & \multicolumn{4}{|c|}{$\begin{array}{l}\text { Private sector } \\
\end{array}$} & \multicolumn{4}{|c|}{$\begin{array}{l}\text { Public sector } \\
\end{array}$} & \multicolumn{4}{|c|}{$\begin{array}{l}\text { Private sector } \\
\end{array}$} & \multicolumn{4}{|c|}{$\begin{array}{l}\text { Public sector } \\
\end{array}$} & \multicolumn{4}{|c|}{ Private sector } \\
\hline & \multicolumn{2}{|c|}{ Men } & \multicolumn{2}{|c|}{ Women } & \multicolumn{2}{|c|}{ Men } & \multicolumn{2}{|c|}{ Women } & \multicolumn{2}{|c|}{ Men } & \multicolumn{2}{|c|}{ Women } & \multicolumn{2}{|c|}{ Men } & \multicolumn{2}{|c|}{ Women } & & & Won & & Me & & Wor & \\
\hline & mean & sd & mean & sd & mean & sd & mean & sd & mean & sd & mean & sd & mean & sd & mean & sd & mean & sd & mean & sd & mean & $\mathrm{sd}$ & mean & sd \\
\hline Demographics & & & & & & & & & & & & & & & & & & & & & & & & \\
\hline Age & 40.66 & 9.64 & 39.10 & 8.81 & 37.52 & 10.37 & 34.99 & 9.92 & 42.31 & 10.21 & 41.58 & 10.28 & 38.37 & 10.68 & 38.70 & 11.03 & 39.35 & 9.66 & 39.80 & 9.83 & 37.61 & 10.69 & 37.03 & 10.84 \\
\hline Married & 0.77 & 0.42 & 0.66 & 0.48 & 0.68 & 0.47 & 0.56 & 0.50 & 0.50 & 0.50 & 0.56 & 0.50 & 0.45 & 0.50 & 0.49 & 0.50 & 0.60 & 0.49 & 0.65 & 0.48 & 0.59 & 0.49 & 0.55 & 0.50 \\
\hline No. of Children & 2.07 & 0.92 & 1.92 & 0.88 & 1.97 & 0.87 & 1.83 & 0.83 & 1.81 & 0.92 & 1.94 & 0.88 & 1.84 & 0.80 & 1.82 & 0.83 & 1.82 & 0.75 & 1.81 & 0.76 & 1.87 & 0.85 & 1.73 & 0.76 \\
\hline Sector of activity & & & & & & & & & & & & & & & & & & & & & & & & \\
\hline Industry $(\mathrm{E}+\mathrm{D}+\mathrm{F})$ & 0.11 & 0.32 & 0.02 & 0.13 & 0.51 & 0.50 & 0.19 & 0.39 & 0.05 & 0.22 & 0.01 & 0.07 & 0.49 & 0.50 & 0.26 & 0.44 & 0.04 & 0.19 & 0.00 & 0.05 & 0.48 & 0.50 & 0.23 & 0.42 \\
\hline Trade (G) & 0.01 & 0.07 & 0.00 & 0.07 & 0.18 & 0.39 & 0.26 & 0.44 & 0.01 & 0.10 & 0.00 & 0.04 & 0.16 & 0.37 & 0.23 & 0.42 & 0.00 & 0.00 & 0.00 & 0.04 & 0.16 & 0.36 & 0.22 & 0.41 \\
\hline Hotel and restaurants $(\mathrm{H})$ & 0.00 & 0.06 & 0.00 & 0.05 & 0.07 & 0.26 & 0.10 & 0.30 & 0.00 & 0.06 & 0.00 & 0.04 & 0.02 & 0.15 & 0.07 & 0.25 & 0.00 & 0.00 & 0.01 & 0.11 & 0.04 & 0.19 & 0.07 & 0.26 \\
\hline Transportation (I) & 0.10 & 0.30 & 0.03 & 0.16 & 0.07 & 0.26 & 0.03 & 0.17 & 0.03 & 0.17 & 0.01 & 0.09 & 0.12 & 0.32 & 0.10 & 0.29 & 0.09 & 0.29 & 0.01 & 0.09 & 0.08 & 0.28 & 0.04 & 0.21 \\
\hline $\begin{array}{l}\text { Financial intermediation, real estate and business } \\
(0+K)\end{array}$ & 0.02 & 0.14 & 0.02 & 0.12 & 0.10 & 0.30 & 0.13 & 0.34 & 0.07 & 0.26 & 0.02 & 0.15 & 0.14 & 0.35 & 0.17 & 0.38 & 0.04 & 0.19 & 0.01 & 0.11 & 0.18 & 0.38 & 0.22 & 0.41 \\
\hline $\begin{array}{l}\text { Education, health and social work and other } \\
\text { community services (M+N+O-Q) }\end{array}$ & 0.33 & 0.47 & 0.64 & 0.48 & 0.06 & 0.24 & 0.28 & 0.45 & 0.52 & 0.50 & 0.83 & 0.37 & 0.06 & 0.24 & 0.17 & 0.38 & 0.34 & 0.48 & 0.74 & 0.44 & 0.06 & 0.25 & 0.21 & 0.41 \\
\hline Public administration and defense (L) & 0.43 & 0.49 & 0.29 & 0.45 & 0.00 & 0.04 & 0.00 & 0.05 & 0.32 & 0.47 & 0.13 & 0.33 & 0.00 & 0.07 & 0.01 & 0.08 & 0.49 & 0.50 & 0.23 & 0.42 & 0.00 & 0.04 & 0.00 & 0.05 \\
\hline Education & & & & & & & & & & & & & & & & & & & & & & & & \\
\hline Recognised third level education (ISCED 5-7) & 0.46 & 0.50 & 0.62 & 0.49 & 0.19 & 0.39 & 0.24 & 0.43 & 0.56 & 0.50 & 0.44 & 0.50 & 0.22 & 0.41 & 0.23 & 0.42 & 0.61 & 0.49 & 0.50 & 0.50 & 0.41 & 0.49 & 0.32 & 0.47 \\
\hline Second stage of secondary level education (ISCED 3) & 0.22 & 0.42 & 0.17 & 0.38 & 0.21 & 0.41 & 0.27 & 0.44 & 0.38 & 0.48 & 0.47 & 0.50 & 0.56 & 0.50 & 0.59 & 0.49 & 0.12 & 0.33 & 0.16 & 0.36 & 0.16 & 0.36 & 0.14 & 0.34 \\
\hline $\begin{array}{l}\text { Less than second stage of secondary education } \\
\text { (ISCED 0-2) }\end{array}$ & 0.31 & 0.46 & 0.20 & 0.40 & 0.60 & 0.49 & 0.49 & 0.50 & 0.06 & 0.24 & 0.09 & 0.29 & 0.22 & 0.41 & 0.19 & 0.39 & 0.26 & 0.44 & 0.34 & 0.47 & 0.43 & 0.50 & 0.54 & 0.50 \\
\hline Labour market & & & & & & & & & & & & & & & & & & & & & & & & \\
\hline Working hours & 40.18 & 7.88 & 36.65 & 6.42 & 46.00 & 11.47 & 39.82 & 12.28 & 41.02 & 8.50 & 35.44 & 7.74 & 41.17 & 6.77 & 36.02 & 7.56 & 44.11 & 10.39 & 36.22 & 11.03 & 47.96 & 11.80 & 36.07 & 11.90 \\
\hline Part-time & 0.01 & 0.12 & 0.04 & 0.20 & 0.03 & 0.16 & 0.17 & 0.37 & 0.05 & 0.23 & 0.17 & 0.38 & 0.02 & 0.15 & 0.16 & 0.37 & 0.00 & 0.00 & 0.00 & 0.00 & 0.00 & 0.00 & 0.00 & 0.00 \\
\hline Full time & 0.99 & 0.12 & 0.96 & 0.20 & 0.97 & 0.16 & 0.83 & 0.37 & 0.95 & 0.23 & 0.83 & 0.38 & 0.98 & 0.15 & 0.84 & 0.37 & 1.00 & 0.00 & 1.00 & 0.00 & 1.00 & 0.00 & 1.00 & 0.00 \\
\hline Satisfaction in terms of (1-minimum; 6-maximum): & & & & & & & & & & & & & & & & & & & & & & & & \\
\hline Working conditions/environment & 4.18 & 1.59 & 4.30 & 1.58 & 4.11 & 1.37 & 4.25 & 1.59 & & & & & & & & & & & & & & & & \\
\hline Occupation & & & & & & & & & & & & & & & & & & & & & & & & \\
\hline Legislators, senior officials and managers & 0.02 & 0.16 & 0.01 & 0.09 & 0.11 & 0.31 & 0.10 & 0.30 & & & & & & & & & 0.15 & 0.36 & 0.08 & 0.27 & 0.22 & 0.41 & 0.15 & 0.36 \\
\hline Professionals & 0.30 & 0.46 & 0.44 & 0.50 & 0.07 & 0.25 & 0.09 & 0.29 & & & & & & & & & 0.23 & 0.42 & 0.24 & 0.43 & 0.12 & 0.33 & 0.09 & 0.28 \\
\hline Technicians and associate professionals & 0.14 & 0.35 & 0.14 & 0.35 & 0.10 & 0.31 & 0.10 & 0.30 & & & & & & & & & 0.18 & 0.38 & 0.22 & 0.41 & 0.10 & 0.31 & 0.11 & 0.32 \\
\hline Clerks & 0.12 & 0.32 & 0.17 & 0.38 & 0.05 & 0.22 & 0.14 & 0.35 & & & & & & & & & 0.15 & 0.36 & 0.21 & 0.41 & 0.07 & 0.25 & 0.29 & 0.46 \\
\hline Service workers and shop and market sales workers & 0.15 & 0.36 & 0.11 & 0.31 & 0.11 & 0.31 & 0.27 & 0.44 & & & & & & & & & 0.15 & 0.36 & 0.19 & 0.40 & 0.05 & 0.22 & 0.22 & 0.41 \\
\hline Craft and related trade workers + skilled workers & 0.13 & 0.33 & 0.01 & 0.10 & 0.31 & 0.46 & 0.07 & 0.25 & & & & & & & & & 0.07 & 0.25 & 0.00 & 0.05 & 0.24 & 0.42 & 0.02 & 0.14 \\
\hline Plant and machine operators and assemblers & 0.06 & 0.24 & 0.00 & 0.05 & 0.14 & 0.35 & 0.04 & 0.19 & & & & & & & & & 0.03 & 0.16 & 0.00 & 0.05 & 0.15 & 0.35 & 0.06 & 0.23 \\
\hline Elementary occupations & 0.08 & 0.28 & 0.11 & 0.31 & 0.12 & 0.32 & 0.19 & 0.39 & & & & & & & & & 0.06 & 0.23 & 0.05 & 0.23 & 0.06 & 0.24 & 0.06 & 0.24 \\
\hline Hourly wages (ratio Public/Private) & Public/1 & & Public/P & & & & & & & & & & & & & & Public/1 & & Public/P & & & & & \\
\hline Gross & 1.84 & & 2.19 & & & & & & & & & & & & & & 1.41 & & 1.37 & & & & & \\
\hline Net & 1.82 & & 2.12 & & & & & & & & & & & & & & 1.38 & & 1.32 & & & & & \\
\hline Observations & 526 & & 450 & & 2635 & & 1242 & & 291 & & 785 & & 1053 & & 619 & & 376 & & 690 & & 2117 & & 1486 & \\
\hline
\end{tabular}

Notes: 1. For Sweden, there is no data on occupation and on wages These questions were not asked or information was not available for other reasons 


\subsection{Gender Differences in the Probability of Working in the Public (vs. Private) Sector -}

\section{A Heckit Model}

Table 4 presents estimates of the effects of a wide array of individual and job characteristics on the probability of working in PS vs. working in the private sector among workers in the age bracket 20-59. Estimations are carried out separately for each country. In all cases, but Denmark, Greece and The Netherlands (see below), we control for sample selection bias by applying the conventional Heckman's correction procedure, given that selection bias may arise from the fact that observations on the choice of PS/private sector jobs are obviously restricted for those individuals who are already working in those sectors. Hence, especially in countries with lower LFP, these individuals may not be sufficiently representative of the overall working-age population leading to biased estimates if we were to draw implications for the latter. As is well known, the Heckman method is a two-stage procedure. In the first stage, a selection-into-the sample equation (i.e., the probability of working for all individuals between 20 and 59 years) is estimated through a Probit model. In the second stage, the probability of working in PS vs. private sector (outcome equation) is estimated conditional on the probability of working (the so-called inverse Mills ratio).

For the model to be well identified, a usual requirement is that the selection equation should include at least one variable not appearing in the outcome equation. In this respect, we use the regional LFP rates and the regional average age in the first stage equation, assuming that they affect only the probability of working but not the relative probability of working in PS vs. private sector. Results reveal that indeed these two variables seem to affect the probability of working vs. not working in most cases.

Unfortunately, we cannot include these identifiers in the case of Denmark, Greece and The Netherlands either because regional information is not available or because there are too many missing observations. Therefore, for these three countries, we are only able to run a Probit model for the probability of working in PS vs. private sector without controlling for potential sample selection bias.

The explanatory variables in the selection equation are the two above-mentioned identifiers at the regional level (regional LFP rate and regional average wage) plus demographics (including education). As for the outcome equation, besides the demographics, we also include the number of weekly working hours, degree of satisfaction with the working conditions, occupation, industry 
(sector of activity), hourly wages, and the degree of femaleness (proportion of females in PS employment) to capture the segregation phenomenon described in Hypothesis (d).

For each country, we present estimates for three different samples, which include: (ALL) all workers, (W) women, and (M) men. In order to facilitate the interpretation, we report the coefficients in the form of marginal effects. For continuous explanatory variables, the marginal effect is calculated at the sample mean of each of the variables and, for dummy explanatory variables, as the discrete change in the dependent variable when the dummy variable shifts from 0 to 1 .

We next describe the main results separately by country to then summarize the main conclusions at the end of this section.

1. Belgium: From the estimation with the (ALL) sample, it is interesting to observe that Belgian females, other things equal, have a lower probability to work in the PS (relative to the private sector) than males. Regarding the (W) and (M) samples, we find that being an older women and having children increase that probability, whilst no similar effects are found for men. Educational attainment barely affects the probability of choosing PS jobs for either men or women.

Professional is the occupational category that has a larger positive effect on the relative probability of working in the PS. As for industries, not only in Belgium but also in all countries, the probability of working in PS is, as expected, highest in Public Administration and Defense. Finally, a higher degree of satisfaction with working conditions (in either private or public sectors) leads to a lower relative probability of working in PS. One way to interpret this last result would be that, since in general better working conditions are taken as granted in PS, an increase in the overall degree of job satisfaction may affect participation in the private sector relatively more strongly.

2. Denmark ${ }^{3}$ : From the estimation with the (ALL) sample, we find that (hereafter, other things equal), Danish women are more likely to work in the PS than men. As with the (W) and (M) samples, it is found that older women are more likely to work in the PS, but neither marital status nor number of children seem to affect this probability. As we will see

\footnotetext{
${ }^{3}$ Recall that for Denmark we do not control for sample selection bias, as there is no disaggregation by regions in the ECHP. Thus, as mentioned earlier, we present the results from the estimation of a Probit model for the probability of working in the PS vs. the private sector.
} 
below for other countries, having higher education (university) increases the probability of working in PS for both men and women.

3. France: From the (ALL) sample, we find that the probability of working in the PS is not affected by gender. Both men and women working in PS tend to be older than those working in the private sector. As regards educational attainment, contrary to what we observe for Denmark or Sweden, it does not have statistically significant effects on the choice of the sector for both men and women.

4. Germany: From the (ALL) sample, German women are more likely to work in the PS than men. Children status is not a relevant determinant to work in one or the other sector, whereas being married only increases the female probability of working in the PS. Regarding educational attainment, there are significant differences by gender: while males in the PS tend to have achieved university education, women in the PS tend to be less educated in the private sector.

5. Greece ${ }^{4}$ : From the (ALL) sample, we find that the probability of working in the PS does not depend on gender. As for the (W) sample, women in the PS are older and have children. Educational attainment does not seem to affect the probability of choosing one or the other sector. Regarding the (M) sample, as in Denmark or The Netherlands, higher education increases the probability that Greek men work in the PS.

6. Ireland: From the (ALL) sample, we find that women tend to have a higher probability of working in the PS relative to the private one. As in most countries, workers in the PS tend to be older. However, neither marital nor children status seem to affect the probability of working in the PS. With respect to the level of education, taking workers altogether, we find that low educated individuals are more likely to work in the PS.

7. Italy: From the (ALL) sample we find that females are less likely to work in the PS. As in other countries, both female and male workers in the PS tend to be older than in the private one. Family variables, such as being married and having children increase the probability of working in the PS. Moreover, as in Denmark, Spain, Sweden or UK, a higher level of education increases the probability of working in the PS vs. the private sector for both women and men.

\footnotetext{
${ }^{4}$ The comment for Denmark applies also here.
} 
8. Portugal. From the (ALL) sample, we find that women are more likely to work in the PS. As in most countries, Portuguese workers in the PS tend to be older. As for family variables, results point out that men and women who are single without children are the ones more likely to work in the PS, in contrast to what happens in most other countries. Regarding education, it is not clear that it makes a dent with respect to the probability of working in the PS.

9. Spain: From the (ALL) sample, we find that women are less likely to work in the PS (as we found for Belgium, Italy and the Netherlands). Workers in the PS tend to be older than those in the private sector. Being married or having children do not matter. However, the level of education seems to be a relevant factor: having university studies increases the probability of working in the PS to a great extent, particularly for women. As in Belgium and the Netherlands, the overall degree of job satisfaction decreases the probability of working in the PS.

10. Sweden ${ }^{5}$ : From the (ALL) sample, we find that females are more likely to work in the PS. In addition, from the (W) sample, we can see that older and married women with kids are more likely to be in the PS. Furthermore, the effect of the level of education on the probability of working in the PS is positive and highly significant for both men and women, and the impact is particularly strong for women with university education.

11. The Netherlands: ${ }^{6}$ From the (ALL) sample, we find that females are less likely to work in the PS than males. An explanation for this result could be that the availability of part-time jobs is almost identical in the PS and the private sector (about 45\%, see Table 1) and therefore this feature does not become a source of attraction for women to the PS. Family variables, such as being married and having children, do not affect the probability of working in the PS, either for men or for women. Men (not women) working in the PS tend to be more educated. Finally, overall satisfaction with working conditions decreases the probability of working in the PS.

12. UK: From the (ALL) sample, we find no gender differences with respect to the probability of working in the PS. This sector attracts older workers but family status -being married or having children - does not seem to have any effect. However, in the case of British

\footnotetext{
${ }^{5}$ ECHP does not provide data on occupation and wages at the individual level for Sweden.

${ }^{6}$ The comment for Denmark and Greece applies also here.
} 
women, being married and not having children seem to increase the probability of working in the PS and, like in other countries, workers in the PS are highly educated. 
Table 4. Estimation of the probability of working in the PS (ECHP, all waves) - Heckman Probit procedure

\begin{tabular}{|c|c|c|c|c|c|c|c|c|c|c|c|c|}
\hline \multirow{2}{*}{ Outcome equation - Probability to work in the public sector } & \multicolumn{3}{|c|}{ BELGIUM } & \multicolumn{3}{|c|}{ DENMARK (probit model) } & \multicolumn{3}{|c|}{ FRANCE } & \multicolumn{3}{|c|}{ GERMANY } \\
\hline & All & Men & Women & All & Men & Women & All & Men & Women & All & Men & Women \\
\hline \multicolumn{13}{|l|}{ Demographics } \\
\hline Female & $\begin{array}{c}-0.077^{* * *} * \\
(0.010)\end{array}$ & & & $\begin{array}{c}0.125 * * * \\
(0.018)\end{array}$ & & & $\begin{array}{c}0.005 \\
(0.010)\end{array}$ & & & $\begin{array}{c}0.095 * * * \\
(0.015)\end{array}$ & & \\
\hline Age & $\begin{array}{c}0.001 \\
(0.001)\end{array}$ & $\begin{array}{l}-0.001 \\
(0.001)\end{array}$ & $\begin{array}{c}0.003 * * \\
(0.001)\end{array}$ & $\begin{array}{c}0.006 * * * \\
(0.001)\end{array}$ & $\begin{array}{c}0.007 * * * \\
(0.001)\end{array}$ & $\begin{array}{c}0.003 * * \\
(0.001)\end{array}$ & $\begin{array}{c}0.005 * * * \\
(0.000)\end{array}$ & $\begin{array}{c}0.004 * * \\
(0.001)\end{array}$ & $\begin{array}{c}0.006^{* * *} \\
(0.001)\end{array}$ & $\begin{array}{c}0.002^{* * *} \\
(0.001)\end{array}$ & $\begin{array}{l}0.000 \\
(0.000)\end{array}$ & $\begin{array}{c}0.002^{* *} \\
(0.001)\end{array}$ \\
\hline Married & $\begin{array}{c}-0.014 \\
(0.014)\end{array}$ & $\begin{array}{l}0.020 \\
(0.016)\end{array}$ & $\begin{array}{c}-0.058^{* *} \\
(0.028)\end{array}$ & $\begin{array}{c}-0.070^{* *} \\
(0.028)\end{array}$ & $\begin{array}{c}-0.104 * * * * \\
(0.026)\end{array}$ & $\begin{array}{c}0.011 \\
(0.043)\end{array}$ & $\begin{array}{l}-0.015 \\
(0.013)\end{array}$ & $\begin{array}{c}0.030 \\
(0.026)\end{array}$ & $\begin{array}{l}-0.032 \\
(0.020)\end{array}$ & $\begin{array}{l}-0.011 \\
(0.014)\end{array}$ & $\begin{array}{l}0.014 \\
(0.012)\end{array}$ & $\begin{array}{l}0.054^{* *} \\
(0.021)\end{array}$ \\
\hline Children & $\begin{array}{c}0.031 * * \\
(0.013)\end{array}$ & $\begin{array}{l}0.026 \\
(0.020)\end{array}$ & $\begin{array}{l}0.040^{*} \\
(0.023)\end{array}$ & $\begin{array}{l}-0.006 \\
(0.027)\end{array}$ & $\begin{array}{c}0.001 \\
(0.024)\end{array}$ & $\begin{array}{c}0.008 \\
(0.039)\end{array}$ & $\begin{array}{c}0.013 \\
(0.013)\end{array}$ & $\begin{array}{c}0.028 \\
(0.040)\end{array}$ & $\begin{array}{l}0.014 \\
(0.018)\end{array}$ & $\begin{array}{c}-0.025 \\
(0.017)\end{array}$ & $\begin{array}{c}-0.008 \\
(0.017)\end{array}$ & $\begin{array}{c}0.036 \\
(0.027)\end{array}$ \\
\hline Married*Children & $\begin{array}{r}-0.025 \\
(0.017) \\
\end{array}$ & $\begin{array}{r}-0.019 \\
(0.024) \\
\end{array}$ & $\begin{array}{l}-0.012 \\
(0.032) \\
\end{array}$ & $\begin{array}{l}0.004 \\
(0.034) \\
\end{array}$ & $\begin{array}{r}-0.013 \\
(0.030) \\
\end{array}$ & $\begin{array}{c}0.006 \\
(0.052) \\
\end{array}$ & $\begin{array}{r}-0.023 \\
(0.016) \\
\end{array}$ & $\begin{array}{r}-0.013 \\
(0.027) \\
\end{array}$ & $\begin{array}{c}-0.053^{* *} \\
(0.025)\end{array}$ & $\begin{array}{r}-0.000 \\
(0.021) \\
\end{array}$ & $\begin{array}{r}-0.008 \\
(0.019) \\
\end{array}$ & $\begin{array}{r}-0.014 \\
(0.032) \\
\end{array}$ \\
\hline \multicolumn{13}{|l|}{ Education } \\
\hline Recognised third level education (ISCED 5-7) & $\begin{array}{c}0.040 * * \\
(0.017)\end{array}$ & $\begin{array}{l}-0.007 \\
(0.016)\end{array}$ & $\begin{array}{c}0.069 \\
(0.043)\end{array}$ & $\begin{array}{c}0.091 * * * \\
(0.027)\end{array}$ & $\begin{array}{c}0.087 * * * \\
(0.027)\end{array}$ & $\begin{array}{l}0.072^{*} \\
(0.040)\end{array}$ & $\begin{array}{c}0.017 \\
(0.012)\end{array}$ & $\begin{array}{c}0.009 \\
(0.016)\end{array}$ & $\begin{array}{c}0.026 \\
(0.018)\end{array}$ & $\begin{array}{c}-0.049 * \\
(0.027)\end{array}$ & $\begin{array}{c}0.097 * * * \\
(0.022)\end{array}$ & $\begin{array}{c}-0.109 * * * \\
(0.028)\end{array}$ \\
\hline $\begin{array}{l}\text { Second stage of secondary level education } \\
\text { (ISCED 3) }\end{array}$ & $\begin{array}{l}0.021 * \\
(0.012) \\
\end{array}$ & $\begin{array}{l}0.022^{*} \\
(0.013)\end{array}$ & $\begin{array}{r}0.008 \\
(0.029)\end{array}$ & $\begin{array}{l}0.001 \\
(0.023)\end{array}$ & $\begin{array}{l}0.040^{*} \\
(0.020)\end{array}$ & $\begin{array}{l}-0.031 \\
(0.034) \\
\end{array}$ & $\begin{array}{r}0.004 \\
(0.009) \\
\end{array}$ & $\begin{array}{l}0.022^{* *} \\
(0.010)\end{array}$ & $\begin{array}{l}-0.011 \\
(0.015) \\
\end{array}$ & $\begin{array}{l}-0.018 \\
(0.017) \\
\end{array}$ & $\begin{array}{c}0.079 * * * \\
(0.012)\end{array}$ & $\begin{array}{c}-0.102 * * * \\
(0.019) \\
\end{array}$ \\
\hline \multicolumn{13}{|l|}{ Labour market } \\
\hline Working hours & $\begin{array}{c}-0.001 \\
(.) \\
\end{array}$ & $\begin{array}{c}-0.002 * * * \\
(0.001) \\
\end{array}$ & $\begin{array}{c}0.000 \\
(0.001) \\
\end{array}$ & $\begin{array}{c}-0.002 * * \\
(0.001) \\
\end{array}$ & $\begin{array}{c}-0.003^{* * *} \\
(0.001) \\
\end{array}$ & $\begin{array}{l}0.003 * * \\
(0.001)\end{array}$ & $\begin{array}{c}-0.004 * * * \\
(0.000) \\
\end{array}$ & $\begin{array}{c}-0.008 * * * \\
(0.001) \\
\end{array}$ & $\begin{array}{l}0.001 * \\
(0.001) \\
\end{array}$ & $\begin{array}{c}-0.001 * * * \\
(0.000) \\
\end{array}$ & $\begin{array}{c}-0.003 * * * \\
(0.000)\end{array}$ & $\begin{array}{c}0.003 * * * \\
(0.001)\end{array}$ \\
\hline \multicolumn{13}{|l|}{ Satisfaction in terms of (1-minimum; 6-maximum): } \\
\hline Working conditions/environment & $\begin{array}{c}-0.004 * * \\
(0.002)\end{array}$ & $\begin{array}{l}-0.004 * \\
(0.002)\end{array}$ & $\begin{array}{r}-0.006 \\
(0.004) \\
\end{array}$ & $\begin{array}{c}-0.019 * * * \\
(0.006) \\
\end{array}$ & $\begin{array}{l}-0.002 \\
(0.005) \\
\end{array}$ & $\begin{array}{c}-0.034 * * * \\
(0.011) \\
\end{array}$ & $\begin{array}{l}-0.000 \\
(0.002) \\
\end{array}$ & $\begin{array}{l}0.005^{* *} \\
(0.002)\end{array}$ & $\begin{array}{l}-0.005 \\
(0.004) \\
\end{array}$ & & & \\
\hline \multicolumn{13}{|l|}{ Occupation } \\
\hline Professionals & $\begin{array}{c}0.139 * * * \\
(0.021)\end{array}$ & $\begin{array}{c}0.130 * * * \\
(0.023)\end{array}$ & $\begin{array}{c}0.155^{* * *} \\
(0.050)\end{array}$ & $\begin{array}{c}0.231 * * * \\
(0.037)\end{array}$ & $\begin{array}{c}0.106 * * * \\
(0.032)\end{array}$ & $\begin{array}{c}0.325 * * * \\
(0.046)\end{array}$ & $\begin{array}{c}0.328^{* * *} \\
(0.022)\end{array}$ & $\begin{array}{c}0.222^{* * *} \\
(0.037)\end{array}$ & $\begin{array}{c}0.445^{* * *} \\
(0.045)\end{array}$ & $\begin{array}{c}0.173^{* * *} \\
(0.025)\end{array}$ & $\begin{array}{c}0.057 * * * \\
(0.018)\end{array}$ & $\begin{array}{c}0.418^{* * *} \\
(0.055)\end{array}$ \\
\hline Technicians and associate professionals & $\begin{array}{c}0.085^{* * *} * \\
(0.021)\end{array}$ & $\begin{array}{c}0.088^{* * *} \\
(0.022)\end{array}$ & $\begin{array}{c}0.074 \\
(0.047)\end{array}$ & $\begin{array}{c}0.216^{* * * *} \\
(0.038)\end{array}$ & $\begin{array}{c}0.100^{* * *} \\
(0.035)\end{array}$ & $\begin{array}{c}0.335 * * * \\
(0.052)\end{array}$ & $\begin{array}{c}0.266^{* * * *} \\
(0.021)\end{array}$ & $\begin{array}{c}0.160^{* * *} * \\
(0.031)\end{array}$ & $\begin{array}{c}0.321 * * * \\
(0.042)\end{array}$ & $\begin{array}{c}0.130^{* * * *} \\
(0.024)\end{array}$ & $\begin{array}{c}0.012 \\
(0.018)\end{array}$ & $\begin{array}{c}0.364 * * * \\
(0.055)\end{array}$ \\
\hline Clerks & $\begin{array}{c}0.071 * * * \\
(0.020)\end{array}$ & $\begin{array}{c}0.058 * * * \\
(0.022)\end{array}$ & $\begin{array}{l}0.085^{*} \\
(0.047)\end{array}$ & $\begin{array}{c}0.169^{* * *} * \\
(0.043)\end{array}$ & $\begin{array}{c}0.265 * * * \\
(0.052)\end{array}$ & $\begin{array}{c}0.225 * * * \\
(0.059)\end{array}$ & $\begin{array}{c}0.228^{* * *} \\
(0.022)\end{array}$ & $\begin{array}{c}0.211 \text { *** } \\
(0.039)\end{array}$ & $\begin{array}{c}0.229^{* * *} \\
(0.043)\end{array}$ & $\begin{array}{c}0.216^{* * *} \\
(0.025)\end{array}$ & $\begin{array}{c}0.117 * * * \\
(0.021)\end{array}$ & $\begin{array}{c}0.412^{* * *} \\
(0.055)\end{array}$ \\
\hline $\begin{array}{l}\text { Service workers and shop and market sales } \\
\text { workers }\end{array}$ & $\begin{array}{c}0.020 \\
(0.024)\end{array}$ & $\begin{array}{c}0.044 \\
(0.029)\end{array}$ & $\begin{array}{l}-0.007 \\
(0.052)\end{array}$ & $\begin{array}{c}0.334 * * * \\
(0.040)\end{array}$ & $\begin{array}{l}0.103^{* *} \\
(0.046)\end{array}$ & $\begin{array}{c}0.436 * * * \\
(0.040)\end{array}$ & $\begin{array}{c}0.223 * * * \\
(0.023)\end{array}$ & $\begin{array}{c}0.187^{* * *} \\
(0.036)\end{array}$ & $\begin{array}{c}0.234^{* * *} \\
(0.044)\end{array}$ & $\begin{array}{c}0.045^{*} \\
(0.027)\end{array}$ & $\begin{array}{c}0.054^{* *} \\
(0.024)\end{array}$ & $\begin{array}{c}0.209 * * * \\
(0.056)\end{array}$ \\
\hline $\begin{array}{l}\text { Craft and related trade workers }+ \text { skilled } \\
\text { workers }\end{array}$ & $\begin{array}{c}0.075 * * * \\
(0.025)\end{array}$ & $\begin{array}{l}0.034 \\
(0.025)\end{array}$ & $\begin{array}{l}0.127 * \\
(0.070)\end{array}$ & $\begin{array}{c}0.123^{* *} \\
(0.058)\end{array}$ & $\begin{array}{l}-0.021 \\
(0.036)\end{array}$ & $\begin{array}{c}0.369 * * * \\
(0.039)\end{array}$ & $\begin{array}{c}0.208^{* * *} * \\
(0.023)\end{array}$ & $\begin{array}{c}0.127 * * * \\
(0.029)\end{array}$ & $\begin{array}{c}0.262 * * * \\
(0.064)\end{array}$ & $\begin{array}{c}0.154^{* * *} \\
(0.027)\end{array}$ & $\begin{array}{c}0.047 * * \\
(0.020)\end{array}$ & $\begin{array}{c}0.320 * * * \\
(0.065)\end{array}$ \\
\hline Plant and machine operators and assemblers & $\begin{array}{l}-0.005 \\
(0.027)\end{array}$ & $\begin{array}{c}-0.034 \\
(0.027)\end{array}$ & $\begin{array}{c}0.105 \\
(0.081)\end{array}$ & $\begin{array}{c}0.161 * * * \\
(0.049)\end{array}$ & $\begin{array}{c}0.090 * * \\
(0.041)\end{array}$ & $\begin{array}{c}0.257 * * * \\
(0.078)\end{array}$ & $\begin{array}{c}0.072^{* * *} \\
(0.025)\end{array}$ & $\begin{array}{l}0.044^{*} \\
(0.024)\end{array}$ & $\begin{array}{l}-0.043 \\
(0.057)\end{array}$ & $\begin{array}{c}0.100^{* * *} \\
(0.028)\end{array}$ & $\begin{array}{c}0.034^{*} \\
(0.019)\end{array}$ & $\begin{array}{c}0.235 * * * \\
(0.076)\end{array}$ \\
\hline Elementary occupations & $\begin{array}{l}0.038^{*} \\
(0.022) \\
\end{array}$ & $\begin{array}{c}0.010 \\
(0.024) \\
\end{array}$ & $\begin{array}{c}0.072 \\
(0.053) \\
\end{array}$ & $\begin{array}{c}0.263^{* * *} * \\
(0.049) \\
\end{array}$ & $\begin{array}{c}0.139 * * * \\
(0.052) \\
\end{array}$ & $\begin{array}{c}0.338 * * * \\
(0.042) \\
\end{array}$ & $\begin{array}{c}0.221 * * * \\
(0.024) \\
\end{array}$ & $\begin{array}{c}0.179 * * * \\
(0.036) \\
\end{array}$ & $\begin{array}{c}0.236^{* * * *} \\
(0.046) \\
\end{array}$ & $\begin{array}{c}0.187 * * * * \\
(0.030) \\
\end{array}$ & $\begin{array}{c}0.101 * * * \\
(0.024) \\
\end{array}$ & $\begin{array}{c}0.346^{* * *} \\
(0.060) \\
\end{array}$ \\
\hline \multicolumn{13}{|l|}{ Sector of activity } \\
\hline Industry $(\mathrm{E}+\mathrm{D}+\mathrm{F})$ & $\begin{array}{c}-0.398 * * * \\
(0.028)\end{array}$ & $\begin{array}{c}-0.340 * * * \\
(0.017)\end{array}$ & $\begin{array}{c}-0.634 * * * * \\
(0.086)\end{array}$ & $\begin{array}{c}-0.531 * * * \\
(0.012)\end{array}$ & $\begin{array}{c}-0.398^{* * *} \\
(0.021)\end{array}$ & $\begin{array}{c}-0.671 * * * \\
(0.014)\end{array}$ & $\begin{array}{c}-0.591 * * * \\
(0.015)\end{array}$ & $\begin{array}{c}-0.468 * * * \\
(0.069)\end{array}$ & $\begin{array}{c}-0.621^{* * *} \\
(0.023)\end{array}$ & $\begin{array}{c}-0.707 * * * * \\
(0.014)\end{array}$ & $\begin{array}{c}-0.425^{* * *} \\
(0.029)\end{array}$ & $\begin{array}{c}-0.833^{* * *} \\
(0.036)\end{array}$ \\
\hline Other services $(\mathrm{G}+\mathrm{H}+\mathrm{J}+\mathrm{K})$ & $\begin{array}{c}-0.350^{* * *} \\
(0.025)\end{array}$ & $\begin{array}{c}-0.328 * * * \\
(0.018)\end{array}$ & $\begin{array}{c}-0.460 * * * \\
(0.063)\end{array}$ & $\begin{array}{c}-0.483^{* * *} \\
(0.010)\end{array}$ & $\begin{array}{c}-0.297 * * * \\
(0.014)\end{array}$ & $\begin{array}{c}-0.649 * * * \\
(0.014)\end{array}$ & $\begin{array}{c}-0.558^{* * *} \\
(0.013)\end{array}$ & $\begin{array}{c}-0.439 * * * \\
(0.065)\end{array}$ & $\begin{array}{c}-0.621 * * * \\
(0.017)\end{array}$ & $\begin{array}{c}-0.589 * * * \\
(0.012)\end{array}$ & $\begin{array}{c}-0.359 * * * \\
(0.026)\end{array}$ & $\begin{array}{c}-0.654 * * * \\
(0.027)\end{array}$ \\
\hline Transportation (I) & $\begin{array}{l}-0.009 \\
(0.014)\end{array}$ & $\begin{array}{c}0.014 \\
(0.015)\end{array}$ & $\begin{array}{c}-0.135 * * * \\
(0.045)\end{array}$ & $\begin{array}{c}-0.165^{* * *} \\
(0.021)\end{array}$ & $\begin{array}{c}-0.116^{* * *} \\
(0.012)\end{array}$ & $\begin{array}{c}-0.142^{* *} \\
(0.057)\end{array}$ & $\begin{array}{l}-0.017 \\
(0.013)\end{array}$ & $\begin{array}{c}-0.029 * * \\
(0.014)\end{array}$ & $\begin{array}{l}-0.017 \\
(0.026)\end{array}$ & $\begin{array}{c}-0.148^{* * *} \\
(0.017)\end{array}$ & $\begin{array}{c}-0.086^{* * *} \\
(0.014)\end{array}$ & $\begin{array}{c}-0.173^{* * *} \\
(0.031)\end{array}$ \\
\hline Public administration and defense (L) & $\begin{array}{c}0.242^{* * *} \\
(0.026) \\
\end{array}$ & $\begin{array}{c}0.220 * * * \\
(0.023) \\
\end{array}$ & $\begin{array}{c}0.304 * * * \\
(0.052) \\
\end{array}$ & $\begin{array}{c}0.431 * * * \\
(0.031) \\
\end{array}$ & $\begin{array}{c}0.311 * * * \\
(0.050)\end{array}$ & $\begin{array}{c}0.433^{* * *} \\
(0.022) \\
\end{array}$ & $\begin{array}{c}0.417^{* * *} \\
(0.016) \\
\end{array}$ & $\begin{array}{c}0.352^{* * *} \\
(0.056)\end{array}$ & $\begin{array}{c}0.430^{* * *} * \\
(0.021) \\
\end{array}$ & $\begin{array}{c}0.526^{* * *} * \\
(0.038) \\
\end{array}$ & $\begin{array}{c}0.290^{* * *} \\
(0.025) \\
\end{array}$ & $\begin{array}{c}0.626^{* * *} \\
(0.059) \\
\end{array}$ \\
\hline Hourly wages & & & & & & & & & & & & \\
\hline Net hourly wages & $\begin{array}{c}0.001 * * * \\
(0.000)\end{array}$ & $\begin{array}{c}0.001 * * * \\
(0.000)\end{array}$ & $\begin{array}{c}0.001 * * * \\
(0.000)\end{array}$ & $\begin{array}{c}0.003^{* * *} \\
(0.000)\end{array}$ & $\begin{array}{c}0.001 * * * \\
(0.000)\end{array}$ & $\begin{array}{c}0.006 * * * \\
(0.001) \\
\end{array}$ & $\begin{array}{c}0.002^{* * *} \\
(0.000) \\
\end{array}$ & $\begin{array}{c}0.002 * * * \\
(0.000) \\
\end{array}$ & $\begin{array}{c}0.003^{* * *} * \\
(0.000)\end{array}$ & $\begin{array}{c}0.012^{* * *} \\
(0.001) \\
\end{array}$ & $\begin{array}{c}0.005 * * * \\
(0.001)\end{array}$ & $\begin{array}{c}0.022^{* * *} \\
(0.002)\end{array}$ \\
\hline Observations & 17,990 & 8,429 & 9,561 & 10,752 & 5,442 & 5,310 & 51,163 & 23,825 & 27,338 & 56,075 & 28,536 & 27,539 \\
\hline
\end{tabular}

\begin{tabular}{|c|c|c|c|c|c|c|c|c|c|c|c|c|}
\hline \multirow{2}{*}{ Selection equation - Probability to work } & \multicolumn{3}{|c|}{ BELGIUM } & \multicolumn{3}{|c|}{ DENMARK (probit model) } & \multicolumn{3}{|c|}{ FRANCE } & \multicolumn{3}{|c|}{ GERMANY } \\
\hline & All & Men & Women & All & Men & Women & All & Men & Women & All & Men & Women \\
\hline \multicolumn{13}{|l|}{ Demographics } \\
\hline Female & $\begin{array}{c}-0.300^{* * *} \\
(0.008)\end{array}$ & & & & & & $\begin{array}{c}-0.231 * * * \\
(0.004)\end{array}$ & & & $\begin{array}{c}-0.190^{* * *} \\
(0.006)\end{array}$ & & \\
\hline Age & $\begin{array}{c}-0.009 * * * \\
(0.000)\end{array}$ & $\begin{array}{c}-0.006 * * * \\
(0.001)\end{array}$ & $\begin{array}{c}-0.010^{* * *} \\
(0.001)\end{array}$ & & & & $\begin{array}{l}-0.000 \\
(0.000)\end{array}$ & $\begin{array}{c}-0.002 * * * \\
(0.000)\end{array}$ & $\begin{array}{c}0.001 * * * \\
(0.000)\end{array}$ & $\begin{array}{c}-0.005^{* * *} \\
(0.000)\end{array}$ & $\begin{array}{c}-0.006 * * * \\
(0.000)\end{array}$ & $\begin{array}{c}-0.005 * * * \\
(0.001)\end{array}$ \\
\hline Married & $\begin{array}{c}0.071 \text { *** } \\
(0.015)\end{array}$ & $\begin{array}{c}0.089 * * * \\
(0.017)\end{array}$ & $\begin{array}{l}-0.002 \\
(0.022)\end{array}$ & & & & $\begin{array}{c}0.072^{* * *} \\
(0.009)\end{array}$ & $\begin{array}{c}0.145^{* * *} \\
(0.011)\end{array}$ & $\begin{array}{c}-0.030^{* *} \\
(0.012)\end{array}$ & $\begin{array}{c}0.034^{* * *} \\
(0.011)\end{array}$ & $\begin{array}{c}0.128 * * * \\
(0.014)\end{array}$ & $\begin{array}{c}-0.103^{* * * *} \\
(0.016)\end{array}$ \\
\hline Children & $\begin{array}{c}0.170^{* * *} \\
(0.017)\end{array}$ & $\begin{array}{c}0.178^{* * *} \\
(0.022)\end{array}$ & $\begin{array}{c}0.081 * * * \\
(0.023)\end{array}$ & & & & $\begin{array}{c}0.187 * * * \\
(0.008)\end{array}$ & $\begin{array}{c}0.228 * * * \\
(0.011)\end{array}$ & $\begin{array}{c}0.089 * * * \\
(0.011)\end{array}$ & $\begin{array}{l}-0.009 \\
(0.014)\end{array}$ & $\begin{array}{c}0.094 * * * \\
(0.018)\end{array}$ & $\begin{array}{c}-0.154 * * * \\
(0.019)\end{array}$ \\
\hline Married*Children & $\begin{array}{c}-0.093 * * * \\
(0.021) \\
\end{array}$ & $\begin{array}{c}-0.051^{* *} * \\
(0.025)\end{array}$ & $\begin{array}{c}-0.069 * * \\
(0.029) \\
\end{array}$ & & & & $\begin{array}{c}-0.106 * * * \\
(0.011)\end{array}$ & $\begin{array}{c}-0.095^{* * *} * \\
(0.015)\end{array}$ & $\begin{array}{c}-0.056 * * * \\
(0.015) \\
\end{array}$ & $\begin{array}{r}-0.012 \\
(0.017) \\
\end{array}$ & $\begin{array}{l}-0.035 \\
(0.022) \\
\end{array}$ & $\begin{array}{l}0.052^{* *} \\
(0.024) \\
\end{array}$ \\
\hline \multicolumn{13}{|l|}{ Education } \\
\hline Recognised third level education (ISCED 5-7) & $\begin{array}{c}0.322 * * * \\
(0.009)\end{array}$ & $\begin{array}{c}0.151 \text { *** } \\
(0.011)\end{array}$ & $\begin{array}{c}0.457^{* * *} \\
(0.013)\end{array}$ & & & & $\begin{array}{c}0.169 * * * \\
(0.005)\end{array}$ & $\begin{array}{c}0.066^{* * *} \\
(0.007)\end{array}$ & $\begin{array}{c}0.240^{* * *} \\
(0.008)\end{array}$ & $\begin{array}{c}0.242^{* * *} \\
(0.007)\end{array}$ & $\begin{array}{c}0.189 * * * \\
(0.008)\end{array}$ & $\begin{array}{c}0.280 * * * \\
(0.011)\end{array}$ \\
\hline $\begin{array}{l}\text { Second stage of secondary level education } \\
\text { (ISCED 3) }\end{array}$ & $\begin{array}{c}0.145^{* * * *} \\
(0.010)\end{array}$ & $\begin{array}{c}0.095^{* * *} \\
(0.011)\end{array}$ & $\begin{array}{c}0.179 * * * \\
(0.015)\end{array}$ & & & & $\begin{array}{c}0.104^{* * *} \\
(0.005)\end{array}$ & $\begin{array}{c}0.042^{* * *} \\
(0.007)\end{array}$ & $\begin{array}{c}0.149 * * * \\
(0.008)\end{array}$ & $\begin{array}{c}0.133^{* * *} \\
(0.009)\end{array}$ & $\begin{array}{c}0.126^{* * *} \\
(0.012)\end{array}$ & $\begin{array}{c}0.137 * * * \\
(0.011)\end{array}$ \\
\hline \multicolumn{13}{|l|}{ Regional variables } \\
\hline Participation rate & $\begin{array}{c}0.019^{* * *} \\
(0.002)\end{array}$ & $\begin{array}{c}0.011^{* * *} \\
(0.002)\end{array}$ & $\begin{array}{c}0.017^{* * *} \\
(0.003)\end{array}$ & & & & $\begin{array}{c}0.012^{* * *} \\
(0.001)\end{array}$ & $\begin{array}{c}0.006 * * * \\
(0.001)\end{array}$ & $\begin{array}{c}0.017^{* * *} \\
(0.001)\end{array}$ & $\begin{array}{c}0.003^{* * *} \\
(0.001)\end{array}$ & $\begin{array}{c}-0.005 * * * \\
(0.001)\end{array}$ & $\begin{array}{c}0.012 * * * \\
(0.001)\end{array}$ \\
\hline Average age & $\begin{array}{c}0.001 \\
(0.018) \\
\end{array}$ & $\begin{array}{l}-0.019 \\
(0.020) \\
\end{array}$ & $\begin{array}{c}0.029 \\
(0.026) \\
\end{array}$ & & & & $\begin{array}{c}-0.011 \text { *** } \\
(0.004) \\
\end{array}$ & $\begin{array}{c}-0.018^{* * *} \\
(0.005) \\
\end{array}$ & $\begin{array}{r}-0.003 \\
(0.006) \\
\end{array}$ & $\begin{array}{c}-0.014^{* * *} * \\
(0.005) \\
\end{array}$ & $\begin{array}{c}-0.021 * * * \\
(0.006) \\
\end{array}$ & $\begin{array}{c}-0.011 * \\
(0.007) \\
\end{array}$ \\
\hline Observations & 17,990 & 8,429 & 9,561 & & & & 51,163 & 23,825 & 27,338 & 56,075 & 28,536 & 27,539 \\
\hline Rho & $\begin{array}{c}0.648 \\
(0.082)\end{array}$ & $\begin{array}{l}0.881 \\
(0.041)\end{array}$ & $\begin{array}{c}0.358 \\
(0.161)\end{array}$ & & & & $\begin{array}{l}-0.195 \\
(0.032) \\
\end{array}$ & $\begin{array}{l}-0.178 \\
(0.411)\end{array}$ & $\begin{array}{c}0.002 \\
(0.000)\end{array}$ & $\begin{array}{l}-0.645 \\
(0.073)\end{array}$ & $\begin{array}{l}0.092 \\
(0.183)\end{array}$ & $\begin{array}{l}-0.622 \\
(0.073)\end{array}$ \\
\hline Wald test for Rho=0 (Prob.) & 0.000 & 0.000 & 0.042 & & & & 0.000 & 0.672 & $\begin{array}{l}\text { convergence } \\
\text { not achieved }\end{array}$ & 0.000 & 0.617 & 0.000 \\
\hline
\end{tabular}

1. Robust weighted standard errors in parenthesis

2. All estimations include year dummies not reported here

3. Base categories for dummy variables: Education: less than 2nd stage of secondary education, Part time contract, Legislators, senior officials and managers, Educ. and Health\&Social Work 
Table 4 (cont.) Estimation of the probability of working in the PS (ECHP, all waves) - Heckman Probit procedure

\begin{tabular}{|c|c|c|c|c|c|c|c|c|c|c|c|c|}
\hline \multirow{2}{*}{ Outrome equation - Probability to work in the public sector } & \multicolumn{3}{|c|}{ GREECE*'(probit model) } & \multicolumn{3}{|c|}{ IRELAND } & \multicolumn{3}{|c|}{ ITALY } & \multicolumn{3}{|c|}{$\begin{array}{l}\text { NETHERLANDS }^{5} \text { (probit model) } \\
\end{array}$} \\
\hline & All & Men & Women & All & Men & Women & All & Men & Women & All & Men & Women \\
\hline \multicolumn{13}{|l|}{ Demographics } \\
\hline Female & $\begin{array}{l}-0.010 \\
0.008\end{array}$ & & & $\begin{array}{c}0.104 * * \\
(0.034)\end{array}$ & & & $\begin{array}{c}-0.035^{* * *} \\
(0.005)\end{array}$ & & & $\begin{array}{l}-0.019 * * \\
(0.008)\end{array}$ & & \\
\hline Age & $\begin{array}{c}0.005 * k * \\
(0.000)\end{array}$ & $\begin{array}{c}0.004 * * * \\
(0.000)\end{array}$ & $\begin{array}{c}0.005 * * * \\
(0.001)\end{array}$ & $\begin{array}{c}0.003 * * * \\
(0.001)\end{array}$ & $\begin{array}{c}0.003^{* * *} \\
(0.001)\end{array}$ & $\begin{array}{l}-0.000 \\
(0.001)\end{array}$ & $\begin{array}{c}0.002 * * * \\
(0.000)\end{array}$ & $\begin{array}{c}0.002 * * * \\
(0.000)\end{array}$ & $\begin{array}{c}0.005 * * * \\
(0.001)\end{array}$ & $\begin{array}{c}0.002^{2 * * *} \\
(0.000)\end{array}$ & $\begin{array}{c}0.003 * * * \\
(0.000)\end{array}$ & $\begin{array}{l}0.001 \\
(0.001)\end{array}$ \\
\hline \multirow[t]{2}{*}{ Married } & 0.017 & $0.055^{* * *}$ & $-0.052^{*}$ & -0.013 & $0.041^{*}$ & 0.020 & $0.023^{* * *}$ & $0.045^{* * *}$ & -0.008 & -0.011 & -0.012 & -0.005 \\
\hline & $(0.014)$ & $(0.015)$ & $(0.028)$ & $(0.030)$ & $(0.024)$ & $(0.015)$ & $(0.007)$ & $(0.007)$ & $(0.017)$ & $(0.010)$ & $(0.012)$ & $(0.016)$ \\
\hline \multirow[t]{2}{*}{ Children } & $0.066^{* * * *}$ & 0.008 & $0.053^{* *}$ & -0.042 & -0.069 & -0.021 & $0.047 * * *$ & 0.000 & $0.070^{* * *}$ & -0.015 & -0.004 & -0.004 \\
\hline & $(0.018)$ & $(0.057)$ & $(0.023)$ & $(0.032)$ & $(0.044)$ & $(0.022)$ & $(0.010)$ & $(0.023)$ & $(0.018)$ & $(0.016)$ & $(0.016)$ & $(0.026)$ \\
\hline \multirow[t]{2}{*}{ Married ${ }^{C}$ Children } & $-0.050 * *$ & -0.007 & -0.003 & 0.056 & 0.065 & -0.024 & $-0.030 * *$ & 0.017 & -0.028 & -0.024 & -0.016 & -0.036 \\
\hline & $(0.024)$ & $(0.060)$ & $(0.034)$ & $(0.039)$ & $(0.046)$ & $(0.024)$ & $(0.012)$ & $(0.024)$ & $(0.024)$ & $(0.017)$ & $(0.019)$ & $(0.029)$ \\
\hline \multicolumn{13}{|l|}{ Education } \\
\hline Recognised third level education (ISCED 5-7) & 0.096 ***; & $0.122 * * *$ & $\begin{array}{r}-0.010 \\
0.021\end{array}$ & $-0.126^{* * *}$ & -0.005 & 0.017 & $0.103^{* * *}$ & $0.112^{* * *}$ & $0.091 * * k$ & $0.024 * x$ & $0.033^{* *}$ & 0.007 \\
\hline \multirow{2}{*}{$\begin{array}{l}\text { Second stage of secondary level education } \\
\text { (ISCED 3) }\end{array}$} & $\begin{array}{l}(0.013) \\
0.105 * * *\end{array}$ & $\begin{array}{l}(0.016) \\
0.131 * *\end{array}$ & $\begin{array}{l}(0.021) \\
-0.004\end{array}$ & $\begin{array}{l}(0.039) \\
-0.074^{* *}\end{array}$ & $\begin{array}{c}(0.026) \\
0.021\end{array}$ & $\begin{array}{c}(0.043) \\
0.017\end{array}$ & $\begin{array}{c}(0.012) \\
0.053 * *\end{array}$ & $\begin{array}{c}(0.014) \\
0.028 * *\end{array}$ & $\begin{array}{c}(0.026) \\
0.095^{* * *}\end{array}$ & $\begin{array}{l}(0.012) \\
-0.014\end{array}$ & $\begin{array}{l}(0.015) \\
-0.000\end{array}$ & $\begin{array}{c}(0.019) \\
-0.036^{* *}\end{array}$ \\
\hline & $(0.010)$ & $(0.012)$ & $(0.019)$ & $(0.029)$ & $(0.015)$ & $(0.022)$ & $(0.006)$ & $(0.005)$ & $(0.016)$ & $(0.010)$ & $(0.013)$ & $(0.017)$ \\
\hline \multicolumn{13}{|l|}{ Labour market } \\
\hline Working hours & $\begin{array}{l}-0.003^{* * *} \\
(0.000)\end{array}$ & $\begin{array}{c}-0.005^{* * *} \\
(0.000)\end{array}$ & $\begin{array}{l}0.001 \\
(0.001)\end{array}$ & $\begin{array}{c}0.001 \\
(0.001)\end{array}$ & $\begin{array}{l}-0.001 \\
(0.001)\end{array}$ & $\begin{array}{c}0.001 * * \\
(0.001)\end{array}$ & $\begin{array}{c}-0.002^{* * *} \\
(0.000)\end{array}$ & $\begin{array}{c}-0.003^{* * *} \\
(0.000)\end{array}$ & $\begin{array}{c}0.002^{* * *} \\
(0.001)\end{array}$ & $\begin{array}{c}-0.003^{* * *} \\
(0.000)\end{array}$ & $\begin{array}{c}-0.006 * * * \\
(0.000)\end{array}$ & $\begin{array}{l}-0.001 \\
(0.001)\end{array}$ \\
\hline \multicolumn{13}{|l|}{ Satisfaction in terms of (1-minimum; 6-maximum): } \\
\hline Working conditions/environment & $\begin{array}{c}0.005^{* *} \\
(0.003)\end{array}$ & $\begin{array}{c}0.010^{* * * *} \\
(0.003)\end{array}$ & $\begin{array}{l}0.001 \\
(0.005)\end{array}$ & $\begin{array}{c}0.003^{* *} \\
(0.001)\end{array}$ & $\begin{array}{l}0.002^{*} \\
(0.001)\end{array}$ & $\begin{array}{c}.003^{* *} \\
(0.001)\end{array}$ & $\begin{array}{l}-0.000 \\
(0.001)\end{array}$ & $\begin{array}{l}-0.000 \\
(0.001)\end{array}$ & $\begin{array}{l}-0.000 \\
(0.003)\end{array}$ & $\begin{array}{c}-0.013^{* * *} \\
(0.002)\end{array}$ & $\begin{array}{c}-0.006 * * \\
(0.003)\end{array}$ & $\begin{array}{c}-0.019 * * * * \\
(0.004)\end{array}$ \\
\hline \multicolumn{13}{|l|}{ Occupation } \\
\hline Professionals & $\begin{array}{c}0.123 * * * * \\
(0.022)\end{array}$ & $\begin{array}{c}0.097 * * * \\
(0.025)\end{array}$ & $\begin{array}{c}0.206 * * * \\
(0.052)\end{array}$ & $\begin{array}{c}0.267 * * * \\
(0.030)\end{array}$ & $\begin{array}{c}0.194 * * * \\
(0.029)\end{array}$ & $\begin{array}{c}0.095 * \\
(0.037)\end{array}$ & $\begin{array}{c}0.133 * * * \\
(0.017)\end{array}$ & $\begin{array}{c}0.055^{* * *} \\
(0.014)\end{array}$ & $\begin{array}{c}0.311 * * * \\
(0.055)\end{array}$ & $\begin{array}{c}0.080 * * * \\
(0.013)\end{array}$ & $\begin{array}{c}0.041 * * \\
(0.014)\end{array}$ & $\begin{array}{c}0.140 * * * * \\
(0.029)\end{array}$ \\
\hline Technicians and associate professionals & $\begin{array}{c}0.087^{* * *} \\
(0.023)\end{array}$ & $\begin{array}{c}-0.043 * * \\
(0.019)\end{array}$ & $\begin{array}{c}0.354 * * * \\
(0.057)\end{array}$ & $\begin{array}{c}0.180 * * * \\
(0.036)\end{array}$ & $\begin{array}{c}0.105 * * * \\
(0.023)\end{array}$ & $\begin{array}{c}0.086 * \\
(0.036)\end{array}$ & $\begin{array}{c}0.098 * * * \\
(0.015)\end{array}$ & $\begin{array}{c}0.041 * * \\
(0.013)\end{array}$ & $\begin{array}{c}0.255^{* * *} \\
(0.052)\end{array}$ & $\begin{array}{c}-0.044 * * * \\
(0.011)\end{array}$ & $\begin{array}{c}-0.046 * * * \\
(0.011)\end{array}$ & $\begin{array}{l}-0.031 \\
(0.024)\end{array}$ \\
\hline Clerks & $0.214 * * * *$ & $0.191 * * *$ & $0.310 * * *$ & $0.234 * * *$ & $0.224 * * *$ & $0.068 * *$ & $0.082 * * *$ & $0.056^{* * *}$ & $0.168^{* * * *}$ & -0.021 & $-0.033^{* *}$ & -0.001 \\
\hline $\begin{array}{l}\text { Service workers and shop and market sales } \\
\text { workers }\end{array}$ & $\begin{array}{l}0.020 \\
(0.018)\end{array}$ & $\begin{array}{l}0.014 \\
(0.018)\end{array}$ & $\begin{array}{l}0.083^{*} \\
(0.047)\end{array}$ & $\begin{array}{c}0.140 * * * \\
(0.030)\end{array}$ & $\begin{array}{c}0.118^{* * *} \\
(0.025)\end{array}$ & $\begin{array}{l}0.020 \\
(0.025)\end{array}$ & $\begin{array}{c}0.066^{* * *} \\
(0.016)\end{array}$ & $\begin{array}{c}0.029 * * \\
(0.014)\end{array}$ & $\begin{array}{c}0.188^{* * *} \\
(0.051)\end{array}$ & $-0.066^{* * *}$ & $\begin{array}{l}-0.007 \\
0.016\end{array}$ & $\begin{aligned}-0.074^{* * *+}+4 \\
(0.025)\end{aligned}$ \\
\hline $\begin{array}{l}\text { Craft and related trade workers }+ \text { skilled } \\
\text { workers }\end{array}$ & $\begin{array}{c}0.096^{* * * *} \\
(0.021)\end{array}$ & $\begin{array}{c}0.060^{* * *} \\
(0.019)\end{array}$ & $\begin{array}{l}0.107 * \\
(0.059)\end{array}$ & $\begin{array}{c}0.128 * * * \\
(0.032)\end{array}$ & $\begin{array}{c}0.099 * * * \\
(0.023)\end{array}$ & $\begin{array}{l}0.001 \\
(0.059)\end{array}$ & $\begin{array}{c}0.053^{* * *} \\
(0.015)\end{array}$ & $\begin{array}{r}0.032^{* *} \\
(0.013)\end{array}$ & $\begin{array}{l}0.052 \\
(0.050)\end{array}$ & $-0.040 * * *$ & $-0.038^{* * *}$ & $-0.075^{*}$ \\
\hline Plant and machine operators and assemblers & $0.077^{\text {**** }}$ & $\begin{array}{l}0.050^{* *} \\
(0.020)\end{array}$ & -0.028 & $\begin{array}{l}0.040 \\
(0.030)\end{array}$ & $\begin{array}{c}0.055 * * \\
(0.023)\end{array}$ & $-0.120^{*}$ & $\begin{array}{c}0.056 \text { *** } \\
(0.015)\end{array}$ & $0.031 * *$ & $0.133 * *$ & $-0.048^{* * *}$ & $-0.041^{* * * *}$ & $-0.090^{*}$ \\
\hline Elementary occupations & $\begin{array}{c}0.162 * * * \\
(0.024)\end{array}$ & $\begin{array}{c}0.154^{* * * *} \\
(0.028)\end{array}$ & $\begin{array}{c}0.219 * * * \\
(0.055)\end{array}$ & $\begin{array}{c}0.248^{* * *} \\
(0.034)\end{array}$ & $\begin{array}{c}0.208 * * * \\
(0.028)\end{array}$ & $\begin{array}{l}0.060^{*} \\
(0.035)\end{array}$ & $\begin{array}{c}0.040^{* * * *} \\
(0.015)\end{array}$ & $\begin{array}{c}0.036^{* * *} \\
(0.014)\end{array}$ & $\begin{array}{c}0.096 * * \\
(0.048)\end{array}$ & $\begin{array}{l}0.019 \\
(0.018)\end{array}$ & $\begin{array}{c}0.043^{* *} \\
(0.021)\end{array}$ & $\begin{array}{l}-0.021 \\
(0.032)\end{array}$ \\
\hline $\begin{array}{l}\text { Sector of activity } \\
\end{array}$ & & & & & & & & & & & & \\
\hline Industry $(\mathrm{E}+\mathrm{D}+\mathrm{F})$ & $\begin{array}{c}-0.239 * * * \\
(0.007)\end{array}$ & $\begin{array}{c}-0.215^{* * *} \\
(0.011)\end{array}$ & $\begin{array}{c}-0.235 * * * \\
(0.009)\end{array}$ & $\begin{array}{c}-0.513 * * * \\
(0.022)\end{array}$ & $\begin{array}{c}-0.298 * * * \\
(0.023)\end{array}$ & $\begin{array}{c}-0.388 * * * \\
(0.119)\end{array}$ & $\begin{array}{c}-0.272^{* * *} \\
(0.020)\end{array}$ & $\begin{array}{c}-0.224 * * * \\
(0.013)\end{array}$ & $\begin{array}{c}-0.395^{* * *} \\
(0.042)\end{array}$ & $\begin{array}{c}-0.278 * * * \\
(0.005)\end{array}$ & $\begin{array}{c}-0.268 * * * \\
(0.008)\end{array}$ & $\begin{array}{c}-0.298 * *+* \\
(0.008)\end{array}$ \\
\hline Other services $(\mathrm{G}+\mathrm{H}+\mathrm{J}+\mathrm{K})$ & $\begin{array}{c}-0.259 * * * \\
(0.007)\end{array}$ & $\begin{array}{c}-0.222^{* * *} \\
(0.009)\end{array}$ & $\begin{array}{c}-0.303 * * * \\
(0.012)\end{array}$ & $\begin{array}{c}-0.571 * * * \\
(0.023)\end{array}$ & $\begin{array}{c}-0.368^{* * *} \\
(0.028)\end{array}$ & $\begin{array}{c}-0.337 * * * \\
(0.110)\end{array}$ & $\begin{array}{c}-0.302^{* * *} \\
(0.021)\end{array}$ & $\begin{array}{c}-0.249 * * * \\
(0.014)\end{array}$ & $\begin{array}{c}-0.444^{* * *} \\
(0.045)\end{array}$ & $\begin{array}{c}-0.369^{* * *} \\
(0.005)\end{array}$ & $\begin{array}{c}-0.317^{* * *} \\
(0.007)\end{array}$ & $\begin{array}{c}-0.447 * * * k \\
(0.009)\end{array}$ \\
\hline Transportation (I) & $-0.088^{* * *}$ & $-0.054^{* * *}$ & $-0.108^{* * *}$ & $0.049 * *$ & $0.070^{* * * *}$ & -0.041 & $-0.057^{* * * *}$ & $-0.046^{* * *}$ & $-0.084^{* * * *}$ & $-0.191^{* * *}$ & $-0.152^{* * *}$ & $-0.257^{* * * *}$ \\
\hline & $(0.009)$ & $(0.012)$ & $(0.017)$ & $(0.023)$ & $(0.020)$ & $(0.026)$ & $(0.008)$ & $(0.007)$ & $(0.022)$ & $(0.004)$ & $(0.005)$ & $(0.008)$ \\
\hline Public administration and defense $(\mathrm{L})$ & $0.585^{\mathrm{k} * \mathrm{k}}$ & $0.643^{* * *}$ & $0.516^{* * *}$ & $0.409 * * *$ & $0.304 * * *$ & $0.209 * k *$ & $0.240 \mathrm{k} * \mathrm{k}$ & $0.183^{* * *}$ & $0.398^{* * * *}$ & $0.442 * * *$ & $0.352^{* * *}$ & $0.516^{* * *}$ \\
\hline & $(0.024)$ & $(0.030)$ & $(0.040)$ & $(0.038)$ & $(0.035)$ & $(0.071)$ & $(0.021)$ & $(0.017)$ & $(0.046)$ & $(0.018)$ & $(0.024)$ & $(0.025)$ \\
\hline Hourly wages & & & & & & & & & & & & \\
\hline Net hourly wages & $\begin{array}{c}.000^{* * * *} \\
(0.000)\end{array}$ & $\begin{array}{c}0.000^{* * *} * \\
(0.000)\end{array}$ & $\begin{array}{c}0.000^{* * *} \\
(0.000)\end{array}$ & $\begin{array}{c}0.068^{* * *} \\
(0.006)\end{array}$ & $\begin{array}{c}0.039 * * * \\
(0.005)\end{array}$ & $\begin{array}{c}0.046^{* * *} * \\
(0.016)\end{array}$ & $\begin{array}{c}0.015^{* * * *} \\
(0.001)\end{array}$ & $\begin{array}{c}0.010^{* * *} \\
(0.001)\end{array}$ & $\begin{array}{c}0.033 * * * \\
(0.004)\end{array}$ & $\begin{array}{c}0.002 * * * \\
(0.000)\end{array}$ & $\begin{array}{c}0.001^{* * *} \\
(0.000)\end{array}$ & $\begin{array}{c}0.008^{* * *} \\
(0.001)\end{array}$ \\
\hline Observations & 27,892 & 17,837 & 10,055 & 27,214 & 12,792 & 14,422 & 82,045 & 39,710 & 42,335 & 30,597 & 17,808 & 12,789 \\
\hline
\end{tabular}

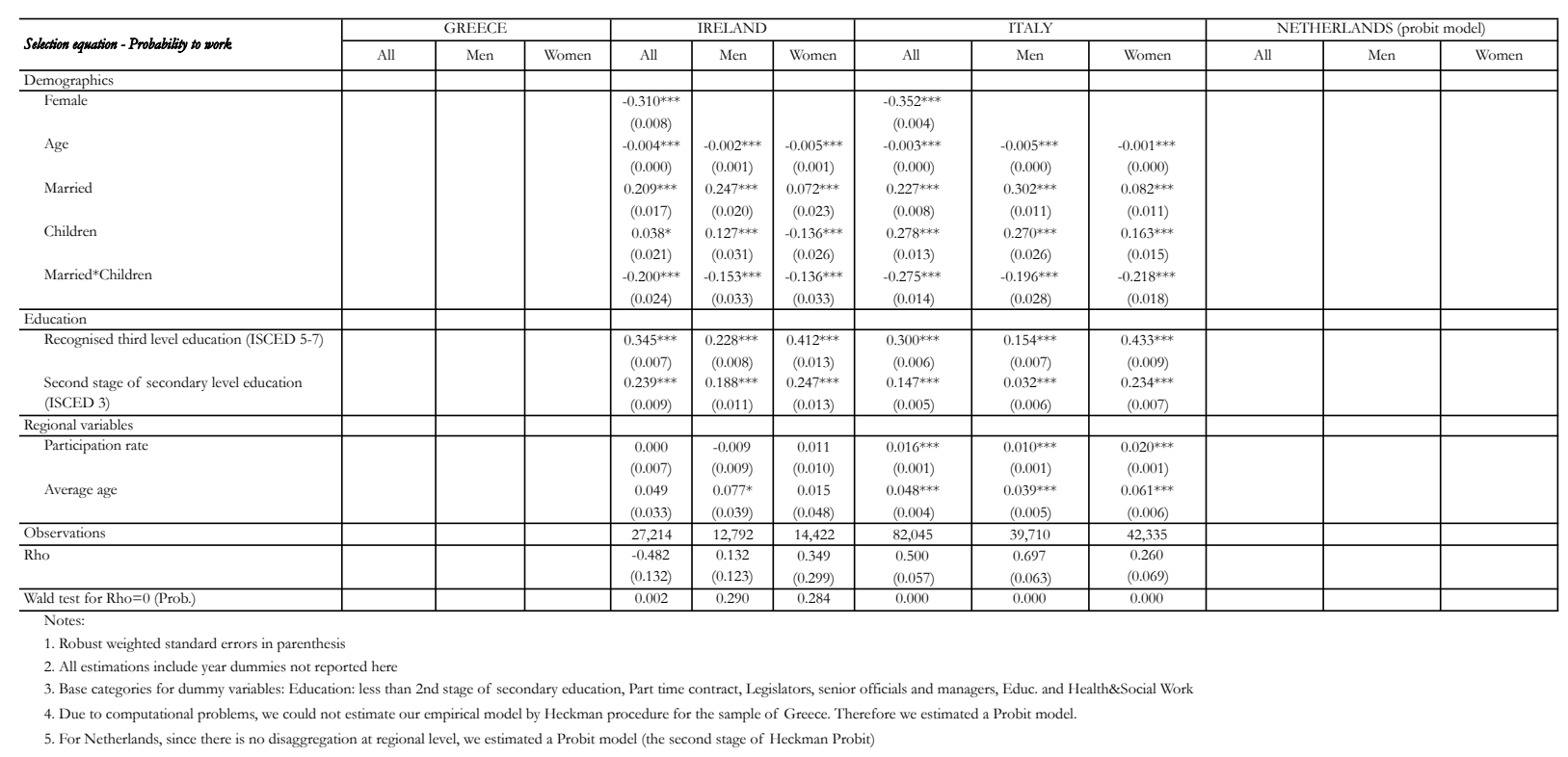


Table 4 (cont.) Estimation of the probability of working in the PS (ECHP, all waves) - Heckman Probit procedure

\begin{tabular}{|c|c|c|c|c|c|c|c|c|c|c|c|c|c|}
\hline \multirow{2}{*}{\multicolumn{2}{|c|}{ Outcome equation - Probability to work in the public sector }} & \multicolumn{3}{|c|}{ PORTUGAL } & \multicolumn{3}{|c|}{ SPAIN } & \multicolumn{3}{|c|}{ SWEDEN } & \multicolumn{3}{|c|}{ UNITED KINGDOM } \\
\hline & & All & Men & Women & All & Men & Women & All & Men & Women & All & Men & Women \\
\hline \multicolumn{14}{|l|}{ Demographics } \\
\hline & Female & $\begin{array}{l}0.065^{* * *} \\
(0.017)\end{array}$ & & & $\begin{array}{l}-0.029 * * * \\
(0.009)\end{array}$ & & & $\begin{array}{c}0.052^{* * *} \\
(0.010)\end{array}$ & & & $\begin{array}{l}0.004 \\
(0.006)\end{array}$ & & \\
\hline & Age & $\begin{array}{c}0.004^{* * *} \\
(0.001)\end{array}$ & $\begin{array}{c}0.002^{* * *} \\
(0.000)\end{array}$ & $\begin{array}{c}-0.001^{1 * * *} \\
(0.000)\end{array}$ & $\begin{array}{c}0.001^{* * *} \\
(0.000)\end{array}$ & $\begin{array}{l}0.000^{*} \\
(0.000)\end{array}$ & $\begin{array}{c}0.001 * * * \\
(0.000)\end{array}$ & $\begin{array}{c}0.003^{* * *} \\
(0.000)\end{array}$ & $\begin{array}{c}0.002^{* * *} \\
(0.000)\end{array}$ & $\begin{array}{c}0.006^{* * *} \\
(0.001)\end{array}$ & $\begin{array}{c}0.001 * * * \\
(0.000)\end{array}$ & $\begin{array}{c}0.001 * * * \\
(0.000)\end{array}$ & $\begin{array}{c}0.001 * * * \\
(0.000)\end{array}$ \\
\hline & Married & $\begin{array}{c}-0.063 * * * \\
(0.019)\end{array}$ & $\begin{array}{l}0.007 \\
(0.008)\end{array}$ & $\begin{array}{l}-0.014 \\
(0.015)\end{array}$ & $\begin{array}{l}0.013^{*} \\
(0.007)\end{array}$ & $\begin{array}{c}0.032 * * * \\
(0.007)\end{array}$ & $\begin{array}{l}-0.008 \\
(0.009)\end{array}$ & $\begin{array}{c}0.081 * * * \\
(0.014)\end{array}$ & $\begin{array}{c}0.043^{* * *} \\
(0.015)\end{array}$ & $\begin{array}{c}0.087 * * * \\
(0.031)\end{array}$ & $\begin{array}{l}0.007 \\
(0.006)\end{array}$ & $\begin{array}{l}-0.010 \\
(0.007)\end{array}$ & $\begin{array}{c}0.035 * * * \\
(0.008)\end{array}$ \\
\hline & Children & $\begin{array}{l}-0.103 * * * \\
(0.026)\end{array}$ & $\begin{array}{l}-0.012 \\
(0.014)\end{array}$ & $\begin{array}{l}-0.009 \\
(0.018)\end{array}$ & 0.009 & -0.021 & $0.020 * *$ & $0.038^{* * * *}$ & $0.019 *$ & $0.066^{* * * *}$ & $\begin{array}{r}-0.005 \\
(0.009)\end{array}$ & $\begin{array}{l}0.015 \\
(0.009)\end{array}$ & $\begin{array}{c}-0.061 * * * \\
(0.011)\end{array}$ \\
\hline & Married*Children & $0.063 * * *$ & -0.005 & 0.020 & 0.015 & $0.036^{* *}$ & $\begin{array}{l}(0.009) \\
0.003\end{array}$ & $\begin{array}{l}-0.017) \\
-0.016\end{array}$ & $-0.021^{*}$ & -0.015 & 0.016 & $\begin{array}{l}-0.009) \\
-0.003\end{array}$ & $0.070^{* * *}$ \\
\hline \multirow{2}{*}{\multicolumn{14}{|c|}{ Education }} \\
\hline & & & & & & & & & & & & & \\
\hline & Recognised third level education (ISCED 5-7) & $\begin{array}{l}-0.010 \\
(0.019)\end{array}$ & $\begin{array}{c}0.033^{* *} \\
(0.016)\end{array}$ & $\begin{array}{l}0.000 \\
(0.018)\end{array}$ & $\begin{array}{c}0.086 * * * \\
(0.009)\end{array}$ & $\begin{array}{c}0.055^{* * *} \\
(0.010)\end{array}$ & $\begin{array}{c}0.136 * * * \\
(0.017)\end{array}$ & $\begin{array}{c}0.168 * * * \\
(0.016)\end{array}$ & $\begin{array}{c}0.123 * * * \\
(0.020)\end{array}$ & $\begin{array}{c}0.197 * * * \\
(0.036)\end{array}$ & $\begin{array}{c}0.037 * * * \\
(0.005)\end{array}$ & $\begin{array}{c}0.028 * * * \\
(0.005)\end{array}$ & $\begin{array}{c}0.084 * * \\
(0.008)\end{array}$ \\
\hline & $\begin{array}{l}\text { Second stage of secondary level education } \\
\text { (ISCED 3) }\end{array}$ & $\begin{array}{c}0.038 * * * \\
(0.014)\end{array}$ & $\begin{array}{l}0.013 \\
(0.008) \\
\end{array}$ & $\begin{array}{r}-0.008 \\
(0.013) \\
\end{array}$ & $\begin{array}{c}0.039 \text { *** } \\
(0.008)\end{array}$ & $\begin{array}{c}0.025 * * * \\
(0.007)\end{array}$ & $\begin{array}{c}0.052^{* * *} \\
(0.010) \\
\end{array}$ & $\begin{array}{c}0.095^{\text {**** }} \\
(0.012)\end{array}$ & $\begin{array}{c}0.054^{* * *} \\
(0.012)\end{array}$ & $\begin{array}{c}0.114^{* * *} \\
(0.034)\end{array}$ & $\begin{array}{l}0.002 \\
(0.007) \\
\end{array}$ & $\begin{array}{l}0.001 \\
(0.007) \\
\end{array}$ & $\begin{array}{c}0.034 * * * \\
(0.009)\end{array}$ \\
\hline \multicolumn{14}{|c|}{ Labour market } \\
\hline & Working hours & $\begin{array}{c}-0.003 * * * \\
(0.000) \\
\end{array}$ & $\begin{array}{c}-0.002^{* * * *} \\
(0.000) \\
\end{array}$ & $\begin{array}{c}-0.001 * * \\
(0.000) \\
\end{array}$ & $\begin{array}{r}-0.001 * * * \\
(0.000) \\
\end{array}$ & $\begin{array}{c}-0.002 * * * \\
(0.000) \\
\end{array}$ & $\begin{array}{c}0.001 * * * \\
(0.000)\end{array}$ & $\begin{array}{c}0.000 \\
(0.000) \\
\end{array}$ & $\begin{array}{c}0.000 \\
(0.000) \\
\end{array}$ & $\begin{array}{c}0.001 \\
(0.001) \\
\end{array}$ & $\begin{array}{r}-0.000 \\
(0.000) \\
\end{array}$ & $\begin{array}{c}-0.001 * * * \\
(0.000) \\
\end{array}$ & $\begin{array}{c}0.001 * * * \\
(0.000) \\
\end{array}$ \\
\hline \multicolumn{14}{|c|}{ Satisfaction in terms of (1-minimum; 6-maximum): } \\
\hline & Working conditions/environment & $\begin{array}{l}0.002 \\
(0.002) \\
\end{array}$ & $\begin{array}{l}0.002 \\
(0.002) \\
\end{array}$ & $\begin{array}{l}0.001 \\
(0.002) \\
\end{array}$ & $\begin{array}{c}-0.004 * * * \\
(0.001) \\
\end{array}$ & $\begin{array}{l}-0.002^{* *} \\
(0.001) \\
\end{array}$ & $\begin{array}{l}-0.004 * * \\
(0.002) \\
\end{array}$ & & & & & & \\
\hline \multicolumn{14}{|l|}{ Occupation } \\
\hline & Professionals & $\begin{array}{c}0.206^{* * *} \\
(0.031)\end{array}$ & $\begin{array}{c}0.061 * * * \\
(0.015)\end{array}$ & $\begin{array}{c}0.137 * * * \\
(0.040)\end{array}$ & $\begin{array}{c}0.158^{* * *} \\
(0.027)\end{array}$ & $\begin{array}{c}0.101^{* * *} \\
(0.013)\end{array}$ & $\begin{array}{c}0.115 * * * \\
(0.024)\end{array}$ & & & & $\begin{array}{c}0.078^{* * *} \\
(0.008)\end{array}$ & $\begin{array}{l}0.043^{* * *} \\
(0.007)\end{array}$ & $\begin{array}{c}0.091 * * * \\
(0.011)\end{array}$ \\
\hline & Technicians and associate professionals & $\begin{array}{c}0.177 * * * * \\
(0.030)\end{array}$ & $\begin{array}{c}0.063 * * * \\
(0.014)\end{array}$ & $\begin{array}{l}0.090^{* *} \\
(0.037)\end{array}$ & $\begin{array}{c}0.116^{* * * *} \\
(0.021)\end{array}$ & $\begin{array}{c}0.055^{* * *} \\
(0.011)\end{array}$ & $\begin{array}{c}0.107 * * * \\
(0.022)\end{array}$ & & & & $\begin{array}{c}0.062^{* * *} \\
(0.008)\end{array}$ & $\begin{array}{l}0.012 \\
(0.007)\end{array}$ & $\begin{array}{c}0.086^{* * *} \\
(0.011)\end{array}$ \\
\hline & Clerks & $\begin{array}{c}0.186^{* * *} \\
(0.031)\end{array}$ & $\begin{array}{c}0.073^{* * *} \\
(0.014)\end{array}$ & $\begin{array}{c}0.099 * * * \\
(0.036)\end{array}$ & $\begin{array}{c}0.143^{* * *} \\
(0.024)\end{array}$ & $\begin{array}{c}0.103^{* * *} \\
(0.018)\end{array}$ & $\begin{array}{c}0.103 * * * \\
(0.021)\end{array}$ & & & & $\begin{array}{c}0.092^{* * *} \\
(0.009)\end{array}$ & $\begin{array}{c}0.113^{* * *} \\
(0.008)\end{array}$ & $\begin{array}{c}0.061 * * * \\
(0.011)\end{array}$ \\
\hline & $\begin{array}{l}\text { Service workers and shop and market sales } \\
\text { workers }\end{array}$ & $\begin{array}{c}0.111^{\text {**** }} \\
(0.031)\end{array}$ & $\begin{array}{c}0.068 * * * \\
(0.015)\end{array}$ & $\begin{array}{l}0.052 \\
(0.036)\end{array}$ & $\begin{array}{c}0.131 \text { *** } \\
(0.022)\end{array}$ & $\begin{array}{c}0.102^{* * *} \\
(0.012)\end{array}$ & $\begin{array}{c}0.099 * * * \\
(0.021)\end{array}$ & & & & $\begin{array}{c}0.040^{* * * *} \\
(0.008)\end{array}$ & $\begin{array}{c}0.036 \text { **** } \\
(0.010)\end{array}$ & $\begin{array}{c}0.057 * * * \\
(0.011)\end{array}$ \\
\hline & Craft and related trade workers + skilled workers & $\begin{array}{c}0.153^{* * *} \\
(0.031)\end{array}$ & $\begin{array}{c}0.056^{* * *} \\
(0.014)\end{array}$ & $\begin{array}{c}0.097 * * \\
(0.039)\end{array}$ & $\begin{array}{c}0.148^{* * *} \\
(0.025)\end{array}$ & $\begin{array}{c}0.095^{* * *} \\
(0.013)\end{array}$ & $\begin{array}{c}0.132 * * * \\
(0.026)\end{array}$ & & & & $\begin{array}{c}0.039 * * * \\
(0.010)\end{array}$ & $\begin{array}{c}0.026 * * * \\
(0.008)\end{array}$ & $\begin{array}{l}0.048 * \\
(0.029)\end{array}$ \\
\hline & Plant and machine operators and assemblers & $\begin{array}{c}0.130^{* * *} \\
(0.031)\end{array}$ & $\begin{array}{c}0.052^{* * *} \\
(0.014)\end{array}$ & $\begin{array}{l}0.003 \\
(0.045)\end{array}$ & $\begin{array}{c}0.111^{* * *} \\
(0.021)\end{array}$ & $\begin{array}{c}0.072^{* * *} \\
(0.013)\end{array}$ & $\begin{array}{l}0.007 \\
(0.048)\end{array}$ & & & & $\begin{array}{c}-0.053 * * * \\
(0.014)\end{array}$ & $\begin{array}{c}-0.028 * * * \\
(0.011)\end{array}$ & $\begin{array}{l}-0.036 \\
(0.041)\end{array}$ \\
\hline & Elementary occupations & $\begin{array}{c}0.123^{* * * *} \\
(0.031) \\
\end{array}$ & $\begin{array}{c}0.066^{* * *} \\
(0.015) \\
\end{array}$ & $\begin{array}{l}0.064^{*} \\
(0.036) \\
\end{array}$ & $\begin{array}{c}0.112^{* * * *} \\
(0.022)\end{array}$ & $\begin{array}{c}0.093^{* * *} \\
(0.013) \\
\end{array}$ & $\begin{array}{c}0.077^{* * *} \\
(0.020) \\
\end{array}$ & & & & $\begin{array}{c}0.106^{* * *} \\
(0.011) \\
\end{array}$ & $\begin{array}{c}0.076^{* * * *} \\
(0.010) \\
\end{array}$ & $\begin{array}{c}0.135 * * * \\
(0.015) \\
\end{array}$ \\
\hline \multicolumn{14}{|l|}{ Sector of activity } \\
\hline & Industry $(\mathrm{E}+\mathrm{D}+\mathrm{F})$ & $\begin{array}{c}-0.363 * * * \\
(0.023)\end{array}$ & $\begin{array}{c}-0.159 * * * \\
(0.016)\end{array}$ & $\begin{array}{c}-0.295 * * * \\
(0.037)\end{array}$ & $\begin{array}{c}-0.204 * * * \\
(0.035)\end{array}$ & $\begin{array}{l}-0.162 * * * \\
(0.015)\end{array}$ & $\begin{array}{c}-0.193 * * * \\
(0.028)\end{array}$ & $\begin{array}{l}-0.530 * * * \\
(0.033)\end{array}$ & $\begin{array}{l}-0.269 * * * \\
(0.029)\end{array}$ & $\begin{array}{l}-1.058 * * * \\
(0.085)\end{array}$ & $\begin{array}{c}-0.355 \text { *** } \\
(0.019)\end{array}$ & $\begin{array}{c}-0.210^{0 * * *} \\
(0.010)\end{array}$ & $\begin{array}{c}-0.418^{* * *} \\
(0.019)\end{array}$ \\
\hline & Other services $(\mathrm{G}+\mathrm{H}+\mathrm{J}+\mathrm{K})$ & $\begin{array}{c}-0.361 * * * \\
(0.020)\end{array}$ & $\begin{array}{c}-0.175^{* * *} \\
(0.017)\end{array}$ & $\begin{array}{c}-0.247 * * * \\
(0.030)\end{array}$ & $\begin{array}{c}-0.220^{* * * *} \\
(0.037)\end{array}$ & $\begin{array}{c}-0.193^{* * *} \\
(0.015)\end{array}$ & $\begin{array}{c}-0.175 * * * \\
(0.025)\end{array}$ & $\begin{array}{c}-0.484 * * * \\
(0.032)\end{array}$ & $\begin{array}{c}-0.248^{* * * *} \\
(0.028)\end{array}$ & $\begin{array}{c}-0.921 * * * \\
(0.072)\end{array}$ & $\begin{array}{c}-0.349 * * * * \\
(0.020)\end{array}$ & $\begin{array}{c}-0.222^{* * *} \\
(0.010)\end{array}$ & $\begin{array}{c}-0.392^{* * *} \\
(0.010)\end{array}$ \\
\hline & Transportation (I) & $\begin{array}{c}-0.094 * * * \\
(0.016)\end{array}$ & $\begin{array}{c}-0.044 * * * \\
(0.010)\end{array}$ & $\begin{array}{c}-0.075^{* * * *} \\
(0.020)\end{array}$ & $\begin{array}{c}-0.053^{* * *} * \\
(0.012)\end{array}$ & $\begin{array}{c}-0.048^{* * * *} \\
(0.008)\end{array}$ & $\begin{array}{c}-0.035 * * * \\
(0.012)\end{array}$ & $\begin{array}{c}-0.444 * * * \\
(0.034)\end{array}$ & $\begin{array}{c}-0.218^{* * *} \\
(0.028)\end{array}$ & $\begin{array}{c}-0.910 * * * \\
(0.085)\end{array}$ & $\begin{array}{c}-0.156 * * * * \\
(0.012)\end{array}$ & $\begin{array}{c}-0.087 * * * \\
(0.008)\end{array}$ & $\begin{array}{c}-0.195 * * * \\
(0.015)\end{array}$ \\
\hline & Public administration and defense $(\mathrm{L})$ & $\begin{array}{c}0.401 * * * \\
(0.035) \\
\end{array}$ & $\begin{array}{c}0.160 * * * \\
(0.018) \\
\end{array}$ & $\begin{array}{c}0.265^{* * * *} \\
(0.038) \\
\end{array}$ & $\begin{array}{c}0.320^{* * * *} \\
(0.061)\end{array}$ & $\begin{array}{c}0.244^{* * *} \\
(0.030)\end{array}$ & $\begin{array}{c}0.239 * * * \\
(0.042) \\
\end{array}$ & $\begin{array}{c}0.220^{\text {**** }} \\
(0.032) \\
\end{array}$ & $\begin{array}{c}0.186^{* * *} \\
(0.037) \\
\end{array}$ & $\begin{array}{c}0.329 * * * \\
(0.055)\end{array}$ & $\begin{array}{c}0.278 * * * \\
(0.024)\end{array}$ & $\begin{array}{c}0.215^{* * *} \\
(0.017)\end{array}$ & $\begin{array}{c}0.250 * * * \\
(0.021)\end{array}$ \\
\hline \multicolumn{14}{|l|}{ Hourly wages } \\
\hline & Net hourly wages & $\begin{array}{c}0.000^{* * *} \\
(0.000)\end{array}$ & $\begin{array}{c}0.000^{* * *} \\
(0.000)\end{array}$ & $\begin{array}{c}0.000^{* * * *} \\
(0.000)\end{array}$ & $\begin{array}{c}0.000^{* * *} \\
(0.000)\end{array}$ & $\begin{array}{c}0.000^{* * *} \\
(0.000)\end{array}$ & $\begin{array}{c}0.000 * * * \\
(0.000)\end{array}$ & & & & $\begin{array}{c}0.015^{* * *} \\
(0.000)\end{array}$ & $\begin{array}{c}0.007 * * * \\
(0.002)\end{array}$ & $\begin{array}{c}0.027 * * * \\
(0.001)\end{array}$ \\
\hline Observations & & 48,734 & 23,752 & 24,982 & 70,431 & 34,274 & 36,157 & 19,629 & 9,199 & 10,430 & 44,989 & 21,499 & 23,490 \\
\hline
\end{tabular}

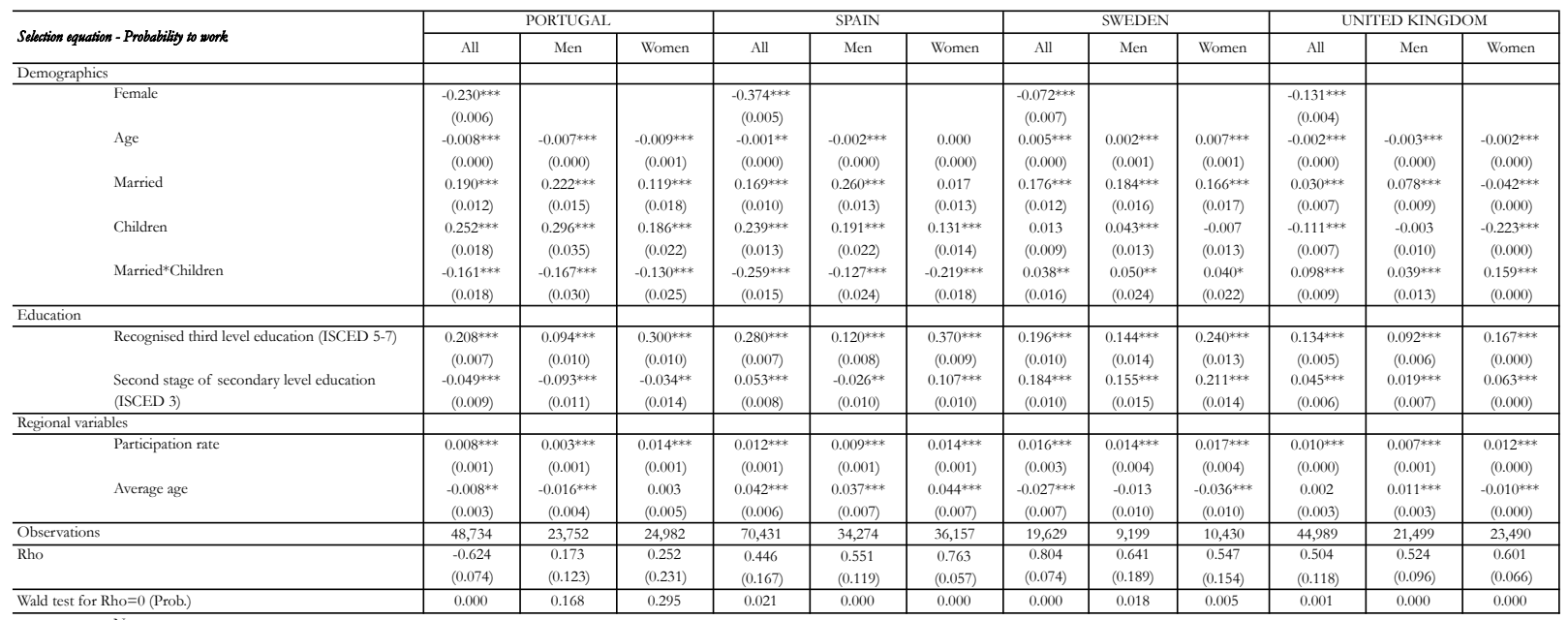

1. Robust weighted standard errors in parenthesis

1. Robust weighted standard errors in parenthesis

3. All estimations include year dummies not reported here 
Summing up, the wide variety of results discussed above allows us to draw the following general conclusions:

- All else equal, PS employment seems to be relatively more attractive for women vis-à-vis men in the Nordic countries, Germany, Ireland and Portugal, while it is less attractive in Italy, Spain and The Netherlands. No significant differences are observed in the remaining countries.

- In general, the PS attracts older women who are married and have children. This result would be consistent with Hypothesis (c).

- Regarding education, there is a significant group of countries (Italy, Spain, Sweden, and UK) where the PS attracts both higher educated men and women. In other countries, like Denmark and The Netherlands, there are important gender differences since the PS attracts more educated men, but not necessarily more educated women. Finally, in countries, such as Belgium, France and Portugal, the level of education does not seem to be a relevant determinant for the choice of PS vs. private sector.

- Regarding the degree of Femaleness (not reported) we do not find any statistically significant effect in all countries, providing therefore no support for Hypothesis (d).

Overall, except for Hypothesis (c), this evidence confirms that there is not a common rationalization explaining the choice of occupational sector across countries: we observe a wide variety of experiences that do not fit into a single theory.

\section{DIFFERENCES IN LABOR MARKET OUTCOMES - WAGE GAPS ACROSS SECTORS AND GENDER WAGE GAPS WITHIN EACH SECTOR}

As pointed out in the literature, gender differences in labor market outcomes (wages primarily) appear to be more muted in the PS than in the private sector. In line with this observation, our goal in this section is threefold:

a. To estimate wage gaps across sectors (for men and women separately).

b. To estimate gender wage gaps within PS and private sector jobs. 
c. To decompose average wage gaps across sectors (for men and women separately) so as to understand whether higher wages in the PS are primarily due to differences in characteristics or differences in rewards to given characteristics. ${ }^{7}$

\subsection{Wage gaps across sectors (for males and females separately) and gender wage gaps within public and private sector jobs}

Wage gaps between public and private sector jobs and between males and females are estimated using mincerian (logged) wage equations where all workers (in the PS and private sector and men and women together) are considered. After controlling for the standard determinants of wages, we include dummy variables for female and PS, and the interaction between these two dummy variables. The estimations of the coefficients on these three indicators yield the abovementioned adjusted wage gaps.

Detailed results on the OLS estimated hourly wage regressions by country are reported in Table 5 and the wage gaps calculated from the estimated coefficients are reported in Table 6.

\footnotetext{
${ }^{7}$ As will be explained below, we will not perform the Oaxaca-Blinder decomposition of average gender wage gaps within each sector because, for most countries, these gaps turn out to be negligible in the PS and therefore there is little to decompose.
} 
Table 5. OLS regressions to estimate wage gaps. Dependent variable: logged hourly gross wages

\begin{tabular}{|c|c|c|c|c|c|c|c|c|c|c|c|}
\hline & BELGIUM & DENMARK & FRANCE & GERMANY & GREECE & IRELAND & ITALY & NETHERLANDS & PORTUGAL & SPAIN & $\begin{array}{c}\text { UNITED } \\
\text { KINGDOM }\end{array}$ \\
\hline Female & $\begin{array}{c}-0.094^{* * *} \\
(0.032)\end{array}$ & $\begin{array}{c}0.028 \\
(0.046)\end{array}$ & $\begin{array}{c}-0.128 * * * \\
(0.026)\end{array}$ & $\begin{array}{c}-0.249 * * * \\
(0.039)\end{array}$ & $\begin{array}{c}-0.182^{* * *} \\
(0.033)\end{array}$ & $\begin{array}{c}-0.174 * * * \\
(0.037)\end{array}$ & $\begin{array}{c}-0.144 * * * \\
(0.021)\end{array}$ & $\begin{array}{c}-0.044^{*} \\
(0.025)\end{array}$ & $\begin{array}{c}-0.246^{* * *} \\
(0.030)\end{array}$ & $\begin{array}{c}-0.166^{* * *} \\
(0.039)\end{array}$ & $\begin{array}{c}-0.197 * * * \\
(0.040)\end{array}$ \\
\hline Public sector & $\begin{array}{l}-0.020 \\
(0.041)\end{array}$ & $\begin{array}{l}-0.068 \\
(0.065)\end{array}$ & $\begin{array}{c}0.174^{* * *} \\
(0.036)\end{array}$ & $\begin{array}{l}-0.092 \\
(0.076)\end{array}$ & $\begin{array}{c}0.143 * * * \\
(0.046)\end{array}$ & $\begin{array}{c}0.193^{* * *} \\
(0.049)\end{array}$ & $\begin{array}{c}0.025 \\
(0.032)\end{array}$ & $\begin{array}{l}0.053^{*} \\
(0.030)\end{array}$ & $\begin{array}{l}0.121^{*} \\
(0.061)\end{array}$ & $\begin{array}{l}0.101^{*} \\
(0.058)\end{array}$ & $\begin{array}{l}0.001 \\
(0.039)\end{array}$ \\
\hline Female*Public sector & $\begin{array}{c}0.076 \\
(0.047) \\
\end{array}$ & \begin{tabular}{|c|}
$-0.139^{*}$ \\
$(0.073)$ \\
\end{tabular} & $\begin{array}{l}-0.028 \\
(0.041) \\
\end{array}$ & $\begin{array}{c}0.173 * * * \\
(0.064) \\
\end{array}$ & $\begin{array}{c}0.126^{* * *} \\
(0.048) \\
\end{array}$ & $\begin{array}{c}0.066 \\
(0.051) \\
\end{array}$ & $\begin{array}{c}0.127 * * * \\
(0.037)\end{array}$ & $\begin{array}{c}0.000 \\
(0.039) \\
\end{array}$ & $\begin{array}{c}0.181^{* * *} \\
(0.065) \\
\end{array}$ & $\begin{array}{r}0.088 \\
(0.055) \\
\end{array}$ & $\begin{array}{l}0.089^{*} \\
(0.049) \\
\end{array}$ \\
\hline Demographics & & & & & & & & & & & \\
\hline $\begin{array}{l}\text { Age } \\
\text { Age squared } \\
\text { Married } \\
\text { Children }\end{array}$ & $\begin{array}{c}0.038^{* *} \\
(0.017) \\
-0.000 * * \\
(0.000) \\
-0.030 \\
(0.028) \\
0.056^{* *} \\
(0.026) \\
\end{array}$ & $\begin{array}{c}0.001 \\
(0.019) \\
0.000 \\
(0.000) \\
0.014 \\
(0.036) \\
0.039 \\
(0.037) \\
\end{array}$ & $\begin{array}{c}0.016 \\
(0.010) \\
-0.000 \\
(0.000) \\
0.021 \\
(0.021) \\
0.077^{* * *} \\
(0.023) \\
\end{array}$ & $\begin{array}{c}0.024^{* *} \\
(0.011) \\
-0.000^{* *} \\
(0.000) \\
0.024 \\
(0.029) \\
-0.014 \\
(0.031) \\
\end{array}$ & $\begin{array}{c}0.007 \\
(0.014) \\
-0.000 \\
(0.000) \\
0.046 \\
(0.034) \\
0.088 * * \\
(0.035) \\
\end{array}$ & $\begin{array}{c}0.018 \\
(0.013) \\
-0.000 \\
(0.000) \\
0.108^{* * *} \\
(0.035) \\
0.063^{*} \\
(0.035) \\
\end{array}$ & $\begin{array}{c}0.026^{* * *} \\
(0.008) \\
-0.000 * * * \\
(0.000) \\
0.063^{* * *} \\
(0.022) \\
0.005 \\
(0.022) \\
\end{array}$ & $\begin{array}{c}0.020^{*} \\
(0.012) \\
-0.000 \\
(0.000) \\
0.051^{*} * \\
(0.023) \\
0.036 \\
(0.022) \\
\end{array}$ & $\begin{array}{c}0.035^{* * *} \\
(0.010) \\
-0.000^{* * *} \\
(0.000) \\
0.082^{* * *} \\
(0.030) \\
-0.005 \\
(0.037) \\
\end{array}$ & $\begin{array}{c}0.037 * * * \\
(0.014) \\
-0.000 * * \\
(0.000) \\
0.026 \\
(0.031) \\
-0.007 \\
(0.035) \\
\end{array}$ & $\begin{array}{c}0.046^{* * *} \\
(0.011) \\
-0.001 * * * \\
(0.000) \\
0.047^{*} \\
(0.028) \\
0.043 \\
(0.027) \\
\end{array}$ \\
\hline \begin{tabular}{l|l} 
Education \\
\end{tabular} & & & & & & & & & & & \\
\hline 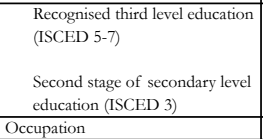 & $\begin{array}{c}0.233^{* * *} \\
(0.037) \\
0.100 * * * \\
(0.031) \\
\end{array}$ & $\begin{array}{c}0.217^{* * *} \\
(0.065) \\
0.147^{* *} \\
(0.062) \\
\end{array}$ & $\begin{array}{c}0.284^{* * *} \\
(0.032) \\
0.077^{* * *} \\
(0.022) \\
\end{array}$ & $\begin{array}{l}0.043 \\
(0.047) \\
-0.028 \\
(0.028) \\
\end{array}$ & $\begin{array}{c}0.225 * * * \\
(0.039) \\
0.102 * * * \\
(0.030) \\
\end{array}$ & $\begin{array}{c}0.269 * * * \\
(0.049) \\
0.134 * * * \\
(0.033) \\
\end{array}$ & $\begin{array}{c}0.278^{* * * *} \\
(0.037) \\
0.063^{* * * *} \\
(0.019) \\
\end{array}$ & $\begin{array}{c}0.208 * * * \\
(0.026) \\
0.075 * * * \\
(0.020) \\
\end{array}$ & $\begin{array}{c}0.500^{* * *} \\
(0.082) \\
0.148 * * * \\
(0.053) \\
\end{array}$ & $\begin{array}{c}0.228 * * * \\
(0.038) \\
0.081^{* *} \\
(0.032) \\
\end{array}$ & $\begin{array}{c}0.167 * * * \\
(0.030) \\
0.082^{* *} \\
(0.039) \\
\end{array}$ \\
\hline Professionals & $\begin{array}{c}-0.119^{*} \\
(0.067)\end{array}$ & $\begin{array}{l}-0.074 \\
(0.090)\end{array}$ & $\begin{array}{l}-0.086 \\
(0.065)\end{array}$ & $\begin{array}{l}-0.026 \\
(0.083)\end{array}$ & $\begin{array}{c}0.172 \\
(0.113)\end{array}$ & $\begin{array}{c}0.183^{* * *} \\
(0.068)\end{array}$ & $\begin{array}{l}-0.274 * * * \\
(0.101)\end{array}$ & $\begin{array}{l}0.060^{*} \\
(0.035)\end{array}$ & $\begin{array}{l}0.258^{*} \\
(0.147)\end{array}$ & $\begin{array}{c}-0.180^{*} \\
(0.103)\end{array}$ & $\begin{array}{l}0.045 \\
(0.046)\end{array}$ \\
\hline $\begin{array}{l}\text { Technicians and associate } \\
\text { professionals }\end{array}$ & $-0.249 * * *$ & -0.132 & $-0.325 * * *$ & $-0.261 * * *$ & -0.149 & 0.015 & $-0.323 * * *$ & 0.001 & 0.041 & $-0.417 * * *$ & $-0.085 *$ \\
\hline Clerks & $\begin{array}{c}(0.056) \\
-0.275^{* * *} \\
(0.056)\end{array}$ & $\begin{array}{c}(0.092) \\
-0.366^{* * *} \\
(0.102)\end{array}$ & $\begin{array}{c}(0.060) \\
-0.494 * * \\
(0.062)\end{array}$ & $\begin{array}{c}(0.078) \\
-0.300^{* * * *} \\
(0.092)\end{array}$ & $\begin{array}{c}(0.118) \\
-0.141 \\
(0.110)\end{array}$ & $\begin{array}{c}(0.068) \\
-0.147 * * \\
(0.066)\end{array}$ & $\begin{array}{c}(0.100) \\
-0.390^{* * * *} \\
(0.099)\end{array}$ & $\begin{array}{c}(0.036) \\
-0.107 * * * \\
(0.036)\end{array}$ & $\begin{array}{c}(0.162) \\
-0.194 \\
(0.162)\end{array}$ & $\begin{array}{c}(0.101) \\
-0.560 * * * \\
(0.101)\end{array}$ & $\begin{array}{c}(0.044) \\
-0.313^{* * *} \\
(0.052)\end{array}$ \\
\hline $\begin{array}{l}\text { Service workers and shop and } \\
\text { market sales workers }\end{array}$ & $\begin{array}{l}-0.395 * * * \\
(0.059)\end{array}$ & $\begin{array}{l}-0.243^{* *} \\
(0.102)\end{array}$ & $\begin{array}{l}-0.597 * * * \\
(0.067)\end{array}$ & $\begin{array}{c}-0.502 * * * \\
(0.087)\end{array}$ & $\begin{array}{l}-0.206^{*} \\
(0.117)\end{array}$ & $\begin{array}{c}-0.312 * * * \\
(0.067)\end{array}$ & $\begin{array}{c}-0.491 * * * \\
(0.102)\end{array}$ & $\begin{array}{c}-0.179 * * * \\
(0.043)\end{array}$ & $\begin{array}{l}-0.485 * * * \\
(0.165)\end{array}$ & $\begin{array}{c}-0.693 * * * \\
(0.102)\end{array}$ & $\begin{array}{c}-0.440 * * * \\
(0.050)\end{array}$ \\
\hline $\begin{array}{l}\text { Craft and related trade workers } \\
+ \text { skilled workers }\end{array}$ & $\begin{array}{l}-0.362^{* * *} \\
(0.063)\end{array}$ & $\begin{array}{l}-0.268^{* *} \\
(0.107)\end{array}$ & $\begin{array}{l}-0.580^{* * *} \\
(0.065)\end{array}$ & $\begin{array}{l}-0.521 * * * \\
(0.082)\end{array}$ & $\begin{array}{c}-0.313 * * * \\
(0.115)\end{array}$ & $\begin{array}{c}-0.219 * * * \\
(0.073)\end{array}$ & $\begin{array}{c}-0.503 * * * \\
(0.100)\end{array}$ & $\begin{array}{c}-0.188 * * * \\
(0.036)\end{array}$ & $\begin{array}{c}-0.478 * * * \\
(0.156)\end{array}$ & $\begin{array}{l}-0.646 * * * \\
(0.097)\end{array}$ & $\begin{array}{c}-0.356^{* * * *} \\
(0.047)\end{array}$ \\
\hline $\begin{array}{l}\text { Plant and machine operators } \\
\text { and assemblers }\end{array}$ & $-0.389 * * *$ & $-0.312^{* *}$ & $-0.567 * * *$ & $-0.489 * * *$ & $-0.213^{*}$ & $-0.305 * *$ & $-0.451^{* * *}$ & $-0.181 * * *$ & $-0.425 * * *$ & $-0.721 * * *$ & $-0.470^{* * *}$ \\
\hline Elementary occupations & $\begin{array}{c}(0.064) \\
-0.398 * * * \\
(0.066)\end{array}$ & $\begin{array}{c}(0.129) \\
-0.287^{* * *} \\
(0.103)\end{array}$ & $\begin{array}{c}(0.065) \\
-0.678 * * \\
(0.067)\end{array}$ & $\begin{array}{c}(0.086) \\
-0.580 * * * \\
(0.082)\end{array}$ & $\begin{array}{c}(0.114) \\
-0.303 * * * \\
(0.112)\end{array}$ & $\begin{array}{c}(0.070) \\
-0.500 * * * \\
(0.085)\end{array}$ & $\begin{array}{c}(0.101) \\
-0.534 * * * \\
(0.102)\end{array}$ & $\begin{array}{c}(0.048) \\
-0.284 * * * \\
(0.050)\end{array}$ & $\begin{array}{c}(0.158) \\
-0.545 * * * \\
(0.162)\end{array}$ & $\begin{array}{c}(0.103) \\
-0.736^{* * *} \\
(0.103)\end{array}$ & $\begin{array}{c}(0.051) \\
-0.608^{* * *} \\
(0.060)\end{array}$ \\
\hline Sector of activity & & & & & & & & & & & \\
\hline Industry $(\mathrm{E}+\mathrm{D}+\mathrm{F})$ & $\begin{array}{l}0.080 * * \\
(0.032)\end{array}$ & $\begin{array}{c}0.031 \\
(0.061)\end{array}$ & $\begin{array}{c}0.119 * * * \\
(0.035)\end{array}$ & $\begin{array}{c}0.081 \\
(0.055)\end{array}$ & $\begin{array}{l}0.087^{*} \\
(0.049)\end{array}$ & $\begin{array}{l}0.088^{*} \\
(0.051)\end{array}$ & $\begin{array}{l}0.060 * * \\
(0.027)\end{array}$ & $\begin{array}{l}0.047^{*} \\
(0.027)\end{array}$ & $\begin{array}{l}0.100^{* *} \\
(0.048)\end{array}$ & $\begin{array}{c}0.075 \\
(0.052)\end{array}$ & $\begin{array}{c}0.158^{* * *} \\
(0.042)\end{array}$ \\
\hline Other services $(\mathrm{G}+\mathrm{H}+\mathrm{J}+\mathrm{K})$ & $\begin{array}{l}0.031 \\
(0.041)\end{array}$ & $\begin{array}{l}-0.033 \\
(0.063)\end{array}$ & $\begin{array}{c}0.093 * * * \\
(0.032)\end{array}$ & $\begin{array}{r}-0.065 \\
(0.048)\end{array}$ & $\begin{array}{r}-0.019 \\
(0.043)\end{array}$ & $\begin{array}{l}-0.032 \\
(0.048)\end{array}$ & $\begin{array}{l}0.028 \\
(0.030)\end{array}$ & $\begin{array}{c}0.038 \\
(0.024)\end{array}$ & $\begin{array}{c}0.140^{* * *} \\
(0.048)\end{array}$ & $\begin{array}{l}-0.026 \\
(0.054)\end{array}$ & $\begin{array}{c}0.092^{* *} \\
(0.042)\end{array}$ \\
\hline Transportation (I) & $\begin{array}{l}0.033 \\
(0.056)\end{array}$ & $\begin{array}{l}0.043 \\
(0.084)\end{array}$ & $\begin{array}{l}0.056 \\
(0.046)\end{array}$ & $\begin{array}{l}-0.034 \\
(0.084)\end{array}$ & $\begin{array}{l}0.040 \\
(0.070)\end{array}$ & $\begin{array}{l}-0.078 \\
(0.057)\end{array}$ & $\begin{array}{l}0.016 \\
(0.038)\end{array}$ & $\begin{array}{l}0.062^{*} \\
(0.035)\end{array}$ & $\begin{array}{l}0.102 \\
(0.085)\end{array}$ & $\begin{array}{l}0.015 \\
(0.066)\end{array}$ & $\begin{array}{l}0.084 \\
(0.052)\end{array}$ \\
\hline $\begin{array}{l}\text { Public administration and } \\
\text { defense (L) }\end{array}$ & $\begin{array}{c}0.044 \\
(0.046)\end{array}$ & $\begin{array}{l}0.161 * * \\
(0.062)\end{array}$ & $\begin{array}{c}0.017 \\
(0.037)\end{array}$ & $\begin{array}{l}-0.026 \\
(0.040)\end{array}$ & $\begin{array}{l}-0.055 \\
(0.041)\end{array}$ & $\begin{array}{l}-0.011 \\
(0.050)\end{array}$ & $\begin{array}{c}0.028 \\
(0.030)\end{array}$ & $\begin{array}{c}0.102 * * * \\
(0.034)\end{array}$ & $\begin{array}{l}0.013 \\
(0.055)\end{array}$ & $\begin{array}{l}-0.014 \\
(0.046)\end{array}$ & $\begin{array}{c}0.264 * * * \\
(0.040)\end{array}$ \\
\hline Other job characteristics & & & & & & & & & & & \\
\hline Tenure & $\begin{array}{l}0.015 \\
(0.009)\end{array}$ & $\begin{array}{c}0.030 \\
(0.020)\end{array}$ & $\begin{array}{c}0.028^{* * *} \\
(0.008)\end{array}$ & $\begin{array}{l}0.027 * * \\
(0.011)\end{array}$ & $\begin{array}{l}0.020^{*} \\
(0.011)\end{array}$ & $\begin{array}{c}0.011 \\
(0.011)\end{array}$ & $\begin{array}{l}0.014^{* *} \\
(0.007)\end{array}$ & $\begin{array}{c}0.001 \\
(0.008)\end{array}$ & $\begin{array}{l}-0.010 \\
(0.012)\end{array}$ & $\begin{array}{c}0.017 \\
(0.011)\end{array}$ & $\begin{array}{c}0.006 \\
(0.010)\end{array}$ \\
\hline Tenure squared & $\begin{array}{l}-0.000 \\
(0.001)\end{array}$ & $\begin{array}{l}-0.001 \\
(0.002)\end{array}$ & $\begin{array}{c}-0.001 * * \\
(0.001)\end{array}$ & $\begin{array}{c}-0.001 \\
(0.001)\end{array}$ & $\begin{array}{l}-0.000 \\
(0.001)\end{array}$ & $\begin{array}{l}0.000 \\
(0.001)\end{array}$ & $\begin{array}{l}-0.000 \\
(0.001)\end{array}$ & $\begin{array}{c}0.001 \\
(0.001)\end{array}$ & $\begin{array}{c}0.001 \\
(0.001)\end{array}$ & $\begin{array}{l}-0.001 \\
(0.001)\end{array}$ & $\begin{array}{l}-0.000 \\
(0.001)\end{array}$ \\
\hline Full time contract & $\begin{array}{l}-0.002 \\
(0.034)\end{array}$ & $\begin{array}{l}0.029 \\
(0.085)\end{array}$ & $\begin{array}{l}-0.051 \\
(0.035)\end{array}$ & $\begin{array}{l}-0.049 \\
(0.051)\end{array}$ & $\begin{array}{l}-0.036 \\
(0.092)\end{array}$ & $\begin{array}{l}0.119 * * \\
(0.050)\end{array}$ & $\begin{array}{c}-0.198 * * * \\
(0.040)\end{array}$ & $\begin{array}{c}0.113 * * * \\
(0.030)\end{array}$ & $\begin{array}{c}0.105 \\
(0.114)\end{array}$ & $\begin{array}{l}-0.058 \\
(0.046)\end{array}$ & $\begin{array}{l}0.000 \\
(0.000)\end{array}$ \\
\hline Permanent contract & $\begin{array}{l}0.108^{* *} \\
(0.042)\end{array}$ & $\begin{array}{l}-0.173 \\
(0.152)\end{array}$ & $\begin{array}{c}0.052 \\
(0.050)\end{array}$ & $\begin{array}{c}0.074 \\
(0.089)\end{array}$ & $\begin{array}{c}0.031 \\
(0.041)\end{array}$ & $\begin{array}{l}0.159^{* *} \\
(0.063)\end{array}$ & $\begin{array}{c}0.121^{* * * *} \\
(0.042)\end{array}$ & $\begin{array}{c}0.355^{* * * *} \\
(0.116)\end{array}$ & $\begin{array}{c}0.119 * * * \\
(0.046)\end{array}$ & $\begin{array}{c}0.239 * * * \\
(0.036)\end{array}$ & $\begin{array}{l}0.296^{*} \\
(0.159)\end{array}$ \\
\hline Constant & $\begin{array}{l}4.879 * * * \\
(0.317)\end{array}$ & $\begin{array}{l}4.497 * * * \\
(0.379)\end{array}$ & $\begin{array}{l}3.510^{* * * *} \\
(0.206)\end{array}$ & $\begin{array}{c}2.609 * * * * \\
(0.290)\end{array}$ & $\begin{array}{c}6.669 * * * \\
(0.290)\end{array}$ & $\begin{array}{c}0.850 * * * \\
(0.260)\end{array}$ & $\begin{array}{c}2.106 * * * \\
(0.191)\end{array}$ & $\begin{array}{c}1.916 * * * \\
(0.213)\end{array}$ & $\begin{array}{c}5.335 * * * \\
(0.261)\end{array}$ & $\begin{array}{c}6.022 * * * \\
(0.280)\end{array}$ & $\begin{array}{c}0.413 \\
(0.260)\end{array}$ \\
\hline Observations & 869 & 192 & 1,945 & 2,307 & 912 & 831 & 1,640 & 1,924 & 1,572 & 1,351 & 1,212 \\
\hline R-squared & 0.349 & 0.453 & 0.415 & 0.302 & 0.501 & 0.535 & 0.405 & 0.319 & 0.646 & 0.532 & 0.408 \\
\hline
\end{tabular}

Table 6. Estimated wage gaps from regressions estimated in Table 5

\begin{tabular}{|c|c|c|c|c|c|c|c|c|c|c|c|c|}
\hline & & BELGIUM & DENMARK & FRANCE & GERMANY & GREECE & IRELAND & ITALY & NETHERLANDS & PORTUGAL & SPAIN & $\begin{array}{c}\text { UNITED } \\
\text { KINGDOM }\end{array}$ \\
\hline \multirow{2}{*}{$\begin{array}{l}\text { Gender wage gap } \\
\text { (difference between } \\
\text { women and me) }\end{array}$} & $\begin{array}{l}\text { Sector público (coeff. Female+coeff. } \\
\text { Female*Public sector) }\end{array}$ & $\begin{array}{r}-1.80 \% \\
(0.68)\end{array}$ & $\begin{array}{c}-11.10 \% \\
(0.09)\end{array}$ & $\begin{array}{c}-15.60 \% \\
(0.00)\end{array}$ & $\begin{array}{r}-7.60 \% \\
(0.09)\end{array}$ & $\begin{array}{r}-5.60 \% \\
(0.14)\end{array}$ & $\begin{array}{c}-10.80 \% \\
(0.01)\end{array}$ & $\begin{array}{r}-1.70 \% \\
(0.59)\end{array}$ & $\begin{array}{c}-4.40 \% \\
(0.26)\end{array}$ & $\begin{array}{l}-6.50 \% \\
(0.30)\end{array}$ & $\begin{array}{c}-7.80 \% \\
(0.05)\end{array}$ & $\begin{array}{c}-10.80 \% \\
(0.00)\end{array}$ \\
\hline & Sector privado (coeff. Female) & $\begin{array}{c}-9.40 \% \\
(0.00)\end{array}$ & $\begin{array}{r}2.80 \% \\
(0.54)\end{array}$ & $\begin{array}{c}-12.80 \% \\
(0.00)\end{array}$ & $\begin{array}{c}-24.90 \% \\
(0.00)\end{array}$ & $\begin{array}{c}-18.20 \% \\
(0.00)\end{array}$ & $\begin{array}{c}-17.40 \% \\
(0.00)\end{array}$ & $\begin{array}{c}-14.40 \% \\
(0.00)\end{array}$ & $\begin{array}{c}-4.40 \% \\
(0.07) \\
\end{array}$ & $\begin{array}{c}-24.60 \% \\
(0.00)\end{array}$ & $\begin{array}{c}-16.60 \% \\
(0.00)\end{array}$ & $\begin{array}{c}-19.70 \% \\
(0.00)\end{array}$ \\
\hline \multirow{2}{*}{$\begin{array}{l}\text { Sector wage gap } \\
\text { (difference between } \\
\text { Public sector and } \\
\text { Private sector) }\end{array}$} & $\begin{array}{l}\text { Females (coeff. Public sector+coeff. } \\
\text { Female*Public sector) }\end{array}$ & $\begin{array}{l}5.60 \% \\
(0.09)\end{array}$ & $\begin{array}{c}-20.70 \% \\
(0.00)\end{array}$ & $\begin{array}{c}14.60 \% \\
(0.00)\end{array}$ & $\begin{array}{r}8.10 \% \\
(0.10)\end{array}$ & $\begin{array}{c}26.90 \% \\
(0.00)\end{array}$ & $\begin{array}{c}25.90 \% \\
(0.00) \\
\end{array}$ & $\begin{array}{c}15.20 \% \\
(0.00)\end{array}$ & $\begin{array}{l}5.30 \% \\
(0.13)\end{array}$ & $\begin{array}{c}30.20 \% \\
(0.00)\end{array}$ & $\begin{array}{c}18.90 \% \\
(0.00)\end{array}$ & $\begin{array}{l}9.00 \% \\
(0.03)\end{array}$ \\
\hline & Males (coeff. Public sector) & $\begin{array}{c}-2.00 \% \\
(0.62)\end{array}$ & $\begin{array}{c}-6.80 \% \\
(0.29)\end{array}$ & $\begin{array}{c}17.40 \% \\
(0.00)\end{array}$ & $\begin{array}{c}-9.20 \% \\
(0.22)\end{array}$ & $\begin{array}{c}14.30 \% \\
(0.00)\end{array}$ & $\begin{array}{c}19.30 \% \\
(0.00)\end{array}$ & $\begin{array}{r}2.50 \% \\
(0.42)\end{array}$ & $\begin{array}{l}5.30 \% \\
(0.07)\end{array}$ & $\begin{array}{c}12.10 \% \\
(0.05)\end{array}$ & $\begin{array}{c}10.10 \% \\
(0.08)\end{array}$ & $\begin{array}{r}0.10 \% \\
(0.96)\end{array}$ \\
\hline
\end{tabular}


The main findings can be summarized as follows.

\section{1) Sector wage gaps (difference between $P S$ wages and private sector wages) for women and men.}

As regards women, wages in the PS are either higher or not significantly different from those in the private sector, once other observables are controlled for. The only exception is Denmark, where women in the PS earn $20 \%$ less on average than in the private sector. The gap for women in favor of the PS is higher in Greece, Ireland and Portugal, (above 25\%), somewhat smaller in France, Italy and Spain (between 15\% and 20\%), and even smaller in the UK (10\%). Hence, in line with Hypothesis (b), this evidence points out that women who work in the PS do better in terms of wages than those with similar characteristics who choose to work in the private sector.

With regard to men, wages in the PS turn out to be less advantageous than for women. Indeed, in most countries, wage gaps of similar men working in the two sectors are not significantly different from zero at $5 \%$ level. We only find a statistically significant wage gap in favor of the PS in France (17\%), Greece (14\%) and Ireland (19\%).

\section{2) Gender wage gaps within each sector.}

For most countries (Belgium, Germany, Greece, Ireland, Italy, Portugal, Spain and $\mathrm{UK})$, gender wage gaps are much larger in the private sector than in the PS, ranging from $8 \%$ to $25 \%$. Indeed, looking at average gender wage gaps in the PS, they can be considered as negligible in all countries, but France, The Netherlands and UK. In line with Hypotheses (b) and (c), this may be one important reason for women concentrating in PS jobs in most countries.

For countries such as France and The Netherlands, gender wage gaps in the PS and private sector are fairly similar besides being in general quite small in magnitude. Interestingly, in Denmark the gender wage gap in the PS is much higher than in the private sector, in line with the evidence by Albrecht et al. (2003) about the existence of strong glass ceiling pattern in the public administration of Sweden, another Nordic country. 


\subsection{Decomposition of wage gaps in differences of characteristics and rewards}

\subsubsection{Decomposing wage gaps across sectors ${ }^{8}-$ Results}

We compute the Blinder-Oaxaca decomposition for average wage differentials between the PS and the private sector, separately for women and men. Table 7 contains the main results of the decomposition. We aggregate the observable characteristics that will contribute to the wage differential into three groups: human capital (age, level of education and tenure), family characteristics (civil status and having children or not) and job characteristics (occupation, industry, part-time/full-time job and indefinite/temporary contract). Table A1 in the Appendix displays the results of the decomposition separately for each of the above-mentioned characteristics in these three groups. Finally, Table A2 in the Appendix presents the results of the OLS estimations underlying the Oaxaca-Blinder decomposition.

\footnotetext{
${ }^{8}$ As mentioned before, we do not present Oaxaca-Blinder decompositions of the gender wage gap within sectors, given that average gender wage gap (presented above) in the PS is almost negligible in most countries.
} 
Table 7. Oaxaca-Blinder Wage Decomposition (Logged Gross Hourly Wages)

\begin{tabular}{|c|c|c|c|c|c|c|c|c|}
\hline & \multicolumn{4}{|c|}{ Belgium } & \multicolumn{4}{|c|}{ Denmark } \\
\hline & \multicolumn{2}{|c|}{ Females } & \multicolumn{2}{|c|}{ Males } & \multicolumn{2}{|c|}{ Females } & \multicolumn{2}{|c|}{ Males } \\
\hline & \multicolumn{2}{|c|}{$\begin{array}{l}\text { Log wage gap between public and } \\
\text { private sectors }=0.1134\end{array}$} & \multicolumn{2}{|c|}{$\begin{array}{c}\text { Log wage gap between public and } \\
\text { private sectors }=0.0680\end{array}$} & \multicolumn{2}{|c|}{$\begin{array}{c}\text { Log wage gap between public and } \\
\text { private sectors }=-0.1050\end{array}$} & \multicolumn{2}{|c|}{$\begin{array}{l}\text { Log wage gap between public and } \\
\text { private sectors }=-0.0265\end{array}$} \\
\hline Variables & $\begin{array}{c}\text { Explained part (gap } \\
\text { in endowments) }\end{array}$ & Unexplained part & \begin{tabular}{|l|} 
Explained part (gap \\
in endowments)
\end{tabular} & Unexplained part & \begin{tabular}{|c|} 
Explained part (gap \\
in endowments)
\end{tabular} & Unexplained part & \begin{tabular}{|l|} 
Explained part (gap \\
in endowments)
\end{tabular} & Unexplained part \\
\hline \multirow{2}{*}{$\begin{array}{l}\text { Human capital (age, education } \\
\text { and tenure) }\end{array}$} & \begin{tabular}{|l|}
0.0339 \\
\end{tabular} & -1.0381 & $\begin{array}{l}0.0547 \\
\end{array}$ & 0.2129 & -0.0086 & -1.5177 & 0.0102 & -3.8925 \\
\hline & $29.88 \%$ & $-914.91 \%$ & $80.29 \%$ & $312.77 \%$ & $8.22 \%$ & $1444.44 \%$ & $-38.35 \%$ & $14665.04 \%$ \\
\hline \multirow{2}{*}{$\begin{array}{l}\text { Family charact. (married, } \\
\text { children) }\end{array}$} & 0.0027 & 0.0185 & -0.0046 & -0.0026 & -0.0129 & -0.0118 & -0.0077 & -0.0012 \\
\hline & $2.38 \%$ & $16.31 \%$ & $-6.72 \%$ & $-3.76 \%$ & $12.23 \%$ & $11.21 \%$ & $28.95 \%$ & $4.67 \%$ \\
\hline \multirow{4}{*}{$\begin{array}{l}\text { Job characteristics } \\
\text { (occupation, idustry, part- } \\
\text { time/full-time, type of contract) } \\
\text { Constant }\end{array}$} & 0.0536 & 0.1170 & 0.0201 & -0.5265 & 0.0076 & 0.1229 & -0.0223 & -0.1489 \\
\hline & $47.25 \%$ & $103.12 \%$ & $29.60 \%$ & $-773.39 \%$ & $-7.19 \%$ & $-116.93 \%$ & $84.00 \%$ & $561.00 \%$ \\
\hline & 0.0000 & 0.9258 & 0.0000 & 0.3140 & 0.0000 & 1.3155 & 0.0000 & 4.0359 \\
\hline & $0.00 \%$ & $815.96 \%$ & $0.00 \%$ & $461.21 \%$ & $0.00 \%$ & $-1251.98 \%$ & $0.00 \%$ & $-15205.30 \%$ \\
\hline \multirow[t]{2}{*}{ Total } & 0.0902 & 0.0232 & 0.0702 & -0.0022 & -0.0139 & -0.0911 & -0.0198 & -0.0067 \\
\hline & $79.52 \%$ & $20.48 \%$ & $103.17 \%$ & $-3.17 \%$ & $13.27 \%$ & $86.73 \%$ & $74.59 \%$ & $25.41 \%$ \\
\hline No. of observations & 419 & & 463 & & 89 & & 103 & \\
\hline
\end{tabular}

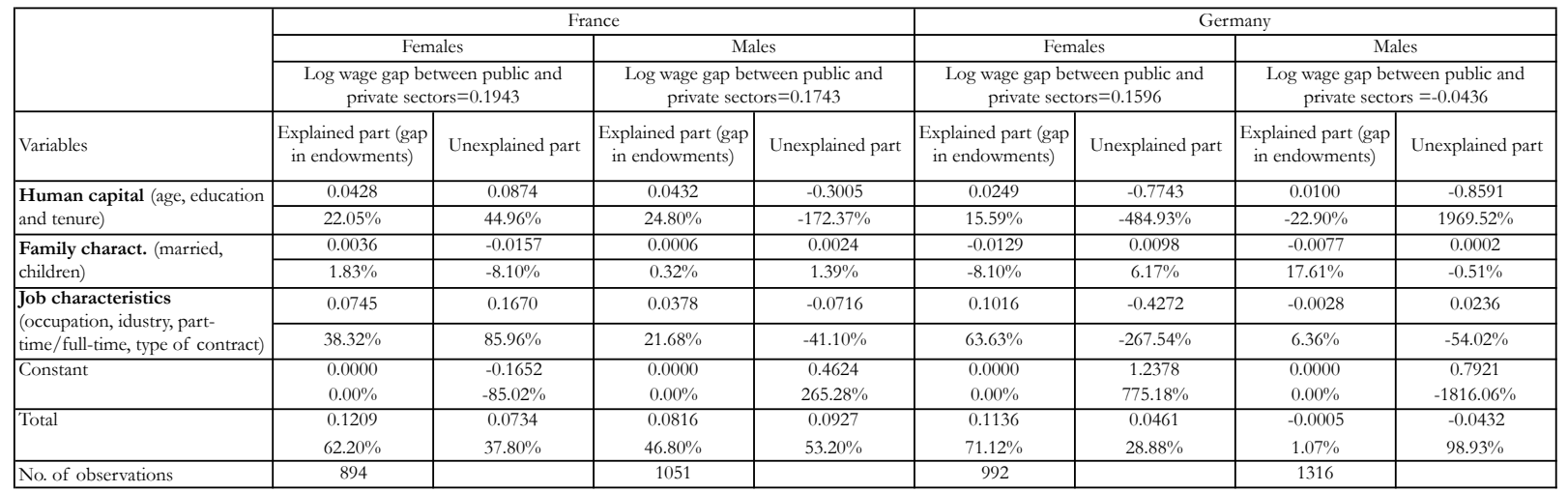

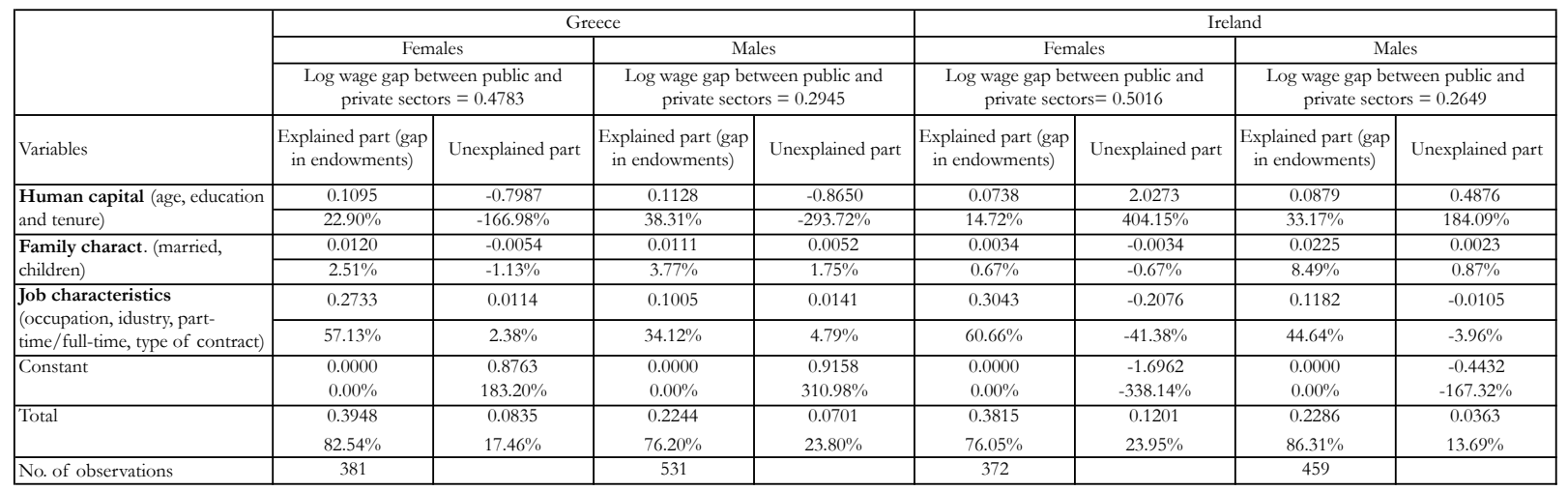

\begin{tabular}{|c|c|c|c|c|c|c|c|c|}
\hline \multirow[b]{4}{*}{ Variables } & \multicolumn{4}{|c|}{ Italy } & \multicolumn{4}{|c|}{ Netherlands } \\
\hline & \multicolumn{2}{|c|}{ Females } & \multicolumn{2}{|c|}{ Males } & \multicolumn{2}{|c|}{ Females } & \multicolumn{2}{|c|}{ Males } \\
\hline & \multicolumn{2}{|c|}{$\begin{array}{c}\text { Log wage gap between public and } \\
\text { private sectors }=0.2991\end{array}$} & \multicolumn{2}{|c|}{$\begin{array}{c}\text { Log wage gap between public and } \\
\text { private sectors }=0.1429\end{array}$} & \multicolumn{2}{|c|}{$\begin{array}{c}\text { Log wage gap between public and } \\
\text { private sectors }=0.1368\end{array}$} & \multicolumn{2}{|c|}{$\begin{array}{c}\text { Log wage gap between public and } \\
\text { private sectors }=0.1980\end{array}$} \\
\hline & $\begin{array}{c}\text { Explained part (gap } \\
\text { in endowments) }\end{array}$ & Unexplained part & $\begin{array}{c}\text { Explained part (gap } \\
\text { in endowments) }\end{array}$ & Unexplained part & $\begin{array}{l}\text { Explained part (gap } \\
\text { in endowments) }\end{array}$ & Unexplained part & $\begin{array}{c}\text { Explained part (gap } \\
\text { in endowments) }\end{array}$ & Unexplained part \\
\hline \multirow{2}{*}{$\begin{array}{l}\text { Human capital (age, education } \\
\text { and tenure) }\end{array}$} & 0.0828 & -1.1541 & 0.1008 & -0.2271 & 0.0440 & -1.1488 & 0.0958 & -0.2537 \\
\hline & $27.69 \%$ & $-385.84 \%$ & $70.56 \%$ & $-158.94 \%$ & $32.15 \%$ & $-839.34 \%$ & $48.35 \%$ & $-128.08 \%$ \\
\hline \multirow{2}{*}{$\begin{array}{l}\text { Family charact. (married, } \\
\text { children) }\end{array}$} & 0.0044 & -0.0095 & 0.0178 & 0.0078 & 0.0012 & $\begin{array}{l}-0.0091 \\
\end{array}$ & 0.0035 & $\begin{array}{l}-0.0025 \\
\end{array}$ \\
\hline & $1.47 \%$ & $-3.17 \%$ & $12.48 \%$ & $5.43 \%$ & $0.87 \%$ & $-6.68 \%$ & $1.76 \%$ & $-1.27 \%$ \\
\hline \multirow{2}{*}{$\begin{array}{l}\text { Job characteristics } \\
\text { (occupation, idustry, part- } \\
\text { time/full-time, type of contract) }\end{array}$} & 0.1504 & -0.2239 & 0.0162 & -0.0936 & 0.0798 & -0.1358 & 0.0586 & -0.0616 \\
\hline & $50.27 \%$ & $-74.84 \%$ & $11.36 \%$ & $-65.52 \%$ & $58.28 \%$ & $-99.21 \%$ & $29.61 \%$ & $-31.09 \%$ \\
\hline \multirow[t]{2}{*}{ Constant } & 0.0000 & 1.4490 & 0.0000 & 0.3210 & 0.0000 & 1.3056 & 0.0000 & 0.3579 \\
\hline & $0.00 \%$ & $484.42 \%$ & $0.00 \%$ & $224.63 \%$ & $0.00 \%$ & $953.94 \%$ & $0.00 \%$ & $180.73 \%$ \\
\hline \multirow[t]{2}{*}{ Total } & 0.2376 & 0.0615 & 0.1349 & 0.0080 & 0.1250 & 0.0119 & 0.1579 & 0.0402 \\
\hline & $79.43 \%$ & $20.57 \%$ & $94.40 \%$ & $5.60 \%$ & $91.30 \%$ & $8.70 \%$ & $79.72 \%$ & $20.28 \%$ \\
\hline No. of observations & 708 & & 935 & & 829 & & 1101 & \\
\hline
\end{tabular}


Table 7 (cont.). Oaxaca-Blinder Wage Decomposition (Logged Gross hourly wages)

\begin{tabular}{|c|c|c|c|c|c|c|c|c|}
\hline & \multicolumn{4}{|c|}{ Portugal } & \multicolumn{4}{|c|}{ Spain } \\
\hline & \multicolumn{2}{|c|}{ Females } & \multicolumn{2}{|c|}{ Males } & \multicolumn{2}{|c|}{ Females } & \multicolumn{2}{|c|}{ Males } \\
\hline & \multicolumn{2}{|c|}{$\begin{array}{l}\text { Log wage gap between public and private } \\
\text { sectors }=0.6281\end{array}$} & \multicolumn{2}{|c|}{$\begin{array}{l}\text { Log wage gap between public and private } \\
\text { sectors }=0.3051\end{array}$} & \multicolumn{2}{|c|}{$\begin{array}{c}\text { Log wage gap between public and private } \\
\text { sectors }=0.5011\end{array}$} & \multicolumn{2}{|c|}{$\begin{array}{l}\text { Log wage gap between public and private } \\
\text { sectors }=0.2952\end{array}$} \\
\hline Variables & $\begin{array}{l}\text { Explained part (gap } \\
\text { in endowments) }\end{array}$ & Unexplained part & $\begin{array}{l}\text { Explained part (gap } \\
\text { in endowments) }\end{array}$ & Unexplained part & $\begin{array}{l}\text { Explained part (gap } \\
\text { in endowments) }\end{array}$ & Unexplained part & $\begin{array}{l}\text { Explained part (gap } \\
\text { in endowments) }\end{array}$ & Unexplained part \\
\hline \multirow{2}{*}{$\begin{array}{l}\text { Human capital (age, education } \\
\text { and tenure) }\end{array}$} & \begin{tabular}{|c|}
0.1700 \\
\end{tabular} & 1.1073 & 0.1551 & -0.3040 & 0.1741 & -0.1065 & 0.1003 & -1.3168 \\
\hline & $27.07 \%$ & $176.29 \%$ & $50.84 \%$ & $-99.65 \%$ & $34.74 \%$ & $-21.24 \%$ & $33.99 \%$ & $-446.11 \%$ \\
\hline \multirow{2}{*}{$\begin{array}{l}\text { Family charact. (married, } \\
\text { children) }\end{array}$} & 0.0028 & 0.0177 & 0.0163 & 0.0171 & 0.0178 & -0.0132 & 0.0009 & 0.0116 \\
\hline & $0.45 \%$ & $2.82 \%$ & $5.36 \%$ & $5.59 \%$ & $3.55 \%$ & $-2.63 \%$ & $0.30 \%$ & $3.92 \%$ \\
\hline \multirow{2}{*}{$\begin{array}{l}\text { Job characteristics (occupation, } \\
\text { idustry, part-time/ full-time, type of } \\
\text { contract) }\end{array}$} & 0.3376 & 0.3461 & 0.0956 & 0.1421 & 0.2512 & 0.1258 & 0.1422 & -0.1259 \\
\hline & $53.75 \%$ & $55.10 \%$ & $31.32 \%$ & $46.56 \%$ & $50.12 \%$ & $25.10 \%$ & $48.17 \%$ & $-42.65 \%$ \\
\hline Constant & $\begin{array}{l}0.0000 \\
0.00 \%\end{array}$ & $\begin{array}{l}-1.3534 \\
-215.48 \%\end{array}$ & $\begin{array}{l}0.0000 \\
0.00 \%\end{array}$ & $\begin{array}{l}0.1830 \\
59.97 \%\end{array}$ & $\begin{array}{l}0.0000 \\
0.00 \%\end{array}$ & $\begin{array}{c}0.0520 \\
10.37 \%\end{array}$ & $\begin{array}{l}0.0000 \\
0.00 \%\end{array}$ & $\begin{array}{c}1.4829 \\
502.38 \%\end{array}$ \\
\hline Total & $\begin{array}{l}0.5105 \\
81.27 \%\end{array}$ & $\begin{array}{l}0.1176 \\
18.73 \%\end{array}$ & $\begin{array}{l}0.2670 \\
87.53 \%\end{array}$ & $\begin{array}{c}0.0381 \\
12.47 \%\end{array}$ & $\begin{array}{r}0.4430 \\
88.41 \%\end{array}$ & $\begin{array}{c}0.0581 \\
11.59 \%\end{array}$ & $\begin{array}{c}0.2434 \\
82.46 \%\end{array}$ & $\begin{array}{c}0.0518 \\
17.54 \%\end{array}$ \\
\hline No. of observations & 699 & & 873 & & 534 & & 826 & \\
\hline
\end{tabular}

\begin{tabular}{|l|c|c|c|c|}
\hline \multirow{2}{*}{} & \multicolumn{3}{|c|}{ United Kingdom } \\
\cline { 2 - 5 } & \multicolumn{2}{|c|}{$\begin{array}{c}\text { Females } \\
\text { Log wage gap between public and private } \\
\text { sectors }\end{array}$} & $\begin{array}{c}\text { Log wage gap between public and private } \\
\text { sectors }=0.1058\end{array}$ \\
\hline \multirow{2}{*}{ Variables } & $\begin{array}{c}\text { Explained part (gap } \\
\text { in endowments) }\end{array}$ & Unexplained part & $\begin{array}{c}\text { Explained part (gap } \\
\text { in endowments) }\end{array}$ & Unexplained part \\
\hline Human capital (age, education and & 0.0451 & -0.0308 & 0.0593 & -0.5512 \\
\cline { 2 - 5 } tenure) & $20.76 \%$ & $-14.19 \%$ & $56.05 \%$ & $-520.78 \%$ \\
\hline \multirow{2}{*}{ Family charact. (married, children) } & -0.0036 & 0.0146 & -0.0081 & -0.0220 \\
\cline { 2 - 5 } & $-1.66 \%$ & $6.73 \%$ & $-7.63 \%$ & $-20.75 \%$ \\
\hline \multirow{2}{*}{$\begin{array}{l}\text { Job characteristics (occupation, } \\
\text { idustry, part-time/full-time, type of } \\
\text { contract) }\end{array}$} & 0.1578 & 0.0659 & 0.0274 & -0.0412 \\
\cline { 2 - 5 } & $72.67 \%$ & $30.33 \%$ & $25.84 \%$ & $-38.88 \%$ \\
\hline Constant & 0.0000 & -0.0318 & 0.0000 & 0.6416 \\
& $0.00 \%$ & $-14.65 \%$ & $0.00 \%$ & $606.15 \%$ \\
\hline Total & 0.1993 & 0.0179 & 0.0786 & 0.0272 \\
& $91.77 \%$ & $8.23 \%$ & $74.27 \%$ & $25.73 \%$ \\
\hline No. of observations & 513 & & 699 & \\
\hline
\end{tabular}

For each country, we report (separately for men and women) the estimated (average) logged hourly wage differential between the PS and the private sector. This wage differential is decomposed into differences in characteristics (first column) and differences in rewards (second column). The contribution of each characteristic, to both the explained and unexplained parts is reported in each of the columns both in absolute terms and in percentage terms. ${ }^{?}$

The most salient findings from these wage gap decompositions can be summarized as follows:

1. In general, the gap between the (average) wage in the PS and private sector is positive (i.e., wages are higher in the PS). Moreover, this gap is higher for women than for men in all countries but The Netherlands. Looking at the magnitude of the PS-private sector wage gap, we can identify a first group of countries (Greece, Ireland, Portugal and Spain) with rather high wage gaps in favor of the PS - between 45-62\% for women and between 20 $30 \%$ for men. Next, there is a second group of countries (Belgium, France, Italy, The

\footnotetext{
${ }^{9}$ Let us consider, for instance, the average wage differential in Belgium for females (0.113). The contribution of the level of education to this wage differential is the following: differences in the level of education between females in the PS vs. the private sector explain $0.0225(19.8 \%)$ of the observed wage differential (0.113). Differences in the returns to education in public versus private jobs have a negative sign $(-0.0214)$ which indicates that returns to education in the private sector are higher on average than in the PS for females. An alternative interpretation of this negative coefficient is the following: if there were no differences in the returns to education between the PS and private sector for females in Belgium, average wage differentials would increase by $0.0214(18.9 \%)$.
} 
Netherlands and UK) where the gaps remain positive but are smaller- between $11 \%$ and $29 \%$ for women and between $7 \%$ and $20 \%$ for men. Finally, in Denmark the gap is negative (i.e., wages are higher in the private sector) for both genders while in Germany it is negative only for men.

2. The Blinder-Oaxaca decomposition reveals that a large proportion of the positive gap between the wages in the PS and the private sector can be explained by differences in characteristics. In other words, the main reason why both women and men earn more (on average) in PS jobs than in private sector jobs is that PS employees have higher human capital - in terms of age, education and tenure- and, in addition, work in occupations and industries where average wages tend to be higher. Conversely, taken as a whole, the differences in returns to characteristics do not seem to contribute much to explaining the gap, although there is some variation across countries regarding the precise contribution of the explained and unexplained components.

\section{TRANSITIONS BETWEEN NON-WORKING AND PUBLIC /PRIVATE SECTOR JOBS}

The panel structure of our dataset allows us to identify transitions between any of the possible labour market states (out-of-the labour force, unemployment, Private Sector employment and PS employment). In the previous sections, so far we have provided quite a comprehensive static picture of the patterns of public versus private sector jobs from a gender perspective. However, according to Hypothesis (a) in the Introduction, PS employment may be attractive for women as entry jobs since it can help them to fight statistical discrimination by signalling their true productivity in this kind of jobs. Further, if that were to be the case, it can also help them in transiting at a later stage from the PS to the private sector. Yet, in order to examine whether there is empirical evidence supporting this hypothesis, a panel with a long time series dimension would be required. Unfortunately, ECHP is not the most appropriate dataset to look into this issue. On the one hand, the time span covered by the panel extends only for 8 years (from 1994 to 2001), and therefore, it is unlikely to capture the sort of transitions earlier described. On the other, there is a very high attrition in the dataset, which makes it difficult to carry out a robust analysis of multispell transitions.

Having said that, it is still interesting to present, during the available sample period and for each of the ECHP countries, some descriptive statistics on the proportion of male and female 
workers that are subject to any of the above-mentioned labour market transitions. ${ }^{10}$ Table 8 presents these transitions in relative terms (percentages) whereas the absolute numbers of transitions acrosslong the different labour market states are displayed in Table A3 of the Appendix.

We consider each possible transition by a worker as an independent spell. That is, we take into account all possible transitions between different labour market states of a worker between any wave of ECHP and the next consecutive one, conditional on having been observed in both waves.

The transitions are displayed as follows: for each country we report all observed transitions from any of the initial states in any period $t$ (working in the private sector, working in the PS, unemployment, inactivity) to any of the possible states (including no transition) at period $t+1$, insofar as the individual is observed during two consecutive waves.

The first panel in Table 8 presents the distribution of workers who, conditional on working in the private sector at any time $t$, either: (i) remain in the Private Sector at $t+1$, (ii) change to the PS at $t+1$, (iii) become unemployed at $t+1$ or (iv) withdraw from the labour force at $t+1$. The second panel presents the observed patterns of similar transitions this time conditional on working in the PS at any time $t$. The third panel presents the relative frequency of transitions from unemployment to the PS versus unemployment to the Private Sector. Finally, the last panel shows transitions to either PS or Private Sector that individuals make at any time $t+1$ when their initial situation at $t$ is out-of- the labour force. ${ }^{11}$

The first finding to highlight is that transitions from the Private Sector to the PS are very scarce - around $2-3 \%$ in most countries. Alternatively, conditional on working in the Private Sector in the first period when time they are observed, about $97-98 \%$ of workers remain in this sector. A clear exception to this pattern is Sweden, where a relatively high percentage of workers experience transitions from the Private Sector to the PS (43\% of females and 17\% of males).

Secondly, transitions from the PS to the Private sector are more frequent - between 5\% and $10 \%$ - but not very common either. Again, Sweden represents an outlier with $38 \%$ of women and $68 \%$ of males making this type of transition.

\footnotetext{
10 The observed period is at most eight years (from 1994 to 2001), except in Sweden, where only 5 years (from 1997 to 2001) are available. However, given that the ECHP is an unbalanced panel, most individuals are not observed in all waves.

${ }^{11}$ Unfortunately, we must restrict these descriptive to only one possible spell, given that there are very few individuals for whom we observe two transitions or more whereas observed.
} 
Thirdly, when making gender comparisons, it is found that females transit into the PS at a higher rate than males. To see this, it is useful to compare odds ratios between the alternative employment states. Take for example the case of Germany. In the third panel of this country in Table 8, we have that among German women who leave unemployment, $28.3 \%$ end up getting a job in the PS and $71.7 \%$ in the Private Sector. Thus, the odds ratio of a transition to the former is $28.3 / 71,7=0.39$. In the case of German men, this odds ratio is $12.9 / 87.1=0.15$. Hence, German female unemployed seek PS jobs about 2.5 times more intensively that their male counterparts. It can be easily checked that similar patterns occur for all countries in our sample and not only for transitions from unemployment to the two employment sectors but also from inactivity. These differences are particularly striking in the two Scandinavian countries where the female odds ratio is five times larger than the male one. This descriptive evidence therefore supports the first part of Hypothesis (a), which in turn could be explained by Hypotheses (b) to (c). Regarding the second stage, if we take Germany again for illustrative purposes, the second panel of Table 8 for this country shows that the odds ratio of a German woman to transit from PS to Private Sector is $5.6 / 88.3=0.06$ which is very similar to the male odds ratio, namely $6.9 / 89.2=0.08$. Most countries exhibit a similar pattern with the exception of Sweden where the female odds ratio of this type of transition is 4.5 times smaller than for men.

Overall, this admittedly descriptive evidence seems to point out that the PS is an employment magnet for women who are not working but also that it is a rather absorbing state in the sense that getting a job in this sector does not increase their transitions to Private Sector jobs, relative to men's. 
Table 8. Transitions between non-working, working in the PS and working in the private sector $(\%)$

\begin{tabular}{|c|c|c|c|c|c|c|c|c|c|}
\hline & \multicolumn{3}{|c|}{ Belgium } & \multicolumn{3}{|c|}{ Denmark } & \multicolumn{3}{|c|}{ France } \\
\hline & All & Females & Males & All & Females & Males & All & Females & Males \\
\hline \multicolumn{10}{|l|}{ Transitions Private sector } \\
\hline Private-Private & $92.07 \%$ & $89.21 \%$ & $94.06 \%$ & $93.14 \%$ & $89.62 \%$ & $95.13 \%$ & $92.02 \%$ & $89.30 \%$ & $93.87 \%$ \\
\hline Private-Public & $2.77 \%$ & $3.63 \%$ & $2.17 \%$ & $2.15 \%$ & $3.19 \%$ & $1.57 \%$ & $0.49 \%$ & $0.51 \%$ & $0.48 \%$ \\
\hline Private - Unemployed & $2.37 \%$ & $2.95 \%$ & $1.96 \%$ & $2.27 \%$ & $3.16 \%$ & $1.77 \%$ & $3.21 \%$ & $3.82 \%$ & $2.79 \%$ \\
\hline Private - Inactive & $2.80 \%$ & $4.21 \%$ & $1.82 \%$ & $2.43 \%$ & $4.02 \%$ & $1.53 \%$ & $4.29 \%$ & $6.38 \%$ & $2.86 \%$ \\
\hline Total & $100.00 \%$ & $100.00 \%$ & $100.00 \%$ & $100.00 \%$ & $100.00 \%$ & $100.00 \%$ & $100.00 \%$ & $100.00 \%$ & $100.00 \%$ \\
\hline \multicolumn{10}{|l|}{ Transitions Public sector } \\
\hline Public-Public & $91.62 \%$ & $89.83 \%$ & $93.57 \%$ & $91.54 \%$ & $91.61 \%$ & $91.39 \%$ & $93.76 \%$ & $92.98 \%$ & $94.71 \%$ \\
\hline Public-Private & $5.58 \%$ & $5.98 \%$ & $5.15 \%$ & $3.42 \%$ & $2.63 \%$ & $4.94 \%$ & $1.20 \%$ & $1.10 \%$ & $1.31 \%$ \\
\hline Public - Unemployed & $0.80 \%$ & $1.18 \%$ & $0.39 \%$ & $1.73 \%$ & $1.78 \%$ & $1.63 \%$ & $1.73 \%$ & $1.99 \%$ & $1.43 \%$ \\
\hline Public - Inactive & $2.00 \%$ & $3.01 \%$ & $0.89 \%$ & $3.31 \%$ & $3.98 \%$ & $2.04 \%$ & $3.31 \%$ & $3.94 \%$ & $2.54 \%$ \\
\hline Total & $100.00 \%$ & $100.00 \%$ & $100.00 \%$ & $100.00 \%$ & $100.00 \%$ & $100.00 \%$ & $100.00 \%$ & $100.00 \%$ & $100.00 \%$ \\
\hline \multicolumn{10}{|l|}{ Transitions Unemployed } \\
\hline Unemployed - Private & $72.75 \%$ & $67.38 \%$ & $79.59 \%$ & $62.67 \%$ & $48.95 \%$ & $78.82 \%$ & $78.39 \%$ & $73.74 \%$ & $83.67 \%$ \\
\hline Unemployed - Public & $27.25 \%$ & $32.62 \%$ & $20.41 \%$ & $37.33 \%$ & $51.05 \%$ & $21.18 \%$ & $21.61 \%$ & $26.26 \%$ & $16.33 \%$ \\
\hline Total & $100.00 \%$ & $100.00 \%$ & $100.00 \%$ & $100.00 \%$ & $100.00 \%$ & $100.00 \%$ & $100.00 \%$ & $100.00 \%$ & $100.00 \%$ \\
\hline \multicolumn{10}{|l|}{ Transitions Inactive } \\
\hline Inactive - Private & $76.11 \%$ & $73.53 \%$ & $79.17 \%$ & $44.69 \%$ & $38.49 \%$ & $59.35 \%$ & $73.17 \%$ & $68.67 \%$ & $79.35 \%$ \\
\hline Inactive - Public & $23.89 \%$ & $26.47 \%$ & $20.83 \%$ & $55.31 \%$ & $61.51 \%$ & $40.65 \%$ & $26.83 \%$ & $31.33 \%$ & $20.65 \%$ \\
\hline Total & $100.00 \%$ & $100.00 \%$ & $100.00 \%$ & $100.00 \%$ & $100.00 \%$ & $100.00 \%$ & $100.00 \%$ & $100.00 \%$ & $100.00 \%$ \\
\hline
\end{tabular}

\begin{tabular}{|c|c|c|c|c|c|c|c|c|c|}
\hline & \multicolumn{3}{|c|}{ Germany } & \multicolumn{3}{|c|}{ Greece } & \multicolumn{3}{|c|}{ Ireland } \\
\hline & All & Females & Males & All & Females & Males & All & Females & Males \\
\hline \multicolumn{10}{|l|}{ Transitions Private sector } \\
\hline Private-Private & $91.82 \%$ & $89.60 \%$ & $93.19 \%$ & $90.93 \%$ & $85.37 \%$ & $93.80 \%$ & $90.50 \%$ & $86.42 \%$ & $93.11 \%$ \\
\hline Private-Public & $1.75 \%$ & $2.48 \%$ & $1.29 \%$ & $1.91 \%$ & $2.35 \%$ & $1.68 \%$ & $2.54 \%$ & $3.34 \%$ & $2.03 \%$ \\
\hline Private - Unemployed & $2.86 \%$ & $3.05 \%$ & $2.75 \%$ & $3.62 \%$ & $4.69 \%$ & $3.06 \%$ & $2.67 \%$ & $2.74 \%$ & $2.63 \%$ \\
\hline Private - Inactive & $3.57 \%$ & $4.87 \%$ & $2.77 \%$ & $3.54 \%$ & $7.59 \%$ & $1.46 \%$ & $4.29 \%$ & $7.50 \%$ & $2.23 \%$ \\
\hline Total & $100.00 \%$ & $100.00 \%$ & $100.00 \%$ & $100.00 \%$ & $100.00 \%$ & $100.00 \%$ & $100.00 \%$ & $100.00 \%$ & $100.00 \%$ \\
\hline \multicolumn{10}{|l|}{ Transitions Public sector } \\
\hline Public-Public & $88.70 \%$ & $88.34 \%$ & $89.18 \%$ & $92.44 \%$ & $92.39 \%$ & $92.47 \%$ & $89.74 \%$ & $88.86 \%$ & $90.44 \%$ \\
\hline Public-Private & $6.15 \%$ & $5.63 \%$ & $6.85 \%$ & $4.47 \%$ & $4.04 \%$ & $4.74 \%$ & $6.54 \%$ & $6.83 \%$ & $6.31 \%$ \\
\hline Public - Unemployed & $1.84 \%$ & $2.18 \%$ & $1.39 \%$ & $1.15 \%$ & $1.50 \%$ & $0.92 \%$ & $1.38 \%$ & $1.26 \%$ & $1.47 \%$ \\
\hline Public - Inactive & $3.31 \%$ & $3.86 \%$ & $2.58 \%$ & $1.94 \%$ & $2.06 \%$ & $1.87 \%$ & $2.34 \%$ & $3.05 \%$ & $1.78 \%$ \\
\hline Total & $100.00 \%$ & $100.00 \%$ & $100.00 \%$ & $100.00 \%$ & $100.00 \%$ & $100.00 \%$ & $100.00 \%$ & $100.00 \%$ & $100.00 \%$ \\
\hline \multicolumn{10}{|l|}{ Transitions Unemployed/Inac } \\
\hline Unemployed - Private & $79.62 \%$ & $71.70 \%$ & $87.06 \%$ & $87.82 \%$ & $85.78 \%$ & $89.60 \%$ & $80.83 \%$ & $78.22 \%$ & $82.46 \%$ \\
\hline Unemployed - Public & $20.38 \%$ & $28.30 \%$ & $12.94 \%$ & $12.18 \%$ & $14.22 \%$ & $10.40 \%$ & $19.17 \%$ & $21.78 \%$ & $17.54 \%$ \\
\hline Total & $100.00 \%$ & $100.00 \%$ & $100.00 \%$ & $100.00 \%$ & $100.00 \%$ & $100.00 \%$ & $100.00 \%$ & $100.00 \%$ & $100.00 \%$ \\
\hline \multicolumn{10}{|l|}{ Transitions Inactive } \\
\hline Inactive - Private & $75.12 \%$ & $69.20 \%$ & $83.53 \%$ & $88.11 \%$ & $88.87 \%$ & $86.59 \%$ & $80.34 \%$ & $77.13 \%$ & $87.19 \%$ \\
\hline Inactive - Public & $24.88 \%$ & $30.80 \%$ & $16.47 \%$ & $11.89 \%$ & $11.13 \%$ & $13.41 \%$ & $19.66 \%$ & $22.87 \%$ & $12.81 \%$ \\
\hline Total & $100.00 \%$ & $100.00 \%$ & $100.00 \%$ & $100.00 \%$ & $100.00 \%$ & $100.00 \%$ & $100.00 \%$ & $100.00 \%$ & $100.00 \%$ \\
\hline
\end{tabular}


Table 8 (cont.) Transitions between non-working, working in the PS and working in the Private Sector $(\%)$

\begin{tabular}{|c|c|c|c|c|c|c|c|c|c|}
\hline & \multicolumn{3}{|c|}{ Italy } & \multicolumn{3}{|c|}{ Netherlands } & \multicolumn{3}{|c|}{ Portugal } \\
\hline & All & Females & Males & All & Females & Males & All & Females & Males \\
\hline \multicolumn{10}{|l|}{ Transitions Private sector } \\
\hline Private-Private & $92.72 \%$ & $89.74 \%$ & $94.22 \%$ & $92.79 \%$ & $88.09 \%$ & $95.39 \%$ & $92.92 \%$ & $89.69 \%$ & $95.00 \%$ \\
\hline Private-Public & $1.69 \%$ & $1.91 \%$ & $1.58 \%$ & $3.73 \%$ & $6.30 \%$ & $2.30 \%$ & $2.58 \%$ & $3.34 \%$ & $2.09 \%$ \\
\hline Private - Unemployed & $2.81 \%$ & $3.44 \%$ & $2.50 \%$ & $0.87 \%$ & $1.21 \%$ & $0.69 \%$ & $1.71 \%$ & $2.19 \%$ & $1.41 \%$ \\
\hline Private - Inactive & $2.78 \%$ & $4.92 \%$ & $1.70 \%$ & $2.61 \%$ & $4.39 \%$ & $1.62 \%$ & $2.78 \%$ & $4.78 \%$ & $1.50 \%$ \\
\hline Total & $100.00 \%$ & $100.00 \%$ & $100.00 \%$ & $100.00 \%$ & $100.00 \%$ & $100.00 \%$ & $100.00 \%$ & $100.00 \%$ & $100.00 \%$ \\
\hline \multicolumn{10}{|l|}{ Transitions Public sector } \\
\hline Public-Public & $92.53 \%$ & $93.87 \%$ & $91.43 \%$ & $87.33 \%$ & $85.10 \%$ & $89.58 \%$ & $87.40 \%$ & $88.58 \%$ & $86.06 \%$ \\
\hline Public-Private & $3.99 \%$ & $2.92 \%$ & $4.87 \%$ & $10.30 \%$ & $11.89 \%$ & $8.71 \%$ & $9.12 \%$ & $7.69 \%$ & $10.73 \%$ \\
\hline Public - Unemployed & $1.08 \%$ & $1.22 \%$ & $0.96 \%$ & $0.67 \%$ & $0.62 \%$ & $0.71 \%$ & $1.11 \%$ & $1.31 \%$ & $0.88 \%$ \\
\hline Public - Inactive & $2.40 \%$ & $1.99 \%$ & $2.75 \%$ & $1.70 \%$ & $2.38 \%$ & $1.01 \%$ & $2.38 \%$ & $2.42 \%$ & $2.33 \%$ \\
\hline Total & $100.00 \%$ & $100.00 \%$ & $100.00 \%$ & $100.00 \%$ & $100.00 \%$ & $100.00 \%$ & $100.00 \%$ & $100.00 \%$ & $100.00 \%$ \\
\hline \multicolumn{10}{|l|}{ Transitions Unemployed/Inac } \\
\hline Unemployed - Private & $81.29 \%$ & $75.73 \%$ & $85.32 \%$ & $79.48 \%$ & $76.30 \%$ & $83.33 \%$ & $82.41 \%$ & $82.84 \%$ & $81.94 \%$ \\
\hline Unemployed - Public & $18.71 \%$ & $24.27 \%$ & $14.68 \%$ & $20.52 \%$ & $23.70 \%$ & $16.67 \%$ & $17.59 \%$ & $17.16 \%$ & $18.06 \%$ \\
\hline Total & $100.00 \%$ & $100.00 \%$ & $100.00 \%$ & $100.00 \%$ & $100.00 \%$ & $100.00 \%$ & $100.00 \%$ & $100.00 \%$ & $100.00 \%$ \\
\hline \multicolumn{10}{|l|}{ Transitions Inactive } \\
\hline Inactive - Private & $18.08 \%$ & $22.27 \%$ & $80.18 \%$ & $80.92 \%$ & $76.01 \%$ & $88.58 \%$ & $77.66 \%$ & $75.77 \%$ & $80.88 \%$ \\
\hline Inactive - Public & $4.48 \%$ & $5.53 \%$ & $19.82 \%$ & $19.08 \%$ & $23.99 \%$ & $11.42 \%$ & $22.34 \%$ & $24.23 \%$ & $19.12 \%$ \\
\hline Total & $22.57 \%$ & $27.80 \%$ & $100.00 \%$ & $100.00 \%$ & $100.00 \%$ & $100.00 \%$ & $100.00 \%$ & $100.00 \%$ & $100.00 \%$ \\
\hline
\end{tabular}

\begin{tabular}{|c|c|c|c|c|c|c|c|c|c|}
\hline & \multicolumn{3}{|c|}{ Spain } & \multicolumn{3}{|c|}{ Sweden $^{1}$} & \multicolumn{3}{|c|}{ United Kingdom } \\
\hline & All & Females & Males & All & Females & Males & All & Females & Males \\
\hline \multicolumn{10}{|l|}{ Transitions Private sector } \\
\hline Private-Private & $88.95 \%$ & $83.59 \%$ & $91.50 \%$ & $50.65 \%$ & $36.69 \%$ & $66.05 \%$ & $90.88 \%$ & $86.75 \%$ & $93.90 \%$ \\
\hline Private-Public & $1.93 \%$ & $2.61 \%$ & $1.61 \%$ & $30.75 \%$ & $43.18 \%$ & $17.05 \%$ & $1.94 \%$ & $2.93 \%$ & $1.22 \%$ \\
\hline Private - Unemployed & $5.69 \%$ & $7.10 \%$ & $5.01 \%$ & $9.18 \%$ & $8.97 \%$ & $9.41 \%$ & $1.78 \%$ & $1.78 \%$ & $1.78 \%$ \\
\hline Private - Inactive & $3.43 \%$ & $6.70 \%$ & $1.88 \%$ & $9.41 \%$ & $11.15 \%$ & $7.50 \%$ & $5.40 \%$ & $8.53 \%$ & $3.11 \%$ \\
\hline Total & $100.00 \%$ & $100.00 \%$ & $100.00 \%$ & $100.00 \%$ & $100.00 \%$ & $100.00 \%$ & $100.00 \%$ & $100.00 \%$ & $100.00 \%$ \\
\hline \multicolumn{10}{|l|}{ Transitions Public sector } \\
\hline Public-Public & $87.77 \%$ & $87.63 \%$ & $87.89 \%$ & $27.05 \%$ & $38.43 \%$ & $15.04 \%$ & $88.66 \%$ & $88.77 \%$ & $88.47 \%$ \\
\hline Public-Private & $7.58 \%$ & $6.84 \%$ & $8.17 \%$ & $52.64 \%$ & $38.36 \%$ & $67.72 \%$ & $6.08 \%$ & $5.35 \%$ & $7.40 \%$ \\
\hline Public - Unemployed & $2.76 \%$ & $3.28 \%$ & $2.35 \%$ & $8.43 \%$ & $8.88 \%$ & $7.95 \%$ & $0.73 \%$ & $0.70 \%$ & $0.80 \%$ \\
\hline Public - Inactive & $1.88 \%$ & $2.25 \%$ & $1.59 \%$ & $11.88 \%$ & $14.33 \%$ & $9.29 \%$ & $4.53 \%$ & $5.18 \%$ & $3.34 \%$ \\
\hline Total & $100.00 \%$ & $100.00 \%$ & $100.00 \%$ & $100.00 \%$ & $100.00 \%$ & $100.00 \%$ & $100.00 \%$ & $100.00 \%$ & $100.00 \%$ \\
\hline \multicolumn{10}{|l|}{ Transitions Unemployed/Inac } \\
\hline Unemployed - Private & $85.52 \%$ & $83.58 \%$ & $90.68 \%$ & $64.36 \%$ & $47.99 \%$ & $82.07 \%$ & $88.41 \%$ & $83.77 \%$ & $90.81 \%$ \\
\hline Unemployed - Public & $14.48 \%$ & $16.42 \%$ & $9.32 \%$ & $35.64 \%$ & $52.01 \%$ & $17.93 \%$ & $11.59 \%$ & $16.23 \%$ & $9.19 \%$ \\
\hline Total & $100.00 \%$ & $100.00 \%$ & $100.00 \%$ & $100.00 \%$ & $100.00 \%$ & $100.00 \%$ & $100.00 \%$ & $100.00 \%$ & $100.00 \%$ \\
\hline \multicolumn{10}{|l|}{ Transitions Inactive } \\
\hline Inactive - Private & $85.94 \%$ & $85.24 \%$ & $87.12 \%$ & $64.38 \%$ & $48.34 \%$ & $80.00 \%$ & $78.08 \%$ & $74.83 \%$ & $85.71 \%$ \\
\hline Inactive - Public & $14.06 \%$ & $14.76 \%$ & $12.88 \%$ & $35.62 \%$ & $51.66 \%$ & $20.00 \%$ & $21.92 \%$ & $25.17 \%$ & $14.29 \%$ \\
\hline Total & $100.00 \%$ & $100.00 \%$ & $100.00 \%$ & $100.00 \%$ & $100.00 \%$ & $100.00 \%$ & $100.00 \%$ & $100.00 \%$ & $100.00 \%$ \\
\hline
\end{tabular}

Notes: 1. For Sweden there are only four waves (1997-2001)

\section{CONCLUSIONS}

We started this paper with four main hypotheses in mind (a to d), which could help us to organize our thoughts about the evidence we have presented about the effect of PS employment on women's labor outcomes. These four hypotheses relate to (a) the role of the PS in offsetting statistical discrimination, (b) differences in pecuniary and (c) non-pecuniary conditions in the PS vs. private sector, and (d) gender differences in preferences for working in the PS.

What have we learnt about them in the light of the reported evidence?

The main conclusion seems to be that, though we did not find any evidence in favor of Hypothesis (d), no single hypothesis seems to be able to explain all reported facts in all countries. For example, all else equal, PS employment seems to be relatively more attractive for women vis-àvis men in the Nordic countries, Germany, Ireland and Portugal, while it is less attractive in Italy, Spain and The Netherlands, with no significant differences being observed in the remaining other 
countries. However, the evidence reported about transitions seems to indicate that unemployed or inactive women seek for PS jobs more intensively than men. Yet, this does not help them, relative to men, to transit to private sector jobs. One important reason for the former effect seems to be that PS employment may provide compensating differentials, in terms of reconciling family and work duties, as reflected by the fact the PS attracts older women who are married and have children. This result would be consistent with Hypothesis (c).

As for education levels, there is a significant group of countries (Italy, Spain, Sweden and UK) where the PS attracts both higher educated men and women. In other countries, like Denmark and The Netherlands, there are important gender differences in this respect but, in contrast to the previous set of countries, the PS attracts more educated men, but not necessarily more educated women. Finally, in countries such as Belgium, France and Portugal, the level of education does not seem to be a relevant determinant for the choice of PS vs. private sector job. Overall, this fragmentary evidence seemingly points out that PS employment does not uniformly offset statistical discrimination across all countries since that would imply attracting more educated women who wish to ensure labor market returns to their large human capital investment.

With regard to wages, we find that female wages in the PS are either higher or not significantly different from those in the private sector, once other observables are controlled for, with the exception of Denmark, where women in the PS earn 20\% less on average than those in the private sector. Hence, in line with Hypothesis (b), this evidence points out that women who work in the PS fare much better in terms of wages than those with similar characteristics who choose to work in the private sector. For men, working in the PS is less advantageous in terms of wages than for women. Indeed, in most countries, male wage gaps between the two sectors are not significantly different from zero.

When comparing gender wage gaps between the two sectors, we find that they are much larger in the private sector than in the PS except in France and The Netherlands where they are similar, and in Denmark where the gender wage gap in the PS is much higher. Blinder-Oaxaca decompositions reveal that a large proportion of the positive gap between wages in PS and private sector jobs observed in some countries can be almost exclusively explained by differences in characteristics since men and women in PS jobs tend to have more human capital on average than in the private sector. 


\section{References:}

Albrecht, J., Björklund, A., and S. Vroman (2003), “Is there a Glass Ceiling in Sweden?”, Journal of Labor Economics.

Ehrenberg, Ronald G. and Joshua L. Schwartz (1986), "Public Sector Labor Markets", in O. Ashenfelter and R. Layard, eds., Handbook of Labor Economics, vol. 2, pp: 1219-1268

Freeman, Richard B. (1986), "Unionism comes to the Public Sector", Journal of Economic Literature, 24: 41-86.

Freeman, Richard B. and C. Ichniowski (1988), "Introduction: The Public Sector look of American Unionism", in R. Freeman and C. Ichniowski, eds., When Public Sector Workers Unionize (University of Chicago Press, Chicago, IL), pp: 1-15

Gneezy, U., Niederle, M, and A. Rustichini (2003), "Performance in Competitive Environments: Gender Differences", Quarterly Journal of Economics, 118, 1049-1074.

Gornick, Janet C. and Jerry A. Jacobs (1998), "Gender, The Welfare State and Public Employment: A comparative study of seven industrialized Countries", American Sociological Review, 63 (5), pp: $688-710$

Gregory, Robert G. and J. Borland (1995), "Recent Developments in Public Sector Labor Markets", in O. Ashenfelter and D. Card, eds., Handbook of Labor Economics, vol. 3C, pp: $3573-3630$

Gunderson, M. (1995), "Public Sector Compensation”, in G. Swimmer and Thompson, eds., Public Sector Collective Bargaining in Canada (IRC Press, Kingston), pp: 103-134

Postel-Vinay, F. and H. Turon, 2007, “The Public Pay Gap in Britain: Small Differences That (Don't) Matter", Economic Journal, 117, pp: 1460-503.

Rosen, S. (1996), "Public Employment and the Welfare State in Sweden", Journal of Economic Literature, vol.34 (3), pp: 729-740.

Schelling, T.C., (1971), "Dynamic Models of Segregation”, Journal of Mathematical Sociology, 1, 143186. 


\section{Appendix}

Figure A1. \% PS Employment in Total Employment, according to Laborsta data

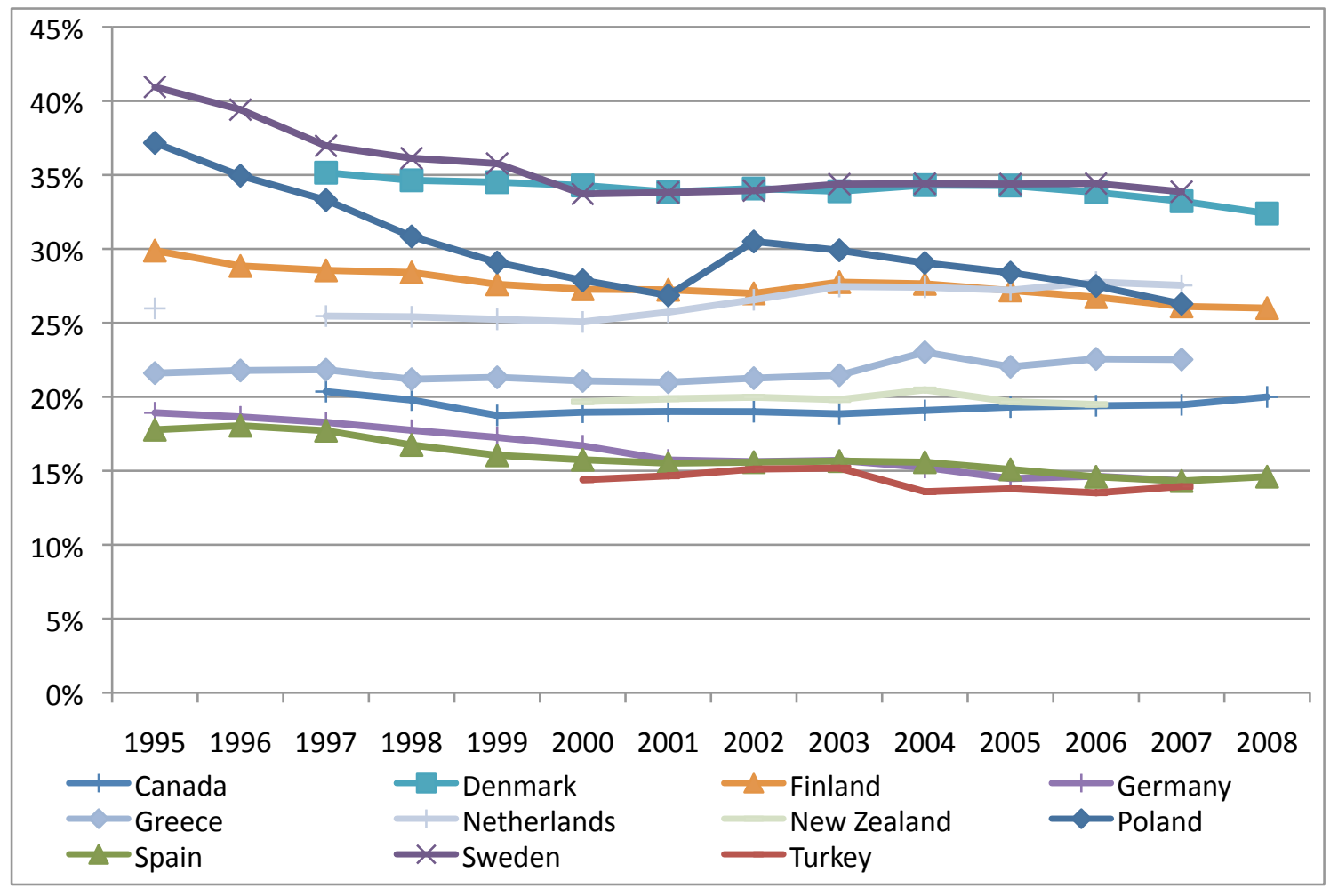

Source: ILO - Laborsta 
Figure A2. \% Female PS Employment in Total Public Employment, according to Laborsta data

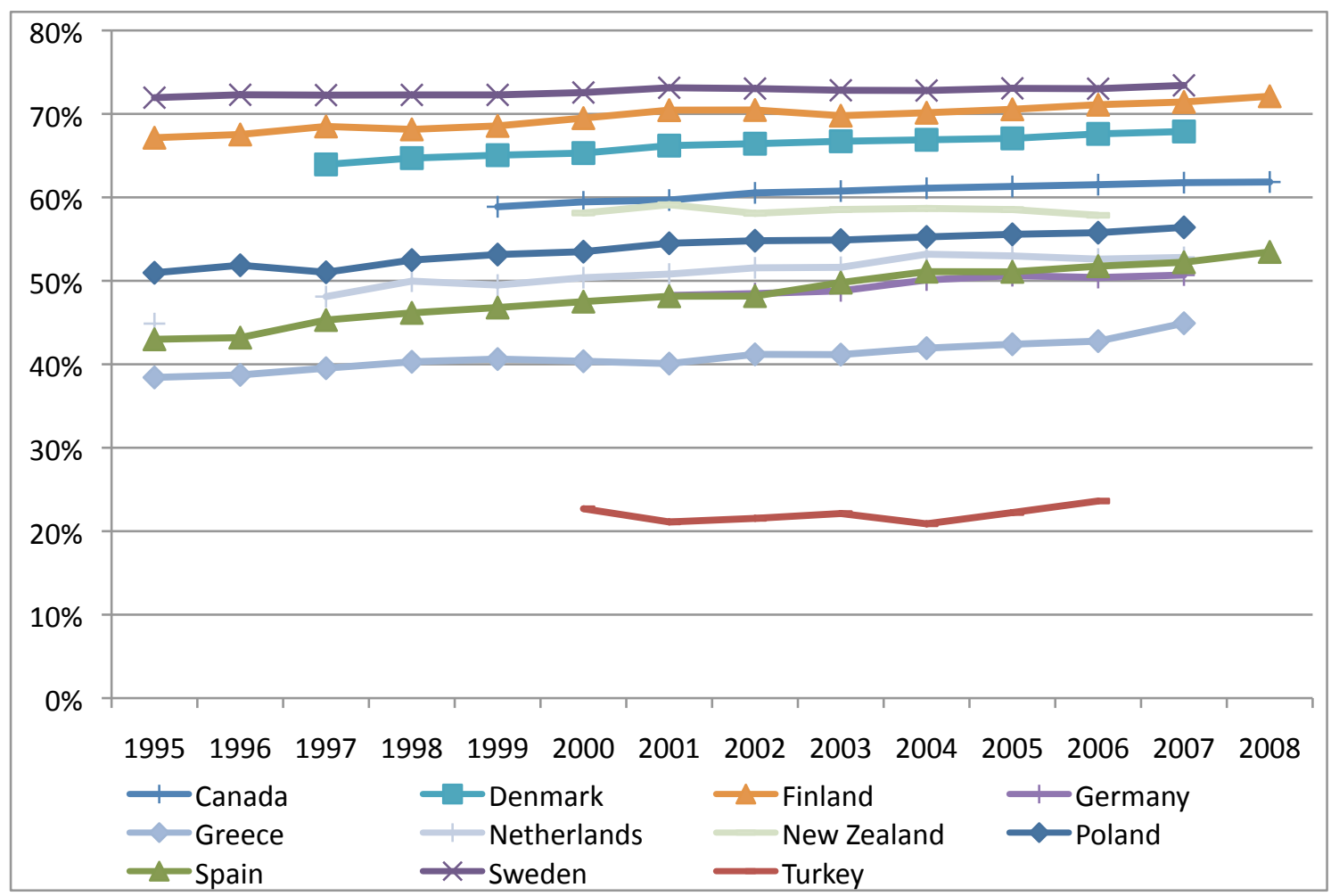

Source: ILO - Laborsta 
Figure A3. \% Public Administration and Defence Employment in Total Employment, according to OECD data

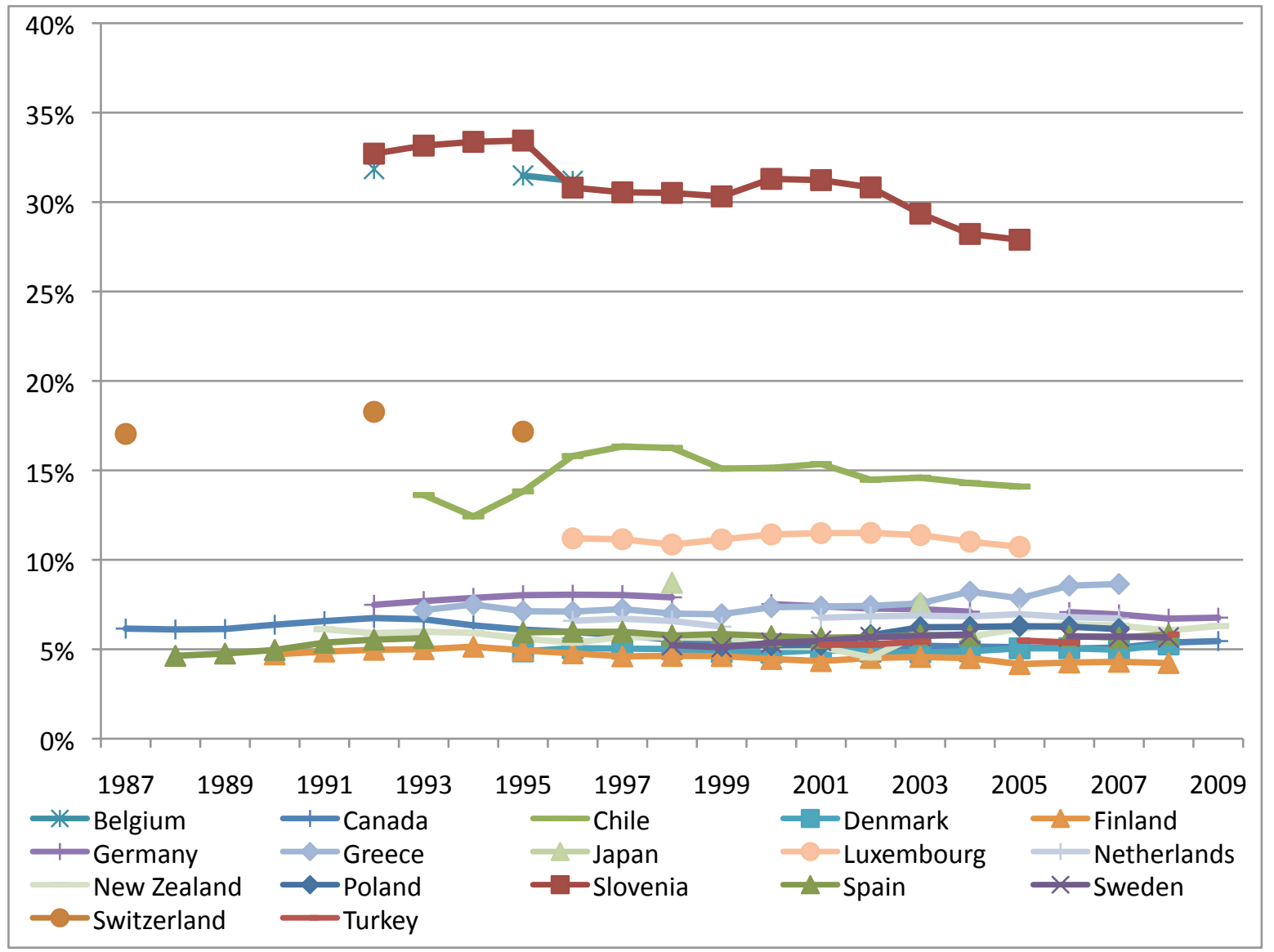

Source: OECD 
Figure A4. \% Female Public Administration and Defence Employment in Total Public Administration and Defence Employment, according to OECD data

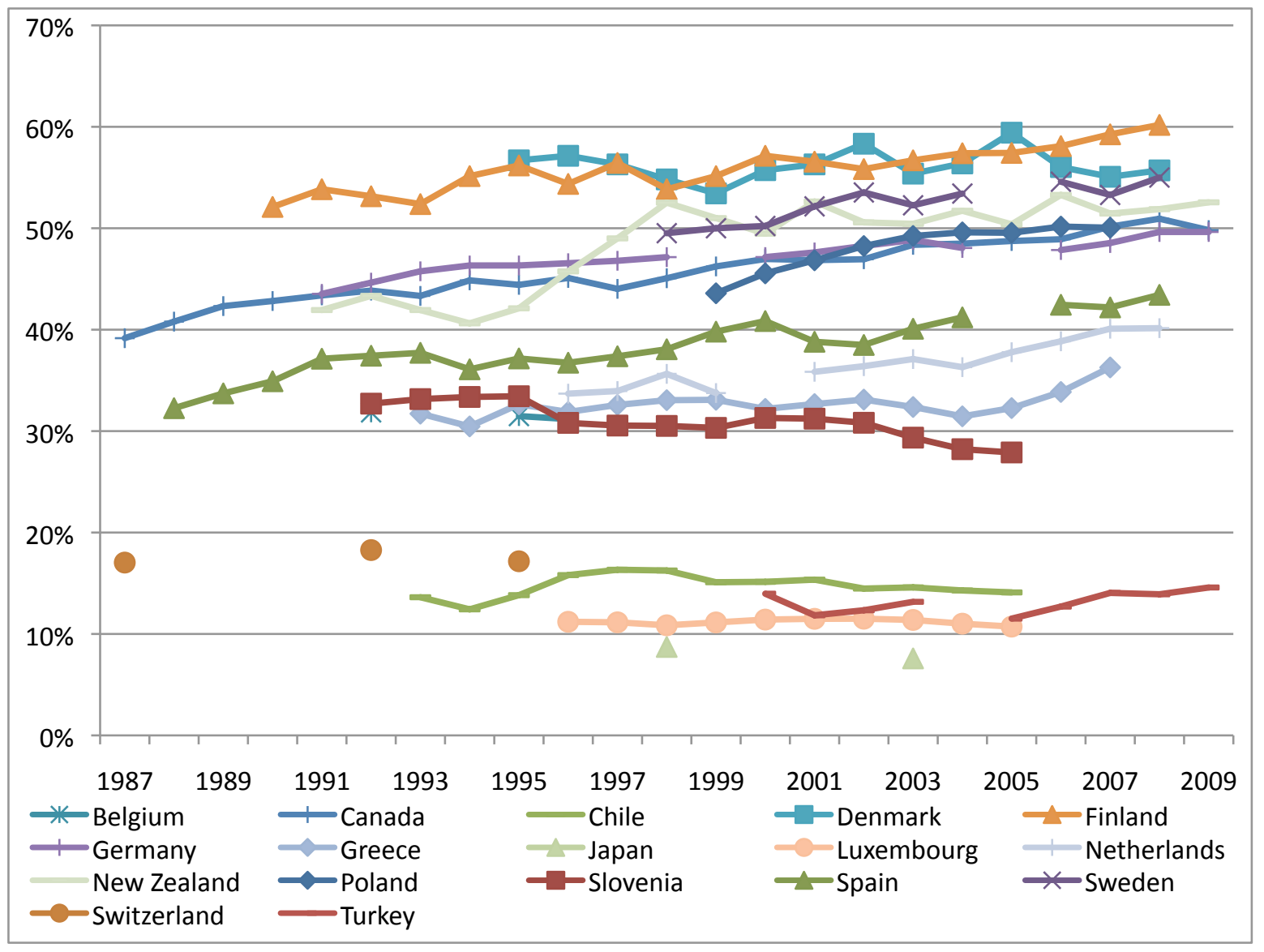

Source: OECD 
Table A1. Oaxaca-Blinder Wage Decomposition, disaggregated

\begin{tabular}{|c|c|c|c|c|c|c|c|c|}
\hline & \multicolumn{4}{|c|}{ Belgium } & \multicolumn{4}{|c|}{ Denmark } \\
\hline & \multicolumn{2}{|c|}{ Females } & \multicolumn{2}{|c|}{ Males } & \multicolumn{2}{|c|}{ Females } & \multicolumn{2}{|c|}{ Males } \\
\hline & \multicolumn{2}{|c|}{$\begin{array}{c}\text { Log wage gap between public and private } \\
\text { sectors }=0.1134\end{array}$} & \multicolumn{2}{|c|}{$\begin{array}{c}\text { Log wage gap between public and private } \\
\text { sectors }=0.0680\end{array}$} & \multicolumn{2}{|c|}{$\begin{array}{c}\text { Log wage gap between public and private } \\
\text { sectors }=-0.1050\end{array}$} & \multicolumn{2}{|c|}{$\begin{array}{c}\text { Log wage gap between public and private } \\
\text { sectors }=-0.0265\end{array}$} \\
\hline Variables & $\begin{array}{l}\text { Explained part (gap } \\
\text { in endowments) }\end{array}$ & Unexplained part & $\begin{array}{l}\text { Explained part (gap } \\
\text { in endowments) }\end{array}$ & Unexplained part & \begin{tabular}{|l|} 
Explained part (gap \\
in endowments)
\end{tabular} & Unexplained part & $\begin{array}{c}\text { Explained part (gap } \\
\text { in endowments) }\end{array}$ & Unexplained part \\
\hline \multirow[t]{2}{*}{ Age } & 0.0101 & -0.9706 & \begin{tabular}{|l|}
0.0074 \\
\end{tabular} & 0.1287 & \begin{tabular}{|l|}
-0.0090 \\
\end{tabular} & -1.5387 & \begin{tabular}{|l|}
0.0075 \\
\end{tabular} & -3.9998 \\
\hline & $8.87 \%$ & $-855.42 \%$ & $10.86 \%$ & $189.01 \%$ & $8.54 \%$ & $1464.36 \%$ & $-28.43 \%$ & $15069.23 \%$ \\
\hline \multirow[t]{2}{*}{ Married } & 0.0006 & -0.0045 & 0.0016 & -0.0087 & -0.0149 & 0.0032 & -0.0075 & 0.0006 \\
\hline & $0.53 \%$ & $-3.93 \%$ & $2.39 \%$ & $-12.76 \%$ & $14.16 \%$ & $-3.05 \%$ & $28.35 \%$ & $-2.37 \%$ \\
\hline \multirow[t]{2}{*}{ Children } & 0.0021 & 0.0230 & -0.0062 & 0.0061 & 0.0020 & -0.0150 & -0.0002 & -0.0019 \\
\hline & $1.85 \%$ & $20.24 \%$ & $-9.11 \%$ & $9.00 \%$ & $-1.93 \%$ & $14.26 \%$ & $0.59 \%$ & $7.04 \%$ \\
\hline \multirow{2}{*}{ Education } & 0.0225 & -0.0214 & 0.0406 & 0.0211 & 0.0204 & 0.0097 & 0.0067 & 0.0973 \\
\hline & $19.80 \%$ & $-18.90 \%$ & $59.57 \%$ & $31.02 \%$ & $-19.37 \%$ & $-9.25 \%$ & $-25.40 \%$ & $-366.66 \%$ \\
\hline \multirow[t]{2}{*}{ Tenure } & 0.0014 & -0.0461 & 0.0067 & 0.0631 & -0.0200 & 0.0112 & -0.0041 & 0.0100 \\
\hline & $1.21 \%$ & $-40.59 \%$ & $9.86 \%$ & $92.73 \%$ & $19.05 \%$ & $-10.67 \%$ & $15.48 \%$ & $-37.52 \%$ \\
\hline \multirow[t]{2}{*}{ Occupation } & 0.0696 & 0.0058 & 0.0660 & -0.0365 & 0.0152 & 0.0981 & 0.0182 & -0.0947 \\
\hline & $61.36 \%$ & $5.08 \%$ & $96.88 \%$ & $-53.56 \%$ & $-14.49 \%$ & $-93.33 \%$ & $-68.62 \%$ & $356.81 \%$ \\
\hline \multirow{2}{*}{ Sector of activity } & -0.0082 & 0.0602 & -0.0389 & -0.0388 & -0.0188 & 0.0926 & -0.0397 & -0.0807 \\
\hline & $-7.24 \%$ & $53.05 \%$ & $-57.21 \%$ & $-56.99 \%$ & $17.86 \%$ & $-88.09 \%$ & $149.55 \%$ & $304.21 \%$ \\
\hline \multirow{2}{*}{ Part-time/Full-time } & -0.0019 & -0.0091 & 0.0047 & -0.3826 & -0.0032 & 0.0818 & 0.0000 & 0.0000 \\
\hline & $-1.70 \%$ & $-7.99 \%$ & $6.88 \%$ & $-562.11 \%$ & $3.02 \%$ & $-77.83 \%$ & $0.00 \%$ & $0.00 \%$ \\
\hline \multirow{2}{*}{$\begin{array}{l}\text { Type of contract } \\
\text { (Perm./Temp.) }\end{array}$} & -0.0059 & 0.0601 & -0.0115 & -0.0686 & 0.0143 & -0.1495 & -0.0008 & 0.0265 \\
\hline & $-5.16 \%$ & $52.98 \%$ & $-16.96 \%$ & $-100.73 \%$ & $-13.57 \%$ & $142.32 \%$ & $3.07 \%$ & $-100.02 \%$ \\
\hline \multirow[t]{2}{*}{ Constant } & 0.0000 & 0.9258 & 0.0000 & 0.3140 & 0.0000 & 1.3155 & 0.0000 & 4.0359 \\
\hline & $0.00 \%$ & $815.96 \%$ & $0.00 \%$ & $461.21 \%$ & $0.00 \%$ & $-1251.98 \%$ & $0.00 \%$ & $-15205.30 \%$ \\
\hline \multirow[t]{2}{*}{ Total } & 0.0902 & 0.0232 & 0.0702 & -0.0022 & -0.0139 & -0.0911 & -0.0198 & -0.0067 \\
\hline & $79.52 \%$ & $20.48 \%$ & $103.17 \%$ & $-3.17 \%$ & $13.27 \%$ & $86.73 \%$ & $74.59 \%$ & $25.41 \%$ \\
\hline No. of observations & 419 & & 463 & & 89 & & 103 & \\
\hline
\end{tabular}

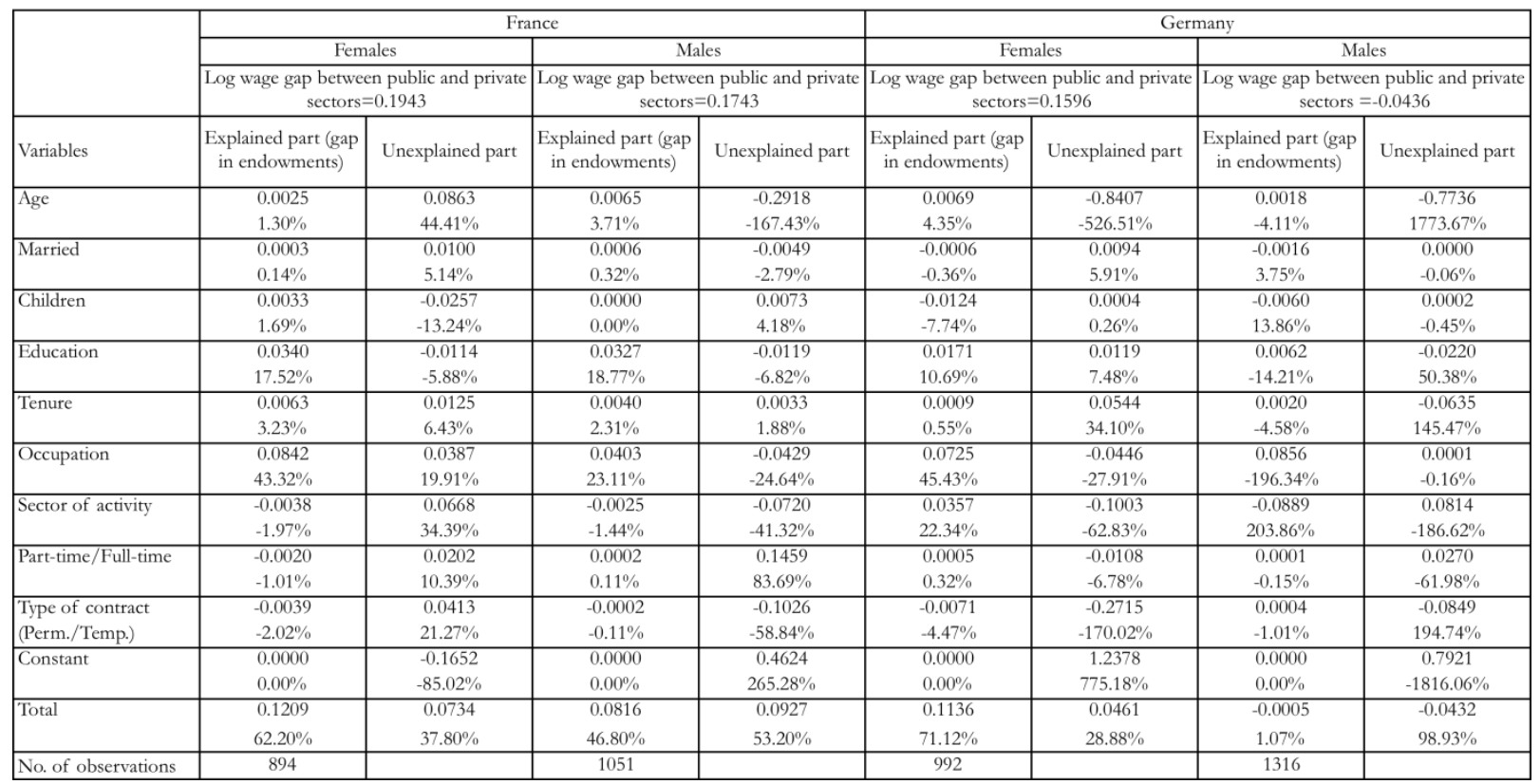


Table A1 (cont.)

\begin{tabular}{|c|c|c|c|c|c|c|c|c|}
\hline & \multicolumn{4}{|c|}{ Greece } & \multicolumn{4}{|c|}{ Ireland } \\
\hline & \multicolumn{2}{|c|}{ Females } & \multicolumn{2}{|c|}{ Males } & \multicolumn{2}{|c|}{ Females } & \multicolumn{2}{|c|}{ Males } \\
\hline & \multicolumn{2}{|c|}{$\begin{array}{l}\text { Log wage gap between public and private } \\
\text { sectors }=0.4783\end{array}$} & \multicolumn{2}{|c|}{$\begin{array}{c}\text { Log wage gap between public and private } \\
\text { sectors }=0.2945\end{array}$} & \multicolumn{2}{|c|}{$\begin{array}{l}\text { Log wage gap between public and private } \\
\text { sectors }=0.5016\end{array}$} & \multicolumn{2}{|c|}{$\begin{array}{l}\text { Log wage gap between public and private } \\
\text { sectors }=0.2649\end{array}$} \\
\hline Variables & $\begin{array}{c}\text { Explained part (gap in } \\
\text { endowments) }\end{array}$ & Unexplained part & $\begin{array}{c}\text { Explained part (gap in } \\
\text { endowments) }\end{array}$ & Unexplained part & $\begin{array}{c}\text { Explained part (gap in } \\
\text { endowments) }\end{array}$ & Unexplained part & $\begin{array}{c}\text { Explained part (gap in } \\
\text { endowments) }\end{array}$ & Unexplained part \\
\hline Age & \begin{tabular}{|l|}
0.0189 \\
$3.95 \%$ \\
\end{tabular} & $\begin{array}{c}-0.7159 \\
-149.67 \%\end{array}$ & \begin{tabular}{|l|}
0.0150 \\
$5.11 \%$
\end{tabular} & $\begin{array}{l}-0.8783 \\
-298.23 \%\end{array}$ & \begin{tabular}{|l|}
0.0024 \\
$0.48 \%$
\end{tabular} & $\begin{array}{r}2.0375 \\
406.18 \%\end{array}$ & $\begin{array}{l}0.0211 \\
7.98 \% \\
\end{array}$ & $\begin{array}{r}0.5909 \\
223.07 \%\end{array}$ \\
\hline Married & $\begin{array}{l}0.0001 \\
0.02 \%\end{array}$ & $\begin{array}{l}-0.0110 \\
-2.31 \%\end{array}$ & $\begin{array}{l}0.0033 \\
1.11 \%\end{array}$ & $\begin{array}{l}0.0098 \\
3.32 \%\end{array}$ & $\begin{array}{l}0.0031 \\
0.61 \%\end{array}$ & $\begin{array}{l}-0.0020 \\
-0.40 \%\end{array}$ & $\begin{array}{l}0.0099 \\
3.72 \%\end{array}$ & $\begin{array}{l}0.0199 \\
7.52 \%\end{array}$ \\
\hline Children & $\begin{array}{l}0.0119 \\
2.49 \%\end{array}$ & $\begin{array}{l}0.0056 \\
1.18 \%\end{array}$ & $\begin{array}{l}0.0078 \\
2.66 \%\end{array}$ & $\begin{array}{l}-0.0046 \\
-1.57 \%\end{array}$ & $\begin{array}{l}0.0003 \\
0.06 \%\end{array}$ & $\begin{array}{l}-0.0014 \\
-0.28 \%\end{array}$ & $\begin{array}{l}0.0126 \\
4.77 \%\end{array}$ & $\begin{array}{l}-0.0176 \\
-6.65 \%\end{array}$ \\
\hline Education & $\begin{array}{l}0.0352 \\
7.36 \% \\
\end{array}$ & $\begin{array}{l}-0.0175 \\
-3.66 \% \\
\end{array}$ & $\begin{array}{c}0.0477 \\
16.20 \% \\
\end{array}$ & $\begin{array}{l}-0.0007 \\
-0.25 \% \\
\end{array}$ & $\begin{array}{l}0.0657 \\
13.11 \% \\
\end{array}$ & $\begin{array}{l}0.0166 \\
3.30 \% \\
\end{array}$ & $\begin{array}{l}0.0438 \\
16.54 \% \\
\end{array}$ & $\begin{array}{l}-0.0090 \\
-3.41 \% \\
\end{array}$ \\
\hline Tenure & $\begin{array}{c}0.0555 \\
11.59 \%\end{array}$ & $\begin{array}{l}-0.0653 \\
-13.65 \%\end{array}$ & $\begin{array}{c}0.0501 \\
17.00 \%\end{array}$ & $\begin{array}{l}0.0140 \\
4.76 \%\end{array}$ & $\begin{array}{l}0.0057 \\
1.13 \%\end{array}$ & $\begin{array}{l}-0.0268 \\
-5.34 \%\end{array}$ & $\begin{array}{l}0.0229 \\
8.65 \%\end{array}$ & $\begin{array}{l}-0.0942 \\
-35.56 \%\end{array}$ \\
\hline Occupation & $\begin{array}{l}0.1765 \\
36.89 \% \\
\end{array}$ & $\begin{array}{l}-0.0536 \\
-11.22 \%\end{array}$ & $\begin{array}{r}0.0873 \\
29.63 \% \\
\end{array}$ & $\begin{array}{l}0.0255 \\
8.67 \%\end{array}$ & $\begin{array}{l}0.2749 \\
54.80 \%\end{array}$ & $\begin{array}{l}-0.0353 \\
-7.04 \%\end{array}$ & $\begin{array}{l}0.0075 \\
2.84 \%\end{array}$ & $\begin{array}{l}-0.0268 \\
-10.13 \%\end{array}$ \\
\hline Sector of activity & $\begin{array}{l}0.0820 \\
17.15 \% \\
\end{array}$ & $\begin{array}{l}0.1451 \\
30.34 \% \\
\end{array}$ & $\begin{array}{l}0.0065 \\
2.20 \% \\
\end{array}$ & $\begin{array}{l}-0.0077 \\
-2.62 \% \\
\end{array}$ & $\begin{array}{l}0.0165 \\
3.30 \% \\
\end{array}$ & $\begin{array}{l}-0.0376 \\
-7.50 \% \\
\end{array}$ & $\begin{array}{c}0.1120 \\
42.27 \% \\
\end{array}$ & $\begin{array}{r}-0.0989 \\
-37.36 \% \\
\end{array}$ \\
\hline $\begin{array}{l}\text { Part-time/Full-time } \\
\text { (Perm./Temp.) }\end{array}$ & $\begin{array}{l}-0.0002 \\
-0.04 \%\end{array}$ & $\begin{array}{l}-0.0177 \\
-3.71 \%\end{array}$ & $\begin{array}{l}0.0009 \\
0.30 \%\end{array}$ & $\begin{array}{l}0.0653 \\
22.17 \%\end{array}$ & $\begin{array}{l}-0.0003 \\
-0.07 \%\end{array}$ & $\begin{array}{l}0.0172 \\
3.42 \%\end{array}$ & $\begin{array}{l}-0.0025 \\
-0.94 \%\end{array}$ & 0.0077 \\
\hline Type of contract & $\begin{array}{l}0.0170 \\
3.13 \%\end{array}$ & $\begin{array}{c}-0.0624 \\
-13.04 \%\end{array}$ & $\begin{array}{l}0.0059 \\
1.99 \%\end{array}$ & $\begin{array}{l}-0.0690 \\
-23.43 \%\end{array}$ & $\begin{array}{l}0.0132 \\
2.63 \%\end{array}$ & $\begin{array}{c}-0.1518 \\
-30.26 \%\end{array}$ & $\begin{array}{l}0.0013 \\
0.48 \%\end{array}$ & $\begin{array}{c}0.1076 \\
40.61 \%\end{array}$ \\
\hline Constant & $\begin{array}{l}0.0000 \\
0.00 \%\end{array}$ & $\begin{array}{c}0.8763 \\
183.20 \%\end{array}$ & $\begin{array}{l}0.0000 \\
0.00 \%\end{array}$ & $\begin{array}{c}0.9158 \\
310.98 \%\end{array}$ & $\begin{array}{l}0.0000 \\
0.00 \%\end{array}$ & $\begin{array}{c}-1.6962 \\
-338.14 \%\end{array}$ & $\begin{array}{l}0.0000 \\
0.00 \%\end{array}$ & $\begin{array}{c}-0.4432 \\
-167.32 \%\end{array}$ \\
\hline Total & $\begin{array}{r}0.3948 \\
82.54 \% \\
\end{array}$ & $\begin{array}{c}0.0835 \\
17.46 \% \\
\end{array}$ & $\begin{array}{l}0.2244 \\
76.20 \% \\
\end{array}$ & $\begin{array}{c}0.0701 \\
23.80 \% \\
\end{array}$ & $\begin{array}{c}0.3815 \\
76.05 \% \\
\end{array}$ & $\begin{array}{c}0.1201 \\
23.95 \% \\
\end{array}$ & $\begin{array}{c}0.2286 \\
86.31 \% \\
\end{array}$ & $\begin{array}{c}0.0363 \\
13.69 \% \\
\end{array}$ \\
\hline No. of observations & 381 & & 531 & & 372 & & 459 & \\
\hline
\end{tabular}

\begin{tabular}{|c|c|c|c|c|c|c|c|c|}
\hline & \multicolumn{4}{|c|}{ Italy } & \multicolumn{4}{|c|}{ Netherlands } \\
\hline & \multirow{2}{*}{\multicolumn{2}{|c|}{$\begin{array}{c}\text { Females } \\
\begin{array}{c}\text { Log wage gap between public and private } \\
\text { sectors }=0.2991\end{array}\end{array}$}} & \multirow{2}{*}{\multicolumn{2}{|c|}{$\begin{array}{c}\text { Males } \\
\begin{array}{c}\text { Log wage gap between public and private } \\
\text { sectors }=0.1429\end{array}\end{array}$}} & \multirow{2}{*}{\multicolumn{2}{|c|}{$\begin{array}{c}\text { Females } \\
\text { Log wage gap between public and private } \\
\text { sectors }=0.1368\end{array}$}} & \multirow{2}{*}{\multicolumn{2}{|c|}{\begin{tabular}{|c|} 
Males \\
$\begin{array}{c}\text { Log wage gap between public and private } \\
\text { sectors }=0.1980\end{array}$
\end{tabular}}} \\
\hline & & & & & & & & \\
\hline Variables & $\begin{array}{c}\text { Explained part (gap in } \\
\text { endowments) }\end{array}$ & Unexplained part & $\begin{array}{c}\text { Explained part (gap in } \\
\text { endowments) }\end{array}$ & Unexplained part & $\begin{array}{l}\text { Explained part (gap in } \\
\text { endowments) }\end{array}$ & Unexplained part & $\begin{array}{l}\text { Explained part (gap in } \\
\text { endowments) }\end{array}$ & Unexplained part \\
\hline \multirow[t]{2}{*}{ Age } & 0.0262 & -1.1586 & 0.0288 & -0.2157 & 0.0108 & -1.1473 & 0.0263 & -0.2172 \\
\hline & $8.76 \%$ & $-387.34 \%$ & $20.19 \%$ & $-150.92 \%$ & $7.87 \%$ & $-838.25 \%$ & $13.30 \%$ & $-109.68 \%$ \\
\hline \multirow[t]{2}{*}{ Married } & 0.0026 & 0.0005 & 0.0165 & 0.0045 & 0.0016 & -0.0053 & 0.0010 & -0.0060 \\
\hline & $0.87 \%$ & $0.17 \%$ & $11.55 \%$ & $3.12 \%$ & $1.18 \%$ & $-3.84 \%$ & $0.52 \%$ & $-3.04 \%$ \\
\hline \multirow[t]{2}{*}{ Children } & 0.0018 & -0.0100 & 0.0013 & 0.0033 & -0.0004 & -0.0039 & 0.0025 & 0.0035 \\
\hline & $0.60 \%$ & $-3.34 \%$ & $0.93 \%$ & $2.31 \%$ & $-0.31 \%$ & $-2.85 \%$ & $1.24 \%$ & $1.77 \%$ \\
\hline \multirow[t]{2}{*}{ Education } & 0.0521 & -0.0361 & 0.0471 & -0.0021 & 0.0243 & 0.0074 & 0.0615 & 0.0082 \\
\hline & $17.43 \%$ & $-12.07 \%$ & $32.94 \%$ & $-1.45 \%$ & $17.74 \%$ & $5.44 \%$ & $31.04 \%$ & $4.13 \%$ \\
\hline \multirow[t]{2}{*}{ Tenure } & 0.0045 & 0.0406 & 0.0249 & -0.0094 & 0.0089 & -0.0089 & 0.0079 & -0.0446 \\
\hline & $1.50 \%$ & $13.57 \%$ & $17.43 \%$ & $-6.58 \%$ & $6.53 \%$ & $-6.53 \%$ & $4.00 \%$ & $-22.53 \%$ \\
\hline \multirow[t]{2}{*}{ Occupation } & 0.1244 & -0.1431 & 0.0241 & 0.0328 & 0.0437 & 0.1236 & 0.0871 & -0.0147 \\
\hline & $41.60 \%$ & $-47.85 \%$ & $16.88 \%$ & $22.95 \%$ & $31.94 \%$ & $90.28 \%$ & $43.96 \%$ & $-7.41 \%$ \\
\hline \multirow[t]{2}{*}{ Sector of activity } & 0.0304 & 0.0254 & -0.0108 & -0.0078 & 0.0420 & -0.0492 & -0.0028 & -0.0794 \\
\hline & $10.17 \%$ & $8.49 \%$ & $-7.59 \%$ & $-5.43 \%$ & $30.71 \%$ & $-35.94 \%$ & $-1.42 \%$ & $-40.08 \%$ \\
\hline \multirow[t]{2}{*}{\begin{tabular}{|l} 
Part-time/Full-time \\
\end{tabular}} & -0.0083 & -0.0626 & 0.0006 & -0.1315 & -0.0075 & 0.0016 & -0.0071 & 0.0481 \\
\hline & $-2.78 \%$ & $-20.94 \%$ & $0.40 \%$ & $-92.03 \%$ & $-5.47 \%$ & $1.19 \%$ & $-3.56 \%$ & $24.29 \%$ \\
\hline Type of contract & 0.0038 & -0.0435 & 0.0024 & 0.0128 & 0.0015 & -0.2118 & -0.0185 & -0.0156 \\
\hline (Perm./Temp.) & $1.26 \%$ & $-14.54 \%$ & $1.66 \%$ & $8.99 \%$ & $1.11 \%$ & $-154.74 \%$ & $-9.36 \%$ & $-7.88 \%$ \\
\hline \multirow[t]{2}{*}{ Constant } & 0.0000 & 1.4490 & 0.0000 & 0.3210 & 0.0000 & 1.3056 & 0.0000 & 0.3579 \\
\hline & $0.00 \%$ & $484.42 \%$ & $0.00 \%$ & $224.63 \%$ & $0.00 \%$ & $953.94 \%$ & $0.00 \%$ & $180.73 \%$ \\
\hline \multirow[t]{2}{*}{ Total } & 0.2376 & 0.0615 & 0.1349 & 0.0080 & 0.1250 & 0.0119 & 0.1579 & 0.0402 \\
\hline & $79.43 \%$ & $20.57 \%$ & $94.40 \%$ & $5.60 \%$ & $91.30 \%$ & $8.70 \%$ & $79.72 \%$ & $20.28 \%$ \\
\hline No. of observations & 708 & & 935 & & 829 & & 1101 & \\
\hline
\end{tabular}


Table A1 (cont.)

\begin{tabular}{|c|c|c|c|c|c|c|c|c|}
\hline & \multicolumn{4}{|c|}{ Portugal } & \multicolumn{4}{|c|}{ Spain } \\
\hline & \multicolumn{2}{|c|}{ Females } & \multicolumn{2}{|c|}{ Males } & \multicolumn{2}{|c|}{ Females } & \multicolumn{2}{|c|}{ Males } \\
\hline & \multicolumn{2}{|c|}{$\begin{array}{l}\text { Log wage gap between public and private } \\
\text { sectors }=0.6281\end{array}$} & \multicolumn{2}{|c|}{$\begin{array}{l}\text { Log wage gap between public and private } \\
\text { sectors }=0.3051\end{array}$} & \multicolumn{2}{|c|}{$\begin{array}{l}\text { Log wage gap between public and private } \\
\text { sectors }=0.5011\end{array}$} & \multicolumn{2}{|c|}{$\begin{array}{c}\text { Log wage gap between public and private } \\
\text { sectors }=0.2952\end{array}$} \\
\hline Variables & $\begin{array}{l}\text { Explained part (gap } \\
\text { in endowments) }\end{array}$ & Unexplained part & $\begin{array}{l}\text { Explained part (gap } \\
\text { in endowments) }\end{array}$ & Unexplained part & $\begin{array}{l}\text { Explained part (gap } \\
\text { in endowments) }\end{array}$ & Unexplained part & $\begin{array}{l}\text { Explained part (gap } \\
\text { in endowments) }\end{array}$ & Unexplained part \\
\hline Age & $\begin{array}{l}0.0342 \\
5.45 \%\end{array}$ & $\begin{array}{c}1.1152 \\
177.55 \%\end{array}$ & $\begin{array}{l}0.0295 \\
9.65 \%\end{array}$ & $\begin{array}{c}-0.4361 \\
-142.95 \%\end{array}$ & $\begin{array}{c}0.0515 \\
10.28 \%\end{array}$ & $\begin{array}{l}0.0253 \\
5.04 \%\end{array}$ & $\begin{array}{l}0.0189 \\
6.41 \%\end{array}$ & $\begin{array}{l}-1.3915 \\
-471.41 \%\end{array}$ \\
\hline Married & $\begin{array}{l}0.0069 \\
1.10 \%\end{array}$ & $\begin{array}{l}-0.0096 \\
-1.53 \%\end{array}$ & $\begin{array}{l}0.0175 \\
5.74 \%\end{array}$ & $\begin{array}{l}0.0591 \\
19.38 \%\end{array}$ & $\begin{array}{l}0.0066 \\
1.33 \%\end{array}$ & $\begin{array}{l}-0.0125 \\
-2.50 \%\end{array}$ & $\begin{array}{l}0.0033 \\
1.12 \%\end{array}$ & $\begin{array}{l}0.0028 \\
0.93 \%\end{array}$ \\
\hline Children & $\begin{array}{l}-0.0041 \\
-0.65 \%\end{array}$ & $\begin{array}{l}0.0273 \\
4.35 \%\end{array}$ & $\begin{array}{l}-0.0012 \\
-0.38 \%\end{array}$ & $\begin{array}{r}-0.0420 \\
-13.78 \%\end{array}$ & $\begin{array}{l}0.0111 \\
2.22 \%\end{array}$ & $\begin{array}{l}-0.0007 \\
-0.13 \%\end{array}$ & $\begin{array}{l}-0.0024 \\
-0.82 \%\end{array}$ & $\begin{array}{l}0.0088 \\
2.98 \%\end{array}$ \\
\hline Education & $\begin{array}{c}0.1135 \\
18.07 \%\end{array}$ & $\begin{array}{l}-0.0210 \\
-3.34 \%\end{array}$ & $\begin{array}{l}0.0886 \\
29.04 \%\end{array}$ & $\begin{array}{c}0.0688 \\
22.55 \%\end{array}$ & $\begin{array}{c}0.0945 \\
18.85 \%\end{array}$ & $\begin{array}{l}-0.0336 \\
-6.70 \%\end{array}$ & $\begin{array}{c}0.0604 \\
20.46 \%\end{array}$ & $\begin{array}{l}-0.0070 \\
-2.37 \%\end{array}$ \\
\hline Tenure & $\begin{array}{l}0.0223 \\
3.56 \%\end{array}$ & $\begin{array}{l}0.0130 \\
2.08 \%\end{array}$ & $\begin{array}{l}0.0371 \\
12.15 \%\end{array}$ & $\begin{array}{l}0.0633 \\
20.74 \%\end{array}$ & $\begin{array}{l}0.0281 \\
5.61 \%\end{array}$ & $\begin{array}{c}-0.0981 \\
-19.58 \%\end{array}$ & $\begin{array}{l}0.0210 \\
7.12 \%\end{array}$ & $\begin{array}{l}0.0817 \\
27.67 \%\end{array}$ \\
\hline Occupation & $\begin{array}{l}0.2935 \\
46.73 \%\end{array}$ & $\begin{array}{l}0.4721 \\
75.16 \%\end{array}$ & $\begin{array}{l}0.1225 \\
40.16 \%\end{array}$ & $\begin{array}{l}-0.0327 \\
-10.70 \%\end{array}$ & $\begin{array}{l}0.1759 \\
35.10 \%\end{array}$ & $\begin{array}{l}0.0175 \\
3.49 \%\end{array}$ & $\begin{array}{l}0.1031 \\
34.94 \%\end{array}$ & $\begin{array}{l}0.0162 \\
5.48 \%\end{array}$ \\
\hline Sector of activity & $\begin{array}{l}0.0529 \\
8.42 \%\end{array}$ & $\begin{array}{l}-0.0173 \\
-2.75 \%\end{array}$ & $\begin{array}{l}-0.0301 \\
-9.87 \%\end{array}$ & $\begin{array}{l}-0.0265 \\
-8.68 \%\end{array}$ & $\begin{array}{c}0.0762 \\
15.21 \%\end{array}$ & $\begin{array}{c}0.0759 \\
15.14 \%\end{array}$ & $\begin{array}{l}0.0142 \\
4.82 \%\end{array}$ & $\begin{array}{l}-0.1545 \\
-52.34 \%\end{array}$ \\
\hline Part-time/Full-time & $\begin{array}{l}-0.0002 \\
-0.03 \%\end{array}$ & $\begin{array}{l}-0.1306 \\
-20.80 \%\end{array}$ & $\begin{array}{l}0.0002 \\
0.07 \%\end{array}$ & $\begin{array}{c}0.0906 \\
29.69 \%\end{array}$ & $\begin{array}{l}-0.0045 \\
-0.90 \%\end{array}$ & $\begin{array}{l}0.0461 \\
9.21 \%\end{array}$ & $\begin{array}{l}-0.0005 \\
-0.16 \%\end{array}$ & $\begin{array}{l}0.0092 \\
3.11 \%\end{array}$ \\
\hline $\begin{array}{l}\text { Type of contract } \\
\text { (Perm } / \text { Temp }\end{array}$ & $\begin{array}{l}-0.0086 \\
-1.38 \%\end{array}$ & $\begin{array}{l}0.0219 \\
3.48 \%\end{array}$ & $\begin{array}{l}0.0029 \\
0.96 \%\end{array}$ & $\begin{array}{l}0.1106 \\
36.25 \%\end{array}$ & $\begin{array}{l}0.0036 \\
0.72 \%\end{array}$ & $\begin{array}{l}-0.0137 \\
-274 \%\end{array}$ & $\begin{array}{l}0.0253 \\
8.58 \%\end{array}$ & $\begin{array}{l}0.0032 \\
1.09 \%\end{array}$ \\
\hline Constant & $\begin{array}{l}0.0000 \\
0.00 \%\end{array}$ & $\begin{array}{c}-1.3534 \\
-215.48 \%\end{array}$ & $\begin{array}{l}0.0000 \\
0.00 \%\end{array}$ & $\begin{array}{l}0.1830 \\
59.97 \%\end{array}$ & $\begin{array}{l}0.0000 \\
0.00 \%\end{array}$ & $\begin{array}{c}0.0520 \\
10.37 \%\end{array}$ & $\begin{array}{l}0.0000 \\
0.00 \%\end{array}$ & $\begin{array}{c}1.4829 \\
502.38 \%\end{array}$ \\
\hline Total & $\begin{array}{r}0.5105 \\
81.27 \%\end{array}$ & $\begin{array}{l}0.1176 \\
18.73 \% \\
\end{array}$ & $\begin{array}{c}0.2670 \\
87.53 \%\end{array}$ & $\begin{array}{c}0.0381 \\
12.47 \% \\
\end{array}$ & $\begin{array}{c}0.4430 \\
88.41 \%\end{array}$ & $\begin{array}{c}0.0581 \\
11.59 \%\end{array}$ & $\begin{array}{r}0.2434 \\
82.46 \%\end{array}$ & $\begin{array}{l}0.0518 \\
17.54 \% \\
\end{array}$ \\
\hline No. of observations & 699 & & 873 & & 534 & & 826 & \\
\hline
\end{tabular}

\begin{tabular}{|l|c|c|c|c|}
\hline \multirow{2}{*}{ Variables } & \multicolumn{4}{|c|}{ United Kingdom } \\
\cline { 2 - 5 } & \multicolumn{2}{|c|}{ Females } & \multicolumn{2}{c|}{ Males } \\
\cline { 2 - 5 } & \multicolumn{2}{|c|}{$\begin{array}{c}\text { Log wage gap between public and private } \\
\text { sectors }=0.2172\end{array}$} & $\begin{array}{c}\text { Log wage gap between public and private } \\
\text { sectors = 0.1058 }\end{array}$ \\
\hline Age & $\begin{array}{c}\text { Explained part (gap } \\
\text { in endowments) }\end{array}$ & Unexplained part & $\begin{array}{c}\text { Explained part (gap } \\
\text { in endowments) }\end{array}$ & Unexplained part \\
\hline Married & 0.0192 & -0.0371 & 0.0202 & -0.5770 \\
& $8.86 \%$ & $-17.08 \%$ & $19.11 \%$ & $-545.11 \%$ \\
\hline Children & 0.0002 & 0.0060 & -0.0023 & -0.0213 \\
& $0.07 \%$ & $2.78 \%$ & $-2.20 \%$ & $-20.16 \%$ \\
\hline Education & -0.0038 & 0.0086 & -0.0057 & -0.0006 \\
& $-1.73 \%$ & $3.95 \%$ & $-5.42 \%$ & $-0.59 \%$ \\
\hline Tenure & 0.0249 & -0.0191 & 0.0382 & -0.0117 \\
& $11.46 \%$ & $-8.77 \%$ & $36.06 \%$ & $-11.08 \%$ \\
\hline Occupation & 0.0010 & 0.0253 & 0.0009 & 0.0375 \\
& $0.44 \%$ & $11.67 \%$ & $0.88 \%$ & $35.41 \%$ \\
\hline Sector of activity & 0.1377 & -0.0622 & -0.0006 & 0.0101 \\
& $63.40 \%$ & $-28.62 \%$ & $-0.58 \%$ & $9.53 \%$ \\
\hline Part-time/Full-time & 0.0251 & -0.0381 & 0.0280 & -0.0512 \\
& $11.55 \%$ & $-17.55 \%$ & $26.42 \%$ & $-48.42 \%$ \\
\hline Type of contract & 0.0000 & 0.0000 & 0.0000 & 0.0000 \\
(Perm./Temp.) & $0.00 \%$ & $0.00 \%$ & $0.00 \%$ & $0.00 \%$ \\
\hline Constant & -0.0050 & 0.1661 & 0.0000 & 0.0000 \\
& $-2.28 \%$ & $76.50 \%$ & $0.00 \%$ & $0.00 \%$ \\
\hline Total & 0.0000 & -0.0318 & 0.0000 & 0.6416 \\
& $0.00 \%$ & $-14.65 \%$ & $0.00 \%$ & $606.15 \%$ \\
\hline No. of observations & 0.1993 & 0.0179 & 0.0786 & 0.0272 \\
& $91.77 \%$ & $8.23 \%$ & $74.27 \%$ & $25.73 \%$ \\
\hline & 513 & & 699 & \\
\hline & & & & \\
\hline
\end{tabular}


Table A2. OLS Log-wage underlying regressions for Oaxaca-Blinder wage decomposition

\begin{tabular}{|c|c|c|c|c|c|c|c|c|c|c|c|c|c|c|c|c|c|c|}
\hline & \multicolumn{6}{|c|}{ BELGIUM } & \multicolumn{6}{|c|}{ DENMARK } & \multicolumn{6}{|c|}{ FRANCE } \\
\hline & \multicolumn{3}{|c|}{ Females } & \multicolumn{3}{|c|}{ Males } & \multicolumn{3}{|c|}{ Females } & \multicolumn{3}{|c|}{ Males } & \multicolumn{3}{|c|}{ Females } & \multicolumn{3}{|c|}{ Males } \\
\hline \multirow{2}{*}{\multicolumn{19}{|c|}{ Demographics }} \\
\hline & & & & & & & & & & & & & & & & & & \\
\hline Age & 0.010 & $0.062^{*}$ & $0.042^{*}$ & 0.026 & 0.030 & $0.038^{*}$ & -0.027 & $0.050^{*}$ & -0.007 & -0.097 & $0.101^{* * * *}$ & 0.040 & 0.019 & 0.014 & 0.016 & 0.014 & $0.028^{* *}$ & $0.026^{* * *}$ \\
\hline \multirow{3}{*}{ Age squared } & $(0.044)$ & $(0.035)$ & $(0.024)$ & $(0.060)$ & $(0.025)$ & $(0.021)$ & $(0.021)$ & $(0.027)$ & $(0.020)$ & $(0.105)$ & $(0.038)$ & $(0.035)$ & $(0.029)$ & $(0.020)$ & $(0.017)$ & $(0.033)$ & $(0.014)$ & $(0.013)$ \\
\hline & -0.000 & $-0.001 *$ & -0.000 & -0.000 & -0.000 & -0.000 & 0.000 & -0.000 & 0.000 & 0.001 & $-0.001^{1 * * *}$ & -0.000 & -0.000 & -0.000 & -0.000 & -0.000 & $-0.000^{*}$ & $-0.000^{*}$ \\
\hline & $(0.001)$ & $(0.000)$ & $(0.000)$ & $(0.001)$ & $(0.000)$ & $(0.000)$ & $(0.000)$ & $(0.000)$ & $(0.000)$ & $(0.001)$ & $(0.000)$ & $(0.000)$ & $(0.000)$ & $(0.000)$ & $(0.000)$ & $(0.000)$ & $(0.000)$ & $(0.000)$ \\
\hline \multirow{4}{*}{ Children } & -0.020 & -0.008 & -0.015 & -0.031 & -0.002 & -0.010 & 0.004 & $-0.078^{* *}$ & $-0.051^{-}$ & 0.076 & $0.073 * *$ & $0.082 * *$ & 0.005 & $-0.036^{*}$ & -0.019 & 0.021 & $0.040 * * *$ & $0.039 * * *$ \\
\hline & $(0.032)$ & $(0.022)$ & $(0.018)$ & $(0.033)$ & $(0.025)$ & $(0.021)$ & $(0.034)$ & $(0.033)$ & $(0.026)$ & $(0.131)$ & $(0.033)$ & $(0.032)$ & $(0.027)$ & $(0.019)$ & $(0.016)$ & $(0.027)$ & $(0.015)$ & $(0.013)$ \\
\hline & 0.041 & -0.012 & 0.009 & 0.053 & 0.022 & $0.032^{*}$ & -0.018 & 0.052 & 0.011 & -0.072 & -0.015 & 0.002 & 0.001 & $0.061^{* *}$ & $0.039 * *$ & 0.042 & 0.018 & $0.024 *$ \\
\hline & $(0.028)$ & $(0.023)$ & $(0.017)$ & $(0.035)$ & $(0.022)$ & $(0.019)$ & $(0.030)$ & $(0.035)$ & $(0.029)$ & $(0.096)$ & $(0.049)$ & $(0.033)$ & $(0.028)$ & $(0.025)$ & $(0.019)$ & $(0.026)$ & $(0.016)$ & $(0.014)$ \\
\hline \multicolumn{19}{|l|}{ Education } \\
\hline \multirow{2}{*}{$\begin{array}{l}\text { Recognised third level education } \\
\text { (ISCED 5-7) }\end{array}$} & 0.072 & $0.144^{* * *}$ & $0.118^{* * * *}$ & $0.141 * * *$ & $0.094 * * *$ & $0.119 * * *$ & $0.139 * * *$ & $0.125^{* * *}$ & $0.098 * *$ & $0.294 *$ & 0.021 & 0.082 & $0.103 * *$ & $0.115^{* * *}$ & $0.122 * * *$ & $0.225 * * *$ & $0.178 * * *$ & $0.186^{* * *}$ \\
\hline & $(0.047)$ & $(0.033)$ & $(0.027)$ & $(0.042)$ & $(0.036)$ & $0.028)$ & $0.047)$ & $0.033)$ & $(0.037)$ & $(0.138)$ & $(0.066)$ & $(0.060)$ & $(0.044)$ & $(0.032)$ & $0.025)$ & $(0.070)$ & $(0.030)$ & $(0.028)$ \\
\hline Second stage of secondary level & 0.044 & 0.001 & 0.014 & 0.022 & -0.022 & -0.024 & 0.029 & 0.044 & 0.043 & 0.320 & -0.066 & 0.003 & -0.055 & -0.022 & -0.026 & $-0.105 * *$ & $-0.048 * *$ & $-0.054 * * *$ \\
\hline education (ISCED 3) & $(0.041)$ & $(0.026)$ & $(0.023)$ & $(0.044)$ & $(0.025)$ & $(0.021)$ & $(0.051)$ & $(0.030)$ & $(0.039)$ & $(0.193)$ & $(0.058)$ & $(0.045)$ & $(0.035)$ & $(0.024)$ & $(0.019)$ & $(0.051)$ & $(0.020)$ & $(0.019)$ \\
\hline Occupation & & & & & & & & & & & & & & & & & & \\
\hline Professionals & $\begin{array}{c}0.262^{* * * *} \\
(0.0544\end{array}$ & $\begin{array}{c}0.233^{* * *} * \\
(0.063)\end{array}$ & $\begin{array}{c}0.237^{* * * *} \\
(0.0477\end{array}$ & $\begin{array}{l}0.066 \\
(0.091)\end{array}$ & $\begin{array}{l}0.133 \\
(0.107)\end{array}$ & $\begin{array}{l}0.122^{*} \\
(0.066)\end{array}$ & $\begin{array}{l}0.232 \\
(0.173)\end{array}$ & $\begin{array}{l}0.010 \\
(0.107)\end{array}$ & $\begin{array}{l}0.108^{*} \\
(0.064)\end{array}$ & $\begin{array}{l}-0.028 \\
(0.141)\end{array}$ & $\begin{array}{l}0.102 \\
(0.088)\end{array}$ & $\begin{array}{l}0.092 \\
(0.062)\end{array}$ & $\begin{array}{c}0.438^{* * *} \\
(0.062)\end{array}$ & $\begin{array}{c}0.367^{* * *} \\
(0.0544)\end{array}$ & $\begin{array}{c}\begin{array}{c}0.394 * * * \\
(0.046)\end{array} \\
\end{array}$ & $\begin{array}{l}0.208 \\
(0.138)\end{array}$ & $\begin{array}{c}0.396^{* * * *} \\
(0.053)\end{array}$ & $\begin{array}{c}0.354^{* * *} * \\
(0.054)\end{array}$ \\
\hline Technicians and associate & 0.105 & 0.023 & 0.068 & -0.030 & 0.036 & 0.019 & 0.114 & 0.068 & 0.030 & -0.108 & 0.111 & 0.098 & $0.229 * * *$ & $0.183^{* * * *}$ & $0.204 * * *$ & -0.017 & $0.056 *$ & 0.038 \\
\hline & $(0.064)$ & $(0.063)$ & $(0.049)$ & $(0.054)$ & $(0.045)$ & $(0.033)$ & $0.150)$ & $(0.052)$ & $(0.060)$ & $(0.132)$ & $(0.077)$ & $(0.059)$ & $(0.050)$ & $(0.046)$ & $(0.038)$ & $(0.054)$ & $(0.032)$ & $(0.028)$ \\
\hline Clerks & 0.075 & 0.026 & 0.034 & -0.058 & 0.006 & -0.007 & -0.092 & -0.063 & $-0.157 * * *$ & -0.255 & $-0.108^{*}$ & $-0.225^{*}$ & 0.015 & -0.028 & -0.032 & $-0.124^{*}$ & $-0.140^{* * * *}$ & $-0.123^{* * *}$ \\
\hline & $(0.060)$ & $(0.037)$ & $(0.037)$ & $(0.070)$ & $(0.050)$ & $(0.040)$ & $(0.183)$ & $(0.052)$ & $(0.055)$ & $(0.281)$ & $(0.060)$ & $(0.117)$ & $(0.051)$ & $(0.040)$ & $(0.033)$ & $(0.074)$ & $(0.036)$ & $(0.034)$ \\
\hline Service workers and shop and & $-0.133^{*} *$ & -0.077 & $-0.083 * *$ & 0.048 & $-0.137 * * *$ & $-0.123^{* * * *}$ & 0.071 & -0.004 & 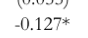 & 0.411 & -0.139 & -0.066 & -0.100 & $-0.190 * * * *$ & $-0.182 * * *$ & 0.012 & $-0.263^{* * * *}$ & $-0.141 * * *$ \\
\hline market sales workers & $(0.062)$ & $(0.050)$ & $(0.041)$ & $(0.093)$ & $(0.052)$ & $(0.045)$ & $(0.155)$ & $(0.061)$ & $(0.067)$ & $(0.392)$ & $(0.144)$ & $(0.110)$ & $(0.072)$ & $(0.045)$ & $(0.041)$ & $(0.055)$ & $(0.060)$ & $(0.048)$ \\
\hline Craft and related trade workers & 0.000 & $-0.231 * *$ & $-0.253 * *$ & $-0.267 * * *$ & $-0.095 * *$ & $-0.091 * *$ & 0.000 & $0.207 * *$ & 0.153 & -0.206 & 0.024 & -0.012 & $-0.241 * * *$ & $-0.282^{* *}$ & $-0.280 * *$ & $-0.188^{* * * *}$ & $-0.134 * * *$ & $-0.160^{* * * *}$ \\
\hline + skilled workers & $(0.000)$ & $(0.102)$ & $(0.098)$ & $(0.073)$ & $(0.047)$ & $(0.038)$ & $(0.000)$ & $(0.099)$ & $(0.105)$ & $(0.328)$ & $(0.090)$ & $(0.073)$ & $(0.060)$ & $(0.131)$ & $(0.123)$ & $(0.063)$ & $(0.029)$ & $(0.027)$ \\
\hline $\begin{array}{l}\text { Plant and machine operators } \\
\text { nas dsempless }\end{array}$ & $-0.582 * * *$ & -0.045 & -0.109 & -0.001 & $-0.144 * * *$ & $-0.122 * * *$ & 0.000 & -0.037 & -0.043 & 0.000 & -0.155 & -0.092 & $-0.589 * * *$ & $-0.240 * * *$ & $-0.260 * * *$ & -0.139 & $-0.110^{* * * *}$ & $-0.142^{* * *}$ \\
\hline & $(0.085)$ & $(0.072)$ & $(0.072)$ & $(0.112)$ & $(0.046)$ & $(0.041)$ & $(0.000)$ & $(0.133)$ & (0.134) & $(0.000)$ & $(0.096)$ & $(0.108)$ & $(0.100)$ & $(0.072)$ & $(0.075)$ & $(0.108)$ & $(0.028)$ & $(0.028)$ \\
\hline Elementary occupations & $-0.233^{* * * *}$ & -0.047 & $-0.128 * * *$ & -0.111 & -0.091 & $-0.093^{*}$ & 0.000 & -0.011 & -0.118 & -0.163 & -0.072 & -0.020 & $-0.298^{* * * *}$ & $-0.213^{* * *}$ & $-0.257 * * *$ & $-0.244 * * *$ & $-0.223^{* * * *}$ & $-0.226 * * *$ \\
\hline & $(0.077)$ & $(0.050)$ & $(0.049)$ & $(0.105)$ & $(0.064)$ & $(0.050)$ & $(0.000)$ & $(0.069)$ & $(0.074)$ & $(0.218)$ & $(0.127)$ & $(0.079)$ & $(0.061)$ & $(0.061)$ & $(0.049)$ & $(0.074)$ & $(0.041)$ & $(0.037)$ \\
\hline Sector of activity & & & & & & & & & & & & & & & & & & \\
\hline Industry $(\mathrm{E}+\mathrm{D}+\mathrm{F})$ & $\begin{array}{l}0.000 \\
0.0000\end{array}$ & $\begin{array}{l}-0.016 \\
(0.039)\end{array}$ & $\begin{array}{l}0.014 \\
0.037\end{array}$ & $\begin{array}{l}0.075 \\
(0.062)\end{array}$ & $\begin{array}{l}0.065 \\
(0.042)\end{array}$ & $\begin{array}{c}0.077^{* * *} \\
0.0288\end{array}$ & $\begin{array}{l}0.000 \\
0.000)\end{array}$ & $\begin{array}{l}-0.001 \\
-0.0544\end{array}$ & $\begin{array}{l}0.065^{*} \\
0.0377\end{array}$ & $\begin{array}{l}0.551 \\
(0.435)\end{array}$ & $\begin{array}{l}0.058 \\
0.0606\end{array}$ & $\begin{array}{l}0.032 \\
(0.049)\end{array}$ & $\begin{array}{l}-0.044 \\
(0.192)\end{array}$ & $\begin{array}{l}0.018 \\
0.038\end{array}$ & $\begin{array}{l}-0.010 \\
0.033\end{array}$ & $\begin{array}{c}0.178^{* *} \\
(0.079)\end{array}$ & $\begin{array}{l}0.051 \\
0.041\end{array}$ & $\begin{array}{l}0.027 \\
(0.021)\end{array}$ \\
\hline Other services $(\mathrm{G}+\mathrm{H}+\mathrm{J}+\mathrm{K})$ & o.048 & $\begin{array}{l}0.0390^{*} \\
0.07\end{array}$ & $\begin{array}{l}(0.037) \\
0.0811^{* *}\end{array}$ & $\begin{array}{l}(0.062) \\
0.109 *\end{array}$ & $\begin{array}{l}(0.042) \\
-0.058\end{array}$ & $\begin{array}{l}(0.028) \\
-0.046\end{array}$ & $\begin{array}{l}(0.0000) \\
0.000\end{array}$ & $\begin{array}{l}(0.024) \\
-0.22+* *+\end{array}$ & $\begin{array}{l}(0.017) \\
-0.106^{*}\end{array}$ & $\begin{array}{l}0.0936 \\
0.096\end{array}$ & $\begin{array}{l}0.0642 \\
0.042\end{array}$ & 0 & 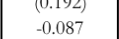 & $\begin{array}{l}0.027 \\
0.027 \\
0\end{array}$ & $\begin{array}{l}-0.0033) \\
-0.007 \\
-\end{array}$ & 0.053 & $\begin{array}{l}0.018 \\
0.018\end{array}$ & $\begin{array}{l}(0.021) \\
-0.021\end{array}$ \\
\hline & $(0.069)$ & $(0.039)$ & $(0.039)$ & $(0.060)$ & $(0.051)$ & $(0.042)$ & $(0.000)$ & $(0.040)$ & $(0.059)$ & $(0.606)$ & $(0.060)$ & $(0.049)$ & $(0.096)$ & $(0.031)$ & $(0.025)$ & $(0.086)$ & $(0.041)$ & $(0.024)$ \\
\hline Transportation (I) & $-0.181 * *$ & -0.067 & $-0.189 * *$ & 0.002 & 0.058 & 0.029 & 0.000 & -0.067 & 0.036 & 0.008 & -0.042 & 0.077 & 0.040 & 0.111 & 0.049 & -0.047 & -0.035 & -0.022 \\
\hline & $(0.090)$ & $(0.094)$ & $(0.090)$ & $(0.072)$ & $(0.060)$ & $(0.040)$ & $(0.000)$ & $(0.061)$ & $(0.053)$ & $(0.271)$ & $(0.085)$ & $(0.081)$ & $(0.080)$ & $(0.069)$ & $(0.047)$ & $(0.088)$ & $(0.053)$ & $(0.041)$ \\
\hline Public administration and & 0.059 & 0.032 & $0.069 *$ & -0.065 & 0.003 & 0.009 & 0.064 & $0.477 * * *$ & 0.069 & -0.445 & -0.004 & -0.083 & -0.003 & -0.040 & -0.020 & -0.027 & 0.079 & $0.098 * * *$ \\
\hline & $(0.053)$ & $(0.057)$ & $(0.039)$ & $(0.054)$ & $(0.120)$ & $(0.042)$ & $(0.049)$ & $(0.111)$ & $(0.051)$ & $(0.281)$ & $(0.060)$ & $(0.070)$ & $(0.063)$ & $(0.054)$ & $(0.036)$ & $(0.049)$ & $(0.131)$ & $(0.035)$ \\
\hline Other iob characteristics & & & & & & & & & & & & & & & & & & \\
\hline Tenure & -0.005 & 0.008 & 0.004 & $0.059 * *$ & 0.015 & $0.023^{*}$ & 0.002 & $0.072 * *$ & $0.062^{* *} * 2>0$ & -0.016 & & 0.056 & $0.044^{* * *}$ & $0.0311^{* *}$ & $0.033^{* * * *}$ & 0.024 & 0.016 & 0.013 \\
\hline & $(0.025)$ & $(0.017)$ & $(0.014)$ & $(0.024)$ & $(0.016)$ & $(0.013)$ & $(0.027)$ & $(0.035)$ & $(0.029)$ & $(0.114)$ & $(0.053)$ & $(0.037)$ & $(0.022)$ & $(0.015)$ & $(0.012)$ & $(0.020)$ & $(0.011)$ & (0.010) \\
\hline Tenure squared & 0.0 & 0.00 & 0.000 & $-0.004 * *$ & 0.00 & -0.001 & 0.003 & $-0.009 *$ & -0.005 & 0.00 & -0.006 & -0.00 & $-0.003^{*}$ & -0.001 & $-0.002 * *$ & -0.001 & -0.001 & -0.000 \\
\hline & & $(0.001)$ & $(0.001)$ & $(0.002)$ & & $(0.001)$ & $(0.003)$ & $(0.005)$ & $(0.003)$ & $(0.01$ & $(0.005)$ & $(0.00$ & $(0.002)$ & $(0.001)$ & $(0.001)$ & $(0.001)$ & $(0.00$ & $(0.0$ \\
\hline Full time contract & $\begin{array}{l}-0.006 \\
-0.06\end{array}$ & 0.016 & 0.008 & $\begin{array}{l}-0.183 \\
-0.18\end{array}$ & $0.203 * * *$ & -0.122 & 0.031 & $\begin{array}{l}-0.064 \\
-0.04 \\
\end{array}$ & 0.013 & 0.00 & 0.00 & 0.00 & -0.0 & $-0.034^{*}$ & -0.0 & 0.0 & $\begin{array}{lll}-0.05 & \\
-0.05 & \end{array}$ & -0.0 \\
\hline & $(0.0)$ & $(0.022)$ & $(0.016)$ & $(0.143)$ & 54) & $(0.143)$ & $(0.058)$ & $(0.046)$ & $(0.055)$ & $(0.000)$ & $(0.000)$ & $(0.000)$ & $(0.034)$ & $(0.020)$ & $(0.017)$ & $(0.081)$ & $(0.108)$ & $(0.083)$ \\
\hline Permanent contract & & & 0.030 & 0.0 & & & $-0.149 * * *$ & 0.000 & $-0.156 * * * *$ & 0.000 & -0.028 & -0.010 & $0.065 * *$ & 0.020 & $0.043^{*}$ & -0.072 & 0.039 & 0.003 \\
\hline & $(0.036)$ & $(0.035)$ & $(0.023)$ & $(0.045)$ & $(0.050)$ & $(0.032)$ & $(0.034)$ & $(0.000)$ & $(0.023)$ & $(0.000)$ & $(0.138)$ & $(0.121)$ & $(0.030)$ & $(0.050)$ & $(0.024)$ & $(0.051)$ & $(0.071)$ & $(0.048)$ \\
\hline Constant & $5.189 * * *$ & $4.263 * * *$ & $4.602 * * *$ & $5.106 * * *$ & 4.792**** & $4.929 * * *$ & $4.730 * * *$ & $3.415 * * *$ & $4.507 * * *$ & $6.588 * * *$ & $2.552^{2 * * *}$ & $3.646 * * *$ & $3.093 * * *$ & $3.258 * * *$ & $3.190 * * *$ & $3.626 * * *$ & $3.163^{* * *}$ & $3.268 * * *$ \\
\hline & $(0.756)$ & $(0.664)$ & $(0.441)$ & (1.105) & $(0.474)$ & $(0.416)$ & $(0.428)$ & $(0.517)$ & $(0.385)$ & (1.991) & $(0.738)$ & $(0.649)$ & $(0.560)$ & $(0.366)$ & $(0.313)$ & $(0.610)$ & $(0.278)$ & $(0.241)$ \\
\hline$\overline{\text { Observations }}$ & 173 & 243 & 419 & 132 & 321 & 463 & 42 & 47 & 89 & 29 & 74 & 103 & 333 & 561 & 894 & 228 & 823 & 1,051 \\
\hline R-squared & 0.456 & 0.417 & 0.411 & 0.456 & 0.330 & 0.333 & 0.769 & 0.824 & 0.584 & 0.791 & 0.434 & 0.400 & 0.418 & 0.370 & 0.383 & 0.448 & 0.442 & 0.431 \\
\hline
\end{tabular}

1. Robust weighted standard errors in parenthesis

2. Base categories for dummy variables: Education: less than 2nd stage of secondary education, Legishators, senior officials and managers, Educ. and Health\&Social Work, Part time contract, Temporary contract

3. Estimations are run for 1997 
Table A2 (cont.)

\begin{tabular}{|c|c|c|c|c|c|c|c|c|c|c|c|c|c|c|c|c|c|c|}
\hline & \multicolumn{6}{|c|}{ GERMANY } & \multicolumn{6}{|c|}{ GREECE } & \multicolumn{6}{|c|}{ IRELAND } \\
\hline & \multicolumn{3}{|c|}{ 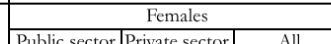 } & \multicolumn{3}{|c|}{$\begin{array}{c} \\
\text { Males } \\
\end{array}$} & \multicolumn{3}{|c|}{ Females } & \multicolumn{3}{|c|}{ Males } & \multicolumn{3}{|c|}{ Females } & \multicolumn{3}{|c|}{ Males } \\
\hline \multirow{2}{*}{\multicolumn{19}{|c|}{$\begin{array}{l}\text { Demographics } \\
\end{array}$}} \\
\hline & & & & & & & & & & & & & & & & & & \\
\hline & $(0.018)$ & $(0.021)$ & $(0.016)$ & $(0.042)$ & $(0.015)$ & $(0.016)$ & $(0.039)$ & $(0.025)$ & $(0.020)$ & $(0.036)$ & $(0.023)$ & $(0.020)$ & $(0.043)$ & $(0.025)$ & $(0.022)$ & $(0.026)$ & $(0.019)$ & $(0.015)$ \\
\hline \multirow[t]{2}{*}{ Age squared } & -0.000 & $-0.001 * * *$ & $-0.001 * * *$ & 0.000 & -0.000 & -0.000 & -0.000 & -0.000 & $-0.000 * *$ & 0.000 & -0.000 & -0.000 & -0.001 & 0.000 & -0.000 & -0.001 ** & -0.000 & $-0.000 * *$ \\
\hline & $(0.000)$ & $(0.000)$ & $(0.000)$ & $(0.001)$ & $(0.000)$ & $(0.000)$ & $(0.000)$ & $(0.000)$ & $(0.000)$ & $(0.000)$ & $(0.000)$ & $(0.000)$ & $(0.001)$ & $(0.000)$ & $(0.000)$ & $(0.000)$ & $(0.000)$ & $(0.000)$ \\
\hline \multirow[t]{4}{*}{ Married } & 0.021 & -0.019 & $\begin{array}{r}-0.005 \\
-0.021\end{array}$ & 0.009 & 0.010 & 0.012 & -0.012 & 0.020 & 0.002 & 0.037 & 0.015 & 0.020 & 0.035 & $0.052^{*}$ & 0.038 & $0.068 * *$ & 0.012 & 0.037 \\
\hline & $(0.023)$ & $(0.030)$ & $(0.021)$ & $(0.041)$ & $(0.022)$ & $(0.019)$ & $(0.028)$ & $(0.030)$ & $(0.023)$ & $(0.037)$ & $(0.030)$ & $(0.025)$ & $(0.040)$ & $(0.029)$ & $(0.025)$ & $(0.032)$ & $(0.030)$ & $(0.025)$ \\
\hline & $-0.048^{*}$ & $-0.085 * *$ & $-0.070 * *$ & 0.028 & 0.035* & $0.037^{*}$ & 0.047 & 0.015 & 0.040 & 0.047 & $0.064 * *$ & $0.064 * * *$ & -0.024 & 0.035 & 0.023 & -0.012 & $0.098 * * *$ & 0.059 ** \\
\hline & $(0.026)$ & $(0.040)$ & $(0.028)$ & $(0.044)$ & $(0.020)$ & $(0.020)$ & $(0.029)$ & $(0.033)$ & $(0.027)$ & $(0.035)$ & $(0.029)$ & $(0.023)$ & $(0.043)$ & $(0.028)$ & $(0.026)$ & $(0.033)$ & $(0.028)$ & $(0.024)$ \\
\hline \multicolumn{19}{|l|}{ Education } \\
\hline \multirow{2}{*}{$\begin{array}{l}\text { Recognised third level education } \\
\text { (ISCED 5-7) }\end{array}$} & 0.030 & 0.075 & 0.052 & -0.123 & $0.088 * * *$ & 0.034 & 0.037 & $0.087 * *$ & $0.076 * * *$ & $0.124 * * *$ & $0.170^{* * * *}$ & $0.144 * * *$ & $0.219 * * *$ & 0.065 & $0.142 * * *$ & 0.069 & $0.177^{* * * *}$ & $0.157 * * *$ \\
\hline & $(0.032)$ & $(0.058)$ & $(0.032)$ & $(0.090)$ & $(0.031)$ & $(0.041)$ & $(0.038)$ & $(0.038)$ & $(0.029)$ & $(0.046)$ & $(0.045)$ & $(0.033)$ & $(0.063)$ & $(0.049)$ & $(0.038)$ & $(0.062)$ & $(0.055)$ & $(0.040)$ \\
\hline & -0.034 & -0.066 & $-0.044^{*}$ & 0.019 & $-0.054 * * *$ & -0.031 & -0.005 & 0.033 & 0.013 & -0.006 & $-0.058^{*}$ & -0.024 & 0.014 & 0.024 & 0.001 & -0.028 & -0.035 & -0.022 \\
\hline education (ISCED 3) & $(0.026)$ & $(0.041)$ & $(0.026)$ & $(0.074)$ & $(0.020)$ & $(0.024)$ & $(0.032)$ & $(0.035)$ & $(0.027)$ & $(0.038)$ & $(0.030)$ & $(0.024)$ & $(0.050)$ & $(0.031)$ & $(0.028)$ & $(0.044)$ & $(0.032)$ & $(0.025)$ \\
\hline Occupation & & & & & & & & & & & & & & & & & & \\
\hline Professionals & $\begin{array}{c}0.293^{* * *} * \\
(0.046)\end{array}$ & $\begin{array}{c}0.249 * * * \\
(0.072)\end{array}$ & $\begin{array}{c}0.319 * * * \\
(0.042)\end{array}$ & $\begin{array}{c}0.416^{* * * *} \\
(0.125)\end{array}$ & $\begin{array}{c}0.266^{* * * *} \\
(0.049)\end{array}$ & $\begin{array}{l}0.300^{* * * *} \\
(0.051)\end{array}$ & $\begin{array}{l}0.395^{* * * *} \\
(0.050)\end{array}$ & $\begin{array}{c}0.289 * * * * \\
(0.086)\end{array}$ & $\begin{array}{c}0.422^{* * * *} \\
(0.060)\end{array}$ & $\begin{array}{c}0.211^{* * * *} \\
(0.076)\end{array}$ & $\begin{array}{c}0.211^{* * * *} \\
(0.079)\end{array}$ & $\begin{array}{c}0.255^{* * * *} \\
(0.057)\end{array}$ & $\begin{array}{c}0.444 * * * \\
(0.083)\end{array}$ & $\begin{array}{c}0.3577 * * \\
(0.092)\end{array}$ & $\begin{array}{l}0.515^{* * * *} \\
(0.062)\end{array}$ & $\begin{array}{c}0.249 * * * \\
(0.079)\end{array}$ & $\begin{array}{c}0.300^{4 * * *} \\
(0.083)\end{array}$ & $\begin{array}{l}0.274 * * * \\
(0.057)\end{array}$ \\
\hline $\begin{array}{l}\text { Technicians and associate } \\
\text { professionals }\end{array}$ & 0.042 & 0.073 & $0.067^{*}$ & 0.083 & 0.058 & $0.077^{* *}$ & $-0.122 * * *$ & 0.095 & 0.024 & $-0.156^{* *}$ & 0.188 & 0.028 & $0.274 * * *$ & $0.275^{* * *}$ & $0.257 * * *$ & -0.002 & $0.181 * * *$ & $0.132^{* * *}$ \\
\hline & $(0.031)$ & $(0.050)$ & $(0.034)$ & $(0.101)$ & $(0.043)$ & $(0.038)$ & $(0.042)$ & $(0.070)$ & $(0.049)$ & $(0.069)$ & $(0.115)$ & (0.088) & $(0.100)$ & $(0.056)$ & $(0.048)$ & $(0.058)$ & $(0.070)$ & $(0.051)$ \\
\hline Clerks & $-0.114 * * *$ & 0.074 & 0.030 & -0.079 & 0.040 & 0.028 & -0.070 & -0.003 & 0.020 & 0.019 & 0.027 & 0.037 & 0.061 & $0.106 * *$ & $0.092 * *$ & -0.060 & -0.048 & -0.018 \\
\hline & $(0.040)$ & $(0.085)$ & $(0.070)$ & $(0.125)$ & $(0.050)$ & $(0.048)$ & $(0.044)$ & $(0.048)$ & $(0.037)$ & $(0.047)$ & $(0.067)$ & $(0.041)$ & $(0.056)$ & $(0.050)$ & $(0.040)$ & $(0.063)$ & $(0.072)$ & $(0.048)$ \\
\hline Service workers and shop and & $-0.142 * * *$ & $-0.209 * *$ & $-0.187 * * *$ & $-0.171 * *$ & $-0.164 * * *$ & $-0.151 * * *$ & -0.045 & $-0.169 * *$ & $-0.175^{* *}$ & 0.093 & -0.047 & -0.001 & -0.119 & $-0.226 * * *$ & $-0.195 * * *$ & 0.117 & $-0.159 * *$ & -0.047 \\
\hline market sales workers & $(0.053)$ & $(0.082)$ & $(0.062)$ & $(0.077)$ & $(0.061)$ & $(0.042)$ & $(0.070)$ & $(0.075)$ & $(0.072)$ & $(0.063)$ & $(0.065)$ & $(0.045)$ & $(0.072)$ & $(0.057)$ & $(0.046)$ & $(0.083)$ & $(0.068)$ & $(0.060)$ \\
\hline Craft and related trade workers & 0.020 & $-0.143 *$ & $-0.144 * *$ & $-0.344 *$ & $-0.151 * * *$ & $-0.191 * * *$ & 0.000 & $-0.147 * *$ & $-0.160 * * *$ & $-0.203 * *$ & $-0.181 * * *$ & $-0.175 * * *$ & 0.000 & -0.186 & $-0.248^{* * *}$ & 0.017 & -0.004 & -0.023 \\
\hline + skilled workers & $(0.060)$ & $(0.065)$ & $(0.062)$ & $(0.180)$ & $(0.028)$ & $(0.038)$ & $(0.000)$ & $(0.062)$ & $(0.063)$ & $(0.080)$ & $(0.060)$ & $(0.045)$ & $(0.000)$ & $(0.128)$ & $(0.063)$ & $(0.092)$ & $(0.047)$ & $(0.042)$ \\
\hline $\begin{array}{l}\text { Plant and machine operators } \\
\text { and assemblers }\end{array}$ & $-0.327 * * *$ & -0.111 & $-0.169 * *$ & -0.181 & $-0.142 * * *$ & $-0.159 * * *$ & 0.000 & -0.126 & $-0.137 *$ & 0.100 & $-0.171 * *$ & $-0.086^{*}$ & 0.000 & $-0.272 * * *$ & $-0.272 * * *$ & $-0.261 * * *$ & -0.032 & $-0.102^{* * *}$ \\
\hline & $(0.050)$ & $(0.090)$ & $(0.072)$ & $(0.214)$ & $(0.035)$ & $(0.041)$ & $(0.000)$ & $(0.080)$ & $(0.074)$ & $(0.062)$ & $(0.069)$ & $(0.048)$ & $(0.000)$ & $(0.063)$ & $(0.063)$ & $(0.081)$ & $(0.047)$ & $(0.039)$ \\
\hline Elementary occupations & $-0.393 * * *$ & $-0.174 * * *$ & $-0.224 * * *$ & $-0.293 * * *$ & $-0.225 * * *$ & $-0.255 * * *$ & $-0.227 * * *$ & $-0.184 * * *$ & $-0.182 * * *$ & $-0.109^{*}$ & $-0.159 * *$ & $-0.134 * * *$ & $-0.319^{*}$ & $-0.260 * *$ & $-0.237 * *$ & $-0.335 * * *$ & $-0.414 * * *$ & $-0.378 * * *$ \\
\hline & $(0.089)$ & $(0.057)$ & $(0.051)$ & $(0.106)$ & $(0.043)$ & $(0.039)$ & $(0.063)$ & $(0.050)$ & $(0.041)$ & $(0.063)$ & $(0.065)$ & $(0.044)$ & $(0.163)$ & $(0.107)$ & $(0.095)$ & $(0.072)$ & $(0.093)$ & $(0.061)$ \\
\hline Sector of activity & & & & & & & & & & & & & & & & & & \\
\hline Industry $(\mathrm{E}+\mathrm{D}+\mathrm{F})$ & $\begin{array}{l}0.090 \\
0.103)\end{array}$ & $\begin{array}{l}0.110 \\
0.089)\end{array}$ & $\begin{array}{l}0.077 \\
(0.071)\end{array}$ & $\begin{array}{l}-0.032 \\
(0.131)\end{array}$ & $\begin{array}{l}0.045 \\
(0.052)\end{array}$ & $\begin{array}{c}0.107 * * * \\
(0.029)\end{array}$ & $-1.003^{* * *}$ & 0.052 & $\begin{array}{l}-0.062 \\
60.52\end{array}$ & 0.037 & 0.067 & $0.060^{*}$ & 0.103 & $\begin{array}{ll}0.073 \\
0.0513\end{array}$ & 0.063 & $\begin{array}{l}-0.096 \\
0.005)\end{array}$ & 0.068 & 0.000 \\
\hline Other services $(\mathrm{G}+\mathrm{H}+\mathrm{J}+\mathrm{K})$ & $\begin{array}{l}(0.103) \\
0.014\end{array}$ & (0.0031) & $-0.073^{*}$ & 0.013 & (0.0.082) & $(0.029)$ & 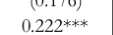 & (0.0027 & (0.0.018 & $\left(\begin{array}{l}0.067) \\
-0.019\end{array}\right.$ & $\begin{array}{c}(0.041) \\
-0.144^{*+*+}\end{array}$ & $\begin{array}{c}(0.033) \\
-0.133^{*+*}\end{array}$ & $(0.154)$ & $(0.051)$ & $(0.044)$ & $(0.095)$ & $(0.044)$ & $(0.033)$ \\
\hline 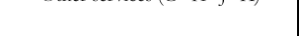 & $(0.058)$ & $(0.070)$ & $(0.042)$ & $(0.060)$ & (0.056) & $(0.034)$ & $(0.073)$ & $(0.047)$ & $(0.035)$ & $(0.090)$ & $(0.047)$ & $(0.035)$ & $(0.070)$ & $(0.044)$ & $(0.038)$ & $(0.072)$ & $\begin{array}{l}-0.060 \\
(0.044)\end{array}$ & $\begin{array}{l}-0.162^{2+4 \pi} \\
(0.034)\end{array}$ \\
\hline Transportation (I) & 0.001 & -0.159 & -0.085 & 0.029 & -0.059 & 0.015 & $0.200^{* * * *}$ & -0.083 & -0.083 & 0.019 & 0.142 & 0.090 & 0.138 & -0.128 & -0.042 & -0.045 & -0.091 & -0.028 \\
\hline & $(0.056)$ & $(0.193)$ & $(0.123)$ & $(0.121)$ & $(0.097)$ & $(0.068)$ & $(0.072)$ & $(0.101)$ & $(0.059)$ & $(0.058)$ & $(0.094)$ & $(0.056)$ & $(0.088)$ & $(0.127)$ & $(0.075)$ & $(0.054)$ & $(0.073)$ & $(0.046)$ \\
\hline $\begin{array}{l}\text { Public administration and } \\
\text { defense }(1) \text { ) }\end{array}$ & $-0.080 * *$ & & 0.016 & -0.033 & 0.228 & -0.045 & $0.266^{* * * *}$ & -0.063 & $0.076^{*}$ & $-0.115^{* * *}$ & $0.184^{* *}$ & -0.024 & -0.108 & $0.200 * * *$ & 0.023 & 0.009 & 0.000 & $0.110 * * *$ \\
\hline & $(0.039)$ & & $(0.044)$ & $(0.072)$ & $(0.160)$ & $(0.043)$ & $(0.057)$ & $(0.090)$ & $(0.044)$ & $(0.042)$ & $(0.089)$ & $(0.035)$ & $(0.069)$ & $(0.049)$ & $(0.041)$ & $(0.055)$ & $(0.000)$ & $(0.042)$ \\
\hline Other job characteristics & & & & & & & & & & & & & & & & & & \\
\hline Tenure & $0.045^{* * *}$ & 0.026 & 0.024 & 0.047 & $0.022^{*}$ & $0.030^{*}$ & 0.020 & $0.061 * * *$ & $0.051^{* * * *}$ & 0.004 & -0.004 & 0.005 & 0.022 & 0.008 & $\begin{array}{ll}0.017 \\
\end{array}$ & -0.038 & 0.021 & 0.003 \\
\hline & $(0.016)$ & $(0.023)$ & $(0.016)$ & (0.041) & $(0.013)$ & (0.016) & $(0.025)$ & $(0.020)$ & & $(0.020)$ & $(0.018)$ & $(0.015)$ & $(0.025)$ & $(0.016)$ & $(0.015)$ & $(0.028)$ & $(0.018)$ & $(0.015)$ \\
\hline Tenure squared & & -0.001 & -0.001 & -0.004 & 0.000 & -0.001 & -0.000 & $-0.004 * *$ & $-0.003 * *$ & 0.001 & 0.002 & 0.001 & -0.002 & 0.001 & -0.000 & $0.004^{*}$ & -0.001 & 0.001 \\
\hline & $(0.001)$ & $(0.002)$ & $(0.001)$ & $(0.004)$ & $(0.001)$ & $(0.002)$ & $(0.002)$ & $(0.002)$ & $(0.001)$ & $(0.002)$ & $(0.00$ & $(0.001)$ & $(0.002)$ & $(0.001)$ & $(0.001)$ & $(0.002)$ & $(0.002)$ & $(0.001)$ \\
\hline Full time contract & $-0.080 * * *$ & -0.064 & $-0.059 * *$ & 0.027 & & -0.006 & -0.003 & 0.017 & 0.012 & -0.022 & -0.08 & -0.047 & 0.060 & 0.032 & 0.037 & $0.164^{*}$ & 0.156 & $0.139 *$ \\
\hline & $(0.027)$ & (0.045) & $(0.029)$ & $(0.074)$ & & $(0.028)$ & (0.083) & $(0.061)$ & (0.053) & $(0.124)$ & $(0.120)$ & (0.093) & $(0.050)$ & $(0.035)$ & $(0.029)$ & $(0.085)$ & $(0.100)$ & $(0.073)$ \\
\hline Permanent contract & -0.029 & $0.267^{*}$ & & -0.059 & 0.031 & -0.009 & -0.026 & 0.039 & 0.054 & -0.065 & 0.006 & 0.014 & -0.021 & $0.149 * * *$ & $0.150 * * *$ & 0.058 & -0.061 & -0.025 \\
\hline & $(0.034)$ & $(0.143)$ & & 74) & $(0.063)$ & $(0.048)$ & & $(0.039)$ & $(0.035)$ & $(0.060)$ & $(0.025)$ & $(0.0$ & $(0.091)$ & $(0.043)$ & $(0.041)$ & $(0.094)$ & $(0.0$ & $(0.038)$ \\
\hline Constant & $2.416^{* * * *}$ & $1.178 * *$ & $1.603 * * *$ & $3.254 * * *$ & $2.462 * * *$ & $2.579 * * *$ & $6.984 * * *$ & $6.107 * * *$ & $6.002 * * *$ & $7.704 * * *$ & $6.788 * * *$ & $6.704 * * *$ & 0.042 & $1.738^{* * *}$ & $1.118 * * *$ & 0.525 & $0.968 * *$ & $0.865 * * *$ \\
\hline & $(0.351)$ & $(0.474)$ & $(0.335)$ & $(0.819)$ & $(0.315)$ & $(0.305)$ & $(0.721)$ & $(0.473)$ & $(0.364)$ & $(0.675)$ & $(0.443)$ & $(0.378)$ & $(0.783)$ & $(0.450)$ & $(0.408)$ & $(0.521)$ & $(0.384)$ & $(0.313)$ \\
\hline Observations & 394 & 597 & 992 & 269 & 1,047 & 1,316 & 180 & 201 & 381 & 228 & 303 & 531 & 133 & 239 & 372 & 122 & 337 & 459 \\
\hline R-squared & 0.378 & 0.224 & 0.244 & 0.331 & 0.376 & 0.310 & 0.566 & 0.440 & 0.596 & 0.445 & 0.397 & 0.423 & 0.627 & 0.510 & 0.600 & 0.629 & 0.427 & 0.480 \\
\hline
\end{tabular}

1. Robust weighted standard errors in parenthesi

2. Base categories for dummy variables: Education: less than 2nd stage of secondary education, Legishators, senior officials and managers, Educ. and Health\&Social Work, Part time contract, Temporary contract

3. Estimations are run for 1997 
Table A2 (cont.)

\begin{tabular}{|c|c|c|c|c|c|c|c|c|c|c|c|c|c|c|c|c|c|c|}
\hline & \multicolumn{6}{|c|}{ ITALY } & \multicolumn{6}{|c|}{ NETHERLANDS } & \multicolumn{6}{|c|}{ PORTUGAL } \\
\hline & \multicolumn{3}{|c|}{\begin{tabular}{|c|} 
Females \\
Public cector| Private sectret
\end{tabular}} & \multicolumn{3}{|c|}{ Males } & \multicolumn{3}{|c|}{$\begin{array}{c}\text { Females } \\
\end{array}$} & \multicolumn{3}{|c|}{$\begin{array}{r}\text { Males } \\
\end{array}$} & \multicolumn{3}{|c|}{ Females } & \multicolumn{3}{|c|}{ Males } \\
\hline \multirow{2}{*}{\multicolumn{19}{|c|}{$\begin{array}{l}\text { Demographics } \\
\end{array}$}} \\
\hline & & $0.045 * * *$ & & & & & & & & & & & & & & & & \\
\hline & $(0.019)$ & $(0.014)$ & $(0.011)$ & (0.024) & (0.014) & $(0.011)$ & $(0.047)$ & $(0.015)$ & $\begin{array}{l}0.027 \\
(0.021)\end{array}$ & (0.028) & (0.015) & $(0.014)$ & $(0.036)$ & $(0.012)$ & $(0.012)$ & $\begin{array}{l}0.020 \\
(0.027)\end{array}$ & $\begin{array}{l}0.03519 \\
(0.018)\end{array}$ & (0.015) \\
\hline \multirow[t]{2}{*}{ Age squared } & 0.000 & $-0.001 * * *$ & $-0.000 * * *$ & -0.000 & -0.000 & -0.000 & 0.000 & $-0.001 * * *$ & -0.000 & 0.000 & -0.000 & -0.000 & $-0.001 * * *$ & $-0.000^{* * * *}$ & $-0.001 * * *$ & -0.000 & $-0.000^{*}$ & $-0.000 * *$ \\
\hline & $(0.000)$ & $(0.000)$ & $(0.000)$ & $(0.000)$ & $(0.000)$ & $(0.000)$ & $(0.001)$ & $(0.000)$ & $(0.000)$ & $(0.000)$ & $(0.000)$ & $(0.000)$ & $(0.000)$ & $(0.000)$ & $(0.000)$ & $(0.000)$ & $(0.000)$ & $(0.000)$ \\
\hline \multirow[t]{4}{*}{ Married } & 0.013 & 0.010 & 0.014 & 0.046 & $0.033^{*}$ & $0.042 * *$ & -0.001 & 0.021 & 0.018 & 0.002 & 0.018 & 0.018 & 0.018 & $0.040^{* *}$ & 0.029 & $0.139 * * * *$ & 0.047 & $0.058 * *$ \\
\hline & $(0.017)$ & $(0.019)$ & $(0.014)$ & $(0.037)$ & $(0.019)$ & $(0.017)$ & $(0.029)$ & $(0.019)$ & $(0.018)$ & $(0.027)$ & $(0.018)$ & $(0.015)$ & $(0.046)$ & $(0.020)$ & $(0.019)$ & $(0.053)$ & $(0.029)$ & $(0.026)$ \\
\hline & -0.021 & 0.007 & 0.004 & 0.012 & 0.001 & 0.003 & 0.034 & -0.020 & -0.007 & $0.054^{* *}$ & $0.029 *$ & $0.035 * *$ & 0.019 & -0.041 & -0.018 & $-0.084 * *$ & 0.004 & -0.004 \\
\hline & $(0.019)$ & $(0.020)$ & $(0.014)$ & $(0.028)$ & $(0.019)$ & $(0.016)$ & $(0.027)$ & $(0.020)$ & $(0.016)$ & $(0.025)$ & $(0.017)$ & $(0.015)$ & $(0.066)$ & $(0.027)$ & $(0.025)$ & $(0.038)$ & $(0.032)$ & $(0.027)$ \\
\hline \multicolumn{19}{|l|}{\begin{tabular}{|l|l} 
Education \\
\end{tabular}} \\
\hline \multirow{2}{*}{$\begin{array}{l}\text { Recognised third level education } \\
\text { (ISCED 5-7) }\end{array}$} & $0.221 * * *$ & 0.063 & $0.171 * * *$ & $0.177 * * *$ & $0.175 * * *$ & $0.169 * * *$ & $0.064 * *$ & $0.117^{* * *}$ & $0.095 * * *$ & $0.102^{* * *}$ & $0.136^{* * *}$ & $0.131^{* * *}$ & $0.201 * *$ & $0.222 * *$ & $0.235^{* * *}$ & 0.200 & $0.320 * * *$ & $0.306 * * *$ \\
\hline & $(0.035)$ & $(0.052)$ & $(0.030)$ & $(0.051)$ & $(0.042)$ & $(0.034)$ & $(0.025)$ & $(0.026)$ & $(0.019)$ & $(0.035)$ & $(0.024)$ & $(0.020)$ & $(0.082)$ & $(0.089)$ & $(0.063)$ & $(0.179)$ & $(0.083)$ & $(0.075)$ \\
\hline Second stage of secondary level & $-0.047 * *$ & -0.025 & $-0.055^{* * * *}$ & $-0.073^{* *}$ & $-0.060 * * *$ & $-0.052^{2 * * *}$ & 0.037 & -0.006 & 0.006 & 0.010 & $-0.050^{* * * *}$ & $-0.037 * *$ & -0.052 & -0.088 & & & -0.067 & -0.068 \\
\hline education (ISCF & $(0.023)$ & $(0.028)$ & $(0.018)$ & $(0.030)$ & $(0.023)$ & $(0.019)$ & $(0.033)$ & $(0.021)$ & $(0.016)$ & $(0.034)$ & $(0.017)$ & $(0.014)$ & $(0.042)$ & $(0.058)$ & $(0.039)$ & $(0.108)$ & $(0.067)$ & $(0.055)$ \\
\hline Occupation & & & & & & & & & & & & & & & & & & \\
\hline Professionals & $\begin{array}{l}0.054 \\
(0.051)\end{array}$ & $\begin{array}{l}0.079 \\
(0.090)\end{array}$ & $\begin{array}{l}0.206 * * * \\
(0.043)\end{array}$ & $\begin{array}{l}0.010 \\
(0.100)\end{array}$ & $\begin{array}{l}0.097 * \\
(0.050)\end{array}$ & $\begin{array}{l}0.040 \\
(0.066)\end{array}$ & $\begin{array}{l}0.198 * * * \\
(0.041)\end{array}$ & $\begin{array}{l}0.177^{* *} \\
(0.073)\end{array}$ & $\begin{array}{l}0.121 * * * * \\
(0.041)\end{array}$ & $\begin{array}{l}0.158 * * * \\
(0.044)\end{array}$ & $\begin{array}{l}0.191 * * * * \\
(0.032)\end{array}$ & $\begin{array}{l}0.187 * * * * \\
(0.027)\end{array}$ & $\begin{array}{l}0.946 * * * \\
(0.180)\end{array}$ & $\begin{array}{l}0.792^{* * * 4} \\
(0.103)\end{array}$ & $\begin{array}{l}0.660^{* * * *} \\
(0.090)\end{array}$ & $\begin{array}{l}0.643 * * * \\
(0.223)\end{array}$ & $\begin{array}{l}0.440^{* * * *} \\
(0.111)\end{array}$ & $\begin{array}{l}0.484 * * * \\
(0.097)\end{array}$ \\
\hline $\begin{array}{l}\text { Technicians and associate } \\
\text { nafescionll. }\end{array}$ & -0.039 & $0.115 * *$ & $0.085 * *$ & 0.097 & 0.038 & 0.055 & $0.183 * *$ & 0.006 & 0.049 & $0.106^{* *}$ & $0.096^{* * * *}$ & $0.092 * * *$ & $0.886^{* * *}$ & $0.418^{* * *}$ & $0.455^{* * *}$ & 0.017 & 0.120 & 0.114 \\
\hline & $(0.051)$ & $(0.055)$ & $(0.039)$ & $(0.064)$ & (0.043) & $(0.036)$ & $(0.073)$ & $(0.032)$ & $(0.032)$ & $(0.044)$ & $(0.024)$ & $(0.021)$ & $(0.176)$ & $(0.103)$ & $(0.081)$ & $(0.167)$ & $(0.107)$ & $(0.093)$ \\
\hline Clerks & $-0.139 * * *$ & 0.049 & 0.005 & -0.052 & 0.003 & -0.017 & 0.007 & $-0.061^{*}$ & $-0.060^{* *}$ & 0.227 & 0.043 & $0.061^{*}$ & $0.688 * * *$ & 0.075 & $0.105^{* *}$ & -0.159 & 0.030 & -0.001 \\
\hline & $(0.048)$ & $(0.041)$ & $(0.031)$ & $(0.038)$ & $(0.034)$ & $(0.027)$ & $(0.044)$ & $(0.034)$ & $(0.029)$ & $(0.164)$ & $(0.031)$ & $(0.034)$ & $(0.124)$ & $(0.058)$ & $(0.050)$ & $(0.121)$ & $(0.103)$ & (0.081) \\
\hline Service workers and shop and & -0.079 & $-0.114 * *$ & $-0.111 * * *$ & 0.001 & $-0.200 * * *$ & $-0.123 * * *$ & 0.043 & $-0.143 * * *$ & $-0.105 * *$ & -0.011 & $-0.123^{* * *}$ & $-0.088 * * *$ & 0.206 & $-0.375^{* * *}$ & $-0.366^{* * *}$ & -0.016 & $-0.129 *$ & -0.095 \\
\hline market sales workers & $(0.052)$ & $(0.049)$ & $(0.041)$ & $(0.040)$ & $(0.049)$ & $(0.035)$ & $(0.053)$ & $(0.047)$ & $(0.041)$ & $(0.045)$ & $(0.041)$ & $(0.034)$ & $(0.127)$ & $(0.054)$ & $(0.051)$ & $(0.132)$ & $(0.071)$ & $(0.066)$ \\
\hline Craft and related trade workers & -0.113 & $-0.181 * * *$ & $-0.187 * * *$ & -0.039 & $-0.138^{* * * *}$ & $-0.115^{* * * *}$ & -0.106 & $0.176 * *$ & $0.137^{*}$ & $-0.137 *$ *** & $-0.098^{* * *}$ & $-0.107 *$ *** & 0.000 & $-0.323^{* * * *}$ & $-0.288 * * *$ & $-0.408^{* * * *}$ & $-0.200^{* * * *}$ & $-0.227 * * *$ \\
\hline $\begin{array}{l}\text { + skilled workers } \\
\text { Plant and machine operat }\end{array}$ & $(0.203)$ & $(0.045)$ & $(0.040)$ & $(0.057)$ & $(0.032)$ & $(0.029)$ & $(0.143)$ & $(0.081)$ & $(0.076)$ & $(0.051)$ & $(0.024)$ & $(0.022)$ & $(0.000)$ & $(0.052)$ & $(0.052)$ & $(0.090)$ & $(0.053)$ & $(0.048)$ \\
\hline $\begin{array}{l}\text { Plant and machine operators } \\
\text { and assemblers }\end{array}$ & 0.002 & -0.080 & $-0.076^{*}$ & 0.004 & $-0.112^{* * *}$ & $-0.072^{* *}$ & $-0.460^{* * *}$ & 0.105 & 0.050 & -0.103 & $-0.093^{* * *}$ & $-0.100 * * *$ & 0.000 & $-0.182^{2 * * *}$ & $-0.152^{* *}$ & $-0.263^{* * *}$ & $-0.208^{* * *}$ & $-0.230 * * *$ \\
\hline & $(0.077)$ & $(0.049)$ & $(0.045)$ & $(0.050)$ & $(0.033)$ & $(0.029)$ & $(0.125)$ & $(0.152)$ & $(0.137)$ & $(0.123)$ & $(0.034)$ & $(0.032)$ & $(0.000)$ & $(0.065)$ & $(0.066)$ & $(0.087)$ & (0.053) & (0.046) \\
\hline Elementary occupations & $-0.189 * * *$ & $-0.123^{* *}$ & $-0.180 * * *$ & $-0.157 * * *$ & $-0.196 * * *$ & $-0.175^{* * *}$ & $-0.162^{*}$ & $-0.278^{* * *}$ & $-0.269 * * *$ & $-0.294 * * *$ & $-0.121 * *$ & $0.143^{* * * *}$ & $0.210^{*}$ & $-0.286 * * *$ & $-0.266 * * *$ & $-0.473^{* * * *}$ & $-0.389 * * * *$ & $0.396 * * *$ \\
\hline & $(0.061)$ & $(0.052)$ & $(0.043)$ & $(0.041)$ & $(0.054)$ & $(0.037)$ & $(0.097)$ & $(0.058)$ & $(0.050)$ & $(0.086)$ & $(0.047)$ & $(0.043)$ & $(0.115)$ & $(0.057)$ & $(0.051)$ & $(0.096)$ & $(0.065)$ & $(0.056)$ \\
\hline Sector of activity & & & & & & & & & & & & & & & & & & \\
\hline Industry (E+D+F) & $-0.100^{*}$ & 0.001 & -0.029 & $\begin{array}{l}-0.040 \\
-0.078\end{array}$ & 0.037 & $0.035^{*}$ & 0.074 & -0.026 & - -0.047 & $\begin{array}{c}-0.101 \\
-0.063)\end{array}$ & 0.025 & 0.001 & 0.022 & 0.042 & -0.007 & 0.122 & 0.017 & -0.018 \\
\hline & & $(0.036)$ & $(0.027)$ & $(0.078)$ & $(0.033)$ & $(0.021)$ & $(0.067)$ & $(0.028)$ & $(0.031)$ & & $(0.026)$ & $(0.019)$ & & $(0.043)$ & $(0.043)$ & $(0.09$ & & $(0.033)$ \\
\hline Other services $(\mathrm{G}+\mathrm{H}+\mathrm{J}+\mathrm{K})$ & $-0.107^{*}$ & -0.000 & $-0.054^{* *}$ & -0.002 & 0.001 & -0.013 & -0.048 & -0.005 & $-0.043^{*}$ & $0.184^{* * *}$ & 0.008 & -0.00 & 0.032 & 0.037 & 0.001 & -0.207 & 0.088 & 0.023 \\
\hline & $(0.062)$ & $(0.035)$ & $(0.026)$ & $(0.094)$ & $(0.036)$ & $(0.027)$ & $(0.116)$ & $(0.027)$ & $(0.023)$ & $(0.075)$ & $(0.025)$ & $(0.018$ & $(0.086)$ & $(0.043)$ & $(0.041)$ & $(0.229)$ & $(0.059)$ & $(0.049)$ \\
\hline Transportation (I) & $0.077 *$ & 0.129 & 0.059 & 0.064 & $-0.111 * *$ & -0.041 & -0.070 & 0.043 & 0.009 & 0.071 & 0.010 & -0.005 & -0.140 & $-0.166^{*}$ & -0.141 & $0.199 * *$ & $0.156^{* *}$ & $0.147 * * *$ \\
\hline & $(0.040)$ & $(0.080)$ & $(0.053)$ & $(0.056)$ & $(0.044)$ & $(0.031)$ & $(0.076)$ & $(0.056)$ & $(0.052)$ & $(0.129)$ & $(0.029)$ & $(0.026)$ & $(0.104)$ & $(0.097)$ & $(0.097)$ & $(0.079)$ & $(0.076)$ & $(0.055)$ \\
\hline $\begin{array}{l}\text { Public administration and } \\
\text { defense (I) }\end{array}$ & $0.084 * *$ & -0.063 & 0.036 & -0.000 & 0.065 & 0.025 & 0.063 & -0.034 & $0.074 * *$ & -0.015 & 0.076 & $0.099 * * *$ & 0.002 & $0.158^{* * * *}$ & $0.150^{* * * *}$ & -0.057 & -0.110 & -0.048 \\
\hline & $(0.037)$ & $(0.074)$ & $(0.032)$ & $(0.037)$ & $(0.097)$ & $(0.023)$ & $(0.050)$ & $(0.074)$ & $(0.034)$ & $(0.047)$ & $(0.073)$ & $(0.029)$ & $(0.057)$ & $(0.057)$ & $(0.047)$ & $(0.085)$ & $(0.139)$ & $(0.051)$ \\
\hline Other job characteristics & & & & & & & & & & & & & & & & & & \\
\hline Tenure & & -0. & & & $25^{* * *}$ & $0.024 * * *$ & -0.009 & 0.014 & 0.0 & -0.00 & 0.00 & -0.00 & 0.01 & 0.01. & & 0.00 & -0.04 & ;** \\
\hline & & & & & & $(0.009)$ & & & & & & & & & & & & \\
\hline Tenure squared & & & & & & -0.0 & & -0.0 & & & 0.0 & & 0.00 & 0.0 & 0.00 & 0.00 & $0.004^{* * *}$ & $0.004 * * *$ \\
\hline & & & & & & & & & & $(0.001)$ & $(0.00$ & & & & & $(0.0$ & & $(0.001)$ \\
\hline Full time contract & $-0.162^{2 * * * *}$ & & & & & & & & & & $0.09=3$ & & & & 0.01 & 0.2 & 0.16 & $0.207 * *$ \\
\hline & & $(0.0$ & & $(0.1$ & $(0.060)$ & $(0.071)$ & $(0.034)$ & $(0.018)$ & $(0.019)$ & & $(0.046)$ & $(0.038)$ & $(0.048)$ & $(0.069)$ & $(0.061)$ & $(0.161)$ & $(0.125)$ & (0.104) \\
\hline Permanent contract & 0.064 & $0.112^{* * * *}$ & $0.109 * * *$ & 0.036 & 0.022 & 0.033 & -0.064 & 0.155 & 0.099 & $0.232^{* * * *}$ & $0.247 * *$ & $0.223^{* * *}$ & $0.092^{* *}$ & 0.059 & 0.047 & $0.172^{*}$ & 0.052 & $0.061^{*}$ \\
\hline & $(0.042)$ & $(0.038)$ & $(0.030)$ & $(0.045)$ & $(0.030)$ & $(0.026)$ & $(0.055)$ & $(0.137)$ & $(0.104)$ & $(0.064)$ & $(0.113)$ & $(0.063)$ & $(0.037)$ & $(0.044)$ & $(0.029)$ & $(0.091)$ & $(0.036)$ & $(0.034)$ \\
\hline Constant & $2.781 * * *$ & $1.332 * * *$ & $1.656^{* * * *}$ & $2.121 * * *$ & $1.800 * * *$ & $1.835^{* * * *}$ & $3.089 * * *$ & $1.783^{* * * *}$ & $2.193^{* * * *}$ & $2.354^{* * * *}$ & $1.996^{* * * *}$ & $2.109 * * *$ & $3.936^{* * * *}$ & $5.290^{* * * *}$ & $5.196^{* * *}$ & $5.634 * * *$ & $5.451 * * *$ & $5.434^{* * * *}$ \\
\hline & $(0.378)$ & $(0.261)$ & $(0.210)$ & $(0.568)$ & $(0.270)$ & $(0.230)$ & $(0.871)$ & $(0.296)$ & $(0.392)$ & $(0.553)$ & $(0.300)$ & $(0.256)$ & $(0.743)$ & $(0.230)$ & $(0.226)$ & $(0.583)$ & $(0.364)$ & $(0.308)$ \\
\hline Observation & 278 & 430 & 708 & 297 & 635 & 935 & 292 & 531 & 829 & 261 & 840 & $1,1,101$ & 202 & 4497 & 699 & 169 & 704 & 873 \\
\hline $\begin{array}{l}\text { R-squared } \\
\end{array}$ & 0.540 & 0.300 & 0.453 & 0.258 & 0.441 & 0.378 & 0.305 & 0.259 & 0.250 & 0.424 & 0.331 & 0.367 & 0.764 & 0.666 & 0.735 & 0.703 & 0.546 & 0.583 \\
\hline
\end{tabular}

1. Robust weighted standard errors in parenthesis

2. Base categories for dummy variables: Education: less than 2nd stage of secondary education, Legislators, senior officials and managers, Educ. and Health\&\&Social Work, Part time contract, Temporary contract

3. Estimations are run for 1997 
Table A2 (cont.)

\begin{tabular}{|c|c|c|c|c|c|c|c|c|c|c|c|c|}
\hline & \multicolumn{6}{|c|}{ SPAIN } & \multicolumn{6}{|c|}{ UNITED KINGDOM } \\
\hline & \multicolumn{3}{|c|}{ Females } & \multicolumn{3}{|c|}{ Males } & \multicolumn{3}{|c|}{$\begin{array}{r}\text { Females } \\
\end{array}$} & \multicolumn{3}{|c|}{ Males } \\
\hline \multirow{2}{*}{\multicolumn{13}{|c|}{$\begin{array}{l}\text { Demographics } \\
\end{array}$}} \\
\hline & & & & & & & & & & & & \\
\hline \multirow[t]{2}{*}{ Age } & 0.050 & $0.050^{* * *}$ & $0.057 * * *$ & -0.022 & $0.044^{* *}$ & $0.034^{*}$ & 0.037 & $0.044^{* *}$ & $0.045^{* * * *}$ & 0.026 & $0.054^{* * *}$ & $0.053^{* * * *}$ \\
\hline & (0.038) & $(0.023)$ & $(0.020)$ & $(0.037)$ & $(0.020)$ & $(0.018)$ & $(0.024)$ & $(0.020)$ & $(0.015)$ & $(0.024)$ & $(0.016)$ & $(0.014)$ \\
\hline \multirow[t]{2}{*}{ Age squared } & -0.001 & $-0.001 * *$ & $-0.001 * * *$ & 0.000 & $-0.000^{*}$ & -0.000 & -0.000 & $-0.001 * *$ & $-0.001 * * *$ & -0.000 & $-0.001 * * *$ & $-0.001 * *$ \\
\hline & $(0.000)$ & $(0.000)$ & $(0.000)$ & $(0.000)$ & $(0.000)$ & $(0.000)$ & $(0.000)$ & $(0.000)$ & $(0.000)$ & $(0.000)$ & $(0.000)$ & $(0.000)$ \\
\hline \multirow[t]{4}{*}{ Married } & -0.013 & 0.010 & 0.018 & 0.018 & 0.012 & 0.016 & 0.017 & -0.016 & 0.005 & -0.029 & $0.043^{*}$ & 0.027 \\
\hline & $(0.028)$ & $(0.025)$ & $(0.020)$ & $(0.039)$ & $(0.028)$ & $(0.023)$ & $(0.022)$ & $(0.033)$ & $(0.020)$ & $(0.034)$ & $(0.023)$ & $(0.019)$ \\
\hline & 0.016 & 0.035 & 0.021 & 0.004 & -0.025 & -0.018 & $-0.064^{* * *}$ & 0.016 & -0.025 & $0.078 * *$ & $0.035^{*}$ & $0.043 * *$ \\
\hline & $(0.031)$ & $(0.039)$ & $(0.026)$ & $(0.043)$ & $(0.027)$ & $(0.024)$ & $(0.024)$ & $(0.033)$ & $(0.021)$ & $(0.034)$ & $(0.021)$ & $(0.017)$ \\
\hline \multicolumn{13}{|l|}{ Education } \\
\hline \multirow{2}{*}{$\begin{array}{l}\text { Recognised third level education } \\
\text { (ISCED 5-7) }\end{array}$} & 0.082 & $0.140 * * *$ & $0.129 * * *$ & 0.084 & $0.140^{* * * *}$ & $0.126^{* * *}$ & $0.102^{* * *}$ & -0.037 & 0.046 & 0.048 & $0.097 * *$ & $0.096^{* * *}$ \\
\hline & $(0.051)$ & $(0.040)$ & $(0.033)$ & $(0.052)$ & $(0.034)$ & $(0.030)$ & $(0.036)$ & $(0.049)$ & $(0.032)$ & $(0.042)$ & $(0.026)$ & $(0.023)$ \\
\hline Second stage of secondary level & 0.009 & $-0.065^{*}$ & -0.026 & -0.033 & -0.013 & -0.011 & 0.011 & 0.030 & -0.003 & -0.022 & -0.008 & -0.007 \\
\hline education (ISCED 3) & $(0.058)$ & $(0.035)$ & $(0.030)$ & $(0.039)$ & $(0.029)$ & $(0.024)$ & $(0.051)$ & $(0.049)$ & $(0.035)$ & $(0.053)$ & $(0.037)$ & $(0.031)$ \\
\hline \multicolumn{13}{|l|}{ Occupation } \\
\hline Professionals & $\begin{array}{c}0.311^{2 * * *} \\
(0.057)\end{array}$ & $\begin{array}{c}0.243^{* * * *} \\
(0.078)\end{array}$ & $\begin{array}{c}0.2922^{2 * *} \\
(0.053)\end{array}$ & $\begin{array}{c}0.379 * * * * \\
(0.082)\end{array}$ & $\begin{array}{c}0.319^{* * * *} \\
(0.092)\end{array}$ & $\begin{array}{c}0.310^{* * * *} \\
(0.062)\end{array}$ & $\begin{array}{c}0.265^{* * * *} \\
(0.056)\end{array}$ & $\begin{array}{c}0.695^{* * *} \\
(0.107)\end{array}$ & $\begin{array}{c}0.466^{* * *} \\
(0.066)\end{array}$ & $\begin{array}{c}0.249 * * * \\
(0.051)\end{array}$ & $\begin{array}{c}0.311^{* * * *} \\
(0.046)\end{array}$ & $\begin{aligned} 0.279 * * * \\
(0.034)\end{aligned}$ \\
\hline \multirow{2}{*}{$\begin{array}{l}\text { Technicians and associate } \\
\text { professionals }\end{array}$} & $0.151^{*}$ & 0.070 & 0.053 & 0.074 & 0.034 & 0.062 & $0.145 * * *$ & $0.246 * * *$ & $0.255^{* * * *}$ & $0.128^{*}$ & $0.244^{* * *}$ & $0.191^{* * *}$ \\
\hline & (0.087) & $(0.065)$ & $(0.054)$ & $(0.072)$ & $(0.055)$ & $(0.047)$ & $(0.051)$ & $(0.066)$ & $(0.043)$ & $(0.066)$ & $(0.049)$ & $(0.038)$ \\
\hline \multirow[t]{2}{*}{ Clerks } & $-0.125 * *$ & $-0.107 *$ & $-0.132 * * *$ & $-0.218^{* * * *}$ & 0.083 & -0.001 & -0.057 & 0.009 & 0.026 & -0.115 & -0.150 & $-0.120 * *$ \\
\hline & $(0.063)$ & $(0.048)$ & $(0.040)$ & $(0.062)$ & $(0.070)$ & $(0.055)$ & $(0.059)$ & $(0.043)$ & $(0.037)$ & $(0.072)$ & $(0.101)$ & $(0.059)$ \\
\hline Service workers and shop and & $-0.137^{* *}$ & $-0.234 * * *$ & $-0.215 * * *$ & -0.010 & $-0.312^{2 * * *}$ & $-0.219^{* * *}$ & -0.078 & $-0.308^{* * * *}$ & $-0.139 * * *$ & 0.009 & $-0.249_{* * * *}$ & $-0.156^{* * *}$ \\
\hline market sales w & $(0.064)$ & $(0.052)$ & $(0.043)$ & $(0.060)$ & $(0.061)$ & $(0.047)$ & $(0.049)$ & $(0.064)$ & $(0.047)$ & $(0.064)$ & $(0.075)$ & $(0.054)$ \\
\hline Craft and related trade workers & $-0.231 * * *$ & $-0.203 * * *$ & $-0.182^{* * *}$ & -0.140 & $-0.144^{* * *}$ & $-0.151^{* * *}$ & & -0.104 & -0.117 & -0.060 & -0.047 & $-0.054^{*}$ \\
\hline + skilled workers & $(0.077)$ & $(0.074)$ & $(0.060)$ & $(0.144)$ & $(0.035)$ & $(0.035)$ & & $(0.139)$ & $(0.131)$ & $(0.083)$ & $(0.035)$ & $(0.032)$ \\
\hline \multirow{2}{*}{$\begin{array}{l}\text { Plant and machine operators } \\
\text { and assemblers }\end{array}$} & 0.000 & -0.080 & -0.055 & -0.147 & $-0.218^{* * *}$ & $-0.223^{* * *}$ & & $-0.369 * * *$ & $-0.374^{* * *}$ & $-0.318^{* * *}$ & $-0.104^{* * *}$ & $-0.132^{* * *}$ \\
\hline & $(0.000)$ & $(0.081)$ & $(0.072)$ & $(0.145)$ & $(0.046)$ & $(0.046)$ & & $(0.082)$ & $(0.085)$ & $(0.090)$ & $(0.038)$ & (0.034) \\
\hline \multirow[t]{2}{*}{ Elementary occupations } & $-0.424 * * *$ & $-0.300 * * * *$ & $-0.338 * * *$ & $-0.218 * *$ & $-0.230 * * * *$ & $-0.217 * * *$ & $-0.412^{* * *}$ & $-0.311^{2 * * *}$ & $-0.320 * * * *$ & $-0.332^{* *}$ & $-0.311^{2 * * *}$ & $-0.316^{* * *}$ \\
\hline & $(0.079)$ & $(0.079)$ & $(0.063)$ & $(0.109)$ & $(0.061)$ & $(0.051)$ & $(0.101)$ & $(0.092)$ & $(0.065)$ & $(0.139)$ & $(0.059)$ & $(0.054)$ \\
\hline Sector of activity & & & & & & & & & & & & \\
\hline Industry $(\mathrm{E}+\mathrm{D}+\mathrm{F})$ & 0.159 & -0.069 & -0.083 & 0.052 & $0.064^{*}$ & $0.054^{*}$ & $0.550^{* * *}$ & -0.024 & 0.054 & 0.000 & 0.048 & 0.026 \\
\hline & $(0.119)$ & $(0.069)$ & $(0.056)$ & $(0.136)$ & $(0.034)$ & $(0.031)$ & $(0.058)$ & $(0.057)$ & $(0.057)$ & $(0.070)$ & $(0.031)$ & $(0.024)$ \\
\hline Other services $(\mathrm{G}+\mathrm{H}+\mathrm{J}+\mathrm{K})$ & -0.441 & -0.073 & $-0.110^{* *}$ & $0.237 * *$ & -0.022 & $-0.065^{*}$ & $-0.194^{*}$ & $-0.109 * *$ & $-0.090 * *$ & 0.108 & 0.005 & -0.019 \\
\hline & $(0.288)$ & $(0.056)$ & $(0.043)$ & $(0.118)$ & $(0.050)$ & $(0.039)$ & $(0.099)$ & $(0.049)$ & $(0.041)$ & $(0.070)$ & $(0.035)$ & $(0.034)$ \\
\hline Transportation (I) & 0.094 & $0.237^{*}$ & 0.142 & 0.060 & $-0.098^{*}$ & -0.039 & $-0.308^{* * * *}$ & -0.002 & -0.059 & -0.056 & -0.020 & -0.025 \\
\hline & $(0.116)$ & $(0.139)$ & $(0.099)$ & (0.088) & $(0.058)$ & $(0.049)$ & $(0.087)$ & $(0.074)$ & $(0.078)$ & $(0.077)$ & $(0.049)$ & $(0.040)$ \\
\hline $\begin{array}{l}\text { Public administration and } \\
\text { defense }(L)\end{array}$ & 0.084 & 0.000 & 0.069 & $-0.150 * * *$ & -0.026 & 0.029 & $0.109 *$ & $0.256^{* * *}$ & $0.170^{* * *}$ & $0.075^{*}$ & $0.138^{* *}$ & $0.148^{* * *}$ \\
\hline & $(0.088)$ & $(0.000)$ & $(0.051)$ & $(0.053)$ & $(0.063)$ & $(0.035)$ & $(0.059)$ & $(0.090)$ & $(0.048)$ & $(0.042)$ & $(0.054)$ & $(0.037)$ \\
\hline Other job characteristics & & & & & & & & & & & & \\
\hline Tenure & -0.011 & 0.005 & 0.009 & $0.067 * * *$ & 0.014 & 0.023 & 0.025 & 0.000 & 0.020 & 0.020 & -0.003 & 0.001 \\
\hline & & & $(0.016)$ & $(0.022)$ & $(0.017)$ & $(0.015)$ & $(0.017)$ & $(0.023)$ & $(0.015)$ & $(0.021)$ & $(0.014)$ & $(0.012)$ \\
\hline Tenure squared & 0.001 & 0.001 & 0.000 & $-0.000^{* * *}$ & -0.000 & -0.001 & $-0.002^{*}$ & 0.000 & -0.002 & -0.001 & 0.001 & 0.000 \\
\hline & $(0.002)$ & $(0.002)$ & $(0.001)$ & $(0.002)$ & $(0.001)$ & $(0.001)$ & $(0.001)$ & $(0.002)$ & $(0.001)$ & $(0.002)$ & $(0.001)$ & $(0.001)$ \\
\hline Full time contract & 0.015 & -0.041 & -0.015 & 0.000 & -0.009 & -0.012 & & & & & & \\
\hline Permanent contract & $\begin{array}{c}(0.074) \\
0.090 * * *\end{array}$ & $\begin{array}{l}(0.029) \\
0.109 * * *\end{array}$ & $\begin{array}{l}(0.027) \\
0.105 * *\end{array}$ & $\begin{array}{l}(0.000) \\
0.116^{* * *}\end{array}$ & $\begin{array}{l}(0.044) \\
0.110^{* * * *}\end{array}$ & $\begin{array}{l}(0.040) \\
0.120 * * *\end{array}$ & $0.166^{*}$ & & $0.177^{*}$ & & & \\
\hline & $(0.032)$ & $(0.037)$ & $(0.030)$ & $(0.041)$ & $(0.025)$ & $(0.023)$ & $(0.095)$ & & (0.098) & & & \\
\hline Constant & $5.551^{1 * * * *}$ & $5.499 * * * *$ & $5.349 \% * * *$ & 7.081 1\%*\% & $5.598 * * * *$ & $5.796^{* * * *}$ & 0.625 & $0.657 *$ & 0.346 & $1.096^{* *}$ & 0.454 & $0.501 *$ \\
\hline & $(0.688)$ & $(0.448)$ & $(0.383)$ & $(0.695)$ & $(0.380)$ & $(0.342)$ & $(0.498)$ & $(0.378)$ & $(0.301)$ & $(0.490)$ & $(0.303)$ & $(0.270)$ \\
\hline Observations & 198 & 333 & 534 & 202 & 618 & 826 & 217 & 296 & 513 & 154 & 545 & 699 \\
\hline R-squared & 0.603 & 0.535 & 0.623 & 0.493 & 0.476 & 0.469 & 0.469 & 0.335 & 0.370 & 0.545 & 0.417 & 0.422 \\
\hline
\end{tabular}

1. Robust weighted standard errors in parenthesis

on: less than 2 nd stage of secondary education, Legislators, senior officials and managers, Educ. and Health\&\&Social Work, Part time contract, Temporary contract 3. Estimations are run for 1997 
Table A3. Transitions between non-working, working in the public sector and working in the private sector (absolute numbers)

\begin{tabular}{|c|c|c|c|c|c|c|c|c|c|}
\hline & \multicolumn{3}{|c|}{ Belgium } & \multicolumn{3}{|c|}{ Denmark } & \multicolumn{3}{|c|}{ France } \\
\hline & All & Females & Males & All & Females & Males & All & Females & Males \\
\hline \multicolumn{10}{|l|}{ Transitions Private sector } \\
\hline Private-Private & 6617,00 & 2628,00 & 3989,00 & 8736,00 & 3032,00 & 5704,00 & 20205,00 & 7933,00 & 12272,00 \\
\hline Private-Public & 199,00 & 107,00 & 92,00 & 202,00 & 108,00 & 94,00 & 108,00 & 45,00 & 63,00 \\
\hline Private - Unemployed & 170,00 & 87,00 & 83,00 & 213,00 & 107,00 & 106,00 & 704,00 & 339,00 & 365,00 \\
\hline Private - Inactive & 201,00 & 124,00 & 77,00 & 228,00 & 136,00 & 92,00 & 941,00 & 567,00 & 374,00 \\
\hline Total & 7187,00 & 2946,00 & 4241,00 & 9379,00 & 3383,00 & 5996,00 & 21958,00 & 8884,00 & 13074,00 \\
\hline \multicolumn{10}{|l|}{ Transitions Public sector } \\
\hline Public-Public & 3431,00 & 1758,00 & 1673,00 & 5885,00 & 3867,00 & 2018,00 & 10431,00 & 5666,00 & 4765,00 \\
\hline Public-Private & 209,00 & 117,00 & 92,00 & 220,00 & 111,00 & 109,00 & 133,00 & 67,00 & 66,00 \\
\hline Public - Unemployed & 30,00 & 23,00 & 7,00 & 111,00 & 75,00 & 36,00 & 193,00 & 121,00 & 72,00 \\
\hline Public - Inactive & 75,00 & 59,00 & 16,00 & 213,00 & 168,00 & 45,00 & 368,00 & 240,00 & 128,00 \\
\hline Total & 3745,00 & 1957,00 & 1788,00 & 6429,00 & 4221,00 & 2208,00 & 11125,00 & 6094,00 & 5031,00 \\
\hline \multicolumn{10}{|l|}{ Transitions Unemployed } \\
\hline Unemployed - Private & 243,00 & 126,00 & 117,00 & 277,00 & 117,00 & 160,00 & 903,00 & 452,00 & 451,00 \\
\hline Unemployed - Public & 91,00 & 61,00 & 30,00 & 165,00 & 122,00 & 43,00 & 249,00 & 161,00 & 88,00 \\
\hline Total & 334,00 & 187,00 & 147,00 & 442,00 & 239,00 & 203,00 & 1152,00 & 613,00 & 539,00 \\
\hline \multicolumn{10}{|l|}{ Transitions Inactive } \\
\hline Inactive - Private & 239,00 & 125,00 & 114,00 & 185,00 & 112,00 & 73,00 & 1009,00 & 548,00 & 461,00 \\
\hline Inactive - Public & 75,00 & 45,00 & 30,00 & 229,00 & 179,00 & 50,00 & 370,00 & 250,00 & 120,00 \\
\hline Total & 314,00 & 170,00 & 144,00 & 414,00 & 291,00 & 123,00 & 1379,00 & 798,00 & 581,00 \\
\hline
\end{tabular}

\begin{tabular}{|c|c|c|c|c|c|c|c|c|c|}
\hline & \multicolumn{3}{|c|}{ Germany } & \multicolumn{3}{|c|}{ Greece } & \multicolumn{3}{|c|}{ Ireland } \\
\hline & All & Females & Males & All & Females & Males & All & Females & Males \\
\hline \multicolumn{10}{|l|}{ Transitions Private sector } \\
\hline Private-Private & 25592,00 & 9531,00 & 16061,00 & 14764,00 & 4716,00 & 10048,00 & 9647,00 & 3594,00 & 6053,00 \\
\hline Private-Public & 487,00 & 264,00 & 223,00 & 310,00 & 130,00 & 180,00 & 271,00 & 139,00 & 132,00 \\
\hline Private - Unemployed & 798,00 & 324,00 & 474,00 & 587,00 & 259,00 & 328,00 & 285,00 & 114,00 & 171,00 \\
\hline Private - Inactive & 995,00 & 518,00 & 477,00 & 575,00 & 419,00 & 156,00 & 457,00 & 312,00 & 145,00 \\
\hline Total & 27872,00 & 10637,00 & 17235,00 & 16236,00 & 5524,00 & 10712,00 & 10660,00 & 4159,00 & 6501,00 \\
\hline \multicolumn{10}{|l|}{ Transitions Public sector } \\
\hline Public-Public & 9103,00 & 5195,00 & 3908,00 & 5563,00 & 2149,00 & 3414,00 & 4173,00 & 1835,00 & 2338,00 \\
\hline Public-Private & 631,00 & 331,00 & 300,00 & 269,00 & 94,00 & 175,00 & 304,00 & 141,00 & 163,00 \\
\hline Public - Unemployed & 189,00 & 128,00 & 61,00 & 69,00 & 35,00 & 34,00 & 64,00 & 26,00 & 38,00 \\
\hline Public - Inactive & 340,00 & 227,00 & 113,00 & 117,00 & 48,00 & 69,00 & 109,00 & 63,00 & 46,00 \\
\hline Total & 10263,00 & 5881,00 & 4382,00 & 6018,00 & 2326,00 & 3692,00 & 4650,00 & 2065,00 & 2585,00 \\
\hline \multicolumn{10}{|l|}{ Transitions Unemployed/Inactive } \\
\hline Unemployed - Private & 871,00 & 380,00 & 491,00 & 793,00 & 362,00 & 431,00 & 426,00 & 158,00 & 268,00 \\
\hline Unemployed - Public & 223,00 & 150,00 & 73,00 & 110,00 & 60,00 & 50,00 & 101,00 & 44,00 & 57,00 \\
\hline Total & 1094,00 & 530,00 & 564,00 & 903,00 & 422,00 & 481,00 & 527,00 & 202,00 & 325,00 \\
\hline \multicolumn{10}{|l|}{ Transitions Inactive } \\
\hline Inactive - Private & 607,00 & 328,00 & 279,00 & 652,00 & 439,00 & 213,00 & 609,00 & 398,00 & 211,00 \\
\hline Inactive - Public & 201,00 & 146,00 & 55,00 & 88,00 & 55,00 & 33,00 & 149,00 & 118,00 & 31,00 \\
\hline Total & 808,00 & 474,00 & 334,00 & 740,00 & 494,00 & 246,00 & 758,00 & 516,00 & 242,00 \\
\hline
\end{tabular}


Table A3 (cont.) Transitions between non-working, working in the public sector and working in the private sector (absolute numbers)

\begin{tabular}{|c|c|c|c|c|c|c|c|c|c|}
\hline & \multicolumn{3}{|c|}{ Italy } & \multicolumn{3}{|c|}{ Netherlands } & \multicolumn{3}{|c|}{ Portugal } \\
\hline & All & Females & Males & All & Females & Males & All & Females & Males \\
\hline \multicolumn{10}{|l|}{ Transitions Private sector } \\
\hline Private-Private & 25149,00 & 8124,00 & 17025,00 & 17844,00 & 6036,00 & 11808,00 & 20291,00 & 7675,00 & 12616,00 \\
\hline Private-Public & 458,00 & 173,00 & 285,00 & 717,00 & 432,00 & 285,00 & 564,00 & 286,00 & 278,00 \\
\hline Private - Unemployed & 763,00 & 311,00 & 452,00 & 168,00 & 83,00 & 85,00 & 374,00 & 187,00 & 187,00 \\
\hline Private - Inactive & 753,00 & 445,00 & 308,00 & 502,00 & 301,00 & 201,00 & 608,00 & 409,00 & 199,00 \\
\hline Total & 27123,00 & 9053,00 & 18070,00 & 19231,00 & 6852,00 & 12379,00 & 21837,00 & 8557,00 & 13280,00 \\
\hline \multicolumn{10}{|l|}{ Transitions Public sector } \\
\hline Public-Public & 10738,00 & 4912,00 & 5826,00 & 6433,00 & 3141,00 & 3292,00 & 5923,00 & 3189,00 & 2734,00 \\
\hline Public-Private & 463,00 & 153,00 & 310,00 & 759,00 & 439,00 & 320,00 & 618,00 & 277,00 & 341,00 \\
\hline Public - Unemployed & 125,00 & 64,00 & 61,00 & 49,00 & 23,00 & 26,00 & 75,00 & 47,00 & 28,00 \\
\hline Public - Inactive & 279,00 & 104,00 & 175,00 & 125,00 & 88,00 & 37,00 & 161,00 & 87,00 & 74,00 \\
\hline Total & 11605,00 & 5233,00 & 6372,00 & 7366,00 & 3691,00 & 3675,00 & 6777,00 & 3600,00 & 3177,00 \\
\hline \multicolumn{10}{|l|}{ Transitions Unemployed/Inactive } \\
\hline Unemployed - Private & 1060,00 & 415,00 & 645,00 & 306,00 & 161,00 & 145,00 & 534,00 & 280,00 & 254,00 \\
\hline Unemployed - Public & 244,00 & 133,00 & 111,00 & 79,00 & 50,00 & 29,00 & 114,00 & 58,00 & 56,00 \\
\hline Total & 1304,00 & 548,00 & 756,00 & 385,00 & 211,00 & 174,00 & 648,00 & 338,00 & 310,00 \\
\hline \multicolumn{10}{|l|}{ Transitions Inactive } \\
\hline Inactive - Private & 609,00 & 338,00 & 271,00 & 526,00 & 301,00 & 225,00 & 716,00 & 441,00 & 275,00 \\
\hline Inactive - Public & 151,00 & 84,00 & 67,00 & 124,00 & 95,00 & 29,00 & 206,00 & 141,00 & 65,00 \\
\hline Total & 3368,00 & 1518,00 & 338,00 & 650,00 & 396,00 & 254,00 & 922,00 & 582,00 & 340,00 \\
\hline
\end{tabular}

\begin{tabular}{|c|c|c|c|c|c|c|c|c|c|}
\hline & \multicolumn{3}{|c|}{ Spain } & \multicolumn{3}{|c|}{ Sweden $^{1}$} & \multicolumn{3}{|c|}{ United Kingdom } \\
\hline & All & Females & Males & All & Females & Males & All & Females & Males \\
\hline \multicolumn{10}{|l|}{ Transitions Private sector } \\
\hline Private-Private & 20503,00 & 6214,00 & 14289,00 & 2174,00 & 826,00 & 1348,00 & 20299,00 & 8194,00 & 12105,00 \\
\hline Private-Public & 446,00 & 194,00 & 252,00 & 1320,00 & 972,00 & 348,00 & 434,00 & 277,00 & 157,00 \\
\hline Private - Unemployed & 1311,00 & 528,00 & 783,00 & 394,00 & 202,00 & 192,00 & 397,00 & 168,00 & 229,00 \\
\hline Private - Inactive & 791,00 & 498,00 & 293,00 & 404,00 & 251,00 & 153,00 & 1207,00 & 806,00 & 401,00 \\
\hline Total & 23051,00 & 7434,00 & 15617,00 & 4292,00 & 2251,00 & 2041,00 & 22337,00 & 9445,00 & 12892,00 \\
\hline \multicolumn{10}{|l|}{ Transitions Public sector } \\
\hline Public-Public & 5556,00 & 2458,00 & 3098,00 & 706,00 & 515,00 & 191,00 & 6303,00 & 4078,00 & 2225,00 \\
\hline Public-Private & 480,00 & 192,00 & 288,00 & 1374,00 & 514,00 & 860,00 & 432,00 & 246,00 & 186,00 \\
\hline Public - Unemployed & 175,00 & 92,00 & 83,00 & 220,00 & 119,00 & 101,00 & 52,00 & 32,00 & 20,00 \\
\hline Public - Inactive & 119,00 & 63,00 & 56,00 & 310,00 & 192,00 & 118,00 & 322,00 & 238,00 & 84,00 \\
\hline Total & 6330,00 & 2805,00 & 3525,00 & 2610,00 & 1340,00 & 1270,00 & 7109,00 & 4594,00 & 2515,00 \\
\hline \multicolumn{10}{|l|}{ Transitions Unemployed/Inactive } \\
\hline Unemployed - Private & 1654,00 & 845,00 & 1109,00 & 493,00 & 191,00 & 302,00 & 496,00 & 160,00 & 336,00 \\
\hline Unemployed - Public & 280,00 & 166,00 & 114,00 & 273,00 & 207,00 & 66,00 & 65,00 & 31,00 & 34,00 \\
\hline Total & 1934,00 & 1011,00 & 1223,00 & 766,00 & 398,00 & 368,00 & 561,00 & 191,00 & 370,00 \\
\hline \multicolumn{10}{|l|}{ Transitions Inactive } \\
\hline Inactive - Private & 911,00 & 566,00 & 345,00 & 432,00 & 160,00 & 272,00 & 1154,00 & 776,00 & 378,00 \\
\hline Inactive - Public & 149,00 & 98,00 & 51,00 & 239,00 & 171,00 & 68,00 & 324,00 & 261,00 & 63,00 \\
\hline Total & 1060,00 & 664,00 & 396,00 & 671,00 & 331,00 & 340,00 & 1478,00 & 1037,00 & 441,00 \\
\hline
\end{tabular}

Notes: 1. For Sweden there are only four waves (1997-2001) 